\title{
Ontwikkelingen op de arbeidsmarkt in 2001
}

Citation for published version (APA):

Vlasblom, J. D., Diephuis, B. J., Dijksman, S., \& Marey, P. S. (2000). Ontwikkelingen op de arbeidsmarkt in 2001. Researchcentrum voor Onderwijs en Arbeidsmarkt, Faculteit der Economische Wetenschappen. ROA Reports No. $10 \mathrm{https} / / / \mathrm{doi}$. org/10.26481/umarep.2000010

Document status and date:

Published: 01/01/2000

DOI:

10.26481/umarep.2000010

Document Version:

Publisher's PDF, also known as Version of record

\section{Please check the document version of this publication:}

- A submitted manuscript is the version of the article upon submission and before peer-review. There can be important differences between the submitted version and the official published version of record.

People interested in the research are advised to contact the author for the final version of the publication, or visit the DOI to the publisher's website.

- The final author version and the galley proof are versions of the publication after peer review.

- The final published version features the final layout of the paper including the volume, issue and page numbers.

Link to publication

\footnotetext{
General rights rights.

- You may freely distribute the URL identifying the publication in the public portal. please follow below link for the End User Agreement:

www.umlib.nl/taverne-license

Take down policy

If you believe that this document breaches copyright please contact us at:

repository@maastrichtuniversity.nl

providing details and we will investigate your claim.
}

Copyright and moral rights for the publications made accessible in the public portal are retained by the authors and/or other copyright owners and it is a condition of accessing publications that users recognise and abide by the legal requirements associated with these

- Users may download and print one copy of any publication from the public portal for the purpose of private study or research.

- You may not further distribute the material or use it for any profit-making activity or commercial gain

If the publication is distributed under the terms of Article $25 \mathrm{fa}$ of the Dutch Copyright Act, indicated by the "Taverne" license above, 
Ontwikkelingen op de arbeidsmarkt in 2001

ROA-R-2000/10

\begin{abstract}
J.D. Vlasblom
B.J. Diephuis

S. Dijksman

Ph.S. Marey
\end{abstract}

Researchcentrum voor Onderwijs en Arbeidsmarkt

Faculteit der Economische Wetenschappen en Bedrijfskunde Universiteit Maastricht

Maastricht, oktober 2000 
Niets uit deze uitgave mag worden verveelvoudigd en/of openbaar gemaakt door middel van druk, fotokopie, microfilm, of op welke wijze ook, zonder voorafgaande schriftelijke toestemming van de directeur van het Researchcentrum voor Onderwijs en Arbeidsmarkt. In geval van overname van het datamateriaal moet telkens als bron worden vermeld 'Researchcentrum voor Onderwijs en Arbeidsmarkt' of 'ROA'. Van publicaties waarin gebruik wordt gemaakt van gegevens uit dit rapport ontvangen wij gaarne een exemplaar.

In dit onderzoek is gebruik gemaakt van Sociaal-Economisch Panel (SEP)-gegevens, jaargangen 1994, 1995 en 1996 van het CBS, die via het Wetenschappelijk Statistisch Agentschap zijn verkregen.

Hoewel de grootst mogelijke zorg is besteed aan de inhoud van dit rapport, kan het ROA in generlei opzicht verantwoordelijkheid op zich nemen voor eventuele onvolledigheden of onjuistheden.

Dit rapport maakt deel uit van het Project Onderwijs Arbeidsmarkt (POA). Dit project wordt gefinancierd door het Ministerie van Onderwijs, Cultuur en Wetenschappen, Arbeidsvoorziening Basisdiensten, het LDC Expertisecentrum voor Loopbaanvraagstukken en het Ministerie van Landbouw, Natuurbeheer en Visserij.

Onze dank gaat uit naar de leden van de begeleidingscommissie voor hun deskundige en intensieve begeleiding van het project. Deze commissie bestaat uit de volgende leden: prof.dr. H. Ganzeboom (voorzitter; Universiteit Utrecht), drs. A. Bouman (Arbeidsvoorziening Basisdiensten), dhr. H. Daale (Haagse Hogeschool), dr.ir. F.Y. Dijkstra (Ministerie van Onderwijs, Cultuur en Wetenschappen), drs. A. Gast (Centraal Bureau voor de Statistiek), drs. E.F.H.A. Janissen (LDC, Expertisecentrum voor Loopbaanstukken), dr. P.W.C. Koning (Centraal Planbureau), ir. J.E.M. Lint (Ministerie van Landbouw, Natuurbeheer en Visserij), drs. S.B. Meerbeek (Ministerie van Economische Zaken), drs. M.G.K. Einerhand (Ministerie van Sociale Zaken en Werkgelegenheid), dr. H.H. van der Velde (Ministerie van Onderwijs, Cultuur en Wetenschappen), dhr. E. van der Groep (Ministerie van Onderwijs, Cultuur en Wetenschappen), drs. J.P. Vosse (Organisatie voor Strategisch Arbeidsmarktonderzoek), mevr. C. van der Rest (COLO) en dr. P.M. Veen (Ministerie van Onderwijs, Cultuur en Wetenschappen).

ISBN 90-5321-296-5

Sec00156/JDV 


\section{Inhoud}

Bladzijde

1 Inleiding 1

2 Het arbeidsmarktmodel en de prognosemethodiek 7

2.1 Inleiding 7

2.2 Het stromenmodel voor de arbeidsmarkt $\quad 7$

2.3 Methodiek voor de prognoses 9

$\begin{array}{ll}2.4 & \text { Aanpassingen voor de regionale prognoses } \\ & 13\end{array}$

2.5 De bepaling van knelpunten op de arbeidsmarkt 17

$\begin{array}{ll}2.6 & \text { Samenvatting } \\ & 20\end{array}$

3 Stromen op de arbeidsmarkt 23

3.1 Inleiding 23

3.2 Uitstroom van de arbeidsmarkt 23

$\begin{array}{ll}3.3 & \text { Baanmobiliteit op de arbeidsmarkt } \\ 3.4 & 29\end{array}$

3.4 Instroom op de arbeidsmarkt 34

3.5 De relatieve positie van aanbieders op de arbeidsmarkt 40

3.6 Samenvatting 43

4 Verwachte ontwikkelingen op de korte termijn 49

$\begin{array}{ll}4.1 & \text { Inleiding } \\ 4.2 & 49\end{array}$

4.2 Uitbreidingsvraag 49

4.3 Bruto vervangingsvraag $\quad 55$

4.4 Instroom van baanwisselaars $\quad 59$

4.5 Instroom van schoolverlaters op de arbeidsmarkt 61

4.6 Instroom van herintreders op de arbeidsmarkt 64

$\begin{array}{ll}\text { 4.7 Spanning op de arbeidsmarkt } & 68\end{array}$

4.8 Oplossingen voor de verwachte knelpunten 72

$\begin{array}{ll}4.9 \text { Samenvatting } & 76\end{array}$

5 Regionale ontwikkelingen op de arbeidsmarkt 81

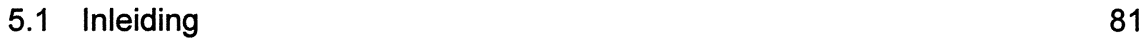

5.2 Werkgelegenheid per regio 82

$\begin{array}{ll}5.3 & \text { Uitbreidingsvraag per regio } \\ 5.4 & 85\end{array}$

$\begin{array}{ll}5.4 & \text { Bruto vervangingsvraag per regio } \\ 5.5 & 89\end{array}$

5.5 Totale vraag per regio $\quad 91$

$\begin{array}{ll}5.6 & \text { Aanbod per regio } \\ 5.7 & 93\end{array}$

$\begin{array}{lr}5.7 \text { Knelpunten per regio } & 97\end{array}$

$\begin{array}{ll}5.8 \text { Samenvatting } & 100\end{array}$

6 Samenvatting en voorstellen voor ontwikkeling 103

$\begin{array}{ll}6.1 \text { Inleiding } & 103\end{array}$

$\begin{array}{ll}6.2 \text { Samenvatting } & 103\end{array}$

6.3 Uitbreiding van de informatievoorziening 112

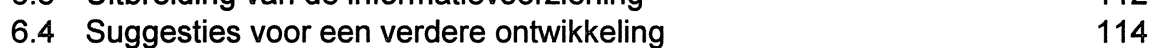

$\begin{array}{ll}\text { Literatuur } & 117\end{array}$ 



\section{Inleiding}

Sinds 1986 wordt er bij het ROA gewerkt aan het opstellen van arbeidsmarktprognoses voor de middellange termijn (zie o.a. Van Eijs en De Grip, 1998). Deze prognoses worden opgemaakt voor een periode van 5 jaar, en worden eens in de twee jaar herzien. Op deze manier zijn er altijd recente prognoses beschikbaar voor de ontwikkelingen op de arbeidsmarkt op de middellange termijn. In toenemende mate is er in de tijd die sindsdien verstreken is echter behoefte ontstaan aan prognoses met een kortere horizon. Tegelijk met deze gegroeide belangstelling voor prognoses voor de ontwikkelingen op korte termijn, is er tevens een verschuiving zichtbaar van de inhoudelijke vraagstelling. In de prognoses voor de middellange termijn zijn de schoolverlaters degenen die de meeste belangstelling hebben, maar er is in toenemende mate behoefte aan informatie over andere groepen op de arbeidsmarkt, zoals bijvoorbeeld werklozen en herintreders.

De toenemende belangstelling voor prognoses voor de korte termijn moet voor een deel gezocht worden in veranderende omstandigheden op de arbeidsmarkt. In de ruime arbeidsmarkt van de 80 -er en de eerste helft van de 90 -er jaren hadden de prognoses vooral tot doel om de transparantie van de arbeidsmarkt voor studiekiezers te vergroten. De prognoses geven daarom een beeld van de verwachte arbeidsmarktpositie voor schoolverlaters op het moment dat zij hun opleiding afgerond hebben. Dit leidt dus tot de keus van de prognosetermijn van ongeveer vijf jaar (de gemiddelde studieduur). Op het ogenblik is er echter in toenemende mate sprake van een krappe arbeidsmarkt, hetgeen betekent dat vooral de werkgevers problemen hebben of krijgen met het vinden van voldoende goed opgeleid personeel. Het gevolg hiervan is dat men in toenemende mate gaat zoeken onder andere groepen op de arbeidsmarkt dan alleen de schoolverlaters, zoals bijvoorbeeld de werklozen en de herintreders. Om- en bijscholing van dit deel van de (potentiële) beroepsbevolking dat doorgaans niet onmiddellijk inzetbaar is, kan een effectief middel zijn om de discrepanties tussen vraag en aanbod, en daarmee de knelpunten in de personeelsvoorziening, te verminderen. Het type scholingsprogramma's dat door bv. de Arbeidsvoorzieningsorganisatie gehanteerd wordt om knelpunten te voorkomen of te verminderen is echter meestal niet gericht op de middellange, maar juist op de korte termijn (dat wil zeggen: één, hooguit twee jaar vooruit). De huidige prognosetermijn van vijf jaar genereert derhalve niet de informatie die vereist is voor dit gebruiksdoel. Prognoses van de vraag- en aanbodontwikkelingen op de arbeidsmarkt op de korte termijn en de daaruit resulterende discrepanties op de arbeidsmarkt vullen dit hiaat in de aanwezige arbeidsmarktinformatie.

Bij dit type kortdurende om- en bijscholing gaat het overigens niet alleen om de scholing van werkzoekenden of niet-participerenden. Ook scholing van werkenden kan een belangrijke rol spelen bij het verminderen van de knelpunten in de personeelsvoorziening (zie ROA, 1997). Lang niet alle banen kunnen vervuld worden door 'nieuwkomers' op de arbeidsmarkt. Voor de vervulling van sommige functies zijn mensen nodig met werkervaring. Door werkenden te scholen, kan de doorstroming 
naar dergelijke functies verbeterd worden, zodat enerzijds mogelijke knelpunten in de personeelsvoorziening voor de hogere functies verminderd kunnen worden, terwijl aan de andere kant functies op een lager niveau beschikbaar komen voor de 'nieuwkomers' op de arbeidsmarkt. Een dergelijk model van doorschuiven van vacatures naar lagere niveaus of andere richtingen wordt ook wel aangeduid met de term 'cascademodel' (zie o.a. Hofman e.a., 1991). De informatie over de op korte termijn verwachte ontwikkelingen op de arbeidsmarkt is hierdoor ook van belang voor de loopbaanoriëntatie van werkenden.

Tegelijk met de toenemende belangstelling voor de korte termijn is er ook een verschuiving ontstaan in de specifieke informatiebehoefte. De prognoses voor de middellange termijn zijn helemaal gericht op netto ontwikkelingen in vraag en aanbod op de arbeidsmarkt. De informatiebehoefte verschuift echter steeds meer naar de onderliggende bruto bewegingen. Het groeiende bewustzijn dat problemen van vraag en aanbod opgelost zouden kunnen worden door beleid op heel specifieke doelgroepen te richten, maakt het noodzakelijk dat er informatie over deze groepen aanwezig is. Voordat namelijk duidelijk is of voor bepaalde beroepen instroombevorderende of uitstroomremmende maatregelen effectief zijn, moet bekend zijn hoe groot de bruto in- en uitstroom voor deze beroepen is. Daarnaast wordt, vanuit het aspect van de voorlichting, loopbaanoriëntatie gericht op werkzoekenden en werkenden steeds belangrijker. Ook dit vereist meer inzicht in de bewegingen op de arbeidsmarkt die gegeven iemands beroep en/of opleiding te verwachten zijn. Met andere woorden, vanuit een voorlichtingsperspectief is er behoefte aan een beter inzicht in de bruto stromen op de arbeidsmarkt. Deze informatie over bruto stromen kan niet geconstrueerd worden op basis van de methodiek die door het ROA voor de prognoses voor de middellange termijn gehanteerd wordt.

Tot slot neemt ook de behoefte aan regionale informatie toe. Verschillende bedrijfssectoren zijn niet gelijk verdeeld over de regio's, maar ook blijkt dat werkzoekenden niet altijd even mobiel zijn tussen de regio's. Dit kan er toe leiden dat er op landelijk niveau sprake is van een evenwicht tussen vraag en aanbod, terwijl in feite in een deel van het land sprake is van tekorten, en in een ander deel sprake is van overschotten. Ook wordt het beleid voor een belangrijk deel regionaal bepaald. Voor de Arbeidsvoorzieningsorganisatie in het bijzonder vervullen de arbeidsmarktprognoses voor de korte termijn niet alleen een rol bij de scholingsplanning en het bemiddelingsbeleid, maar daarnaast ook voor de algehele beleidsplanningscyclus, de taakstellingen voor de arbeidsvoorzieningsgebieden, de vacaturewerving, sectorstudies, etc. (zie De Grip, 1993).

De bovengenoemde overwegingen leiden tot de conclusie dat de huidige informatievoorziening tekort schiet op een drietal aspecten: de langere prognosetermijn, de gerichtheid op uitsluitend schoolverlaters, en het ontbreken van een regionale verbijzondering van de prognoses. Omdat het tegemoetkomen aan deze 'tekortkomingen' nogal wat implicaties heeft, is ervoor gekozen - in plaats van de bestaande methodiek voor de prognoses voor de middellange termijn aan te passen - een geheel nieuwe prognosemethodiek te ontwikkelen. 
Deze nieuwe methodiek is gepresenteerd in een verkennende studie die afgelopen jaar door het ROA is uitgevoerd (Vlasblom en Diephuis, 2000). Er is daarbij gekozen voor een aanpak die sterk afwijkt van de voor de middellange termijn gehanteerde methodiek. $\mathrm{Er}$ is namelijk in navolging van eerdere door het ROA verrichte studies (Borghans e.a., 1998a en De Grip en Vlasblom, 1999) gekozen voor een model dat bruto stromen beschrijft in plaats van netto stromen. Dit model gaat uit van veranderingen op individueel niveau en is hierdoor veel beter in staat uitspraken te doen over wie er van beroep of baan verandert. Het is op basis van een dergelijk model dus makkelijker om uitspraken te doen over onderlinge concurrentieverhoudingen van de verschillende groepen aanbieders op de arbeidsmarkt. Binnen een dergelijk model is het in principe ook mogelijk een relatie te leggen tussen de werkzoekendenen vacaturecijfers, de mobiliteit en de onderliggende vraag- en aanbodontwikkelingen op de arbeidsmarkt. Hierdoor kan een indicatie verkregen worden van de lengte van de zogenaamde vacatureketens waardoor er een relatie gelegd kan worden tussen het aantal vacatures en aantal baanopeningen voor nieuwkomers. Dit is met name belangrijk als de prognoses bedoeld zijn voor andere doelgroepen dan de studiekiezers in het initieel onderwijs.

Door de bruto stromen te aggregeren kan - net zoals in het arbeidsmarktmodel voor de middellange termijn het geval is - per opleiding of beroep een discrepantie tussen vraag en aanbod bepaald worden. Hierdoor is duidelijk op welke plaatsen op korte termijn een probleem verwacht wordt. Op deze manier kan een beeld verkregen worden welke scholing aangeboden zou kunnen worden om deze knelpunten te verminderen (zie De Grip e.a., 1999a). Hierbij kan gedacht worden aan de scholingsactiviteiten zoals deze worden ontplooid door Arbeidsvoorziening, de voorlichting die door het LDC expertisecentrum voor loopbaanvraagstukken aan werkzoekenden wordt gegeven, en de verschillende contractactiviteiten in het BVE-veld. De prognoses zijn dus van minder belang voor scholieren die aan het begin van hun schoolloopbaan staan. De duur van een initiele (beroeps)opleiding is immers langer dan de gehanteerde prognoseperiode. Deze groep kan zich derhalve beter richten op toekomstige arbeidsmarktperspectieven op basis van de prognoses voor de middellange termijn. Dit geldt ook voor onderwijsinstellingen en hun financiers die overwegen nieuwe opleidingen te beginnen of reeds bestaande opleidingen aan willen passen.

De prognoses zijn gebaseerd op een aantal databronnen. De gegevens voor de werkgelegenheidsontwikkeling zijn gebaseerd op het Centraal Economisch Plan 2000 van het Centraal Planbureau. De prognoses voor de instroom van schoolverlaters op de arbeidsmarkt hebben als uitgangspunt de Referentieraming 1999 van het Ministerie van Onderwijs, Cultuur en Wetenschappen. Voor de regionale verbijzonderingen is gebruik gemaakt van de Regionale Arbeidsmarktprognoses 20002005 van Arbeidsvoorziening. Gegevens over het arbeidsmarktgedrag van schoolverlaters zijn ontleend aan het Schoolverlaters Informatiesysteem van het ROA. Het merendeel van de gebruikte data is echter afkomstig van het Centraal Bureau voor de Statistiek. Ten eerste zijn de jaren 1997 en 1998 uit de Enquête Beroepsbevolking gebruikt. Daarnaast zijn de jaren 1994 tot en met 1996 van het Sociaal 
Economisch Panel gebruikt. Recentere gegevens waren ten tijde van de samenstelling van dit rapport nog niet beschikbaar.

De in dit rapport gepresenteerde prognoses hebben betrekking op het komende kalenderjaar, het jaar 2001. De gehanteerde indelingen van opleiding en beroep sluiten zo goed mogelijk aan bij de indelingen die in De arbeidsmarkt naar opleiding en beroep tot 2004 (ROA, 1999a) gehanteerd zijn. Vanwege de kortere voorspelhorizon, en de daarmee samenhangende onzekerheidsmarges, zullen echter in dit rapport veel prognoses op een hoger aggregatieniveau gepresenteerd worden. Een deel van de prognoses worden echter in de statistische bijlage van dit rapport ook op het lage aggregatieniveau van 97 opleidingstypen en 121 beroepsgroepen getoond.

De indeling van dit rapport is als volgt. In hoofdstuk 2 wordt een beschrijving gegeven van de methodologische aspecten van het gehanteerde arbeidsmarktmodel en de prognoses. De beschrijving van de gehanteerde prognosemethodiek is - deels - gebaseerd op een eerder verschenen werkdocument (Vlasblom en Diephuis, 2000) waarin een uitgebreide toelichting wordt gegeven. Omdat de methodiek in hoge mate gebaseerd is op een modellering van de bruto stromen op de arbeidsmarkt, wordt in hoofdstuk 3 een overzicht gegeven van de in dit rapport onderscheiden bruto stromen op de arbeidsmarkt. De invalshoek in dit hoofdstuk is dus die van de individuele overgangen die mensen op de arbeidsmarkt maken. Door dit illustratieve hoofdstuk wordt de lezer zich bewust van de processen die zich op de arbeidsmarkt voordoen, en op welke wijze knelpunten kunnen ontstaan. Het inzicht in de processen die spelen vereenvoudigt enerzijds de interpretatie van de prognoses zoals die in hoofdstuk 4 en 5 getoond worden, terwijl het anderzijds ook een indruk geeft waar de oplossingen voor de optredende knelpunten gezocht kunnen worden. Met het geven van deze informatie gaat het huidige rapport dus verder dan bijvoorbeeld $D e$ arbeidsmarkt naar opleiding en beroep dat zich beperkt tot het presenteren en bespreken van prognoses.

Vervolgens worden in hoofdstuk 4 de landelijke arbeidsmarktprognoses gepresenteerd. De prognoses in dit hoofdstuk worden per opleiding en per beroep gepresenteerd. Er zijn hierbij twee verschillen met de prognoses voor de middellange termijn. Ten eerste worden in dit rapport zowel vraag als aanbod per beroep gepresenteerd. Ten tweede wordt, zoals hierboven al werd opgemerkt, het merendeel van de prognoses op een (relatief) hoog aggregatieniveau getoond.

In hoofdstuk 5 worden de regionale prognoses gepresenteerd. De methodiek voor de prognoses en verbijzonderingen wordt beschreven in hoofdstuk 2. Zoals daar aangegeven wordt, komen de prognoses voor een deel tot stand als afzonderlijke prognoses voor de diverse regio's, voor een ander deel betreft het verbijzonderingen van landelijke resultaten. Met name deze regionale prognoses moeten vanwege het lage aggregatieniveau met de nodige voorzichtigheid betracht worden: de aantallen werkenden waarop ze betrekking hebben overschrijdt in een aantal gevallen nauwelijks de door het CBS gehanteerde publicatiegrenzen. Ook zijn er bij het opstellen van de regionale prognoses enkele vrij sterke aannamen nodig die van belang zijn voor de interpretatie van de resultaten. 
Hoofdstuk 6 ten slotte presenteert de samenvatting van het rapport en de conclusies. Daarnaast gaat hoofdstuk 6 uitgebreid in op de vraag op welke manieren de geboden informatie uitgebreid kan worden, en op welke punten de nu gehanteerde methodiek in de komende jaren aangepast kan worden ten einde de kwaliteit van de geboden informatie in de toekomst te verbeteren. 


\section{Het arbeidsmarktmodel en de prognosemethodiek}

\subsection{Inleiding}

In dit hoofdstuk wordt een beschrijving gegeven van het gehanteerde arbeidsmarktmodel. Hieruit vloeit vervolgens de methodiek voort die gebruikt is om de prognoses te maken die in hoofdstuk 4 en 5 gepresenteerd worden. Dit hoofdstuk is voor een zeer groot deel gebaseerd op een eerder verschenen werkdocument: Methodiek voor korte-termijn arbeidsmarktprognoses op basis van een stromenmodel (Vlasblom en Diephuis, 2000). In paragraaf 2.2 wordt ingegaan op het arbeidsmarktmodel. Dit model is gebaseerd op een beschrijving van de bruto stromen op de arbeidsmarkt. Door deze stromen op individueel niveau te koppelen aan kenmerken als leeftijd, geslacht, opleiding en beroep kan inzicht verkregen worden welke veranderingen er op korte termijn op de arbeidsmarkt te verwachten zijn. De verwachte veranderingen kunnen vervolgens gebruikt worden om tot vraagen aanbodprognoses per opleiding en beroep te komen. De aanpak die hiervoor wordt gebruikt staat beschreven in paragraaf 2.3. In hoofdstuk 5 worden regionale prognoses gepresenteerd. Deze zijn in principe door dezelfde methodiek tot stand gekomen. Er waren echter wel extra aannamen en verbijzonderingen noodzakelijk voor deze regionale prognoses. Deze worden beschreven in paragraaf 2.4. Paragraaf 2.5 gaat ten slotte in op de manier waarop de vraag- en aanbodprognoses gebruikt worden om tot een indicatie van de situatie op de arbeidsmarkt te komen, en hoe deze arbeidsmarktindicator getypeerd zal worden. Ten slotte wordt in paragraaf 2.6 een samenvatting van de belangrijkste punten uit het hoofdstuk gegeven.

\subsection{Het stromenmodel voor de arbeidsmarkt}

Bij het maken van de arbeidsmarktprognoses is uitgegaan van een stroomcijferaanpak. In tegenstelling tot de methodiek voor de middellange termijn wordt hierbij niet uitgegaan van een netto maar van een bruto stromenbenadering; er worden prognoses gemaakt van de bruto stromen van en naar de arbeidsmarkt in de nabije toekomst. Deze benadering heeft als voordeel dat er meer inzicht verkregen wordt in de bewegingen die plaatsvinden op de arbeidsmarkt, want daar waar in de nettostromenaanpak iemand die zijn baan verlaat gecompenseerd wordt door zijn opvolger (een netto stroom van nul) wordt in de huidige aanpak expliciet een uitstroom van 1 en een instroom van 1 onderscheiden. Daarnaast verschaft deze aanpak ook meer inzicht in de mate waarin deze bewegingen afhangen van bv. opleidingsniveau en opleidingsrichting van de betrokkenen, omdat de gegevens over de veranderingen afkomstig zijn uit een bestand waar individuele veranderingen gerelateerd kunnen worden aan persoonlijke kenmerken.

De onderscheiden mogelijke bewegingen op de arbeidsmarkt staan geïllustreerd in figuur 2.1. De (potentiële) beroepsbevolking valt in principe in te delen in drie categorieën: de werkenden, de niet-participerenden (waaronder ook de werklozen gerekend worden) en de scholieren. De prognoses richten zich op de ontwikkelingen binnen de groep werkenden. Vanuit deze groep vindt uitstroom plaats naar de andere twee groepen, er vindt baanmobiliteit plaats binnen de groep werkenden, of 
men verdwijnt - bv. door pensioen - buiten de potentiële beroepsbevolking. Aan de andere kant vindt er in deze groep instroom plaats, uit de groep scholieren (aangeduid als schoolverlaters), uit de groep niet-participerenden (aangeduid als herintreders), maar ook door baanmobiliteit (aangeduid als baanwisselaars). In deze bruto-stromenbenadering is het dus mogelijk om de totale uitstroom op te splitsen in vier groepen, en om de totale instroom op te splitsen in drie groepen.

Als het aantal werkenden in een bepaald beroep of opleiding gelijk blijft, zal de totale uitstroom gecompenseerd moeten worden door nieuwe arbeidskrachten van elders. Deze vraag naar nieuwe arbeidskrachten noemen we de bruto vervangingsvraag. Opgemerkt moet worden dat deze bruto vervangingsvraag afwijkt van de netto vervangingsvraag zoals die in de arbeidsmarktprognoses voor de middellange termijn bepaald wordt, omdat daar de baanmobiliteit en het arbeidsaanbod van herintreders niet expliciet meegeteld wordt als onderdeel van de vraag. In het model voor de middellange termijn wordt de vervangingsvraag bepaald als de vraag naar nieuwkomers op de arbeidsmarkt, dat wil zeggen: als de totale uitstroom minus de instroom uit de herintreders en de instroom uit de niet-participerenden. Door de nadere opsplitsing van de in- en uitstroom is het bruto-stromenmodel in staat om gedetailleerdere informatie over bewegingen op de arbeidsmarkt te verstrekken dan het netto-stromenmodel dat voor de arbeidsmarktprognoses voor de middellange termijn gehanteerd wordt.

Figuur 2.1

Een stroomschema van de arbeidsmarkt

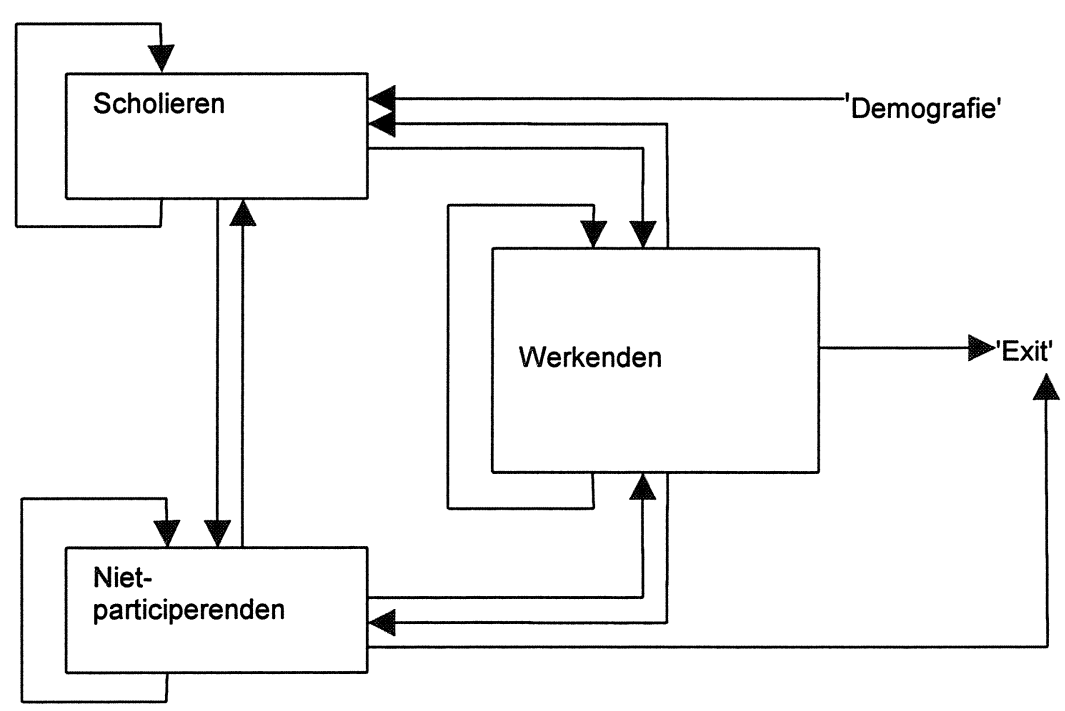




\subsection{Methodiek voor de prognoses}

De bewegingen zoals die in figuur 2.1 geïllustreerd worden, liggen ten grondslag aan het model dat gehanteerd wordt voor het opstellen van de prognoses. De structuur van het prognosemodel wordt weergegeven in figuur 2.2. Een grootheid die van belang is voor de vraagzijde van de arbeidsmarkt is de uitbreidingsvraag, die de ontwikkeling weergeeft van de werkgelegenheid in een bepaalde beroepssector of voor een bepaald opleidingstype. In termen van figuur 2.1 geeft de uitbreidingsvraag dus aan wat de gewenste omvang van de groep werkenden is. De prognoses van de uitbreidingsvraag zijn gebaseerd op de werkgelegenheidsprognoses voor bedrijfssectoren van het Centraal Planbureau. Vanwege de nadruk op de korte termijn wordt hierbij uitgegaan van de arbeidsmarktprognoses voor de korte termijn afkomstig uit het Centraal Economisch Plan 2000.

De prognose voor de uitbreidingsvraag wordt gebaseerd op het uitbreidingsvraagmodel zoals dat ontwikkeld is voor de prognoses voor de middellange termijn. Net zoals bij de arbeidsmarktprognoses voor de middellange termijn worden dus ook de arbeidsmarktprognoses voor de korte termijn aangepast voor verschuivingen in de beroepenstructuur binnen de onderscheiden bedrijfssectoren. Hierdoor kan er rekening gehouden worden met het feit dat binnen een bedrijfssector bepaalde beroepsgroepen zich sneller ontwikkelen dan andere. Dit zijn echter bij uitstek ontwikkelingen die plaatsvinden over een langere termijn, het effect hiervan op de korte termijn zal dus relatief klein zijn. Ditzelfde geldt voor het optreden van verschuivingen in de opleidingenstructuur van beroepsgroepen. Hoewel zowel de prognoses voor de middellange als die voor de korte termijn gebaseerd worden op hetzelfde model, verschillen deze prognoses aanzienlijk omdat ze gebaseerd zijn op verschillende 'basisscenario's'. De uitbreidingsvraagprognoses voor de middellange termijn zijn gebaseerd op het 'behoedzame scenario' uit de middellange-termijn prognoses van het CPB, terwijl de uitbreidingsvraagprognoses voor de korte termijn gebaseerd zijn op het Centraal Economisch Plan 2000. Dit verschil in uitgangspunten maakt de prognoses uit De arbeidsmarkt naar opleiding en beroep tot 2004 onvergelijkbaar met de prognoses die in dit rapport getoond worden.

Naast uitbreidingsvraag is er op de arbeidsmarkt sprake van uitstroom door - al dan niet vervroegde - pensionering, arbeidsongeschiktheid, tijdelijke terugtreding van de arbeidsmarkt, beroepsmobiliteit, e.d. Bij gelijkblijvende werkgelegenheid binnen een bedrijf zal een werkgever deze uitstroom dus moeten vervangen door nieuwe werknemers. Deze uitstroom zal dus leiden tot vraag naar nieuw personeel, aangeduid met de term 'bruto vervangingsvraag'. Een krimpende werkgelegenheid leidt niet tot een lagere vervangingsvraag, zelfs niet als de uitstroom gebruikt wordt om deze krimp te effectueren. De reden hiervoor is dat een krimpende werkgelegenheid verrekend wordt door een negatieve uitbreidingsvraag. De uitbreidingsvraag en de bruto vervangingsvraag tezamen vormen de totale vraag naar arbeidskrachten op de arbeidsmarkt. In de totale vraag wordt dus wel rekening gehouden met het feit dat een werkgelegenheidskrimp bereikt wordt door een uitstroom die hoger is dan de instroom van nieuw personeel. Merk op dat dit een verschil is met de methodiek die voor de prognoses voor de middellange termijn gehanteerd wordt: daar is de totale 
vraag naar nieuwkomers de som van de netto vervangingsvraag en de uitbreidingsvraag (zolang deze positief is).

\section{Figuur 2.2}

Globale opzet van het prognosemodel

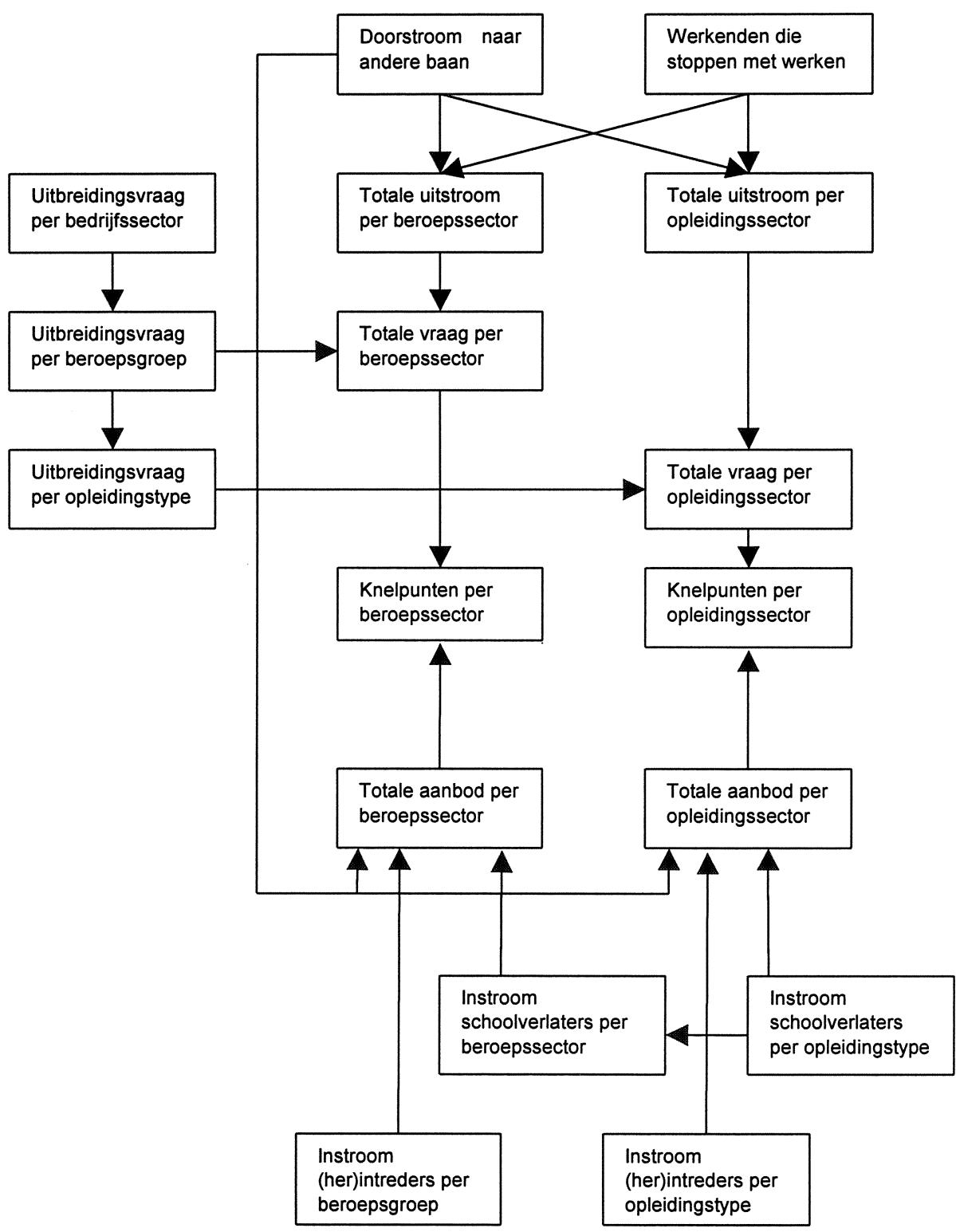

De prognose voor de vervangingsvraag wordt gebaseerd op het stromenmodel voor de arbeidsmarkt. Er wordt hierbij gebruik gemaakt van een tweestaps-procedure. In de eerste stap wordt er gebruik gemaakt van het Sociaal-Economisch Panel (SEP), 
een databestand van het Centraal Bureau voor de Statistiek. Het SEP is een bestand met een relatief klein aantal waarnemingen, maar waarin wel veel individuele kenmerken opgenomen zijn. Omdat de steekproef ieder jaar in principe uit dezelfde personen bestaat zijn deze gegevens beschikbaar voor een reeks van jaren. Dit maakt het mogelijk om op individueel (micro) niveau de ontwikkelingen na te gaan. Op basis van deze gegevens wordt een model geschat waarmee de relatie tussen de diverse stromen en de individuele kenmerken gelegd kan worden. De basis voor het model wordt gevormd door een aantal multinomiale logitmodellen (zie bv. Maddala, 1983) waarmee de overgangskansen van individuen worden verklaard. Dit model levert een prognose op voor de verwachte mobiliteit van mensen gegeven hun kenmerken. In de tweede stap wordt er gebruik gemaakt van de Enquête Beroepsbevolking (EBB) van het CBS. Dit is een bestand met een groot aantal waarnemingen dat 'opgewogen' is tot de omvang van de beroepsbevolking. Op basis van dit bestand wordt nagegaan hoe de samenstelling is van de (potentiële) beroepsbevolking naar arbeidsmarktpositie en achtergrondgegevens zoals leeftijd, geslacht en opleiding. Door deze gegevens te combineren met de in de eerste stap geschatte mobiliteitsprognoses kan een schatting gemaakt worden van de mobiliteit in het komende jaar. Deze tweestapsmethode moet worden gebruikt omdat enerzijds het SEP te klein is om er een betrouwbare beschrijving van de (potentiële) beroepsbevolking mee te geven en anderzijds omdat het niet mogelijk is op basis van de EBB individuele gegevens (m.n. veranderingen in de arbeidsmarktpositie) voor een reeks van jaren na te gaan. Voor de details van het model wordt verwezen naar het werkdocument over het stroommodel (Vlasblom en Diephuis, 2000).

Tegenover de totale vraag naar werknemers staat het verwachte aanbod van werkzoekenden. Zoals gezegd vindt deze instroom plaats vanuit drie groepen: allereerst de werknemers die van baan wisselen (baanmobiliteit), vervolgens de instroom van schoolverlaters uit het initieel en het niet-initieel onderwijs, en de derde 'instroomcategorie' wordt gevormd door de verwachte instroom van herintreders. Deze laatste groep bestaat uit de instroom van werklozen die een baan gevonden hebben en van niet-actieven die weer gaan werken. De informatie over de baanwisselaars en de (her)intrede vanuit de niet-participerenden vormt een van de grote verschillen met het middellange-termijn model dat uitsluitend uitgaat van aanbod van schoolverlaters en kortdurig werklozen. Ook voor deze twee nieuwe instroomcategorieën wordt de prognose gebaseerd op het geschatte stromenmodel, in combinatie met de gegevens over de populatieopbouw uit de EBB.

De instroom van de schoolverlaters zal (mede) worden gebaseerd op hetzelfde model dat voor de arbeidsmarktprognoses voor de middellange termijn gehanteerd wordt. De prognoses van de instroom van schoolverlaters op de arbeidsmarkt gebruiken dus, net zoals de meest recente uitgave van De arbeidsmarkt naar opleiding en beroep, als uitgangspunt de Referentieraming van het Ministerie van Onderwijs, Cultuur en Wetenschappen met betrekking tot de verwachte uitstroom uit het initiële onderwijs. Door het ROA zijn deze prognoses nader verbijzonderd en aangevuld met prognoses van de doorstroom naar het niet-reguliere onderwijs. 
Het moet nogmaals opgemerkt worden dat zowel de vraag als het aanbod in deze prognoses ruimer gedefinieerd zijn dan in de arbeidsmarktprognoses voor de middellange termijn zoals die in De arbeidsmarkt naar opleiding en beroep gepresenteerd worden. Naar de kant van de werkzoekenden mogen ze dus ook ruimer geïnterpreteerd worden: het gaat nu niet meer om perspectieven voor alleen schoolverlaters, maar ook om perspectieven van werkzoekenden met een andere achtergrond. Door de andere methodiek kunnen de uitkomsten per opleiding of beroep afwijken van de uitkomsten uit de arbeidsmarktprognoses voor de middellange termijn. Een tweede opmerking ten aanzien van de vergelijkbaarheid tussen de arbeidsmarktprognoses voor de middellange termijn en de arbeidsmarktprognoses voor de korte termijn betreft de indicator die de knelpunten per beroep aangeeft. De hiervoor in dit rapport gehanteerde methodiek wijkt namelijk sterk af van de methodiek die in de meest recente uitgave van De arbeidsmarkt naar opleiding en beroep gehanteerd wordt. In de methodiek voor de middellange termijn zijn de knelpunten naar beroep afgeleid van die naar opleiding. In de huidige methodiek worden ze afzonderlijk bepaald. Hierdoor zijn de verschillen tussen beide rapporten voor wat betreft de knelpunten naar beroep groter dan de verschillen voor wat betreft de knelpunten naar opleiding. Overigens is het zeer lastig om knelpunten naar beroep te voorspellen, en moeten de uitkomsten uit beide methodieken als indicatief beschouwd worden.

De prognoses worden in eerste instantie opgesteld voor een relatief hoog aggregatieniveau van 11 beroepssectoren en 17 opleidingssectoren, maar daar waar mogelijk worden de prognoses gegeven voor in totaal 121 beroepsgroepen en 97 opleidingstypen. Beide aggregatieniveaus bestrijken de volle breedte van de arbeidsmarkt. In veel gevallen wordt in dit rapport naast een getalsmatige indicatie ook een kwalitatieve typering gegeven van de prognose. Het doel van deze kwalitatieve typering is tweeledig. Allereerst vereenvoudigt de typering de interpretatie van de cijfers. Anderzijds wordt door deze kwalitatieve typering rekening gehouden met de onzekerheidsmarges waarmee het opstellen van prognoses gepaard gaat. Er worden in alle gevallen relatieve typeringen gegeven. Dat wil zeggen dat alle percentages in een tabel gerelateerd worden aan de andere percentages in dezelfde tabel. Met uitzondering van de knelpuntindicator die in paragraaf 2.5 gepresenteerd zal worden, zullen alle prognoses worden getypeerd met behulp van de zogenaamde kwantielenmethode. Deze methode wordt ook mede gebruikt bij de prognoses voor de middellange termijn (zie Wieling e.a., 1990). Hierbij worden de grenzen zo gekozen, dat ca. 10 procent van het totaal aantal percentages getypeerd wordt als 'zeer laag', ca. 20 procent als 'laag', ca. 40 procent als 'gemiddeld', ca. $20 \%$ als hoog, en ca. $10 \%$ als 'zeer hoog'. De typeringsgrenzen en de typeringen worden bepaald op basis van de niet-afgeronde percentages. Daarna worden de percentages afgerond. Dit kan er in een aantal gevallen toe leiden dat eenzelfde afgeronde waarde twee verschillende typeringen krijgt.

Er zijn bij de gehanteerde typeringen dus twee verschillen ten opzichte van de methode die bij de prognoses voor de middellange termijn gebruikt wordt. Het eerste verschil is dat de typeringgrenzen en dus de typeringen bepaald worden aan de hand van de niet-afgeronde percentages, terwijl voor de middellange termijn de typering 
bepaald wordt aan de hand van de niet-afgeronde percentages. Dit wordt gedaan omdat voor de huidige prognoses de prognosetermijn veel korter is, en daarmee de spreiding in de percentages ook veel kleiner is. Door eerst af te ronden, en daarna pas te typeren, zou veel van de informatie over de aanwezige spreiding verloren gaan. Een typering kan dan in een aantal gevallen zinloos worden, omdat voor sommige items vrijwel alle percentages als 'gemiddeld' getypeerd zouden worden. Een tweede verschil komt voort uit het feit dat voor het bepalen van de typeringsgrenzen bij de prognoses voor de middellange termijn in veel gevallen een 'mix' gebruikt wordt van de kwantielen- en de symmetrische methode'. In dit rapport wordt echter uitsluitend van de kwantielenmethode gebruik gemaakt. De reden hiervoor is dat het gebruiken van één methode een veel doorzichtiger beeld geeft, en dat bij de gehanteerde aggregatieniveaus de 'informatiewinst' van de veel bewerkelijkere methode zeer gering is.

\subsection{Aanpassingen voor de regionale prognoses}

Bij het maken van regionale prognoses is het de vraag hoe groot de regio's moeten zijn, en dus ook hoeveel regio's er onderscheiden moeten worden. Aan de ene kant is het een voordeel als er weinig regio's zijn. Ten eerste zijn dit dan grote regio's, hetgeen de kwaliteit van de beschikbare data beter maakt, en ten tweede vormt het vóórkomen van mobiliteit tussen de regio's een kleiner probleem naarmate de regio's groter zijn. Aan de andere kant zijn de gebruikers gebaat bij een zo klein mogelijke regio, mits de cijfers over die regio nog betrouwbaar zijn. $\mathrm{Er}$ is besloten om een zestal regio's te hanteren die in schema 2.1 gegeven worden. Hierbij is aansluiting gezocht met de bestaande indeling in 18 RBA-regio's en de indeling in zes grotere regio's die door Arbeidsvoorziening gehanteerd wordt. Bij deze zes regio's lijken de data nog van voldoende kwaliteit, is de regionale mobiliteit waarschijnlijk geen grote verstorende factor, en zijn de resultaten nog voldoende regiospecifiek om bruikbaar te zijn. Voor deze zes regio's zijn vervolgens prognoses opgesteld voor de afzonderlijke componenten die ook bij de landelijke prognoses gepresenteerd zijn. Dus achtereenvolgens: uitbreidingsvraag, vervangingsvraag, aanbod van schoolverlaters, baanwisselaars en herintreders. In het resterende deel van deze paragraaf staat kort aangegeven hoe deze prognoses tot stand gekomen zijn.

1. Bij de symmetrische methode worden de typeringsgrenzen bepaald door symmetrische intervallen rond het gemiddelde percentage te nemen. De breedte van deze intervallen is bepaald aan de hand van de standaardfout van de percentages. Het gemiddelde en de standaardfout van de percentages worden bepaald over alle opleidingstypen en beroepsgroepen. Omdat voor het nauwkeurig bepalen van een standaardfout relatief veel waarnemingen nodig zijn, leek deze methode voor dit rapport waar resultaten op een relatief hoog aggregatieniveau bepaald worden niet zinvol. 
Schema 2.1

De gehanteerde regio-indeling bij de regionale arbeidsmarktprognoses

\begin{tabular}{|c|c|c|}
\hline Regionaam & Afkorting & RBA-gebieden \\
\hline Noord-Nederland & $\mathrm{N}$ & Groningen, Friesland, Drenthe \\
\hline Oost-Nederland & 0 & Overijssel, IJssel-Veluwe, Gelderland \\
\hline Noordwest-Nederland & NW & Flevoland, Noord-Holland Noord, Zuidelijk Noord-Holland \\
\hline Middenwest-Nederland & MW & Midden-Nederland, Rijnstreek, Haaglanden \\
\hline Zuidwest-Nederland & ZW & Rijnmond, Zeeland, Midden- en West-Brabant \\
\hline Zuidoost-Nederland & ZO & Noordoost-Brabant, Zuidoost-Brabant, Limburg \\
\hline
\end{tabular}

Bron: Arbeidsvoorziening

\section{Regionale uitbreidingsvraag}

In opdracht van Arbeidsvoorziening maakt TNO/Inro regionale arbeidsmarktprognoses voor het aantal werkenden per sector per RBA-gebied. De door TNO/Inro gehanteerde sectorindeling is echter niet geheel gelijk aan de door het ROA gehanteerde indeling. Daarom geldt dat deze prognoses niet zonder meer gebruikt kunnen worden als basis voor regionale uitbreidingsvraagprognoses. Ze kunnen echter wel gebruikt worden om de landelijke prognoses zoals die in hoofdstuk 3 gepresenteerd zullen worden regionaal te verbijzonderen. De gebruikte methode is daarbij als volgt: De regionale prognoses van Arbeidsvoorziening worden teruggebracht tot 6 regio's en de door het ROA onderscheiden economische sectoren. Vervolgens wordt op basis van deze cijfers het landelijk groeipercentage berekend en de regionale afwijkingen daarvan. Deze regionale afwijkingen van het landelijk gemiddelde worden vervolgens gebruikt om op basis van de cijfers voor de landelijke (procentuele) uitbreidingsvraag per sector de regionale cijfers af te leiden. Dit levert voor de afzonderlijke regio's de uitbreidingsvraag per sector op. Deze wordt vervolgens gebruikt als input voor het beroepen- en opleidingenmodel om uitbreidingsvraag per beroep en opleiding te bepalen. Hierbij wordt dus aangenomen dat alle verschuivingen in vraag naar bepaalde beroepen binnen sectoren en een verschuiving van de gevraagde opleidingen (upgrading) in alle regio's in gelijke mate optreedt.

Er doet zich vanwege deze extra verdeelstap een probleem voor als de regionale cijfers met de landelijke cijfers vergeleken worden. Door de 'omweg' die nodig is, ontstaan afrondfouten in de aantallen, en daardoor ook in de gerapporteerde percentages. Hierdoor tellen de cijfers van de zes regio's niet geheel op tot de landelijke cijfers. De afrondfouten zijn vrij beperkt bij de uitbreidingsvraag naar beroepssector (en zijn daar nauwelijks terug te vinden), maar voor de uitbreidingsvraag naar opleidingssector zijn de afrondfouten relatief groot. Het feit dat de afrondfouten hier zo veel groter zijn, komt doordat de opleidingsclassificatie in SEP niet een-op-een aansluit bij de ROA-classificatie die voor de tabellen gehanteerd wordt. Het gevolg van deze afrondfouten is dat voor een aantal - met name kleinere - opleidingssectoren het landelijk gemiddeld percentage sterk afwijkt van de gemiddelde uitbreidingsvraag over de regio's. Omdat de uitbreidingsvraag slechts een relatief klein deel 
van de totale vraag vormt, vormen deze afrondfouten geen groot probleem als het gaat om het vergelijken van de knelpunten in de diverse regio's.

\section{Regionale vervangingsvraag, baanmobiliteit en aanbod van herintreders}

Net zoals dit voor de landelijke prognoses gebeurt, worden voor de regionale prognoses de bruto vervangingsvraag, de baanmobiliteit en het verwachte aanbod van herintreders op basis van het stromenmodel bepaald. Het model wordt hiervoor niet opnieuw geschat, omdat de daarvoor benodigde data - met name die van het SEP - ontbreken. In plaats daarvan worden de op de landelijke data geschatte verbanden tussen uitstroom enerzijds en persoonlijke kenmerken anderzijds gebruikt. Deze geschatte relaties worden vervolgens toegepast op een EBB-bestand dat de samenstelling van de regionale populatie weergeeft. De verschillen tussen regio's die in de prognoses zichtbaar zijn, zijn dus gebaseerd op verschillen tussen de regio's met betrekking tot de samenstelling van de bevolking, de sectoren die in die regio's vertegenwoordigd zijn, en de persoonlijke kenmerken van de werkenden in die regio. Ze worden niet veroorzaakt door verschil in gedrag tussen de regio's. Dit heeft wel tot gevolg dat de verschillen tussen de regio's mogelijk onderschat worden, omdat het zo kan zijn dat in een regio met veel economische activiteit (bv. de randstad) het mobiliteitsgedrag van mensen op de arbeidsmarkt - hun bereidheid te gaan werken of de mogelijkheden om van baan te wisselen - heel anders is dan in regio's waar veel minder activiteit is (bv. Groningen).

Naast de aanname dat gedrag niet verschilt tussen de regio's is er een tweede aanname nodig die vérstrekkende gevolgen kan hebben voor de prognoses. Deze aanname betreft de mate waarin regionale mobiliteit plaatsvindt. Het kan namelijk zo zijn dat mensen die in de ene regio wonen en werken tegelijkertijd met een verandering van arbeidsmarktpositie ook van woonregio veranderen. In dat geval zou zo iemand als uitstroom in de ene regio tellen, maar in een andere regio als aanbod meegeteld moeten worden. Dat wordt nu niet gedaan: er wordt verondersteld dat de regio's 'gesloten' gebieden zijn. Met andere woorden: er vindt geen structurele verschuiving van de bevolking plaats naar bv. de gebieden met veel economische activiteit.

\section{Aanbod van schoolverlaters}

Bij het maken van regionale prognoses is de regionale verbijzondering van schoolverlaters een van de lastigste. Voor de andere groepen op de arbeidsmarkt kan redelijkerwijs nog verondersteld worden dat ze regionaal gebonden zijn, maar voor schoolverlaters is die regionale gebondenheid veel minder. Met name voor de hogere opleidingen is er sprake van een zekere geografische concentratie van de opleidingen, en is de banenmarkt veeleer landelijk dan regionaal. Het is daardoor moeilijk om de schoolverlaters uit deze opleidingen 'toe te kennen' aan een bepaalde regio. De mooiste oplossing zou zijn om na te gaan hoe de regionale mobiliteit samenhangt met de persoonlijke kenmerken van de schoolverlaters en de vraag in de diverse regio's. Dit zou in principe kunnen op basis van de data uit het Schoolverlaters Informatiesysteem (SIS) van het ROA, maar helaas is de regionale dekking 
van deze data zo ongelijk dat dit tot uiterst onplausibele resultaten zou leiden. Er is daarom gekozen voor een minder fraaie, maar wel robuustere methode. Op basis van het schoolverlatersmodel voor de prognoses voor de middellange termijn is vast te stellen hoe groot het aantal schoolverlaters landelijk zal zijn (Dit zijn de resultaten zoals die in hoofdstuk 3 getoond worden). Op basis van de EBB-data is per opleidingstype vast te stellen hoe de regionale verdeling is van diegenen die op dit moment een opleiding volgen. Op basis van twee aanvullende aannamen wordt nu het regionale aanbod van schoolverlaters vastgesteld. Er wordt eerst verondersteld dat de regionale verdeling van de schoolverlaters gelijk is aan deze regionale verdeling van scholieren. Vervolgens wordt verondersteld dat de regionale verdeling van de instroom op de arbeidsmarkt gelijk is aan de regionale verdeling van de schoolverlaters. Met andere woorden: er wordt eerst verondersteld dat er meer schoolverlaters voor een richting zijn in een regio waar relatief veel mensen deze opleiding volgen. Vervolgens wordt verondersteld dat men zich aanbiedt in de regio waarin men de opleiding gevolgd heeft. Dit hoeft bij de opleidingen waarvan het leerlingaantal relatief stabiel is, en waarbij sprake is van een gelijkmatige landelijke dekking niet tot grote voorspelfouten te leiden. Bij de hogere opleidingen met sterk wisselende aantallen studenten en een minder gelijkmatige regionale spreiding daarentegen kan deze methodiek tot relatief grote voorspelfouten leiden. De regionale cijfers voor de hogere opleidingen en de beroepssectoren waarin mensen met deze opleidingen werkzaam zijn kennen dus een lagere betrouwbaarheid.

\section{Typeringen}

Omdat de gebruikers van de regionale data (o.a. Arbeidsvoorziening) meer geïnteresseerd lijken in een vergelijking van verschillende opleidingen en beroepen binnen een regio, dan in een vergelijking tussen de regio's voor dezelfde opleidingen, is er voor gekozen om de typeringsgrenzen regionaal te bepalen. Dat wil zeggen dat per regio de typeringsgrenzen worden bepaald op basis van de in paragraaf 2.3 genoemde kwantielenmethode. Hierdoor zullen de voor de verschillende regio's gehanteerde typeringsgrenzen verschillen. De gegeven typeringen lenen zich derhalve voor het vergelijken van de relatieve situatie van de verschillende opleidings- en beroepssectoren binnen een regio. De typeringen lenen zich dus niet voor het vergelijken van de situatie van een bepaalde opleidings- of beroepssector in de verschillende regio's. Is bijvoorbeeld de vraag in een bepaalde regio voor alle opleidingen hoger dan het landelijk gemiddelde, dan nog zal $10 \%$ hiervan als 'zeer laag' getypeerd worden, omdat de typering uitsluitend op de regionale percentages gebaseerd is. Het is dus in principe mogelijk dat voor een bepaalde opleidings- of beroepssector in de ene regio een als 'hoog' getypeerd percentage lager is dan een in een andere regio als 'laag' getypeerd percentage. Met andere woorden, voor zo'n vergelijking tussen de regio's kunnen niet de typeringen worden gebruikt, maar moeten de onderliggende percentages gebruikt worden ${ }^{2}$. Een uitzondering hierop

2. Overigens houdt dit ook in dat het voor een zinvolle interpretatie van de cijfers binnen een regio geen kwaad kan ze te relateren aan de landelijke cijfers. Zo wordt bijvoorbeeld voor het aanbod in iedere regio altijd $10 \%$ als 'zeer laag' getypeerd. Het zonder meer 
wordt gevormd door de knelpuntindicator die in de volgende paragraaf gepresenteerd zal worden: omdat deze getypeerd wordt op basis van 'vaste grenzen' zijn deze typeringen wel vergelijkbaar tussen de regio's. Omdat in hoofdstuk 5 van dit rapport vooral vergelijkingen tussen regio's gemaakt zullen worden, worden in dat hoofdstuk uitsluitend percentages gebruikt en geen typeringen.

\subsection{De bepaling van knelpunten op de arbeidsmarkt}

Door de verwachte vraag- en aanbodstromen met elkaar te confronteren wordt een indicatie verkregen van de ontwikkelingen van het aantal werkenden per opleiding of beroep. Door deze verwachte ontwikkelingen te vergelijken met de gewenste ontwikkeling, zoals die weergegeven wordt door de uitbreidingsvraag, kan een indicatie verkregen worden van de knelpunten die op de arbeidsmarkt zullen optreden.

Deze knelpunten worden weergegeven door middel van een indicator die de spanning op de arbeidsmarkt weergeeft (ISA: Indicator Spanning op de Arbeidsmarkt). Deze indicator geeft aan in hoeverre er sprake is van een discrepantie tussen de totale vraag en het totale aanbod op de arbeidsmarkt. In principe kan er voor gekozen worden om het verschil tussen aanbod en vraag te beschouwen: als de vraag groter is dan het aanbod, dan is er sprake van een krappe arbeidsmarkt, als hij kleiner is, dan is er sprake van een ruime arbeidsmarkt. Echter, door alleen nominale vraag en aanbod van elkaar af te trekken, geeft een vergelijking van de indicatoren tussen verschillende groepen een vertekend beeld: de vraag of een nominaal tekort groot of klein is, is niet zo relevant als niet tegelijkertijd de totale omvang van de groep waar deze discrepantie betrekking op heeft daarbij betrokken wordt. Een tekort van 1.000 werknemers is in een relatief kleine beroepsgroep immers een groter probleem dan in een grote beroepsgroep. Vandaar dat het relatieve verschil tussen vraag en aanbod als basis van de indicator gebruikt wordt: de discrepantie gerelateerd aan de omvang van de groep waarop hij betrekking heeft. Deze keuze leidt in tegenstelling tot de indicatoren voor de middellange termijn - tot een 'symmetrische' indicator die aangeeft in hoeverre vraag en aanbod voor een bepaalde groep (beroep of opleiding) in evenwicht zijn. Merk op dat de discrepantie niet wordt gerelateerd aan het totale aanbod of de totale vraag. Hierdoor is de indicator ongevoelig voor de verhouding tussen discrepantie enerzijds en vraag of aanbod anderzijds. Als de discrepantie gerelateerd zou worden aan vraag of aanbod zou dit leiden tot een tweetal indicatoren, een vanuit een vraag- en een vanuit een aanbodperspectief. De keus die nu gemaakt is, geeft de situatie weer vanuit het 'arbeidsmarktperspectief ${ }^{3}$.

veronderstellen van een probleem bij deze sector kan tot misverstanden leiden als het aanbod vergeleken met het landelijk gemiddelde 'normaal' is.

3. De huidige keuze geeft aan in hoeverre er een marktevenwicht is voor een gegeven opleiding of beroep. Het relateren van de discrepantie aan de totale vraag of het totale aanbod zou leiden tot een indicator die gerelateerd is aan de kans dat een vacature niet vervuld of een werkzoekende werkloos zou blijven. 
Dit verschil met de indicatoren voor de middellange termijn heeft ook consequenties voor de interpretatie. De indicatoren voor de middellange termijn zijn geconstrueerd voor bepaalde groepen: de perspectieven voor nieuwkomers enerzijds en de knelpunten voor werkgevers anderzijds. Dit houdt in dat iedere groep zijn 'eigen' indicator heeft. De indicatoren zijn weliswaar met elkaar verwant, maar toch hoeft het niet zo te zijn dat een goed perspectief voor de schoolverlater samenvalt met een groot knelpunt voor de werkgever. Er zijn immers andere groepen aanbieders op de arbeidsmarkt aanwezig. De huidige indicator is niet geconstrueerd met het oog op een bepaalde groep, maar met het oog op de situatie op de arbeidsmarkt. De indicator geeft aan wat de situatie is op de arbeidsmarkt, en deze situatie heeft implicaties voor vragers en aanbieders van arbeid: als er sprake is van een ruime arbeidsmarkt, betekent dit minder goede perspectieven voor werkzoekenden, maar ook minder knelpunten voor werkgevers. Een krappe arbeidsmarkt daarentegen leidt tot betere perspectieven voor werkzoekenden en een grotere kans op knelpunten voor de werkgevers.

Er wordt bij het bepalen van de indicator geen onderscheid gemaakt tussen de diverse groepen op de arbeidsmarkt. Het is dus niet mogelijk om op basis van de nu gepresenteerde indicator uitspraken te doen over de vraag of de perspectieven van de drie groepen arbeidsaanbieders hetzelfde zijn, of juist sterk verschillen. Voor de ITA (Indicator Toekomstig Arbeidsmarktperspectief), zoals die in De arbeidsmarkt naar opleiding en beroep bepaald wordt, is de aanname gemaakt dat de perspectieven van schoolverlaters niet aangetast worden door werkgelegenheidskrimp. De impliciete aanname hierachter is dat de perspectieven van de overige aanbieders juist zeer sterk door deze krimp bepaald worden. Als deze aanname juist is, dan zou dat impliceren dat de positie van schoolverlaters iets beter is dan de gemiddelde positie van werkzoekenden zoals die op basis van de huidige spanningsindicator bepaald is, terwijl de positie van de herintreders dus iets slechter is dan deze indicator doet vermoeden.

Op de relatieve discrepantie wordt nog een wiskundige transformatie toegepast zodanig dat de indicator een waarde van 1 heeft bij een evenwicht op de arbeidsmarkt, groter is dan 1 bij een ruime arbeidsmarkt en kleiner is dan 1 bij een krappe arbeidsmarkt. De indicator ziet er in formulevorm als volgt uit:

$$
I S A=\exp \left(\frac{A-V}{W}\right)
$$

Hierin is $A$ het totale aanbod, $V$ de totale vraag, en $W$ het aantal werkenden. De $\exp ($.$) is de exponentiële functie die er voor zorgt dat de ISA de waarde 1$ heeft bij een marktevenwicht. Deze indicator kan bepaald worden voor iedere opleiding of beroep waarvoor betrouwbare prognoses voor vraag en aanbod gemaakt kunnen worden. Hierdoor kan zowel voor de landelijke als de regionale prognoses, en voor de prognoses op zowel hoog als laag aggregatieniveau, dezelfde formule gehanteerd worden. De exponent in de formule wordt gebruikt om technische redenen: hierdoor is de indicator altijd positief. Als vraag en aanbod ongeveer gelijk zijn, is de formule te benaderen met ISA $=1+(A-V) / W$. Het is dan ook direct in te zien dat als de 
vraag groter is dan het aanbod, de waarde van de ISA kleiner is dan 1, terwijl bij een aanbod dat groter is dan de vraag, de waarde groter is dan 1.

Samengevat heeft de ISA (Indicator Spanning op de Arbeidsmarkt) de volgende eigenschappen:

1. altijd positief;

2. bij een evenwicht op de arbeidsmarkt is de waarde 1 ;

3. bij een tekort aan arbeidskrachten is de waarde kleiner dan 1 ;

4. bij een overschot aan arbeidskrachten is de waarde groter dan 1;

5. een grote nominale discrepantie op een klein aantal werkenden is 'erger' dan dezelfde nominale discrepantie op een groot aantal werkenden, en dus wijkt bij een gegeven discrepantie de ISA verder af van 1 als het aantal werkenden kleiner is;

6. de ISA is uitsluitend afhankelijk van het verschil tussen vraag en aanbod, en niet van het niveau van vraag en aanbod.

\section{Typering van de indicator}

Of een discrepantie tussen vraag en aanbod van arbeidskrachten op de arbeidsmarkt positief dan wel negatief is, hangt af van de positie die men op die markt inneemt. Een tekort aan arbeidskrachten is gunstig vanuit het perspectief van de werkzoekende, maar ongunstig vanuit het perspectief van de werkgever. De typering van de indicator zal dus zo zijn dat uit de typering vanuit het ene perspectief de typering vanuit het andere direct volgt. Als het aanbod veel groter is dan de vraag (ISA veel groter dan 1) is er sprake van een slecht perspectief voor de werkzoekende, maar zullen er vanwege het aanbodoverschot geen knelpunten in de personeelsvoorziening zijn. Als het aanbod iets groter is dan de vraag (ISA iets groter dan 1) geldt er dat er vrijwel geen knelpunten in de personeelsvoorziening zullen zijn, maar wel dat er sprake is van een matig perspectief voor de werkzoekende met de desbetreffende opleiding of beroep. Als vraag en aanbod ongeveer gelijk zijn (ISA ongeveer 1) is er een evenwicht op de arbeidsmarkt, en is er alleen maar sprake is van zoekfrictie. Hierdoor heeft de werkzoekende een redelijk perspectief en zijn er enige knelpunten in de personeelsvoorziening voor de werkgever. Zodra de vraag iets groter wordt dan het aanbod is er sprake van een matig vraagoverschot (ISA iets kleiner dan 1) wat betekent dat er een goed perspectief voor de werkzoekende is, maar ook dat er grote knelpunten in de personeelsvoorziening voor de werkgever zijn. Als de vraag veel groter is dan het aanbod is er zelfs sprake van een zeer goed perspectief voor de werkzoekende en zeer grote knelpunten in de personeelsvoorziening. In lijn met deze redenering zijn de volgende grenzen gekozen voor de indicator: $0,97,0,985,1,015,1,03$. Dit correspondeert achtereenvolgens met een relatief vraagoverschot van $3 \%$, een vraagoverschot van $1,5 \%$, een aanbodoverschot van $1,5 \%$ en een aanbodoverschot van $3 \%$ (relatief t.o.v. het aantal werkenden met de desbetreffende opleiding/beroep). 


\subsection{Samenvatting}

In dit hoofdstuk is kort ingegaan op de methodiek die gehanteerd is om de arbeidsmarktprognoses voor de korte termijn te maken. $\mathrm{Er}$ is voor deze prognoses uitgegaan van een stroomcijferaanpak. In tegenstelling tot de methodiek voor de middellange termijn wordt hierbij niet uitgegaan van een netto maar van een brutostromenbenadering. Met bruto stromen wordt hier bedoeld de optelsom van alle individuele veranderingen op de arbeidsmarkt. Deze benadering heeft als voordeel dat zowel inzicht verkregen wordt in de bewegingen die plaatsvinden op de arbeidsmarkt, alsook in de mate waarin deze bewegingen afhangen van bv. Opleidingsniveau en -richting van de betrokkenen.

De prognoses richten zich in eerste aanleg op de ontwikkelingen binnen de groep werkenden. Vanuit deze groep vindt uitstroom plaats naar de groep scholieren en de groep niet-participerenden, er vindt baanmobiliteit plaats binnen de groep werkenden, of men verdwijnt - bv. door pensioen - buiten de potentiële beroepsbevolking. Aan de andere kant vindt er in deze groep instroom plaats, uit de groep scholieren (aangeduid als schoolverlaters), uit de groep niet-participerenden (aangeduid als herintreders), maar ook door baanmobiliteit (aangeduid als baanwisselaars). In deze bruto-stromenbenadering is het dus mogelijk om de totale uitstroom op te splitsen in vier groepen, en om de totale instroom op te splitsen in drie groepen. Om zoveel mogelijk aan te sluiten bij de prognoses voor de middellange termijn zal er zo veel mogelijk van dezelfde terminologie gebruik worden gemaakt. Hierbij moet wel bedacht worden dat zowel de vervangingsvraag als de instroom veel breder gedefinieerd zijn dan bij de prognoses voor de middellange termijn.

De prognoses voor de uitbreidingsvraag zijn gebaseerd op de werkgelegenheidsprognoses voor bedrijfssectoren van het Centraal Planbureau. Vanwege de nadruk op de korte termijn wordt hierbij uitgegaan van de arbeidsmarktprognoses voor de korte termijn afkomstig uit het Centraal Economisch Plan 2000. De prognoses voor de vervangingsvraag en de instroom van baanwisselaars en herintreders zijn gebaseerd op het stromenmodel dat geschat is op basis van het Sociaal-Economisch Panel, in combinatie met gegevens over de (potentiële) beroepsbevolking uit de EBB. De prognoses voor het aantal schoolverlaters zijn gebaseerd op het schoolverlatersmodel dat ontwikkeld is voor de prognoses voor de middellange termijn. De prognoses worden in principe opgesteld voor een relatief hoog aggregatieniveau van 11 beroepssectoren en 17 opleidingssectoren, gespreid over de volle breedte van de arbeidsmarkt. Daar waar mogelijk worden de prognoses ook gegeven voor in totaal 121 beroepsgroepen en 97 opleidingstypen. De resultaten daarvan worden echter niet in dit rapport vermeld, maar uitsluitend in de bijbehorende Statistische Bijlage. Naast een getalsmatige indicatie wordt ook een kwalitatieve typering gegeven van de prognose. Het doel van deze kwalitatieve typering is tweeledig. Allereerst vereenvoudigt de typering de interpretatie van de cijfers. Anderzijds wordt door deze kwalitatieve typering rekening gehouden met de onzekerheidsmarges waarmee het opstellen van prognoses gepaard gaat. 
Vanwege de toenemende behoefte aan regionale arbeidsmarktprognoses, worden niet uitsluitend landelijke prognoses gepresenteerd, maar ook een regionale verbijzondering daarvan. Er wordt daarbij een indeling in zes regio's gehanteerd, die gebaseerd is op de RBA-indeling. De methodiek die voor de regionale prognoses wordt gebruikt volgt in zeer grote lijnen de methodiek die voor de landelijke prognoses gebruikt wordt.

Door de verwachte vraag- en aanbodstromen met elkaar te confronteren wordt een indicatie verkregen van de ontwikkelingen in het aantal werkenden per opleiding of beroep. Door deze verwachte ontwikkelingen te vergelijken met de gewenste ontwikkeling, zoals die weergegeven wordt door de uitbreidingsvraag, kan een indicatie verkregen worden van de knelpunten op de arbeidsmarkt die op zullen gaan treden. Deze knelpunten worden weergegeven door middel van een indicator die de spanning op de arbeidsmarkt weergeeft (ISA: Indicator Spanning op de Arbeidsmarkf). Deze indicator geeft aan in hoeverre er sprake is van een discrepantie tussen de totale vraag en het totale aanbod op de arbeidsmarkt. Als er sprake is van een ruime arbeidsmarkt betekent dit minder goede perspectieven voor werkzoekenden, maar ook minder knelpunten voor werkgevers. Een krappe arbeidsmarkt daarentegen leidt tot betere perspectieven voor werkzoekenden en een grotere kans op knelpunten voor de werkgevers. 


\section{Stromen op de arbeidsmarkt}

\subsection{Inleiding}

In hoofdstuk 1 is een korte inleiding gegeven over het doel van de arbeidsmarktprognoses voor de korte termijn. De daar omschreven informatie kan het best gepresenteerd worden uitgaande van een model dat gebaseerd is op individuele overgangen op de arbeidsmarkt. In het vorige hoofdstuk is een korte inleiding op het model gegeven. In dit hoofdstuk zal een empirische illustratie van de diverse stromen gegeven worden. Paragraaf 3.2 toont de uitstroom, paragraaf 3.3 de baanmobiliteit, en in paragraaf 3.4 wordt de instroom geillustreerd. Paragraaf 3.5 tracht inzicht te geven in de concurrentiepositie van de diverse aanbieders op de arbeidsmarkt. In paragraaf 3.6 zullen ten slotte de belangrijkste bevindingen samengevat worden. In al deze paragrafen zal getracht worden de samenhang van deze stromen aan te geven met persoonlijke en baankenmerken. Verder zal in dit hoofdstuk ook al aansluiting worden gezocht bij het niveau waarop in hoofdstuk 4 de prognoses gepresenteerd zullen worden.

\subsection{Uitstroom van de arbeidsmarkt}

Uit eerder onderzoek naar het arbeidsaanbodgedrag (binnen het ROA verricht door Borghans e.a., 1998a, en De Grip en Vlasblom, 1999) is gebleken dat uitstroom gerelateerd kan worden aan een aantal kenmerken. Allereerst kan men dan denken aan persoonlijke kenmerken van de werkende zoals bv. geslacht, leeftijd en ervaring. Hoe ouder men is, des te hoger zijn de uitstroomkansen. Dit hangt enerzijds samen met de mogelijkheden die men heeft om met pensioen te gaan, maar anderzijds ook met de kans op baanverlies door bv. arbeidsongeschiktheid (Diephuis e.a., te verschijnen). Ook de kans op baanverlies door een tekort aan kennis en vaardigheden neemt toe naarmate men ouder wordt. Op deze processen wordt uitgebreid ingegaan in het rapport Werkgelegenheid en scholing 1999 (ROA, 2000).

Om aan te geven welke omvang deze samenhangen aannemen, worden er in deze paragraaf enkele voorbeelden van gegeven. Alle cijfers die gepresenteerd worden, zijn gebaseerd op het Sociaal-Economisch Panel van het CBS. Een vergelijking van de arbeidsmarktpositie op twee achtereenvolgende peildata in het databestand geeft aan of er een verandering heeft plaatsgehad, en zo ja, welke verandering dat geweest is ${ }^{4}$. Hierbij moet dan wel bedacht worden dat het dus gaat om de vergelijking van de situatie van de respondenten op twee achtereenvolgende enquêtemomenten. Deze momenten liggen een jaar uit elkaar. Alle veranderingen die daar tussen hebben plaatsgehad worden dus niet meegeteld. Dit kan een onderschatting opleveren van de werkelijke mobiliteit die plaatsvindt op de arbeidsmarkt.

In tabel 3.1 is aangegeven in hoeverre de individuele uitstroomkans (dat is de kans dat men zijn huidige baan verlaat) samenhangt met de leeftijd. De kans op

4. De enquêtes worden afgenomen in de maand april. 
verandering is met name heel hoog in de jongste leeftijdscategorie. Dit hangt samen met het feit dat in deze leeftijd een baan relatief vaak samenvalt met scholing of daar zelfs deel van uitmaakt. Daarnaast kan ook zoekmobiliteit een rol spelen bij de hoge uitstroomkans voor jongeren: het duurt tenslotte even voordat beginnende werkenden de baan gevonden hebben die het beste bij hen past. Daarna loopt de kans op verandering terug, ongeveer tot het $50^{\circ}$ jaar, waarna er weer een toename in de uitstroomkans te zien is. Deze toename is waarschijnlijk vrijwel geheel toe te schijven aan VUT en pensioen.

Het is te zien dat er een vrij groot verschil in uitstroomkans bestaat tussen mannen en vrouwen: $8 \%$ van de mannelijke werkenden maakt een verandering door, tegen $15 \%$ van de vrouwen. Zowel bij mannen als bij vrouwen is hetzelfde leeftijdspatroon zichtbaar, alhoewel voor vrouwen de uitstroomkans relatief hoog blijft tussen de 25 en de 50. Dit hangt samen met het zogenaamde 'kinderdal': vrouwen onderbreken hun loopbaan om zich te wijden aan het krijgen en opvoeden van kinderen. In alle leeftijdscategorieën kennen vrouwen een hogere uitstroomkans dan mannen. Aan het begin van de loopbaan is dit verschil relatief klein (slechts 2 procentpunt), maar in de leeftijdscategorie $35-40$ is het verschil gegroeid tot 11 procentpunt. Pas in de oudste categorie neemt het verschil weer af ${ }^{5}$.

Tabel 3.1

Kans op verandering van arbeidsmarktpositie, naar leeftijd en geslacht ${ }^{a)}$

\begin{tabular}{lccc}
\hline Leeftijd & $\begin{array}{c}\text { Mannen } \\
\%\end{array}$ & $\begin{array}{c}\text { Geslacht } \\
\text { Vrouwen } \\
\%\end{array}$ & $\begin{array}{c}\text { Totaal } \\
\%\end{array}$ \\
\hline $15-20$ & 32 & 34 & 33 \\
$20-25$ & 16 & 18 & 17 \\
$25-30$ & 8 & 12 & 10 \\
$30-35$ & 6 & 14 & 9 \\
$35-40$ & 5 & 16 & 9 \\
$40-45$ & 4 & 9 & 6 \\
$45-50$ & 3 & 13 & 7 \\
$50-55$ & 7 & 23 & 23 \\
$55-60$ & 23 & 20 & 32 \\
$60-65$ & 38 & 15 & 11 \\
Totaal & 8 & & \\
\hline
\end{tabular}

a) Het betreft hier veranderingen tussen twee een jaar uit elkaar liggende meetmomenten Bron: SEP '94-'96/ROA

Zoals in de beschrijving van het arbeidsmarktmodel in paragraaf 2.2 is aangegeven, is er uitstroom mogelijk naar een aantal 'bestemmingen'. Ook deze 'bestemmings-

5. Voor het cohort $60-65$ is de kans bij vrouwen zelfs lager, maar vanwege de relatief kleine aantallen waarop dit cijfer gebaseerd is, is dit verschil niet significant. 
categorie' kan gerelateerd worden aan persoonlijke kenmerken zoals leeftijd, geslacht en opleiding. In tabel 3.2 wordt de uitstroombestemming gerelateerd aan leeftijd en geslacht. Er wordt daarbij onderscheid gemaakt tussen uitstroom naar een volgende baan, naar werkloosheid, naar non-participatie en naar studie. ${ }^{6}$. Van de totale uitstroom gaat bijna de helft naar een andere baan, wordt iets meer dan $10 \%$ werkloos, $34 \%$ verlaat de arbeidsmarkt, terwijl ca. $10 \%$ aan een opleiding begint. Afgezien van de jongste leeftijdscategorie, is er een duidelijk patroon zichtbaar: hoe ouder men wordt, des te kleiner de kans dat men naar een andere baan vertrekt, of werkloos wordt. Boven de 55 lijkt vrijwel iedereen die van arbeidsmarktpositie verandert, de arbeidsmarkt geheel te verlaten (al dan niet gedwongen door de omstandigheden). De jongste leeftijdscategorie laat een iets ander beeld zien, daar blijkt vrijwel de helft aan een opleiding te beginnen. Hier is waarschijnlijk sprake van een zekere overschatting, vanwege het feit dat in de EBB en SEP-data van het Centraal Bureau voor de Statistiek de belangrijkste bezigheid in de week van ondervragen als basis voor de bepaling van de arbeidsmarktpositie gebruikt wordt. Er blijkt een vrij grote mobiliteit te zijn tussen school en arbeidsmarkt. Omdat veel opleidingen tegenwoordig een werkcomponent hebben, en omdat daarnaast veel scholieren en studenten een bijbaantje hebben, wisselen zij 'te vaak' van arbeidsmarktpositie. Uit de tabel blijkt dat er ook een verschil bestaat tussen de uitstroombestemming van mannen en vrouwen. Mannen gaan veel vaker naar een andere baan, terwijl vrouwen daarentegen - als zij van positie veranderen - veel vaker de arbeidsmarkt definitief verlaten of zich in ieder geval voor langere tijd terugtrekken van de arbeidsmarkt. Het percentage mannen en vrouwen dat werkloos of scholier wordt als ze van arbeidsmarktpositie veranderen is ongeveer gelijk. Omdat het percentage van de werkende vrouwen dat van positie verandert groter is dan dat van de mannen is er dus een groot verschil in de percentages werkenden dat de arbeidsmarkt verlaat ( $15 \%$ * $40 \%$ voor de vrouwen tegen $8 \%$ * $26 \%$ voor de mannen).

Zoals gezegd kunnen de mobiliteitscijfers vertekend zijn vanwege het feit dat ze gebaseerd zijn op een vergelijking van de situatie op twee momenten. Zo geven de cijfers bijvoorbeeld aan dat van die mensen die op het eerste moment werkzaam waren maar op het tweede moment niet, $11 \%$ op het tweede moment werkloos was. Gedurende dat jaar zullen waarschijnlijk veel meer mensen met kortdurende werkloosheid geconfronteerd zijn, maar die worden in deze tabellen niet meegeteld. Het is dus zeker onjuist om de tabel zo te lezen dat slechts $11 \%$ (de kans op verandering) ${ }^{*} 11 \%$ (de kans op werkloosheid gegeven verandering) $=1,5 \%$ van de werkenden werkloos zou worden. Dit zou een aantal van nog geen 100.000 mensen per jaar zijn. Het feitelijke aantal ligt veel hoger, waarbij het verschil veroorzaakt wordt door die mensen die korter dan een jaar werkloos zijn.

Behalve een verschil naar leeftijd en geslacht is er ook een verschil in uitstroomkans naar opleidingsniveau, zoals getoond wordt in tabel 3.3. De mobiliteit is het laagste op de laagste opleidingsniveaus. De hogere opleidingsniveaus kennen een hogere

6. Uitstroom naar een volgende baan wordt in dit rapport aangeduid met 'baanmobiliteit', in Borghans e.a.(1998a) wordt het ook wel aangeduid met de term 'doorstroom'. 
uitstroom, waarbij die op het WO-niveau iets lager is dan die op het HBO-niveau. Dit patroon wekt in eerste instantie enige verbazing, omdat doorgaans wordt gedacht dat juist de laagst opgeleiden de minste baanzekerheid hebben, en daardoor de hoogste uitstroomkans. Maar er moet bedacht worden dat in deze tabellen geen onderscheid gemaakt kan worden tussen vrijwillige en gedwongen mobiliteit. Het kan dus zo zijn dat een hoge vrijwillige mobiliteit van de hoger opgeleiden de oorzaak is van dit patroon, en dat de gedwongen mobiliteit (die bepalend is voor de baanzekerheid) veel hoger is voor de lager opgeleiden.

Tabel 3.2

Bestemming van de uitstroom naar leeftijd en geslacht

\begin{tabular}{|c|c|c|c|c|}
\hline \multirow[b]{2}{*}{ Leeftijd } & \multirow[b]{2}{*}{$\begin{array}{c}\text { andere baan } \\
\%\end{array}$} & \multicolumn{2}{|c|}{ Bestemming } & \multirow[b]{2}{*}{$\begin{array}{c}\text { studie } \\
\%\end{array}$} \\
\hline & & $\begin{array}{c}\text { werkloos } \\
\%\end{array}$ & $\begin{array}{c}\text { non-participatie } \\
\%\end{array}$ & \\
\hline $15-20$ & 37 & 4 & 10 & 49 \\
\hline $20-25$ & 53 & 11 & 20 & 16 \\
\hline $25-30$ & 58 & 14 & 26 & 2 \\
\hline $30-35$ & 51 & 16 & 31 & 3 \\
\hline $35-40$ & 51 & 15 & 31 & 3 \\
\hline $40-45$ & 51 & 8 & 42 & - \\
\hline $45-50$ & 47 & 13 & 38 & 3 \\
\hline $50-55$ & 26 & 13 & 57 & 3 \\
\hline $55-60$ & 4 & 1 & 91 & 3 \\
\hline $60-65$ & 15 & - & 85 & - \\
\hline Mannen & 52 & 12 & 26 & 10 \\
\hline Vrouwen & 40 & 10 & 40 & 9 \\
\hline Totaal & 45 & 11 & 34 & 10 \\
\hline
\end{tabular}

Bron: SEP '94-'96/ROA

Tabel 3.3

Uitstroomkans naar opleidingsniveau en leeftijd

\begin{tabular}{lcccr}
\hline Opleidingsniveau & $\begin{array}{c}\text { Leeftijd } \\
\%\end{array}$ & $\begin{array}{c}35-49 \\
\%\end{array}$ & $\begin{array}{c}50-64 \\
\%\end{array}$ & $\begin{array}{r}\text { Totaal } \\
\%\end{array}$ \\
\hline Basisonderwijs & 12 & 7 & 14 & 10 \\
VMBO & 15 & 13 & 19 & 14 \\
MBO & 17 & 7 & 6 & 14 \\
HBO & 24 & 8 & 17 & 19 \\
WO & 14 & 20 & - & 15 \\
Totaal & 14 & 8 & 14 & 11 \\
\hline
\end{tabular}

Bron: SEP '94-'96/ROA

Ook in deze tabel is weer het verband tussen uitstroomkans en leeftijd te zien: op alle opleidingsniveaus is de uitstroom van de jongeren en ouderen hoger dan van de 
mensen van middelbare leeftijd. Alleen op het MBO-niveau lijkt de uitstroom van ouderen niet significant hoger te liggen dan van de werkerenden van middelbare leeftijd. Dit zou veroorzaakt kunnen worden door het feit dat er op het MBO-niveau in vrij veel sectoren sprake is van een tekort, terwijl op de lagere niveaus sprake is van overschotten. Het niet - gedwongen - laten uitstromen van oudere werknemers is een manier om tekorten aan personeel te verminderen of op te lossen. Ook hierbij is het dus noodzakelijk om onderscheid te kunnen maken tussen gedwongen en vrijwillige mobiliteit.

In tabel 3.4 wordt aangegeven in hoeverre de uitstroombestemming afhangt van het opleidingsniveau. Het blijkt dat de baanmobiliteit aanzienlijk hoger is voor de hoger opgeleiden. Van de totale uitstroom op WO niveau gaat $62 \%$ naar een andere baan, terwijl dit voor de laag opgeleiden nog geen $40 \%$ is. Daarentegen is de uitstroom naar non-participatie veel hoger op de lagere opleidingsniveaus. Van de totale uitstroom van ongeschoolden verlaat $40 \%$ de arbeidsmarkt. De uitstroom naar werkloosheid is op alle niveaus ongeveer gelijk. Het valt op dat terugkeer naar een opleiding eigenlijk alleen voor mensen op het VMBO-niveau een optie is, alhoewel ook van de ongeschoolden en de MBO'ers nog bijna 10\% naar een opleiding terugkeert. Voor de hoger opgeleiden is het volgen van een opleiding nadat men al gewerkt heeft blijkbaar geen optie meer: van de WO'ers gaat slechts vier procent een opleiding volgen. Dit suggereert dat mensen op het VMBO-niveau die hun baan verliezen beseffen dat aanvullende scholing hun kansen op een baan vergroot omdat hun huidige niveau tekort schiet. Voor de ongeschoolden zal het volgen van een aanvullende opleiding veel moeilijker zijn, terwijl voor de hoog opgeleiden een aanvullende opleiding nauwelijks rendement zal hebben in termen van baankansen, waardoor op deze niveaus het volgen van scholing veel minder voorkomt. Bij benadering kan het verschil in mobiliteit naar een andere baan versus mobiliteit naar werkloosheid gezien worden als een indicatie van de verschillen in vrijwillige versus gedwongen mobiliteit. Uitgaande hiervan blijkt dat inderdaad de vrijwillige mobiliteit van WO'ers veel hoger is dan die van laaggeschoolden.

Tabel 3.4

Bestemming van de uitstroom naar opleidingsniveau

\begin{tabular}{|c|c|c|c|c|}
\hline \multirow[b]{2}{*}{ Opleidingsniveau } & \multirow[b]{2}{*}{$\begin{array}{c}\text { andere baan } \\
\%\end{array}$} & \multicolumn{2}{|c|}{ Bestemming } & \multirow[b]{2}{*}{$\begin{array}{l}\text { studie } \\
\%\end{array}$} \\
\hline & & $\begin{array}{c}\text { werkloos } \\
\%\end{array}$ & $\begin{array}{c}\text { non-participatie } \\
\%\end{array}$ & \\
\hline Basisonderwijs & 39 & 13 & 40 & 9 \\
\hline VMBO & 37 & 10 & 35 & 18 \\
\hline MBO & 48 & 11 & 34 & 8 \\
\hline HBO & 51 & 14 & 30 & 6 \\
\hline Wo & 62 & 11 & 22 & 4 \\
\hline Totaal & 45 & 11 & 34 & 10 \\
\hline
\end{tabular}

Bron: SEP '94-'96/ROA

Behalve persoonlijke kenmerken spelen ook kenmerken van de functie een rol. Zo blijkt de fysieke belasting van de functie een rol te spelen in de kans dat men van 
arbeidsmarktpositie verandert: de kans op uitstroom wordt groter naarmate het werk een hogere belasting geeft (Diephuis e.a., te verschijnen). Ten slotte kan ook de arbeidsmarktsituatie een rol spelen bij het verlies van de baan: een grote krapte op de arbeidsmarkt voor bepaalde beroepen of opleidingen lijkt de mobiliteit voor die beroepen en opleidingen te vergroten (pull-factoren), terwijl een krimpende werkgelegenheid in het eigen beroep de mobiliteit ook lijkt te vergroten (push-factoren) (zie: Willems e.a., 1997).

Tabel 3.5

Uitstroom naar bestemming per beroepssector

\begin{tabular}{|c|c|c|c|c|c|}
\hline \multirow[t]{2}{*}{ Beroepssector } & \multirow[b]{2}{*}{$\begin{array}{l}\text { Uitstroom- } \\
\text { kans } \\
\%\end{array}$} & \multicolumn{4}{|c|}{ Verdeling over de bestemmingen } \\
\hline & & $\begin{array}{c}\text { Andere } \\
\text { baan } \\
\%\end{array}$ & $\begin{array}{c}\text { Werkloos } \\
\%\end{array}$ & $\begin{array}{c}\text { Non- } \\
\text { participatie } \\
\%\end{array}$ & $\begin{array}{c}\text { Studie } \\
\%\end{array}$ \\
\hline Pedagogische beroepen & 7 & 37 & 5 & 47 & 11 \\
\hline Culturele beroepen & 14 & 67 & 6 & 11 & 17 \\
\hline Agrarische beroepen & 11 & 36 & 5 & 41 & 18 \\
\hline Technische en industrieberoepen & 10 & 45 & 14 & 34 & 7 \\
\hline Transportberoepen & 11 & 42 & 16 & 32 & 10 \\
\hline Medische en paramedische beroepen & 7 & 61 & 5 & 25 & 9 \\
\hline Economisch-administratieve beroepen & 10 & 48 & 13 & 33 & 5 \\
\hline Informaticaberoepen & 8 & 55 & 14 & 18 & 14 \\
\hline Sociaal-culturele beroepen & 10 & 55 & 14 & 28 & 3 \\
\hline Verzorgende en dienstverlenende & & & & & \\
\hline beroepen & 19 & 39 & 8 & 38 & 15 \\
\hline Openbare orde- en veiligheidsberoepen & 8 & 30 & 50 & 10 & 10 \\
\hline Totaal & 11 & 45 & 11 & 34 & 10 \\
\hline
\end{tabular}

Bron: SEP '94-'96/ROA

De invloed van de aan de functie en de sector gerelateerde factoren is terug te zien als de uitstroom per sector gegeven wordt. In tabel 3.5 wordt de uitstroomkans per sector gepresenteerd en ook de verdeling over de bestemmingen. De uitstroomkansen tussen de verschillende sectoren verschillen vrij sterk. De pedagogische beroepen en de medische en paramedische beroepen hebben met $7 \%$ de laagste uitstroomkans, terwijl de verzorgende en dienstverlenende beroepen met $19 \%$ een relatief hoge uitstroomkans hebben. Er blijken ook grote verschillen tussen de sectoren te bestaan in de uitstroombestemming. Bij de pedagogische beroepen, de agrarische beroepen en de openbare orde- en veiligheidsberoepen komt de laagste doorstroom voor: in deze sectoren verlaat het grootste deel van de uitstromers de arbeidsmarkt. Bij de culturele beroepen en de medische en paramedische beroepen is de doorstroom het grootst: ruim $60 \%$ van de uitstroom vertrekt naar een andere baan. Merk op dat de verschillen in tabel 3.5 niet gecorrigeerd zijn voor het opleidingsniveau en de leeftijd van de werkenden in de sector. Het patroon in tabel 3.5 kan dus ten dele veroorzaakt worden door het feit dat bv. de agrarische sector een vergrijzende beroepsbevolking kent, en dat in het onderwijs relatief veel vrouwen werkzaam zijn. 


\subsection{Baanmobiliteit op de arbeidsmarkt}

In de vorige paragraaf is de bruto uitstroom gerelateerd aan een aantal persoonsdan wel functie- of sectorgebonden kenmerken. In deze paragraaf komt de baanmobiliteit aan de orde. De bruto uitstroom gecorrigeerd voor de baanmobiliteit maakt de netto uitstroom: de netto uitstroom is de totale bruto uitstroom minus de groep werkenden die van baan verandert. Een van de eerste zaken die van belang is voor de baanmobiliteit, is de vraag in hoeverre er sprake is van baanmobiliteit binnen de beroepssector, of dat men gaat werken in een andere beroepssector. Baanmobiliteit binnen een beroepssector betekent dat men van baan verandert waarbij men in hetzelfde - of een nauw gerelateerd beroep - blijft werken. Baanmobiliteit buiten de sector betekent dat men niet alleen van baan verandert, maar daarnaast ook werkzaam wordt in een ander beroep dan waarin men werkzaam was. Ook deze keuze kan gerelateerd worden aan de kenmerken zoals die in paragraaf 3.2 genoemd zijn.

Tabel 3.6

Bestemming van de baanmobiliteit naar leeftijd en geslacht

\begin{tabular}{lcc}
\hline Leeftijd & $\begin{array}{c}\text { Naar dezelfde sector } \\
\%\end{array}$ & $\begin{array}{c}\text { Naar andere sector } \\
\%\end{array}$ \\
\hline $15-20$ & 49 & 51 \\
$20-25$ & 68 & 32 \\
$25-30$ & 71 & 29 \\
$30-35$ & 78 & 22 \\
$35-40$ & 80 & 20 \\
$40-45$ & 68 & 33 \\
$45-50$ & 78 & 22 \\
$50-55$ & 81 & 19 \\
$55-60$ & 67 & 33 \\
$60-65$ & - & 100 \\
Man & 64 & 36 \\
Vrouw & 79 & 21 \\
Totaal & 71 & 29 \\
\hline
\end{tabular}

Bron: SEP '94-'96/ROA

In tabel 3.6 wordt aangegeven in hoeverre de keus tussen een baan in een andere dan wel dezelfde sector leeftijdsgebonden is. Van alle mensen die van baan wisselen keert bijna driekwart terug binnen dezelfde sector. De cijfers in de tabel suggereren een niet-lineair verband met de leeftijd: jongeren veranderen relatief vaak van sector, terwijl dat op middelbare leeftijd veel minder gebeurt. De baanwisselaars tussen de 40 en de $\mathbf{4 5}$ daarentegen veranderen weer relatief vaker van sector. Hier lijkt weer sprake te zijn van zoekmobiliteit: jongeren zijn nog op zoek naar de 'ideale baan'. Bij de ouderen zou er sprake kunnen zijn van een overstap die gekoppeld is aan een 'carrièrestap': na een aantal jaren ervaring in een bepaalde sector kan men niet verder komen, en moet men overstappen naar een andere sector om door te kunnen groeien. Maar ook daar kan er sprake zijn van een overstap 'omdat men aan iets 
nieuws toe is'. In sectoren waar men relatief veel werknemers verliest aan andere sectoren is het van belang om hierover meer kennis te verkrijgen.

Naast een verschil in baanmobiliteit tussen verschillende cohorten blijkt er ook een verschil tussen mannen en vrouwen te zijn: vrouwen stappen veel minder over naar een andere sector dan mannen. Dat kan te maken hebben met het feit dat veel vrouwen een sectorspecifieke opleiding hebben (onderwijs, zorgsector), maar ook met het eerder genoemde argument van het carrièreperspectief. Nog steeds is het zo dat veel mannen kostwinner zijn en dat veranderingen van baan bij hen gekoppeld zijn aan een carrière. Veel veranderingen bij de vrouwen daarentegen worden veroorzaakt omdat het gezin verhuisd is vanwege een andere werkkring van de man. In dat geval zoekt de vrouw waarschijnlijk een vergelijkbare baan in dezelfde sector. Nader onderzoek naar de reden van baanmobiliteit zou hiervoor noodzakelijk zijn.

Ook voor de baanmobiliteit kan er onderzocht worden hoe deze samenhangt met het opleidingsniveau. Zoals in tabel 3.7 te zien is, is er sprake van een opvallend patroon. Zowel de ongeschoolden als de hoogopgeleiden veranderen relatief vaak van sector (meer dan $40 \%$ ), terwijl de niveaus daartussen in driekwart van de gevallen mobiel zijn binnen hun eigen beroepssector. De verklaring hiervoor moet gezocht worden in de mate van beroepsspecificiteit van de opleiding. Deze is bij het beroepsonderwijs doorgaans veel hoger dan bij de ongeschoolden en de WOopgeleiden. Dit maakt 'sectormobiliteit' voor deze beide niveaus relatief gemakkelijk. Net zoals dit bij de uitstroom het geval is, zal er ook hier waarschijnlijk een verschil zijn tussen de vrijwillige en gedwongen mobiliteit.

Tabel 3.7

Bestemming van de baanmobiliteit naar opleidingsniveau

\begin{tabular}{lcc}
\hline Opleidingsniveau & $\begin{array}{c}\text { Naar dezelfde sector } \\
\%\end{array}$ & $\begin{array}{c}\text { Naar andere sector } \\
\%\end{array}$ \\
\hline Basisonderwijs & 58 & 42 \\
VMBO & 75 & 25 \\
MBO & 75 & 25 \\
HBO & 75 & 25 \\
WO & 57 & 43 \\
Totaal & 71 & 29 \\
\hline
\end{tabular}

Bron: SEP '94-'96/ROA

De baanmobiliteit naar dezelfde of een andere sector lijkt ook beïnvloed te worden door de ervaring waarover men beschikt. In tabel 3.8 staat aangegeven dat hoe meer ervaring, des te kleiner de kans dat men doorstroomt naar een baan buiten de eigen beroepssector. Voor een deel komt dit omdat ervaring en leeftijd gekoppeld zijn. Uit een aanvullende - niet in de tabel weergegeven - analyse blijkt dat ook als baanmobiliteit gerelateerd wordt aan zowel leeftijd als ervaring, ervaring van belang lijkt voor de mobiliteit. Niet zo zeer voor het vóórkomen van mobiliteit, maar wel voor de vraag of men vertrekt naar een baan binnen of buiten de eigen beroepssector. 
Tabel 3.8

Bestemming van de baanmobiliteit naar ervaring in de huidige functie

\begin{tabular}{lcc}
\hline Ervaring & $\begin{array}{c}\text { Naar dezelfde sector } \\
\%\end{array}$ & $\begin{array}{c}\text { Naar andere sector } \\
\%\end{array}$ \\
\hline 0 jaar & 64 & 36 \\
$1-2$ jaar & 69 & 31 \\
3-5 jaar & 75 & 25 \\
-10 jaar & 74 & 26 \\
$10-15$ jaar & 80 & 20 \\
$15-20$ jaar & 80 & 20 \\
20 jaar en meer & 83 & 17 \\
Totaal & 71 & 29 \\
\hline
\end{tabular}

Bron: SEP '94-'96/ROA

Door de verschillen in beroepskenmerken en de arbeidsmarktsituatie in de verschillende beroepssectoren bestaan er mogelijk ook verschillen in de baanmobiliteit tussen de sectoren. In de volgende twee tabellen worden deze verschillen geïllustreerd. Ook nu wordt er niet gecorrigeerd voor verschillen in leeftijdsopbouw en opleidingsniveau tussen de sectoren. De baanmobiliteit kan op twee manieren bekeken worden: er kan voor de diverse beroepssectoren nagegaan worden of 'vertrekkers' verdwijnen naar een baan binnen dezelfde sector, of juist naar een andere sector. Daarnaast kan er per sector ook nagegaan worden of de 'binnenkomers' komen uit dezelfde of juist uit een andere sector. Merk hierbij op dat de totale hoeveelheid 'vertrekkers' per definitie gelijk is aan het aantal 'binnenkomers': baanmobiliteit is uitsluitend een proces van herverdeling van de werkenden.

In tabel 3.9 staat aangegeven in hoeverre de baanmobiliteit verschilt per beroepssector. Ongeveer driekwart van de mensen die mobiel zijn keert terug in de eigen sector, maar er zijn vrij grote verschillen tussen de sectoren. Van de mensen die werkzaam waren in de informaticaberoepen is vrijwel iedereen (92\%) mobiel binnen de sector. Ook voor de medische en paramedische beroepen, de economisch-administratieve beroepen en de verzorgende en dienstverlenende beroepen blijft bijna $80 \%$ van de 'vertrekkers' binnen de sector. Aan de andere kant blijkt van de 'vertrekkers' uit de culturele beroepen slechts de helft binnen de beroepssector te blijven. Hoewel deze tabel lijkt te suggereren dat de meeste sectoren er in slagen hun werknemers vast te houden, wil dit nog niet zeggen dat dit ook geldt voor de afzonderlijke beroepen binnen de sectoren.

Tabel 3.9 neemt de beroepen vanwaar men 'vertrekt' als uitgangspunt. In tabel 3.10 is te zien hoe het zit met de herkomst van 'binnenkomers' vanuit andere beroepen. Merk op dat in de eerste kolom van tabel 3.9 en tabel 3.10 verschillende percentages staan. Dit ondanks het feit dat de aantallen waar het over gaat dezelfde zijn. Het verschil in de percentages wordt veroorzaakt door het feit dat de totale in- en uitstroom niet even groot zijn. Dit geldt uiteraard niet voor de totaalregel: $71 \%$ van de instroom komt dus uit dezelfde sector, en $29 \%$ komt vanuit een andere sector. 
Tabel 3.9

Bestemming van de baanmobiliteit naar herkomst per beroepssector

\begin{tabular}{lcc}
\hline Sector van herkomst & $\begin{array}{c}\text { Nieuwe baan in } \\
\text { dezelfde sector } \\
\%\end{array}$ & $\begin{array}{c}\text { Nieuwe baan in } \\
\text { andere sector } \\
\%\end{array}$ \\
\hline Pedagogische beroepen & 57 & 43 \\
Culturele beroepen & 50 & 50 \\
Agrarische beroepen & 57 & 43 \\
Technische en industrieberoepen & 71 & 29 \\
Transportberoepen & 67 & 33 \\
Medische en paramedische beroepen & 78 & 22 \\
Economisch-administratieve beroepen & 78 & 22 \\
Informaticaberoepen & 92 & 8 \\
Sociaal-culturele beroepen & 56 & 44 \\
Verzorgende en dienstverlenende beroepen & 75 & 25 \\
Openbare orde- en veiligheidsberoepen & 67 & 33 \\
Totaal & 71 & 29 \\
\hline
\end{tabular}

Bron: SEP '94-'96/ROA

Ook in tabel 10 valt de sector medische en paramedische beroepen op: van de totale instroom van ervaren mensen komt $95 \%$ uit dezelfde sector. Blijkbaar is het heel moeilijk om met ervaring opgedaan in een andere beroepssector werk te vinden in deze sector. De pedagogische beroepen vallen juist op, omdat zij hun instroom voor maar liefst $47 \%$ buiten de eigen sector halen. Omdat het voor het geven van onderwijs meestal noodzakelijk is een zeer specifieke opleiding gevolgd te hebben, kan de conclusie niet zijn dat het makkelijk is om met ervaring opgedaan in andere beroepen het onderwijs in te gaan. De conclusie moet veeleer zijn dat diegenen die een opleiding gevolgd hebben waarmee ze in het onderwijs werkzaam kunnen zijn hun werk buiten die sector gezocht hebben. Blijkbaar is de opleiding algemeen genoeg om makkelijk buiten het onderwijs werkzaam te worden, iets dat ook blijkt uit tabel 3.9. Een oplossing voor de tekorten in het onderwijs zou dus gelegen kunnen zijn in het beter vasthouden van mensen met een passende opleiding. Een andere verklaring voor de hoge instroom uit andere sectoren zou kunnen zijn dat het in het verleden moeilijk was om in het onderwijs aan een baan te komen, zodat veel mensen met de juiste opleiding na het afronden van hun opleiding eerst in een ander beroep werkzaam waren, en nu de behoefte aan personeel toeneemt alsnog kiezen voor een baan in het onderwijs. In dat geval is het de vraag of dit percentage in de toekomst zo hoog zal blijven als in tabel 3.10 vermeld is.

Wat slechts heel moeilijk uit tabel 3.9 en 3.10 af te leiden is, is de vraag of een sector per saldo meer mensen opneemt uit andere sectoren of juist kwijtraakt aan andere sectoren. Met andere woorden: is de netto baanmobiliteit positief of negatief? 
Tabel 3.10

Herkomst baanmobiliteit naar bestemming per beroepssector

\begin{tabular}{lcc}
\hline Sector van bestemming & $\begin{array}{c}\text { Vorige baan in } \\
\text { dezelfde sector } \\
\%\end{array}$ & $\begin{array}{c}\text { Vorige baan in } \\
\text { andere sector } \\
\%\end{array}$ \\
\hline Pedagogische beroepen & 53 & 47 \\
Culturele beroepen & 86 & 14 \\
Agrarische beroepen & 53 & 47 \\
Technische en industrieberoepen & 66 & 34 \\
Transportberoepen & 56 & 44 \\
Medische en paramedische beroepen & 95 & 5 \\
Economisch-administratieve beroepen & 73 & 27 \\
Informaticaberoepen & 73 & 27 \\
Sociaal-culturele beroepen & 60 & 40 \\
Verzorgende en dienstverlenende beroepen & 82 & 18 \\
Openbare orde- en veiligheidsberoepen & 100 & - \\
& & 29 \\
Totaal & 71 & \\
\hline
\end{tabular}

Bron: SEP '94-'96/ROA

In tabel 3.11 wordt deze informatie getoond: in deze tabel staat aangegeven hoe de verdeling van de baanmobiliteit is, verdeeld naar de vraag of men binnen de sector blijft, het percentage dat de sector verlaat, en het percentage dat de sector binnenkomt. Merk op dat het in deze tabel uitsluitend om een herverdeling van een groep mensen gaat: de totale groep blijft even groot. Er blijken tussen de sectoren niet zoveel verschillen te zijn, en baanmobiliteit blijkt maar nauwelijks bij te dragen aan de herverdeling van de werkenden over de sectoren. De culturele beroepen en de verzorgende en dienstverlenende beroepen vallen op door een hoge interne mobiliteit, maar ook omdat in deze twee sectoren een vrij groot deel van de werkenden verdwijnt naar andere sectoren. De transportberoepen en de openbare orde- en veiligheidsberoepen daarentegen nemen relatief veel werkenden uit andere sectoren op. Dat wil overigens nog niet zeggen dat de sector transport als geheel groeit: alleen dat ze relatief veel ervaren mensen opneemt, en er niet zoveel kwijtraakt.

Een laatste aspect van de doorstroom dat met name voor het scholings- en bemiddelingsbeleid binnen een sector van belang kan zijn, is de vraag in hoeverre baanmobiliteit binnen de beroepssector ook gepaard gaat met een stijging van het functieniveau. Deze informatie is van belang bij de beantwoording van de vraag hoe tekorten bij de hogere beroepsniveaus opgelost kunnen worden. Als baanmobiliteit in veel gevallen gepaard gaat met zo'n stijging, dan kan dat er op duiden dat voor het vervullen van hogere beroepen in die sector ervaring binnen de sector gewenst dan wel noodzakelijk is. Als er dan tekorten op het niveau van deze hogere beroepen zijn, dan is het bijscholen van schoolverlaters of herintreders misschien niet altijd de beste manier. In dat geval moet men juist de doorgroei binnen de sector trachten te 
bevorderen teneinde de krapte bij de hogere functies te doen afnemen. Dit heeft dan tegelijk tot gevolg dat er een verschuiving optreedt in de 'kwaliteit' van de vacatures die vervuld worden door mensen die aangetrokken worden van buiten de sector (de zogenaamde externe vacatures). De eisen die men gaat stellen aan deze mensen zullen lager worden. Hierdoor krijgen de werkgevers in geval van personeelsschaarste meer mogelijkheden om uit te wijken naar mensen met een lagere of minder goed aansluitende opleiding. Een dergelijk doorgroeimodel waarbinnen de kwaliteit van externe vacatures verlaagd wordt, wordt een cascademodel genoemd (zie o.a. Hofman, 1991). Als baanmobiliteit doorgaans niet met een stijging van het functieniveau gepaard gaat, dan is ervaring binnen de sector blijkbaar niet nodig om binnen de sector naar een hoger functieniveau door te groeien. In dat geval kan ook scholing van andere werkzoekenden mogelijk een belangrijke bijdrage leveren aan het oplossen van de tekorten binnen de sector. Het voor dit rapport gebruikte databestand leverde helaas onvoldoende informatie om dit soort processen betrouwbaar mee te kunnen beschrijven. Nader onderzoek naar mobiliteit gekoppeld aan stijging van het functieniveau is dus noodzakelijk.

Tabel 3.11

Sectormobiliteit als percentage van het aantal werkenden per beroepssector

\begin{tabular}{lccc}
\hline Beroepssector & $\begin{array}{c}\text { intern mobiel } \\
\%\end{array}$ & $\begin{array}{c}\text { sector in } \\
\%\end{array}$ & $\begin{array}{c}\text { sector uit } \\
\%\end{array}$ \\
\hline Pedagogische beroepen & 2 & 1 & 1 \\
Culturele beroepen & 5 & 1 & 5 \\
Agrarische beroepen & 2 & 2 & 2 \\
Technische en industrieberoepen & 3 & 1 & 1 \\
Transportberoepen & 3 & 3 & 2 \\
Medische en paramedische beroepen & 3 & 0 & 1 \\
Economisch-administratieve beroepen & 4 & 1 & 1 \\
Informaticaberoepen & 4 & 2 & 0 \\
Sociaal-culturele beroepen & 3 & 1 & 2 \\
Verzorgende en dienstverlenende beroepen & 5 & 6 & 2 \\
Openbare orde- en veiligheidsberoepen & 2 & 1 & 1 \\
Totaal & 4 & & \\
\hline
\end{tabular}

Bron: SEP '94-'96/ROA

\subsection{Instroom op de arbeidsmarkt}

Naast de baanmobiliteit worden er nog twee 'soorten' instroom op de arbeidsmarkt onderscheiden. Dat zijn enerzijds de schoolverlaters en anderzijds de herintreders. Schoolverlaters zijn mensen die hun opleiding afgerond hebben, en zich daadwerkelijk aanbieden als werkzoekende op de arbeidsmarkt. Herintreders zijn mensen die gaan werken vanuit een situatie van non-participatie: zij waren weliswaar niet in opleiding, maar hadden ook geen werk. Herintreders zijn dus mensen die voordat zij weer gingen werken ofwel werkloos waren, ofwel buiten de arbeidsmarkt stonden. Bij het bepalen van de arbeidsmarktperspectieven voor schoolverlaters op middellange termijn wordt door het ROA altijd aangenomen dat schoolverlaters 'voor herintreders gaan'. Het blijkt dat er een grote instroom van herintreders is geweest in de afge- 
lopen jaren. Dit zou een reactie kunnen zijn op het bestaan van tekorten. Het zou echter ook zo kunnen zijn dat voor sommige functies herintreders voor de werkgever een beter alternatief vormen dan schoolverlaters. In deze paragraaf zal een overzicht gegeven worden van de instroom van schoolverlaters en herintreders, waarin geprobeerd zal worden deze aspecten nader te belichten.

\section{Instroom van schoolverlaters}

Bij aanbod op de arbeidsmarkt zijn we geneigd in eerste instantie aan schoolverlaters te denken. Deze groep maakt ook een zeer groot deel uit van het aanbod op de arbeidsmarkt. De meeste 'nieuwe' kennis komt de arbeidsmarkt op door schoolverlaters: hun schoolse kennis is tenslotte veel nieuwer dan die van andere werkenden. De vraag hoe groot de instroom van schoolverlaters is, wordt voor een groot deel bepaald door het aantal mensen dat nu een opleiding volgt, en de verwachte duur van deze opleiding. De mensen die nu 'in de pijplijn zitten' zijn op een gegeven moment afgestudeerd, en zullen op een of andere manier toetreden op de arbeidsmarkt. De instroom op de arbeidsmarkt hangt echter ook af van het aantal mensen dat aansluitend aan hun opleiding een volgende opleiding gaat volgen. Deze mensen stellen - al dan niet in reactie op de situatie op de arbeidsmarkt - hun toetreding nog een aantal jaren uit.

Uiteraard is de opleidingsherkomst van de instromende schoolverlaters van groot belang voor hun mogelijkheden op de arbeidsmarkt. Met welke opleidingsachtergrond dienen deze 'nieuwkomers op de arbeidsmarkt' zich aan? Tabel 3.12 toont op basis van het SEP - de verdeling van de instroom van schoolverlaters over de opleidingsniveaus per beroepssector. Zoals in de laatste regel van deze tabel te zien is, wordt het merendeel van de instroom van schoolverlaters gevormd door de schoolverlaters van het middelbare onderwijs (HAVONWO en MBO) en het HBO. Ongeveer $80 \%$ van de instroom heeft haar oorsprong in deze opleidingsniveaus en voor werkgevers is dit dus de voornaamste herkomst van nieuwkomers. Het VMBO levert iets meer dan $10 \%$ van de instroom van schoolverlaters. De twee 'buitencategorieën' Basisonderwijs en WO vormen de bron van de resterende $9 \%$ van de instroom van schoolverlaters.

De groep schoolverlaters met uitsluitend Basisonderwijs is relatief groot, en moet waarschijnlijk toegeschreven worden aan de uitval in het VMBO en het MBO. Als mensen een opleiding verlaten zonder deze met een diploma afgesloten te hebben, betekent dit dat hun hoogst voltooide opleiding het Basisonderwijs is. De laatste regel in tabel 3.12 laat zien dat het aantal schoolverlaters dat de arbeidsmarkt betreedt onder het niveau van de 'startkwalificatie' nog vrij groot is (15\%). Dit is een bron van zorg, gegeven hun perspectieven op de langere termijn. Merk op dat schoolverlaters die geen baan hebben kunnen vinden na hun opleiding in deze tabel niet meegenomen zijn.

Vanzelfsprekend is niet alleen de herkomst maar ook de precieze bestemming van de instroom van schoolverlaters op de arbeidsmarkt van belang. Personen met dezelfde opleidingsachtergrond hoeven immers niet op dezelfde plaats terecht te 
komen. Sommige opleidingen zijn specialistisch opgezet en bereiden hun schoolverlaters voor op een bepaald beroep, maar over het algemeen zijn opleidingen algemener. Dit geldt met name voor opleidingen op de lagere niveaus, die veelal vanuit een sterk algemeen karakter zijn opgezet en bedoeld zijn om schoolverlaters af te leveren die ofwel breed inzetbaar zijn of eenvoudig kunnen doorstromen naar een meer specialistische vervolgopleiding.

De eerste kolom in tabel 3.12 geeft aan hoe de verdeling van de schoolverlaters over de diverse beroepssectoren is. Het is te zien dat de grootste groep schoolverlaters de arbeidsmarkt betreedt in de verzorgende en dienstverlenende beroepen. Deze beroepssector neemt $31 \%$ van de instroom aan schoolverlaters op. Dit is erg veel als bedacht wordt dat op dit moment ca. $20 \%$ van de beroepsbevolking in deze sector werkzaam is ${ }^{7}$. Weliswaar vertoonde deze sector de afgelopen jaren een groeiende werkgelegenheid, maar die groei was nauwelijks groter dan het gemiddelde (zie ROA, 1999a). De grote behoefte aan schoolverlaters wordt dus veroorzaakt door de grote vervangingsvraag die ontstaat als gevolg van de grote uitstroom van personeel dat vervangen moet worden (zie ook tabel 3.5). De twee grote sectoren van de economisch-administratieve beroepen en de technische en industrieberoepen vormen de bestemmingssector voor respectievelijk $20 \%$ en $22 \%$ van de instroom van schoolverlaters. De andere - kleinere - beroepssectoren bieden minder werk voor instromende schoolverlaters. Vanwege het relatief kleine aantal schoolverlaters in SEP kunnen er voor de sociaal-culturele beroepen geen cijfers over schoolverlaters in deze beroepssector getoond worden.

Ook geeft tabel 3.12 inzicht in het opleidingsniveau van de schoolverlaters die werk vinden in de diverse beroepssectoren. Hieruit valt op te maken dat sommige beroepssectoren zich richten op schoolverlaters van een bepaald niveau, terwijl andere beroepssectoren juist werk bieden aan schoolverlaters van verschillende niveaus. Zo lijkt er in de agrarische beroepen voornamelijk werk te bestaan voor schoolverlaters met een MBO-achtergrond. Voorbeelden van beroepssectoren waarin juist schoolverlaters vanuit meerdere opleidingsniveaus terecht kunnen, zijn de medische en paramedische beroepen, en de economisch-administratieve beroepen, die schoolverlaters van alle niveaus kunnen gebruiken. Dit wordt voornamelijk veroorzaakt door het feit dat deze laatste drie beroepssectoren werk bieden aan zowel specialistisch opgeleiden, als ook aan meer algemeen opgeleid ondersteunend personeel.

Afgezien van de 'specialisatiegraad' van de bestemmingssector, geeft tabel 3.12 ook een indicatie van het aantal beroepssectoren waar schoolverlaters gezien hun opleidingsniveau in terecht kunnen. Zo toont het relatief kleine aantal beroepssectoren waarin schoolverlaters van het WO zijn vertegenwoordigd aan dat lang niet alle beroepssectoren behoefte hebben aan wetenschappelijk opgeleid personeel. Dit hoeft natuurlijk geen verwondering te wekken gezien de aard van het werk in deze sectoren, dat vooral technisch van aard is. De opleidingsniveaus welke de grootste

7. In tabel 4.2 van dit rapport zijn aantallen werkenden per beroepssector opgenomen. 
verspreiding te zien geven, zijn daarentegen de meer voorbereidende dan wel praktijkgerichte opleidingsniveaus VMBO, HAVO/NWO/MBO en HBO. Aan deze niveaus is binnen vrijwel alle beroepssectoren behoefte.

Tabel 3.12

Bestemming van de instroom van schoolverlaters naar opleidingsachtergrond

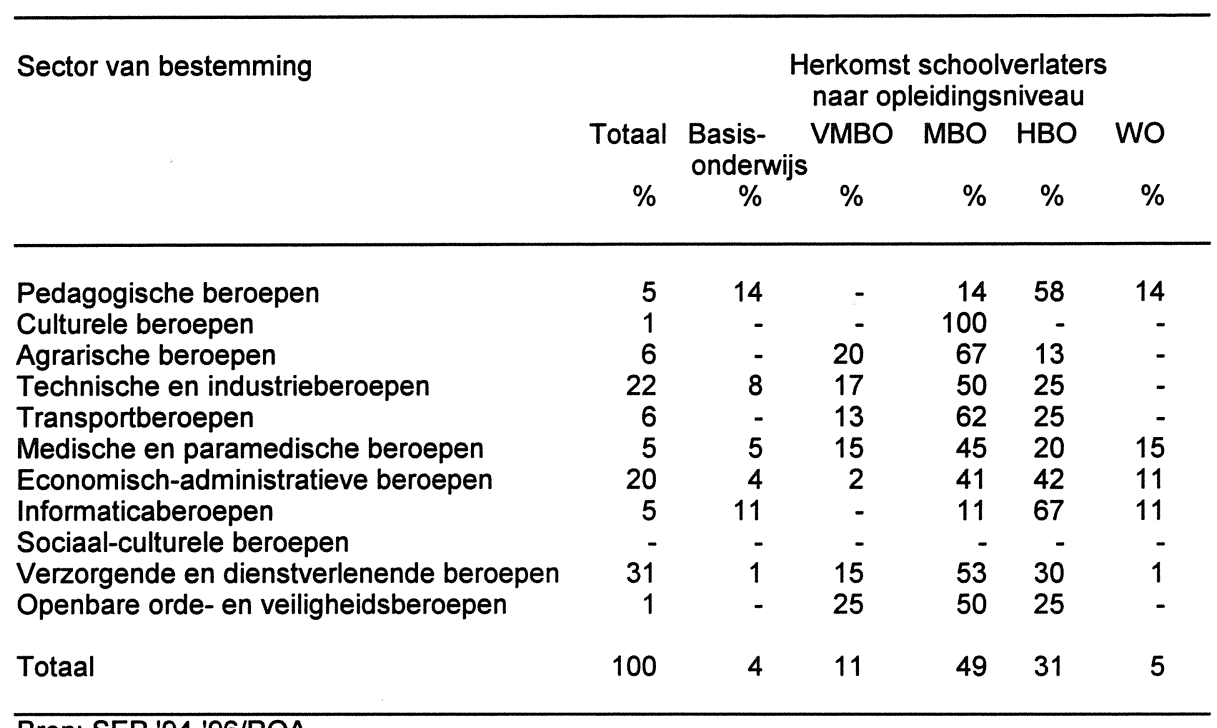

Bron: SEP '94-'96/ROA

Naast de opleidingsachtergrond zijn mogelijk ook persoonlijke kenmerken van de schoolverlaters van belang voor hun arbeidsmarktsituatie. Ter illustratie daarvan wordt in tabel 3.13 weergegeven hoe de opbouw van de groep schoolverlaters is naar leeftijd en geslacht. Het is te zien dat bijna $90 \%$ van de schoolverlaters de arbeidsmarkt betreedt voordat men 25 is. De overige $12 \%$ van de schoolverlaters is ouder dan 25. Een zeer klein deel van degenen die een opleiding afronden is zelfs ouder dan 40, maar hier is ongetwijfeld sprake van mensen die op latere leeftijd een tweede opleiding zijn gaan volgen. Behalve de opbouw naar leeftijd, is in de tabel ook de opbouw naar geslacht te zien. Het is te zien dat in de aangegeven jaren meer mannen dan vrouwen de arbeidsmarkt betreden hebben. Als vervolgens gekeken wordt naar de leeftijdsopbouw van de mannelijke en de vrouwelijke schoolverlaters valt op dat in de eerste twee leeftijdscategorieën, welke dus de overgrote groep schoolverlaters opmaken, de verhouding man-vrouw vrijwel gelijk is aan de overall man-vrouw verhouding: rond de $55 \%$ van de nieuwe instroom op de arbeidsmarkt is man, tegenover ongeveer $45 \%$ vrouw. Wat echter opvalt is dat deze min of meer fifty-fifty man-vrouw verdeling niet meer opgaat voor de oudere cohorten, daar vormen de vrouwen een groter aandeel gaan vormen van de instroom. Enerzijds is dit het gevolg van langer studeren en anderzijds wordt dit veroorzaakt door vrouwen die zich om- dan wel bijscholen na hun initiële opleiding. Deze laatste groep zal voor een groot deel bestaan uit 'tweede-kans'-onderwijs, en op termijn waarschijnlijk kleiner worden. Gemiddeld genomen zijn vrouwelijke schoolverlaters op het moment dat ze de arbeidsmarkt betreden dus iets ouder dan de mannelijke schoolverlaters. 
Tabel 3.13

Instroom van schoolverlaters naar leeftijd en geslacht

\begin{tabular}{lccc}
\hline Leeftijd & $\begin{array}{c}\text { Totaal } \\
\%\end{array}$ & $\begin{array}{c}\text { Verdeling naar geslacht } \\
\text { Man } \\
\%\end{array}$ & $\begin{array}{c}\text { Vrouw } \\
\%\end{array}$ \\
\hline $15-20$ & 56 & 54 & 46 \\
$20-25$ & 32 & 56 & 44 \\
$25-30$ & 5 & 38 & 62 \\
$30-35$ & 4 & 30 & 70 \\
$35-40$ & 1 & 33 & 67 \\
ouder dan 40 & 2 & 50 & 50 \\
Totaal & 100 & 53 & 47 \\
\hline
\end{tabular}

Bron: SEP '94-'96/ROA

\section{Instroom van herintreders}

Het blijkt uit longitudinale data dat de instroom van herintreders op de arbeidsmarkt groot is. Zeker de afgelopen jaren, toen de krapte op de arbeidsmarkt groot was, vormden de schoolverlaters niet het enige nieuwe aanbod van werkenden op de arbeidsmarkt. Er was daarnaast ook sprake van een grote intrede van herintreders. In deze paragraaf zal de samenstelling van de groep herintreders getoond worden.

Tabel 3.14 laat, analoog aan tabel 3.12, zien welke opleidingsachtergrond de herintreders hebben. De tabel laat zien dat de herintreders relatief laag geschoold zijn. Bijna de helft (48\%) beschikt niet over een zogenaamde 'startkwalificatie' en is ongeschoold ofwel laag geschoold. Ondanks het feit dat er altijd gezegd wordt dat een dergelijke startkwalificatie noodzakelijk is, is er blijkbaar toch wel ruimte op de arbeidsmarkt voor mensen die niet over deze kwalificatie beschikken. De vraag is alleen wat voor hen het perspectief op langere termijn is, zeker gegeven de kans op baanverlies voor laaggeschoolden zoals dat in de vorige paragrafen getoond is.

De eerste kolom in tabel 3.14 geeft de bestemming van de herintreders aan: het is te zien dat dezelfde drie beroepssectoren die het merendeel van de schoolverlaters werk boden, ook de meeste herintreders opnemen. De verzorgende en dienstverlenende beroepen, de economisch-administratieve beroepen en de technische en industrieberoepen vormen tezamen de bestemming voor liefst $73 \%$ van alle instromende herintreders. De andere beroepssectoren nemen relatief weinig herintreders aan. Dit is niet verwonderlijk aangezien de herintreders over het algemeen relatief laag zijn opgeleid en daardoor minder geschikt zullen worden gevonden voor de meer specialistische beroepen. Ook in sectoren met grote technologische veranderingen zullen mensen met een relatief oude opleiding moeilijker aan het werk komen. Werkgevers in deze sectoren zullen zich dus eerder bedienen van het aanbod van schoolverlaters met nieuwe en specialistische kennis. 
Tabel 3.14

Bestemming van de instroom van herintreders naar opleidingsachtergrond

\begin{tabular}{|c|c|c|c|c|c|c|}
\hline \multirow[t]{3}{*}{ Sector van bestemming } & \multicolumn{6}{|c|}{$\begin{array}{l}\text { Herkomst schoolverlaters } \\
\text { naar opleidingsniveau }\end{array}$} \\
\hline & \multicolumn{2}{|c|}{$\begin{array}{l}\text { Totaal Basis- } \\
\text { onderwijs }\end{array}$} & VMBO & MBO & HBO & Wo \\
\hline & $\%$ & $\%$ & $\%$ & $\%$ & $\%$ & $\%$ \\
\hline Pedagogische beroepen & 6 & - & 11 & 11 & 67 & 11 \\
\hline Culturele beroepen & 2 & - & - & 33 & 67 & - \\
\hline Agrarische beroepen & 4 & 17 & 50 & 33 & - & - \\
\hline Technische en industrieberoepen & 16 & 29 & 33 & 33 & 5 & - \\
\hline Transportberoepen & 5 & 29 & 57 & 14 & - & - \\
\hline Medische en paramedische beroepen & 5 & - & 29 & 71 & - & - \\
\hline Economisch-administratieve beroepen & 21 & 9 & 24 & 58 & 9 & \\
\hline Informaticaberoepen & 2 & - & - & 100 & - & - \\
\hline Sociaal-culturele beroepen & 2 & - & 33 & - & 33 & 33 \\
\hline Verzorgende en dienstverlenende beroepen & 38 & 17 & 40 & 33 & 9 & 2 \\
\hline Openbare orde- en veiligheidsberoepen & - & - & - & - & - & - \\
\hline Totaal & 100 & 15 & 33 & 38 & 12 & 2 \\
\hline
\end{tabular}

Bron: SEP '94-'96/ROA

Tabel 3.15

Instroom van herintreders naar leeftijd en geslacht

\begin{tabular}{|c|c|c|c|}
\hline \multirow{2}{*}{ Leeftijd } & \multirow{2}{*}{$\begin{array}{c}\text { Totaal } \\
\%\end{array}$} & \multicolumn{2}{|c|}{ Verdeling naar geslacht } \\
\hline & & $\begin{array}{r}\text { Man } \\
\%\end{array}$ & $\begin{array}{c}\text { Vrouw } \\
\%\end{array}$ \\
\hline $\begin{array}{l}15-20 \\
20-25 \\
25-30 \\
30-35 \\
35-40 \\
40-45 \\
\text { ouder dan } 45\end{array}$ & $\begin{array}{r}4 \\
13 \\
19 \\
19 \\
22 \\
12 \\
11\end{array}$ & $\begin{array}{l}17 \\
45 \\
38 \\
17 \\
29 \\
21 \\
25\end{array}$ & $\begin{array}{l}83 \\
55 \\
62 \\
83 \\
71 \\
79 \\
75\end{array}$ \\
\hline Totaal & 100 & 27 & 73 \\
\hline
\end{tabular}

Bron: SEP '94-'96/ROA

Tabel 3.15 geeft de verdeling van de herintreders naar leeftijd en geslacht aan. Het blijkt dat de meeste herintreders ouder zijn dan 30, hoewel bijna eenderde jonger is dan 30 . Er blijkt zelfs een groep relatief oude herintreders te zijn: $11 \%$ is namelijk ouder dan 45. Als oudere werkzoekenden over de juiste opleiding of ervaring beschikken, blijken er voor hen nog wel mogelijkheden te bestaan. Nadere analyse van de data leert dat vooral de agrarische sector nog mogelijkheden blijkt te bieden voor oudere werknemers. In de sector van de transportberoepen en de medische en paramedische beroepen waren er in de periode van 1994 tot 1997 echter nauwelijks mogelijkheden voor oudere herintreders. Wat vooral opvalt in tabel 3.15 is dat de meeste herintreders vrouwen zijn. Vooral in de leeftijdsgroep 30-35 zijn er slechts 
relatief weinig mannen. Dit correspondeert met de observatie dat in deze leeftijdscategorie ook relatief veel vrouwen de arbeidsmarkt verlaten. Het gevolg hiervan is wel dat lang niet alle sectoren kunnen putten uit de groep niet-participerenden om hun personeel uit te werven. Alleen de sectoren waarin deze vrouwen werkzaam waren - en dat mogelijk weer willen zijn - kunnen baat hebben bij het aantrekken van herintreders. Dit zijn dus sectoren zoals het onderwijs of de zorgsector.

\subsection{De relatieve positie van aanbieders op de arbeidsmarkt}

In de vorige paragrafen is stilgestaan bij de samenstelling van de groepen aanbieders op de arbeidsmarkt. Het is daarbij duidelijk geworden dat vacatures niet uitsluitend door schoolverlaters vervuld worden. Veel vacatures worden vervuld door mensen die al werkzaam waren, of door mensen die eerst 'langs de zijlijn' van de arbeidsmarkt stonden. Er zijn tal van redenen te bedenken waarom werkgevers de voorkeur geven aan anderen in plaats van aan schoolverlaters. Voor het vervullen van hogere functies zullen ze al snel geneigd zijn om ervaring als selectiecriterium te gebruiken. Daarnaast kan het zo zijn dat ze vacatures op een laag functieniveau hebben, waarvoor een oudere ongeschoolde werknemer voldoende is. De vraag blijft echter in hoeverre de relatief grote instroom van oudere relatief laag opgeleide herintreders een gevolg is van de heersende krapte op de arbeidsmarkt. Het is moeilijk om op basis van gerealiseerde stromen aan te geven wat de voorkeur van werkgevers is. Als ze liever een 'doorstromer' of een schoolverlater hebben, maar die niet kunnen vinden, dan moeten ze wel een herintreder nemen. In de voorgaande paragrafen zijn al tabellen gepresenteerd over de drie afzonderlijke groepen. In deze paragraaf wordt een overzicht gegeven van de samenstelling van de instroom naar herkomst, omdat dit mogelijk een indicatie geeft in welke sectoren er blijkbaar mogelijkheden liggen voor de drie groepen. In tabel 3.16 wordt per opleidingsniveau de verhouding weergegeven tussen de instroom uit de drie groepen aanbieders. De tabel laat nogmaals zien dat baanmobiliteit een belangrijk fenomeen is. Ruim de helft van de totale (bruto) instroom bestaat uit mensen die al elders werkzaam waren. Omdat deze instroom echter gepaard gaat met een even grote uitstroom, kan door deze baanwisselaars nooit een groei van het aantal banen gecreëerd worden. Hiervoor is een instroom van 'nieuwkomers' op de arbeidsmarkt nodig. De tabel laat zien dat de totale instroom van 'nieuwkomers' op de arbeidsmarkt voor de helft uit schoolverlaters $(21 \%)$ en voor de helft uit herintreders $(21 \%)$ bestaat. Dit geeft andermaal aan dat de herintreders een grote groep vormen, waarmee terdege rekening gehouden dient te worden bij het opstellen van adequate arbeidsmarktprognoses en het formuleren van een stromenmodel. De verhouding zoals genoemd doet zich echter niet voor op de afzonderlijke opleidingsniveaus. Zoals uit een vergelijking van de tabellen 3.12 en 3.14 ook al bleek, hebben de herintreders gemiddeld genomen een lager opleidingsniveau dan de schoolverlaters: bij de schoolverlaters beschikt $15 \%$ niet over een startkwalificatie, bij de herintreders is dit maar liefst $48 \%$. Dit heeft tot gevolg dat voor de vervulling van banen op een laag opleidingsniveau schoolverlaters nauwelijks een rol spelen. Voor deze banen worden veel baanwisselaars en herintreders aangenomen. Voor de hogere niveaus neemt het belang van de herintreders snel af, terwijl dat van de schoolverlaters toeneemt. Opvallend is wel het grote belang van baanwisselaars op het hoogste opleidings- 
niveau. Hier lijkt sprake te zijn van een relatief grote mobiliteit van werkenden, vergeleken met de groei van de werkgelegenheid op dit niveau. Uit de tabel blijkt ook dat het belang van schoolverlaters op het HBO-niveau het grootste is. Blijkbaar nemen op dit niveau werkgevers heel vaak een schoolverlater aan in plaats van een andere werkzoekende. Het gevolg van dit grote belang van schoolverlaters is dat knelpunten in de personeelsvoorziening hier het hardste gevoeld worden. Als er immers sprake is van veel baanmobiliteit zoals op het WO-niveau, zullen bij een gelijk personeelstekort vacatures voor de individuele werkgever veel minder lang duren, en zal de krapte zich veel meer vertalen in een hoog personeelsverloop dan in langdurig openstaande vacatures.

Tabel 3.16

Verhouding van de instroom per opleidingsniveau

\begin{tabular}{lccc}
\hline Opleidingsniveau & $\begin{array}{c}\text { Baanwisselaars } \\
\%\end{array}$ & $\begin{array}{c}\text { Schoolverlaters } \\
\%\end{array}$ & $\begin{array}{c}\text { Herintreders } \\
\%\end{array}$ \\
\hline Basisonderwijs & 56 & 10 & 35 \\
VMBO & 58 & 11 & 30 \\
MBO & 60 & 23 & 17 \\
HBO & 48 & 38 & 14 \\
WO & 73 & 19 & 8 \\
Totaal & 58 & 21 & 21 \\
\hline
\end{tabular}

Bron: SEP '94-'96/ROA

De voorgaande feiten lijken er op te duiden dat voor het oplossen van de eventueel bestaande knelpunten het vergroten van de participatie van ouderen of andere nietactieven een mogelijkheid zou kunnen zijn. Herintreders kunnen tenslotte een belangrijke wervingscategorie voor werkgevers vormen. De groep niet-participerenden is groot en vormt dus op het eerste gezicht een uitgelezen contingent waaruit men extra personeel zou kunnen aantrekken. Toch zal deze eerste indruk bijgesteld moeten worden, vanwege de lage opleidingsachtergrond van diegenen die nu nog langs de zijlijn staan. De vraag naar nieuwkomers richt zich tenslotte in toenemende mate op hoger opgeleiden. Het bevorderen van de arbeidsdeelname van deze groep - hoe men dit ook vorm zou willen geven - zal dus gepaard moeten gaan met een duidelijke inspanning. Het is misschien mogelijk om deze groep bij te scholen om op het gevraagde niveau te komen. Daar waar dat niet mogelijk is, zullen andere aanpassingen nodig zijn. In dat geval kan het toepassen van een zogenaamd 'cascademodel' wellicht betere perspectieven bieden voor het oplossen van knelpunten. Wanneer werkgevers hun vacatures op de hogere niveaus zouden kunnen opvullen door intern werknemers op te leiden, dan zou men de vacatures naar een lager niveau terug kunnen brengen. Ditzelfde kan misschien ook bereikt worden door binnen een bedrijf de taken zo over de medewerkers te verdelen dat hoger opgeleiden niet of nauwelijks ingezet worden om werkzaamheden te verrichten die ook door lager opgeleiden verricht kunnen worden ('functiesplitsing'). Ook hierdoor is het mogelijk om vacatures op een relatief laag niveau te creëren. De grote groep herintreders die zich op de arbeidsmarkt wil begeven, maar die een lage opleidingsachter- 
grond heeft, zou vervolgens voor de vervulling van deze vacatures geschikt kunnen zijn. Door gebruikmaking van een dergelijke aanpassingen door de werkgever is het mogelijk dat ook laag opgeleiden nog ingezet kunnen worden. Als gevolg daarvan hoeven hun arbeidsmarktkansen niet zo snel terug te lopen als men soms wel vreest. Het zou nuttig zijn om te weten of de grote instroom van lager opgeleiden die de afgelopen jaren heeft plaats gevonden het gevolg is van dergelijke aanpassingsprocessen van werkgevers. In hoeverre bij- of omscholing de scholingsachterstand kan wegwerken en of laag opgeleiden gebaat zijn bij het toepassen van het cascademodel of andere aanpassingen door de werkgevers, is sterk afhankelijk van de mogelijkheden binnen de verschillende beroepssectoren.

Tabel 3.17

Verhouding van de instroom per beroepssector

\begin{tabular}{lccc}
\hline Beroepssector & $\begin{array}{c}\text { Baanwisselaars } \\
\%\end{array}$ & $\begin{array}{c}\text { Schoolverlaters } \\
\%\end{array}$ & $\begin{array}{c}\text { Herintreders } \\
\%\end{array}$ \\
\hline Pedagogische beroepen & 48 & 22 & 29 \\
Culturele beroepen & 64 & 9 & 27 \\
Agrarische beroepen & 50 & 30 & 20 \\
Technische en industrieberoepen & 61 & 23 & 16 \\
Transportberoepen & 58 & 23 & 19 \\
Medische en paramedische beroepen & 60 & 22 & 17 \\
Economisch-administratieve beroepen & 68 & 16 & 12 \\
Informaticaberoepen & 60 & 28 & 17 \\
Sociaal-culturele beroepen & 83 & - & 29 \\
Verzorgende en dienstverlenende beroepen & 47 & 24 & - \\
Openbare orde- en veiligheidsberoepen & 67 & 33 & 21 \\
Totaal & & 21 & \\
\hline
\end{tabular}

Bron: SEP '94-'96/ROA

Net zoals er verschillen blijken te zijn tussen opleidingsniveaus in het aandeel van de drie groepen, blijkt dit ook zo te zijn tussen sectoren. Tabel 3.17 geeft de instroomverhouding van de drie groepen per beroepssector. Op basis van tabel 3.16 valt te verwachten dat schoolverlaters van groot belang zijn voor sectoren waar het HBO zwaar vertegenwoordigd is, terwijl de herintreders veel belangrijker zijn voor sectoren waar laag en ongeschoold werk voorkomt. Dit patroon is echter in tabel 3.17 niet terug te vinden. Er is veel duidelijker een verband te zien met het aantal vrouwen dat in een sector werkzaam is: hoe meer vrouwen er werkzaam zijn, des te belangrijker de herintreders zijn voor de personeelsvoorziening. Zo kennen de pedagogische beroepen, de culturele beroepen en de verzorgende en dienstverlenende beroepen een instroom die voor bijna eenderde uit herintreders bestaat. Sectoren die te maken hebben met relatief nieuwe kennis en grote technologisch veranderingen maken daarentegen veel meer gebruik van schoolverlaters: zo komt bij de informaticaberoepen eenderde van de instroom van school.

Bij deze vergelijkingen tussen de drie groepen dringt zich wel de vraag op of werkgevers herintreders in dienst nemen voor het verrichten van laag- en ongeschoold werk waarvoor ze geen schoolverlaters meer kunnen vinden, of dat ze noodge- 
dwongen (te) laag geschoolde werknemers in dienst nemen omdat er geen schoolverlaters of andere werkzoekenden met een hoger opleidingsniveau beschikbaar zijn. Deze vraag is niet te beantwoorden op basis van de huidige cijfers, maar is wel van wezenlijk belang. Als herintreders alleen maar gewenst zijn vanwege hun lage opleiding (en dus relatief lage kosten) wordt hun positie ten opzichte van schoolverlaters slechter als ze een hogere opleiding afronden: ze worden dan namelijk veel duurder dan schoolverlaters omdat ze ouder zijn. Als herintreders in dienst genomen worden bij gebrek aan schoolverlaters met de juiste opleiding, dan wordt hun positie op de arbeidsmarkt juist beter met een hogere opleiding, omdat ze in dat geval beschikken over de door de werkgever gevraagde kwalificaties.

\subsection{Samenvatting}

In dit hoofdstuk wordt een beeld geschetst van de stromen die zich op de arbeidsmarkt voordoen. Het vergelijken van aantallen werkenden op twee momenten in een bepaald beroep, of met een bepaalde opleiding, geeft weliswaar een goed inzicht in de netto verschuivingen die op de arbeidsmarkt plaatsvinden, maar geeft geen inzicht in de achterliggende dynamiek die deze netto verschuivingen veroorzaakt.

Omdat de prognoses tot stand gekomen zijn met gebruikmaking van een model dat juist deze dynamiek tracht te beschrijven en wenst te relateren aan kenmerken van individuen, is het zinvol om voordat deze prognoses getoond worden een beeld te schetsen van de mobiliteit op de arbeidsmarkt. Inzicht in deze stromen helpt enerzijds om de prognoses beter te interpreteren, maar geeft aan de andere kant ook een idee waar eventuele knelpunten door ontstaan. Is het een hoge uitstroom van personeel dat een tekort veroorzaakt, of juist een achterblijvend aanbod? En als het een hoge uitstroom is, wat kan dan de oorzaak zijn van die uitstroom? Op deze manier kan de informatie uit dit hoofdstuk bijdragen aan een beter begrip van de verschillen tussen beroepen en opleidingen, en dus de aanzet zijn tot een meer gerichte analyse van mogelijke oplossingen voor de problemen in de diverse sectoren.

De totale uitstroom is de eerste stroom die van belang is. Deze wordt ook wel aangeduid met de term bruto vervangingsvraag. Afgezien van de groei van de werkgelegenheid is dit de hoeveelheid nieuwe werknemers die een werkgever zal moeten zien te vinden. Het blijkt dat de uitstroom zeer sterk gerelateerd is aan leeftijd en geslacht van de betrokken werknemers. Na een aanvankelijk hoge uitstroomkans voor jongeren als gevolg van o.a. zoekmobiliteit, loopt de uitstroomkans terug naarmate men ouder wordt. Pas zodra de VUT of pensioen weer in zicht komen, loopt de uitstroomkans weer op. Daarnaast is er een duidelijk verschil tussen mannen en vrouwen: De uitstroomkans van vrouwen is bijna twee keer zo groot als die van mannen. De oorzaak daarvan moet worden gezocht in het zogenaamde 'kinderdal': vrouwen onderbreken hun loopbaan om zich te wijden aan het krijgen en opvoeden van kinderen. Juist in die leeftijdscategorie (35-40 jaar) is het verschil in uitstroomkans tussen mannen en vrouwen 11 procentpunt. Behalve een verschil naar leeftijd en geslacht is er ook een verschil in uitstroomkans naar opleidingsniveau. De mobiliteit is het laagste op de laagste opleidingsniveaus. De hogere opleidings- 
niveaus kennen een hogere uitstroom, waarbij die op het WO-niveau iets lager is dan die op het HBO-niveau.

Als men uitstroomt zijn er drie mogelijkheden, ofwel men gaat naar een andere baan (doorstroom), ofwel men wordt niet-actief (werkloos of niet-participerend), ofwel men gaat (terug) naar school. De doorstroom blijkt de belangrijkste bestemming: van de totale uitstroom gaat bijna de helft naar een andere baan, wordt iets meer dan $10 \%$ werkloos, $34 \%$ verlaat de arbeidsmarkt, terwijl ca. $10 \%$ aan een opleiding begint. Deze verhouding is echter in hoge mate gerelateerd aan de kenmerken van de betrokken persoon. Hoe ouder men is, des te groter de kans dat men de arbeidsmarkt verlaat. $\mathrm{Er}$ is ook een duidelijk verschil tussen mannen en vrouwen: het percentage van de mannen en vrouwen die van arbeidsmarktpositie veranderen dat werkloos of scholier wordt is ongeveer gelijk, maar mannen gaan veel vaker naar een andere baan, terwijl vrouwen - als zij van positie veranderen - veel vaker de arbeidsmarkt definitief verlaten of zich in ieder geval voor langere tijd terugtrekken van de arbeidsmarkt. Naast leeftijd en geslacht blijkt het opleidingsniveau een belangrijke factor te zijn: de baanmobiliteit is aanzienlijk hoger voor hoger opgeleiden, terwijl het percentage laagopgeleiden dat de arbeidsmarkt verlaat relatief hoog is. De uitstroom naar werkloosheid is op alle opleidingsniveaus ongeveer gelijk. Het valt op dat terugkeer naar een opleiding eigenlijk alleen voor mensen op het VMBO-niveau een optie lijkt. Voor zowel de lager als de hoger opgeleiden is het volgen van een opleiding nadat men al gewerkt heeft blijkbaar geen optie meer. Dit suggereert dat mensen op het VMBO-niveau die hun baan verliezen beseffen dat aanvullende scholing hun kansen op een baan vergroot omdat hun huidige niveau tekort schiet. Voor de ongeschoolden zal het volgen van een aanvullende opleiding veel moeilijker zijn, terwijl voor de hoog opgeleiden een aanvullende opleiding nauwelijks rendement zal hebben in termen van baankansen, waardoor op deze niveaus het volgen van scholing veel minder voorkomt.

Behalve de effecten van de persoonlijke kenmerken op het mobiliteitspatroon, zijn er ook verschillen tussen de beroepssectoren. De uitstroomkansen verschillen sterk tussen de verschillende beroepssectoren. De pedagogische beroepen en de medische en paramedische beroepen hebben met $7 \%$ de laagste uitstroomkans, terwijl de verzorgende en dienstverlenende beroepen met $19 \%$ een relatief hoge uitstroomkans hebben. Er bestaan daarnaast ook grote verschillen tussen de beroepssectoren in de uitstroombestemming. Bij de pedagogische beroepen, de agrarische beroepen en de openbare orde- en veiligheidsberoepen komt de laagste doorstroom voor: in deze sectoren verlaat het grootste deel van de uitstromers de arbeidsmarkt. Bij de culturele beroepen en de medische en paramedische beroepen is de doorstroom het grootst: ruim $60 \%$ van de uitstroom vertrekt naar een andere baan. Deze doorstroom gaat echter niet noodzakelijkerwijs naar een baan binnen dezelfde beroepssector.

In geval van baanmobiliteit blijkt de meerderheid - ongeveer driekwart - een volgende baan binnen dezelfde beroepssector te vinden. De vraag of men in geval van baanmobiliteit naar een andere baan in dezelfde sector gaat, of juist naar een baan in een andere sector, hangt ook van kenmerken van de betrokkenen af. Zo veranderen jongeren relatief vaak van sector - waarschijnlijk als gevolg van zoekmobiliteit 
- terwijl dat op middelbare leeftijd veel minder gebeurt. De oudere baanwisselaars tussen de 40 en de 45 daarentegen veranderen weer relatief vaker van sector. $\mathrm{Er}$ is ook hier een verband met het opleidingsniveau: Zowel de ongeschoolden als de hoogopgeleiden veranderen relatief vaak van sector, terwijl de niveaus daartussen in driekwart van de gevallen mobiel zijn binnen hun eigen beroepssector. Tot slot lijkt de ene sector veel beter in staat zijn personeel vast te houden dan de andere: van de mensen die werkzaam waren in de informaticaberoepen is vrijwel iedereen mobiel binnen de sector. Ook voor de medische en paramedische beroepen, de economisch-administratieve beroepen en de verzorgende en dienstverlenende beroepen blijt de grote meerderheid van de baanwisselaars binnen de sector. Deze mensen blijven natuurlijk niet noodzakelijkerwijs in hetzelfde beroep werkzaam: Zo kent bijvoorbeeld de zorgsector beroepen waarvoor het zeer lastig blijkt om werknemers vast te houden. Er zijn ook sectoren die relatief veel mensen kwijtraken aan andere sectoren: bij de culturele beroepen blijkt slechts de helft binnen de beroepssector te blijven. Voor alle sectoren of beroepen waar men problemen heeft met het vasthouden van personeel is het van belang om meer kennis te verkrijgen over de vraag waarom mensen kiezen voor een baan in een andere sector.

Een laatste aspect van de doorstroom dat met name voor het scholings- en bemiddelingsbeleid binnen een sector van belang kan zijn, is de vraag in hoeverre baanmobiliteit binnen de sector ook gepaard gaat met een stijging van het functieniveau. Als baanmobiliteit in veel gevallen gepaard gaat met zo'n stijging kan dat er op duiden dat voor het vervullen van hogere beroepen in die sector ervaring binnen de sector gewenst dan wel noodzakelijk is. Als er dan tekorten op het niveau van deze hogere beroepen zijn, dan is het bijscholen van schoolverlaters of herintreders misschien niet altijd de beste manier om deze tekorten op te lossen. In dat geval moet men juist de doorgroei binnen de sector trachten te bevorderen teneinde de krapte bij de hogere functies te doen afnemen. Dit heeft dan tegelijk tot gevolg dat er een verschuiving optreedt in de 'kwaliteit' van de externe vacatures: de eisen die men gaat stellen aan mensen die van buiten de sector komen zullen lager worden. Hierdoor krijgen de werkgevers in geval van personeelsschaarste meer mogelijkheden om uit te wijken naar mensen met een lagere of minder goed aansluitende opleiding. Een dergelijk doorgroeimodel waarbinnen de kwaliteit van externe vacatures verlaagd wordt, wordt een cascademodel genoemd (zie o.a. Hofman, 1991). Als baanmobiliteit niet met een stijging van het functieniveau gepaard gaat, dan is ervaring binnen de sector blijkbaar niet nodig om binnen de sector naar een hoger functieniveau door te groeien. In dat geval kan ook scholing van andere werkzoekenden mogelijk een belangrijke bijdrage leveren aan het verminderen van knelpunten bij de hogere beroepsniveaus binnen een sector. Het voor dit rapport gebruikte databestand leverde helaas onvoldoende informatie om dit soort processen betrouwbaar mee te kunnen beschrijven. Nader onderzoek naar mobiliteit gekoppeld aan stijging van het functieniveau is dus noodzakelijk.

Tegenover de uitstroom van werkenden staat de instroom van arbeidsaanbieders. De instroom wordt gevormd door drie groepen: de baanwisselaars, de schoolverlaters en de herintreders. De baanwisselaars zijn hierboven als onderdeel van de uitstroom al ter sprake gekomen. Schoolverlaters verschillen relatief weinig in leeftijd 
en overige kenmerken. Eigenlijk verschillen ze uitsluitend in hun opleidingsachtergrond. Het merendeel van de instroom van schoolverlaters wordt gevormd door de schoolverlaters van het middelbare onderwijs (HAVONWO en MBO) en het HBO. Ongeveer $80 \%$ van de instroom heeft haar oorsprong in deze opleidingsniveaus en voor werkgevers is dit dus de voornaamste herkomst van nieuwkomers. Het VMBO levert iets meer dan $10 \%$ van de instroom van schoolverlaters. Daarnaast blijkt er een relatief grote groep schoolverlaters te zijn die het Basisonderwijs als hoogst voltooide opleiding hebben. Deze groep moet waarschijnlijk toegeschreven worden aan de uitval in het VMBO en het MBO. Als mensen een opleiding verlaten zonder deze met een diploma afgesloten te hebben, betekent dit dat hun hoogste voltooide opleiding het Basisonderwijs is. Het aantal schoolverlaters dat onder het niveau van de 'startkwalificatie' de arbeidsmarkt betreedt, is mede daardoor vrij groot (15\%). Dit is een bron van zorg gegeven hun perspectieven op de langere termijn. Het aanbod van 'nieuwkomers' op de arbeidsmarkt wordt naast schoolverlaters gevormd door herintreders. De groep herintreders blijkt veel minder homogeen dan de groep schoolverlaters. Er zijn veel grotere verschillen in leeftijd en opleidingsniveau. Gemiddeld genomen zijn de herintreders aanzienlijk ouder dan de schoolverlaters, en zijn er relatief veel vrouwen in deze groep. Daarnaast blijkt er ook een groot verschil in opleidingsniveau tussen beide groepen: bijna de helft van de herintreders beschikt niet over een zogenaamde 'startkwalificatie' en is ongeschoold ofwel laag geschoold. Ondanks het feit dat er altijd gezegd wordt dat een dergelijke startkwalificatie noodzakelijk is, is er blijkbaar toch wel ruimte op de arbeidsmarkt voor de mensen die niet over deze kwalificatie beschikken. De vraag is alleen wat voor hen het perspectief op langere termijn is, zeker gegeven de kans op baanverlies voor oudere laaggeschoolden.

Gezien de omvang van de drie groepen kan gesteld worden dat er blijkbaar voor alle drie ruimte en mogelijkheden zijn op de arbeidsmarkt. Ruim de helft van de instroom $(58 \%)$ bestaat uit mensen die al elders werkzaam waren. Omdat deze bruto instroom echter gepaard gaat met een even grote bruto uitstroom, kan door de baanwisselaars nooit een groei van het aantal banen gecreëerd worden. Hiervoor is een instroom van 'nieuwkomers' op de arbeidsmarkt nodig. De totale instroom van 'nieuwkomers' op de arbeidsmarkt bestaat voor de helft uit schoolverlaters $(21 \%)$ en voor de helft uit herintreders $(21 \%)$. De vraag daarbij is natuurlijk of de relatief belangrijke positie van de herintreders hierin het gevolg is van de voorkeuren van de werkgevers of dat ze 'noodgedwongen' is als gevolg van de heersende krapte op de arbeidsmarkt. Er zijn tal van redenen te bedenken waarom werkgevers de voorkeur geven aan anderen in plaats van aan schoolverlaters. Voor het vervullen van hogere functies zullen ze al snel geneigd zijn om ervaring als selectiecriterium te gebruiken. Daarnaast kan het zo zijn dat ze vacatures op een laag functieniveau hebben waarvoor een oudere ongeschoolde werknemer voldoende is.

De genoemde verhouding tussen de drie groepen aanbieders doet zich echter niet voor op de afzonderlijke opleidingsniveaus. Voor de vervulling van banen op een laag opleidingsniveau (ongeschoold werk en banen waarvoor een opleiding op VMBO-niveau voldoende is) blijken schoolverlaters nauwelijks een rol spelen. Voor deze banen worden veel baanwisselaars en herintreders aangenomen. Voor de 
hogere niveaus neemt het belang van de herintreders snel af, terwijl dat van de schoolverlaters toeneemt. Opvallend is wel het grote belang van baanwisselaars op het hoogste opleidingsniveau. Hier lijkt sprake te zijn van een relatief grote mobiliteit van werkenden, vergeleken met de groei van de werkgelegenheid op dit niveau. $\mathrm{Er}$ zijn ook verschillen tussen sectoren: hoe meer vrouwen er in een sector werkzaam zijn, des te belangrijker de herintreders zijn voor de personeelsvoorziening. Zo kennen de pedagogische beroepen, de culturele beroepen en de verzorgende en dienstverlenende beroepen een instroom die voor bijna eenderde uit herintreders bestaat. Sectoren die te maken hebben met relatief nieuwe kennis en grote technologisch veranderingen daarentegen maken veel meer gebruik van schoolverlaters: zo komt bij de informaticaberoepen eenderde van de instroom van school. 


\section{Verwachte ontwikkelingen op de korte termijn}

\subsection{Inleiding}

In hoofdstuk 2 is een methodiek gepresenteerd om op basis van informatie over de samenhang tussen persoonlijke kenmerken en mobiliteit op de arbeidsmarkt tot arbeidsmarktprognoses te komen. Nadat in hoofdstuk 3 deze samenhang tussen mobiliteit en kenmerken getoond is, zal in dit hoofdstuk een overzicht gegeven worden van de daarop gebaseerde prognoses. De indeling van dit hoofdstuk loopt parallel aan de in hoofdstuk 2 onderscheiden componenten: paragraaf 4.2 gaat in op de uitbreidingsvraag en paragraaf 4.3 op de bruto vervangingsvraag. Vervolgens komen in paragraaf $4.4,4.5$ en 4.6 achtereenvolgens het aanbod van baanwisselaars, schoolverlaters en herintreders aan bod. In paragraaf 4.7 wordt de confrontatie van vraag en aanbod getoond. Tot slot bevat paragraaf 4.8 de samenvatting en conclusies.

Alle prognoses in dit hoofdstuk worden getoond op het niveau van opleidingssector en beroepssector. Hoewel in een aantal gevallen een verdere opsplitsing van de diverse groepen mogelijk is, worden deze resultaten niet in het rapport getoond. Dit komt de overzichtelijkheid van de tabellen ten goede, en doet niet wezenlijk af aan de geboden informatie. Voor zover de prognoses voor het lage aggregatieniveau gemaakt konden worden, worden ze gepresenteerd in de Statistische Bijlage die bij dit rapport hoort. Het jaar waarop de prognoses betrekking hebben is 2001 .

\subsection{Uitbreidingsvraag}

Net zoals dit in het kader van de arbeidsmarktprognoses voor de middellange termijn is gebeurd, dient ook hier eerst de uitbreidingsvraag voor het prognosejaar bepaald te worden. Deze uitbreidingsvraag is - vanwege de nadruk op de korte termijn gebaseerd op het Centraal Economisch Plan 2000 van het Centraal Planbureau (2000). De uitbreidingsvraag geeft aan welke groei van de werkgelegenheid er het komende jaar te verwachten valt. Deze groei zal leiden tot een vraag naar nieuwe werknemers. Binnen de prognosemethodiek wordt de uitbreidingsvraag dan ook gezien als de 'door de werkgevers gewenste toename' van de werkgelegenheid ${ }^{8}$. In tabel 4.1 staat aangegeven wat voor 2001 de verwachte groei van de werkgelegenheid in de verschillende bedrijfssectoren is. De totale werkgelegenheidsgroei zal ongeveer $1,7 \%$ bedragen. Dit is veel lager dan de verwachte economische groei, die rond de $4 \%$ ligt. Dit verschil wordt veroorzaakt door een flinke stijging in de arbeidsproductiviteit van de werkenden. De groei is niet gelijk verdeeld over alle

8. Deze interpretatie is in principe niet geheel juist, omdat de groei van de werkgelegenheid die door het CPB gepresenteerd wordt afgeleid is van een economisch evenwichtsmodel. Hierin is een aantal aanpassingsprocessen die kunnen optreden bij een personeelstekort - zoals productiviteitsverhoging, of afzien van productiegroei - al verrekend. De feitelijk gewenste uitbreidingsvraag zou dus wel eens hoger kunnen liggen dan de CPB-cijfers suggereren. 
bedrijfssectoren, hoewel de meeste sectoren wel een groei te zien geven. Slechts twee bedrijfssectoren zullen te maken krijgen met een krimpende werkgelegenheid: de sectoren landbouw en visserij en energie tonen een negatieve uitbreidingsvraag, waarbij opgemerkt moet worden dat de krimp in de sector energie zeer beperkt is. Sommige bedrijfssectoren, zoals overheid en onderwijs, groeien slechts heel weinig maar andere, zoals horeca en zakelijke dienstvertening, tonen een groei die ruim boven de totale groei ligt. Deze groei is uiteraard niet de enige bepalende factor van de vraag naar arbeidskrachten. Het is dus niet juist om op basis van deze tabel te stellen dat het onderwijs weinig nieuwe mensen nodig zal hebben. De totale vraag naar arbeidskrachten hangt immers ook af van de bruto vervangingsvraag: de hoeveelheid mensen die het komende jaar uit de desbetreffende bedrijfssector vertrekken en vervangen moeten worden. Zo is het mogelijk dat als de uitstroom van werkenden uit de sector landbouw erg groot is, zelfs deze sector te maken zal krijgen met een tekort aan arbeidskrachten.

Tabel 4.1

Groei van de werkgelegenheid per bedrijfssector, 2001

\begin{tabular}{lr}
\hline Bedriffssector & $\begin{array}{r}\text { Groei } \\
\%\end{array}$ \\
\hline & $-1,1$ \\
Landbouw en visserij & 0,5 \\
Voeding & 1,1 \\
Chemie & 1,2 \\
Metaal en elektrotechniek & 0,7 \\
Overige industrie & $-0,1$ \\
Energie & 0,7 \\
Bouw en onroerend goed & 2,9 \\
Handel en reparatie & 2,7 \\
Transport en communicatie & 1,7 \\
Bank- en verzekeringswezen & 3,3 \\
Horeca en zakelijke dienstverlening & 2,8 \\
Kwartaire diensten & 0,4 \\
Overheid en onderwijs & 1,7 \\
Totaal & \\
\hline
\end{tabular}

Bron: CPB/ROA

De in tabel 4.1 weergegeven groei van de werkgelegenheid per sector kan vertaald worden in een groei van het aantal werkenden per beroep en per opleiding. Zoals dit in paragraaf 3.3 is aangegeven gebeurt dit met behulp van de voor de prognoses voor de middellange termijn ontwikkelde methodiek. Bij deze methodiek wordt de groei van de werkgelegenheid per sector vertaald naar werkgelegenheid per beroep en opleiding. Uitgangspunt hierbij is de bestaande verdeling van beroepen en opleidingen binnen de sectoren. Er wordt daarnaast echter ook gecorrigeerd voor het feit dat er een verschuiving kan optreden in de vraag naar verschillende beroepen en opleidingen binnen de diverse bedrijfssectoren. 
In tabel 4.2 wordt het aantal werkenden in 1998 per beroepssector getoond. Het betreft hier gemiddelden over 1997 en $1998^{\circ}$. Het is in deze tabel te zien dat de werkgelegenheid ongelijk is verdeeld over de verschillende beroepssectoren: ongeveer de helft van de werkende beroepsbevolking is werkzaam in de technische en industrieberoepen en de economisch-administratieve beroepen. De kleinste sectoren worden gevormd door de openbare orde- en veiligheidsberoepen en de culturele beroepen waarin samen nog geen $4 \%$ van de totale beroepsbevolking werkzaam is. Deze bevinding verklaart ook voor een deel de bevindingen uit het vorige hoofdstuk waarin de verdeling van de instroom over de beroepssectoren gepresenteerd werd: de grootste sectoren nemen de meeste schoolverlaters op terwijl de kleinste de minste opnemen. Het moet opgemerkt worden dat deze ongelijke grootte van de beroepssectoren ook gevolgen heeft voor de onzekerheidsmarges van de prognoses: de prognoses zijn gebaseerd op geschatte verbanden, en deze schattingen zijn betrouwbaarder naarmate er meer waarnemingen zijn, dus naarmate de sectoren groter zijn. De betrouwbaarheid van de prognoses voor de economisch-administratieve beroepen zal dus groter zijn dan de betrouwbaarheid voor bijvoorbeeld de openbare orde- en veiligheidsberoepen. Omdat op het moment dat dit rapport gemaakt werd de EBB-cijfers over het jaar 1999 nog niet beschikbaar waren, zijn de aantallen uit tabel 4.2 als basis gebruikt voor de prognoses die in dit en het volgende hoofdstuk getoond worden. Om prognoses te maken voor het jaar 2001, was het dus noodzakelijk ook prognoses te maken voor de jaren 1999 en 2000.

In tabel 4.2 is ook de verwachte (procentuele) uitbreidingsvraag per beroepssector getoond ${ }^{10}$. De totale groei is uiteraard gelijk aan de groei zoals die in tabel 4.1 gegeven is. Ook hier is weer te zien dat de groei zich niet op alle plaatsen gelijk voordoet. Er is bij de verdeling van de groei een duidelijk, alhoewel niet één op één, verband met de cijfers in tabel 4.1. Daar waar er twee bedrijfssectoren te maken krijgen met een kleine krimp van de werkgelegenheid, kent er maar één beroepssector een krimpende werkgelegenheid. Dat zijn de agrarische beroepen, die in 2001 met een half procent zullen krimpen. Die krimp van $0,5 \%$ is overigens minder dan de krimp in de bedrijfssector landbouw en visserij: een gedeelte van deze krimp doet zich dus voor bij 'niet-agrarische beroepen' binnen deze bedrijfssector. De grootste groeiers zijn de informaticaberoepen en de sociaal-culturele beroepen. Deze twee sectoren zullen het komende jaar groeien met ongeveer $4 \%$. Vooral de groei van de informaticaberoepen laat zien dat de groei van de ICT-sector nog steeds niet aan zijn eind is, en dat deze beroepen nog steeds met een 'inhaalslag' bezig zijn ten opzichte van de overige beroepen. Wat bij een vergelijking van tabel 4.1 en 4.2 opvalt is het verschil in groeicijfers tussen de technische bedrijfssectoren chemie en metaal en elektrotechniek, en de groei van de beroepssectoren die 'bij deze bedrijfssectoren

9. De hier getoonde cijfers zijn hoger dan die in De arbeidsmarkt naar opleiding en beroep tot 2004 en de daarbij behorende Statistische Bijlage (ROA, 1999a en 1999b) gepresenteerd worden, omdat in dit rapport de scholieren met een substantiële bijbaan meegeteld zijn met de werkenden.

10. De percentages zijn daarbij niet bepaald op basis van het aantal werkenden in 1997/1998, maar op basis van het (verwachte) aantal werkenden in 2000. 
horen'. Voor de beide bedrijfssectoren wordt er voor het komende jaar een werkgelegenheidsgroei van ca. $1 \%$ verwacht, voor de technische en industrieberoepen daarentegen wordt er een groei van slechts $0,2 \%$ verwacht. De manier waarop dit verklaard moet worden is dat de beide bedrijfssectoren in hoge mate hun vraag naar personeel verleggen naar andere beroepssectoren, zoals bijvoorbeeld de informaticaberoepen. Overigens wil de beperkte groei van deze beroepssector helemaal niet zeggen dat er geen personeelstekorten op zullen treden. Afhankelijk van de vervangingsvraag kan de totale vraag voor deze beroepen veel hoger liggen dan de uitbreidingsvraag.

Omdat de beroepssectoren vrij sterk verschillen wat betreft hun omvang, is het niet zo dat de sector met de hoogste procentuele uitbreidingsvraag ook de meeste nieuwe arbeidskrachten nodig heeft. De grootste groei in de werkgelegenheid gemeten in aantal werkenden - zal plaatsvinden in de economisch-administratieve beroepen: de werkgelegenheid in deze sector zal met 55.000 mensen toenemen. Ook de verzorgende en dienstverlenende beroepen zal een grote toename van de werkgelegenheid laten zien met 23.500 mensen. De groei van de werkgelegenheid in de andere sectoren zal aanzienlijk kleiner zijn, zo groeit de werkgelegenheid in de sectoren met de hoogste procentuele groei (de informaticaberoepen en de sociaalculturele beroepen) met in totaal slechts 16.500 mensen.

Tabel 4.2

Werkgelegenheid in 1997/1998 en uitbreidingvraag voor 2001 per beroepssector

\begin{tabular}{|c|c|c|c|}
\hline Beroepssector & $\begin{array}{r}\text { Werkgelegenheid } \\
\text { gem. 1997/1998 }\end{array}$ & $\begin{array}{c}\text { Uitbrei } \\
\quad \%\end{array}$ & $\begin{array}{l}\text { dingsvraag } \\
\text { Typering }\end{array}$ \\
\hline Pedagogische beroepen & 344.500 & 0,6 & laag \\
\hline Culturele beroepen & 129.500 & 1,9 & gemiddeld \\
\hline Agrarische beroepen & 268.000 & $-0,5$ & erg laag \\
\hline Technische en industrieberoepen & 1.478 .000 & 0,2 & laag \\
\hline Transportberoepen & 373.000 & 2,4 & hoog \\
\hline Medische en paramedische beroepen & 378.500 & 1,8 & gemiddeld \\
\hline Economisch-administratieve beroepen & 1.866 .000 & 2,6 & hoog \\
\hline Informaticaberoepen & 194.500 & 3,7 & erg hoog \\
\hline Sociaal-culturele beroepen & 199.000 & 4,0 & erg hoog \\
\hline Verzorgende en dienstverlenende beroepen & 1.032 .000 & 2,3 & gemiddeld \\
\hline Openbare orde- en veiligheidsberoepen & 106.000 & 0,7 & gemiddeld \\
\hline Totaal & 6.504 .500 & 1,7 & - \\
\hline
\end{tabular}

Bron: CBS/ROA

In tabel 4.3 wordt de werkgelegenheid in 1998 en de verwachte uitbreidingsvraag voor 2001 gepresenteerd naar opleidingssector. Het is te zien dat de meeste werkenden een opleiding op VMBO- of MBO-niveau hebben. Het MBO is het belangrijkste opleidingsniveau op dit moment op de arbeidsmarkt: ruim $40 \%$ van de beroepsbevolking heeft een opleidingsachtergrond op dit niveau. Het aantal werkenden dat een WO-achtergrond heeft is relatief klein, slechts $8 \%$ van de totale beroeps- 
bevolking. Op basis van het aantal werkenden is ook te zien waarom er - zoals hoofdstuk 3 liet zien - nog vrij veel mogelijkheden zijn voor mensen met een lage opleiding: bijna $30 \%$ van de werkenden heeft een opleidingsniveau onder het niveau van een startkwalificatie. Hoewel deze opleidingen voor de nieuwe instroom aan belang inboeten, is de 'aanwezige voorraad' op de arbeidsmarkt nog lang niet verdwenen. Ook naar opleiding gerangschikt blijken de techniek en de economie de grootste sectoren: de twee grootste opleidingssectoren zijn MBO landbouw en techniek en MBO economie.

Het is voor de uitbreidingsvraag nu veel lastiger om de verbinding met tabel 4.1 te leggen, omdat er maar weinig opleidingssectoren een duidelijke binding hebben met slechts één bedrijfssector of beroepssector. Werd het uit de vorige tabellen al duidelijk dat de vraag niet gelijk verdeeld is over bedrijfssectoren of beroepssectoren, tabel 4.3 maakt duidelijk dat de vraag ook niet gelijk verdeeld is over opleidingssectoren. Dat de vraag ongelijk verdeeld is over de opleidingsrichtingen valt natuurlijk op basis van de voorgaande tabellen te verwachten: de opleidingen die op de landbouw gericht zijn zullen een lagere vraag kennen dan die gericht zijn op bijvoorbeeld de informatica ${ }^{11}$. Veel opvallender echter dan het verschil tussen de richtingen is het verschil tussen de niveaus: het valt in de tabel op dat er een duidelijk patroon zichtbaar is: vanaf het MBO-niveau is er sprake van een bovengemiddelde vraag, terwijl daaronder juist een lager dan gemiddelde vraag wordt verwacht. Het proces van upgrading speelt niet alleen op de middellange termijn een rol maar de effecten hiervan zijn ook op korte termijn goed zichtbaar. Door deze upgrading zal het aantal werkenden met een lage opleiding langzaam afnemen. In het huidige tempo zal het echter nog heel lang duren voordat deze groep geen rol van betekenis meer speelt op de arbeidsmarkt. Bij een werkgelegenheidskrimp van $4 \%$ per jaar zal over tien jaar het aantal werkenden met uitsluitend Basisonderwijs nog steeds zo'n 300.000 bedragen. Waarschijnlijk zal de krimp de komende jaren steeds groter worden, maar het is zeker niet zo dat er voor laag opgeleiden op korte termijn geen plaats meer zal zijn op de arbeidsmarkt.

Op basis van de in tabel 4.3 getoonde ontwikkelingen van het aantal werkenden met een lage opleiding is het wel duidelijk dat de in hoofdstuk 3 geconstateerde mogelijkheden voor deze lager opgeleiden uitsluitend het gevolg zijn van vervangingsvraag. Juist omdat het aantal werkenden met deze opleidingsachtergrond nog groot is, bestaat hier een relatief grote vervangingsvraag die groter is dan de negatieve uitbreidingsvraag. Met andere woorden, er verlaten meer laaggeschoolden de arbeidsmarkt dan nodig is om de gewenste reductie te bewerkstelligen. Per saldo bestaat er dus nog steeds een positieve vraag naar laag opgeleiden. Dit saldo wordt beïnvloed door de snelheid waarmee de werkgelegenheid van lager opgeleiden terugloopt, en de ontwikkelingen van de vervangingsvraag. Zoals hierboven al is aangegeven is er de komende jaren sprake van een negatieve uitbreidingsvraag,

11. Dit is overigens in tabel 4.3 niet terug te zien, omdat zowel de op de landbouw als op de informatica gerichte opleidingen zijn samengenomen in de opleidingssector landbouw en techniek. Dit maakt overigens duidelijk dat er binnen de diverse opleidingssectoren nog grote verschillen mogelijk zijn! 
maar blijt er een aanzienlijke - hoewel krimpende - werkgelegenheid voor lager opgeleiden bestaan. De vervangingsvraag wordt door twee tegengestelde ontwikkelingen beïnvloed. Tabel 4.3 suggereert dat de vervangingsvraag steeds kleiner zal worden omdat het gewenste aantal werkenden met een lage opleiding de komende jaren afneemt. Aan de andere kant is er de laatste jaren een stijging van het gemiddelde opleidingsniveau van schoolverlaters te zien geweest. Hierdoor zal de lager opgeleide beroepsbevolking de komende jaren te maken krijgen met een relatief vergrijzing. Als gevolg daarvan zal de vervangingsvraag de komende jaren juist stijgen. Welke van de twee effecten het grootste effect zal hebben op de vervangingsvraag is niet op voorhand duidelijk. Hierdoor is het ook heel moeilijk in te schatten wanneer de totale vraag naar laag opgeleiden negatief geworden zal zijn en er voor hen echt geen plaats meer is op de arbeidsmarkt.

Tabel 4.3

Werkgelegenheid in 1997/1998 en uitbreidingvraag voor 2001 per opleidingssector

\begin{tabular}{lrrl}
\hline Opleidingssector & $\begin{array}{r}\text { Werkgelegenheid } \\
\text { gem. }\end{array}$ & $\begin{array}{c}\text { Uitbreidingsvraag } \\
\%\end{array}$ & Typering \\
\hline Basisonderwijs & 480.000 & $-3,5$ & erg laag \\
VMBO theorie & 456.500 & 1,0 & laag \\
VMBO landbouw en techniek & 496.500 & $-1,5$ & laag \\
VMBO economie & 156.500 & $-2,4$ & laag \\
VMBO verzorging & 182.500 & 0,2 & laag \\
HAVONWO & 342.000 & 3,9 & hoog \\
MBO landbouw en techniek & 1.034 .000 & 2,2 & gemiddeld \\
MBO economie & 767.000 & 2,3 & gemiddeld \\
MBO dienstverlening en gezondheidszorg & 685.500 & 2,3 & gemiddeld \\
HBO landbouw en techniek & 268.000 & 2,0 & gemiddeld \\
HBO economie & 265.500 & 3,4 & hoog \\
HBO onderwijs en sociaal-cultureel & 517.000 & 1,9 & gemiddeld \\
HBO paramedisch & 108.000 & 4,3 & erg hoog \\
WO landbouw en techniek & 133.500 & 2,8 & hoog \\
WO economie & 160.500 & 4,3 & erg hoog \\
WO letteren en sociaal-cultureel & 159.000 & 3,7 & hoog \\
WO medisch & 62.500 & 1,6 & gemiddeld \\
& & & \\
Totaal & 6.504 .500 & 1,7 & \\
& & & \\
\hline
\end{tabular}

Bron: ROA

Naast de hoge vervangingsvraag suggereert tabel 4.3 nog een verklaring voor de relatief hoge arbeidsmarktinstroom van laagopgeleiden. $\mathrm{Er}$ is een hoge (uitbreidings) vraag naar hoger opgeleiden maar er is al enige tijd sprake van een krappe arbeidsmarkt. Het zou kunnen zijn dat een deel van de geobserveerde vraag naar lager opgeleiden in feite 'substitutievraag' is, waarbij werkgevers de vacatures - al dan niet met behulp van een cascadeconstructie - vervullen met lager opgeleiden dan dat zij eigenlijk hadden willen hebben. Wanneer dat het geval is, zal de vraag naar lager opgeleiden ook afnemen wanneer het aanbod van hoger opgeleiden (met name op 
het HBO-niveau) zal toenemen. In beide gevallen impliceert tabel 4.3 'slecht nieuws' voor de lager opgeleiden. Omdat, zoals in hoofdstuk 3 getoond is, het merendeel van de herintreders vanuit non-participatie gekenmerkt wordt door een relatief lage opleidingsgraad, impliceert de verwachte krimp in de werkgelegenheid voor de lagere opleidingssectoren dat het steeds moeilijker zal worden herintreders te plaatsen. Het vergroten van de participatie van de groep niet-participerenden - hetzij ouderen, hetzij vrouwen - zal door deze werkgelegenheidsafname voor de lagere opleidingsniveaus dus bemoeilijkt worden. Overigens kan het natuurlijk niet uitgesloten worden dat door de stijging van het algemene opleidingsniveau ook het opleidingsniveau van de niet-participerenden de komende jaren zal stijgen.

\subsection{Bruto vervangingsvraag}

Een tweede component van de vraag naar arbeidskrachten wordt gevormd door de (bruto) vervangingsvraag. Deze vervangingsvraag is de totale uitstroom uit de groep werkenden die vervangen moet worden om de omvang van het aantal werkenden constant te houden ${ }^{12}$. Omdat in dit rapport gebruik gemaakt wordt van de bruto vervangingsvraag die gelijk is aan de totale uitstroom, kunnen de cijfers niet vergeleken worden met de vervangingsvraagcijfers uit De arbeidsmarkt naar opleiding en beroep. In dat rapport wordt namelijk uitgegaan van de netto vervangingsvraag: de uitstroom van werkenden, na correctie voor herintreders en baanwisselaars. Om misverstanden te voorkomen wordt in dit rapport daarom ook geregeld gebruik gemaakt van de aanduiding 'uitstroom'. De verwachte uitstroom is gerelateerd aan een aantal kenmerken van de werkenden. In hoofdstuk 3 is reeds ingegaan op deze onderliggende verklarende factoren voor het optreden van mobiliteit op de arbeidsmarkt. Er is daar geïllustreerd dat leeftijd en geslacht zeer bepalende factoren zijn voor de optredende mobiliteit. Als achtergrondinformatie bij de verwachte vervangingsvraag wordt daarom in tabel 4.4 en 4.5 informatie gegeven over de leeftijdsopbouw van de werkenden in de diverse beroepssectoren, en het percentage vrouwen dat daarin werkzaam is.

In tabel 4.4 is te zien dat een aantal beroepssectoren te maken heeft met een relatief oud werknemersbestand. Is in de totale beroepsbevolking slecht $17 \%$ ouder dan 50 , in de pedagogische beroepen en de agrarische beroepen is dit meer dan een kwart: $26 \%$ is daar ouder dan 50 . De oorzaak van deze vergrijzing moet gezocht worden in het feit dat in deze twee sectoren de afgelopen jaren een lage groei van de werkgelegenheid heeft plaatsgehad (zie ROA, 1999a). Dit heeft blijkbaar een vermindering van de instroom van een nieuw - en jonger - personeel tot gevolg gehad. De hieruit resulterende vergrijzing van het personeelsbestand in deze beroepssectoren betekent dat ze de komende jaren te maken zullen krijgen met een relatief hoge personeelsuitstroom als gevolg van deze vergrijzing.

12. Merk op dat de krimp van de werkgelegenheid verrekend wordt met de uitbreidingsvraag. Voor het bepalen van de bruto vervangingsvraag moet er dus van uit worden gegaan dat de totale werkgelegenheid constant is. 
Naast de leeftijdsopbouw is ook het geslacht van de werkenden van belang voor de verwachte mobiliteit. In tabel 4.5 wordt het percentage vrouwen per beroepssector weergegeven. Zoals in hoofdstuk 3 getoond is, hebben vrouwen een ander mobiliteitspatroon dan mannen. Voor veel vrouwen is het krijgen en verzorgen van kinderen nog steeds een reden om (al dan niet tijdelijk) te stoppen met werken: zij stromen daarom relatief gezien veel vaker uit dan mannen. Deze arbeidsmarktuittrede van vrouwen wordt ook wel aangeduid met de term 'kinderdal'. Als gevolg hiervan zullen sectoren waar veel vrouwen werkzaam zijn in principe te maken hebben met een veel groter personeelsverloop, en dus ook met een veel grotere bruto vervangingsvraag. Vrouwen zijn nog steeds ondervertegenwoordigd zijn op de arbeidsmarkt: in tabel $\mathbf{4 . 5}$ is te zien dat slechts $39 \%$ van de werkenden vrouw is. Daarnaast valt het op dat er vrijwel geen enkele beroepssector is waar evenveel mannen als vrouwen werkzaam zijn. In vrijwel alle sectoren zijn óf de vrouwen sterk oververtegenwoordigd zoals bij de medische en paramedische beroepen en de verzorgende en dienstverlenende beroepen, of het zijn juist de mannen die zeer sterk oververtegenwoordigd zijn, zoals in de technische en industrieberoepen, de transportberoepen en de informaticaberoepen. Dit verschil in de man-vrouw verdeling tussen de sectoren draagt ook sterk bij aan de verschillen in vervangingsvraag tussen de sectoren.

Tabel 4.4

Percentage ouderen per beroepssector

\begin{tabular}{|c|c|c|c|}
\hline Beroepssector & $\begin{array}{c}\text { Jonger dan } 35 \\
\%\end{array}$ & $\begin{array}{l}\text { Ouder dan } 35 \\
\text { jonger dan } 50 \\
\%\end{array}$ & $\begin{array}{c}\text { Ouder dan } 50 \\
\%\end{array}$ \\
\hline Pedagogische beroepen & 22 & 52 & 26 \\
\hline Culturele beroepen & 31 & 51 & 18 \\
\hline Agrarische beroepen & 37 & 37 & 26 \\
\hline Technische en industrieberoepen & 43 & 40 & 18 \\
\hline Transportberoepen & 44 & 40 & 17 \\
\hline Medische en paramedische beroepen & 42 & 44 & 13 \\
\hline Economisch-administratieve beroepen & 41 & 42 & 18 \\
\hline Informaticaberoepen & 49 & 42 & 9 \\
\hline Sociaal-culturele beroepen & 38 & 47 & 16 \\
\hline Verzorgende en dienstverlenende beroepen & 49 & 37 & 15 \\
\hline Openbare orde- en veiligheidsberoepen & 46 & 43 & 11 \\
\hline Totaal & 42 & 41 & 17 \\
\hline
\end{tabular}

Bron: CBS/ROA

Op basis van de in het stromenmodel geschatte gedragsrelaties en de informatie zoals hierboven gepresenteerd, kan per beroepssector en per opleidingssector een verwachte uitstroom berekend worden. Deze uitstroom geeft de omvang van de bruto vervangingsvraag aan. In tabel 4.6 wordt de verwachte vervangingsvraag voor het jaar 2001 gepresenteerd per beroepssector. De gemiddelde verwachte vervangingsvraag is hoog: in totaal verlaat ruim $13 \%$ van de werkenden zijn of haar baan. Dit percentage is veel hoger dan de voor de middellange termijn gepresenteerde 56 
jaarlijkse cijfers voor de netto vervangingsvraag. Ook uit dat verschil blijkt dat baanmobiliteit en herintreding zeer belangrijke fenomenen zijn op de arbeidsmarkt. Het valt op dat het percentage ouderen of vrouwen per beroepssector op zichzelf niet alles verklaart: in tegenstelling tot wat op basis van alleen het percentage vrouwen of de leeftijd verwacht mocht worden, blijken de medische en paramedische beroepen een erg lage verwachte vervangingsvraag te hebben. Dit geldt ook voor de pedagogische beroepen: op basis van de leeftijdsopbouw kan ook hier een hoge uitstroom verwacht worden, maar toch laat de tabel zien dat deze het komende jaar nog niet op zal treden. Er spelen dus behalve de genoemde factoren ook sectorspecifieke effecten mee. Daarnaast zijn ook de interacties tussen opleiding, leeftijd en geslacht van belang. Zo wordt de lage bruto vervangingsvraag in de pedagogische beroepen mede veroorzaakt door het feit dat gegeven de leeftijd en de overige kenmerken de uitstroom lager ligt dan in de overige sectoren. De lage bruto uitstroom in de medische en paramedische beroepen wordt voor een groot deel bepaald door de relatief lage mobiliteit van mensen met een opleiding in de opleidingssector HBO-paramedisch of WO-medisch.

Tabel 4.5

Percentage mannen en vrouwen per beroepssector

\begin{tabular}{lcc}
\hline Beroepssector & $\begin{array}{c}\text { Mannen } \\
\%\end{array}$ & $\begin{array}{c}\text { Vrouwen } \\
\%\end{array}$ \\
& & 53 \\
Pedagogische beroepen & 47 & 45 \\
Culturele beroepen & 55 & 22 \\
Agrarische beroepen & 78 & 9 \\
Technische en industrieberoepen & 91 & 11 \\
Transportberoepen & 89 & 71 \\
Medische en paramedische beroepen & 29 & 46 \\
Economisch-administratieve beroepen & 54 & 11 \\
Informaticaberoepen & 89 & 61 \\
Sociaal-culturele beroepen & 40 & 71 \\
Verzorgende en dienstverlenende beroepen & 30 & 12 \\
Openbare orde- en veiligheidsberoepen & 88 & 39 \\
Totaal & & 61 \\
\hline
\end{tabular}

Bron: CBS/ROA

Er zijn grote verschillen zichtbaar tussen de sectoren: zo kennen de al genoemde medische en paramedische beroepen een erg lage vervangingsvraag van nog geen $8 \%$, terwijl de verzorgende en dienstverlenende beroepen een erg hoge vervangingsvraag kennen van bijna $21 \%$. Dit verschil wordt mede veroorzaakt door het verschil in opleidingsniveau tussen beide sectoren: bij de verzorgende en dienstvertenende beroepen is het opleidingsniveau veel lager, hetgeen resulteert in een veel hogere uitstroom. Ook de transportberoepen vallen op door een hoge vervangingsvraag. Ook deze hoge vervangingsvraag moet voor een groot deel aan het gemiddelde opleidingsniveau worden toegeschreven. Dit is des te opmerkelijker daar beide sectoren waar deze hoge uitstroom zich voordoet te maken hebben met vrij grote problemen om voldoende personeel te vinden. Misschien dat een (gedeeltelijke) 
oplossing gevonden kan worden in het 'zuiniger' omspringen met het eigen personeel.

Tabel 4.6

Bruto vervangingsvraag (totale uitstroom) per beroepssector, 2001

\begin{tabular}{lrrl}
\hline Beroepssector & Aantal & Percentage & Typering \\
\hline Pedagogische beroepen & & & \\
Culturele beroepen & 32.500 & 9,4 & laag \\
Agrarische beroepen & 15.500 & 12,7 & hoog \\
Technische en industrieberoepen & 33.500 & 13,7 & hoog \\
Transportberoepen & 188.000 & 12,3 & gemiddeld \\
Medische en paramedische beroepen & 60.500 & 15,7 & erg hoog \\
Economisch-administratieve beroepen & 30.500 & 7,9 & erg laag \\
Informaticaberoepen & 249.000 & 12,1 & gemiddeld \\
Sociaal-culturele beroepen & 26.500 & 11,5 & gemiddeld \\
Verzorgende en dienstverlenende beroepen & 25.000 & 12,5 & gemiddeld \\
Openbare orde- en veiligheidsberoepen & 213.500 & 20,9 & erg hoog \\
& 9.500 & 10,0 & laag \\
Totaal & & & \\
& 905.000 & 13,4 & - \\
\hline
\end{tabular}

Bron: ROA

De verwachte vervangingsvraag kan ook per opleidingssector gepresenteerd worden. In tabel 4.7 worden deze gegevens getoond. Daar waar bij de uitbreidingsvraag de relatie tussen de uitbreidingsvraag per beroep en de uitbreidingsvraag per opleidingssector niet duidelijk was vanwege de optredende upgrading en vraagverschuiving naar andere opleidingen, is de relatie tussen de vervangingsvraag per beroep en de vervangingsvraag per opleiding veel duidelijker. Deze relatie is namelijk geheel gebaseerd op de bestaande verdelingen van opleidingen binnen beroepen, en wordt niet beïnvloed door upgrading of andere verschuivingen in de opleidingsstructuur van de werkgelegenheid. De cijfers in tabel 4.7 komen dan ook duidelijk overeen met de cijfers in tabel 4.6. Het totale uitstroompercentage is uiteraard weer $13,4 \%$. In tegenstelling tot de tabel met de cijfers over de verwachte uitbreidingsvraag, is er in deze tabel geen duidelijk patroon te ontdekken. Er lijkt een lichte tendens te bestaan dat de lagere opleidingsniveaus een relatief hoge uitstroom kennen, de middelbare niveaus een lage uitstroom, en de hogere niveaus weer een hogere uitstroom. Dit patroon wordt echter vertekend door het feit dat er op alle niveaus relatief algemene en relatief specialistische opleidingssectoren zijn. De algemene opleidingssectoren kennen een hogere uitstroom dan hun niveaugemiddelde, terwijl de meer specialistische opleidingssectoren juist een lagere uitstroom kennen dan hun niveaugemiddelde. Zo kennen de opleidingssectoren VMBO theorie, HAVONWO en MBO dienstverlening en gezondheidszorg een hogere uitstroom dan het gemiddelde en de sectoren landbouw en techniek (op alle niveaus) en HBO paramedisch en WO medisch een lagere uitstroom.

Bij alle uitstroomcijfers moet bedacht worden dat een groot deel van deze uitstroom de arbeidsmarkt niet verlaat, maar slechts werkzaam wordt in een andere baan. Deze groep komt dus ogenblikkelijk terug als 'doorstroom'. Daarnaast verlaat een deel van de uitstroom slechts tijdelijk de arbeidsmarkt, om op een later tijdstip weer 58 
terug te komen. Voor deze groep is het echter de vraag of de opleiding en de ervaring die ze nu hebben voldoende is om hen op termijn weer zicht te geven op een baan die vergelijkbaar is met de baan die ze nu verlaten.

Tabel 4.7

Bruto vervangingsvraag (totale uitstroom) per opleidingssector, 2001

\begin{tabular}{lrrl}
\hline & Aantal & Percentage & Typering \\
Opleidingssector & & & \\
\hline & 74.500 & 17,2 & hoog \\
Basisonderwijs & 90.000 & 20,5 & erg hoog \\
VMBO theorie & 65.000 & 13,4 & gemiddeld \\
VMBO landbouw en techniek & 23.500 & 16,1 & hoog \\
VMBO economie & 36.500 & 19,9 & erg hoog \\
VMBO verzorging & 64.500 & 18,8 & hoog \\
HAVONWO & 120.000 & 10,6 & laag \\
MBO landbouw en techniek & 107.000 & 12,7 & gemiddeld \\
MBO economie & 108.000 & 14,7 & hoog \\
MBO dienstverlening en gezondheidszorg & 28.000 & 9,8 & laag \\
HBO landbouw en techniek & 30.000 & 10,0 & laag \\
HBO economie & 59.000 & 11,1 & gemiddeld \\
HBO onderwijs en sociaal-cultureel & 11.000 & 8,8 & laag \\
HBO paramedisch & 13.500 & 10,8 & gemiddeld \\
WO landbouw en techniek & 19.500 & 11,1 & gemiddeld \\
WO economie & 19.500 & 11,8 & gemiddeld \\
WO letteren en sociaal-cultureel & 5.500 & 8,4 & erg laag \\
WO medisch & & & \\
Totaal & 905.000 & 13,4 & - \\
& & & \\
\hline
\end{tabular}

Bron: ROA

\subsection{Instroom van baanwisselaars}

Van de verwachte totale uitstroom zoals die in de vorige paragraaf getoond is, is een groot deel geen netto uitstroom, maar baanmobiliteit. Met andere woorden: een deel van die mensen verlaat niet de arbeidsmarkt, maar verandert - al dan niet gedwongen - van baan. Op die manier vormen deze mensen een uitstroomcategorie, maar tegelijkertijd ook een aanbodcategorie van nieuwe arbeidskrachten. In hoofdstuk 3 is al een overzicht gegeven van de patronen die daarbij optreden. In deze paragraaf wordt aangegeven hoe groot het aanbod van baanwisselaars per beroepssector en opleidingssector zal zijn in 2001. Er wordt hierbij niet verder ingegaan op de vraag of deze baanwisselaars hun oude baan opgezegd hebben omdat ze een nieuwe, betere baan konden vinden, of dat ze hun nieuwe baan gezocht hebben omdat ze gedwongen werden hun oude baan om wat voor reden dan ook te verlaten. Zoals in hoofdstuk 3 al werd aangegeven ontbreken daarover de gegevens.

Het aanbod uit baanmobiliteit per beroepssector staat gepresenteerd in tabel 4.8. Dit is dus niet het aantal werkenden dat per beroepssector zijn baan verlaat en mobiel is, maar dit is de instroom van mensen die elders al werkzaam waren in een andere baan. Als de tabel vergeleken wordt met de bruto uitstroom uit de vorige paragraaf, dan is te zien dat inderdaad een groot deel van de uitstroom de arbeidsmarkt niet 
verlaat: $13,4 \%$ van de werkenden stroomt uit, maar $6,5 \%$ van de werkenden is baanmobiel. De netto uitstroom is dus $6,9 \%$ van het aantal werkenden. Dit percentage is aanzienlijk lager dan de bruto uitstroom maar nog steeds erg hoog. In de tabel is te zien dat de twee sectoren met de hoogste uitstroom ook de hoogste instroom uit baanmobiliteit kennen: zowel de transportberoepen als de verzorgende en dienstverlenende beroepen kennen een hoge instroom uit baanmobiliteit. Beide kennen een instroom van rond de $8 \%$ van het aantal werkenden. Aan de andere kant staan de openbare orde- en veiligheidsberoepen die een instroom uit baanmobiliteit kennen van slechts $1,7 \%$.

Tabel 4.8

Aanbod van baanwisselaars per beroepssector, 2001

\begin{tabular}{|c|c|c|c|}
\hline Beroepssector & Aantal & Percentage & Typering \\
\hline $\begin{array}{l}\text { Pedagogische beroepen } \\
\text { Culturele beroepen } \\
\text { Agrarische beroepen } \\
\text { Technische en industrieberoepen } \\
\text { Transportberoepen } \\
\text { Medische en paramedische beroepen } \\
\text { Economisch-administratieve beroepen } \\
\text { Informaticaberoepen } \\
\text { Sociaal-culturele beroepen } \\
\text { Verzorgende en dienstverlenende beroepen } \\
\text { Openbare orde- en veiligheidsberoepen }\end{array}$ & $\begin{array}{r}17.000 \\
9.000 \\
13.500 \\
85.000 \\
32.500 \\
20.000 \\
133.000 \\
17.000 \\
13.000 \\
78.000 \\
1.500\end{array}$ & $\begin{array}{l}4,8 \\
7,3 \\
5,5 \\
5,6 \\
8,5 \\
5,2 \\
6,4 \\
7,4 \\
6,5 \\
7,6 \\
1,7\end{array}$ & $\begin{array}{l}\text { laag } \\
\text { hoog } \\
\text { gemiddeld } \\
\text { gemiddeld } \\
\text { erg hoog } \\
\text { laag } \\
\text { gemiddeld } \\
\text { hoog } \\
\text { gemiddeld } \\
\text { erg hoog } \\
\text { erg laag }\end{array}$ \\
\hline Totaal & 437.500 & 6,5 & - \\
\hline
\end{tabular}

Bron: ROA

In tabel 4.9 staat de instroom uit de baanmobiliteit naar opleidingssector gepresenteerd. Zoals voor de baanmobiliteit per beroepssector geldt, geldt ook voor de baanmobiliteit per opleidingssector dat de sectoren met de hoogste bruto uitstroom de hoogste percentages baanmobiliteit kennen. De verschillen tussen de opleidingssectoren onderling zijn ongeveer even groot als tussen de beroepssectoren onderling: het verschil tussen de hoogste en laagste percentages in de tabel is ongeveer 3 procentpunt. Uit tabel 4.9 is ook weer de relatief zwakke positie van de lager opgeleiden te herleiden. Bij de prognoses voor de uitstroom bleek dat zowel de lage als de hoge opleidingsniveaus te maken zullen krijgen met een hoge uitstroom. Deze hoge uitstroom vertaalt zich zowel bij de lagere als de hogere opleidingsniveaus in een hoog aantal baanwisselaars. Voor de lager opgeleiden is de netto uitstroom (het verschil tussen de bruto uitstroom en de baanwisselaars) veel groter. Van de lager opgeleiden verlaat dus een relatief groot deel de arbeidsmarkt. Bij het Basisondenwijs is de uitstroom $17,2-8,1=9 \%$ van het aantal werkenden, bij WO economie is dat slechts $11,1-7,7=3,4 \%$.

Merk op dat de baanmobiliteit die in tabel 4.7 vermeld is ook met beroepsmobiliteit gepaard kan gaan. Met andere woorden: het aanbod dat per beroepssector vermeld wordt, hoeft niet noodzakelijkerwijs uit diezelfde sector afkomstig te zijn. Omdat van- 
wege deze beroepsmobiliteit het aanbod van baanwisselaars per beroepssector niet gelijk is aan de uitstroom van baanwisselaars per beroepssector geeft tabel 4.7 dus geen 'mobiliteitskans' van de werkenden per beroepssector. Voor de cijfers in tabel 4.8 ligt dat iets anders. Omdat baanmobiliteit het opleidingsniveau immers niet verandert is het aanbod van baanwisselaars per opleidingsector gelijk aan de uitstroom van baanwisselaars per opleidingssector. De cijfers in deze tabel kunnen dus wel geïnterpreteerd worden als 'mobiliteitskans' per opleidingssector.

Tabel 4.9

Aanbod van baanwisselaars per opleidingssector, 2001

\begin{tabular}{|c|c|c|c|}
\hline Opleidingssector & Aantal & Percentage & Typering \\
\hline $\begin{array}{l}\text { Basisonderwijs } \\
\text { VMBO theorie } \\
\text { VMBO landbouw } \\
\text { VMBO economie } \\
\text { VMBO verzorging } \\
\text { HAVONWO } \\
\text { MBO landbouw } \\
\text { MBO economie } \\
\text { MBO dienstverlening en gezondheidszorg } \\
\text { HBO landbouw } \\
\text { HBO economie } \\
\text { HBO onderwijs en sociaal-cultureel } \\
\text { HBO paramedisch } \\
\text { WO landbouw en techniek } \\
\text { WO economie } \\
\text { WO letteren en sociaal-cultureel } \\
\text { WO medisch }\end{array}$ & $\begin{array}{r}35.000 \\
32.500 \\
27.000 \\
10.500 \\
12.500 \\
30.000 \\
60.500 \\
58.000 \\
51.500 \\
15.000 \\
18.500 \\
29.500 \\
6.000 \\
8.000 \\
13.500 \\
12.500 \\
3.000\end{array}$ & $\begin{array}{l}8,1 \\
7,5 \\
5,6 \\
7,0 \\
6,7 \\
8,7 \\
5,4 \\
6,9 \\
7,0 \\
5,3 \\
6,2 \\
5,5 \\
4,8 \\
6,2 \\
7,7 \\
7,3 \\
4,8\end{array}$ & $\begin{array}{l}\text { erg hoog } \\
\text { hoog } \\
\text { gemiddeld } \\
\text { hoog } \\
\text { gemiddeld } \\
\text { erg hoog } \\
\text { laag } \\
\text { gemiddeld } \\
\text { gemiddeld } \\
\text { laag } \\
\text { gemiddeld } \\
\text { laag } \\
\text { erg laag } \\
\text { gemiddeld } \\
\text { hoog } \\
\text { hoog } \\
\text { laag }\end{array}$ \\
\hline Totaal & 437.500 & 6,5 & - \\
\hline
\end{tabular}

Bron: ROA

\subsection{Instroom van schoolverlaters op de arbeidsmarkt}

Naast het beschikbare aanbod van arbeidskrachten ten gevolge van baanmobiliteit vindt er ook instroom plaats vanuit de groep schoolverlaters en de groep niet-participerenden. Deze paragraaf geeft een overzicht van verwachte instroom van schoolverlaters. De volgende paragraaf gaat in op het aanbod van herintreders.

De prognoses voor het aantal schoolverlaters zijn, zoals eerder is aangegeven, niet gebaseerd op het stromenmodel maar op het instroommodel dat ook voor de arbeidsmarktprognoses voor de middellange termijn wordt gehanteerd. Binnen dit model wordt op basis van de Referentieramingen van het Ministerie van Onderwijs, Cultuur en Wetenschappen een prognose gemaakt van de aantallen schoolverlaters die per jaar de arbeidsmarkt betreden. Hierin worden ook de aantallen schoolverlaters uit het niet-initieel onderwijs meegeteld. Omdat deze voor een zeer groot deel al werkzaam zijn, en hun opleiding naast hun werk afronden, zou dit in het model tot een dubbeltelling leiden. Daarom worden de gegevens over de herkomst van de schoolverlaters uit het niet-initieel onderwijs gebruikt om hiervoor te corrigeren. 
Er wordt ook gecorrigeerd voor het aantal scholieren dat een opleiding afrondt en aansluitend aan een vervolgopleiding begint. Een bekend voorbeeld zijn de afstudeerders van het WWO waarvan een zeer groot deel aansluitend een HBO- of WOopleiding gaat volgen. Het zou onjuist zijn om deze schoolverlaters van het WWO mee te tellen bij het aanbod op de arbeidsmarkt. Het zou in dit verband misschien beter zijn om te spreken van 'onderwijsverlaters' in plaats van 'schoolverlaters'. Op basis van de SIS-data van het ROA wordt nagegaan wat de percentages doorleerders zijn per opleidingsniveau, en deze percentages worden vervolgens toegepast op de verwachte aantallen afstudeerders per opleidingstype. Na deze correcties resulteert uiteindelijk een prognose voor het aantal schoolverlaters dat zich daadwerkelijk aan zal bieden op de arbeidsmarkt. Het bezwaar van deze methodiek is dat in het verleden een deel van de doorleerders gekozen heeft voor een vervolgopleiding omdat er op dat moment voor hen op de arbeidsmarkt geen mogelijkheden waren. Of juist andersom: iemand heeft geen vervolgopleiding gevolgd omdat hij op de arbeidsmarkt een beter alternatief gevonden heeft. Als er een dergelijk verband bestaat tussen de vraag naar schoolverlaters en het doorleergedrag kan het toepassen van waargenomen doorleerpercentages leiden tot onjuiste prognoses als de situatie op de arbeidsmarkt duidelijk anders is dan in het verleden. Omdat het hier prognoses voor de korte termijn betreft, zullen die afwijkingen echter niet zo groot zijn.

Tabel 4.10

Instroom van schoolverlaters per opleidingssector, 2001

\begin{tabular}{lrlll}
\hline Opleidingssector & Aantal & Percentage & Typering \\
\hline & & & \\
\hline Basisonderwijs & 22.000 & 5,1 & hoog \\
VMBO theorie & 22.000 & 5,0 & hoog \\
VMBO landbouw en techniek & 17.500 & 3,6 & laag \\
VMBO economie & 10.000 & 7,0 & erg hoog \\
VMBO verzorging & 7.000 & 3,8 & gemiddeld \\
HAVO/WWO & 27.500 & 8,0 & erg hoog \\
MBO landbouw en techniek & 37.000 & 3,3 & laag \\
MBO economie & 35.000 & 4,1 & gemiddeld \\
MBO dienstverlening en gezondheidszorg & 31.000 & 4,2 & gemiddeld \\
HBO landbouw en techniek & 11.500 & 4,0 & gemiddeld \\
HBO economie & 18.500 & 6,2 & hoog \\
HBO onderwijs en sociaal-cultureel & 16.000 & 3,0 & laag \\
HBO paramedisch & 4.000 & 3,3 & laag \\
WO landbouw en techniek & 5.500 & 4,4 & gemiddeld \\
WO economie & 9.500 & 5,2 & hoog \\
WO letteren en sociaal-cultureel & 8.000 & 4,8 & gemiddeld \\
WO medisch & 1.500 & 2,3 & erg laag \\
Totaal & 291.000 & 4,3 & - \\
& & & & \\
\hline
\end{tabular}

\section{Bron: ROA}

Tabel 4.10 geeft een overzicht van het aantal schoolverlaters per opleidingssector. De totale instroom in 2001 zal 4,3\% van het aantal werkenden bedragen. Er zijn echter duidelijke verschillen tussen de opleidingssectoren. Er wordt een relatief hoge 
instroom van schoolverlaters verwacht voor de drie economische opleidingssectoren VMBO economie, HBO economie en WO economie. Ook de algemene, voorbereidende opleidingen VMBO theorie en HAVONWO geven een hoge verwachte instroom op de arbeidsmarkt te zien. Op zich is dat laatste een bedenkelijke ontwikkeling: deze schoolverlaters hebben nauwelijks meer dan een basale opleiding en zullen zich moeten richten op laag en ongeschoold werk. Daarentegen is er een relatief lage instroom vanuit de agrarische en medische opleidingssectoren. Voor de agrarische opleidingssectoren geldt waarschijnlijk dat dit het gevolg is van een teruglopende interesse in de opleiding die mogelijk mede is gebaseerd op de verwachting dat de werkgelegenheid in de agrarische sector kleiner aan het worden is. Voor de medische opleidingen moet het lage aantal schoolverlaters mogelijk gezocht worden in de beperking van het aantal opleidingsplaatsen dat de afgelopen jaren heeft plaatsgehad.

Een aparte alinea moet besteed worden aan het aantal schoolverlaters met uitsluitend Basisonderwijs. In totaal zijn er 22.000 mensen, 5,1\% van het aantal werkenden, met uitsluitend deze opleiding. Op die manier gepresenteerd klinkt dat niet zo ernstig. Veel ernstiger komt het over als dit aantal gerelateerd wordt aan het totaal aantal schoolverlaters in 2001: deze groep vormt bijna $8 \%$ van het aantal schoolverlaters. Hoewel het in de data niet is na te gaan, is het merendeel van deze ongeschoolde schoolverlaters waarschijnlijk te wijten aan uitval op het VMBO. In een tijd waarin gesproken wordt over de startkwalificatie voor alle schoolverlaters, is het bedenkelijk dat het onderwijssysteem er blijkbaar niet in slaagt deze mensen aan een opleiding op VMBO-niveau te helpen. Te vrezen valt dat het aantal drop-outs alleen maar toe zal nemen als de druk toeneemt om een MBO- in plaats van een VMBO-opleiding te gaan volgen. In dat geval zal een actie om meer mensen naar het MBO te helpen wel eens averechts uit kunnen pakken, omdat het voor een deel van de scholieren 'te veel gevraagd is' en ze de school zullen verlaten voordat ze hun opleiding afgerond hebben.

Voor werkgevers is naast de vraag welke opleidingsrichting schoolverlaters hebben, ook de vraag van belang in welke beroepssector deze schoolverlaters zich zullen aanbieden. Immers: als de instroom van een bepaald opleidingstype voldoende is, maar zij zich niet aanbieden in een sector waar er behoefte aan is, ontstaan er voor werkgevers in deze beroepssector nog steeds knelpunten. Op basis van SIS kan een indicatie verkregen worden over de beroepssectoren waar de schoolverlaters zich zullen aanbieden. Net zoals dit voor de overige stromen in het model gebeurd is, wordt de verdeling van de schoolverlaters over de diverse beroepssectoren gerelateerd aan het opleidingsniveau, de opleidingsrichting, het geslacht en de leeftijd van de schoolverlaters. Een nadeel van deze methode is dat de verdeling van schoolverlaters in het verleden ook sterk bepaald is door de arbeidsmarktmogelijkheden in de diverse sectoren. De waargenomen verdeling is naar alle waarschijnlijkheid niet puur de verdeling van het aanbod geweest maar mede het gevolg van de vraag, en de aanpassingen die er - van twee zijden - plaatsgevonden hebben als gevolg van de vraag-aanbodverhouding per beroepssector. $\mathrm{Er}$ is echter op basis van de huidige gegevens geen betere methode voorhanden. Gevolg hiervan is wel dat de 
prognose van het aanbod van schoolverlaters naar beroepssector als indicatief beschouwd moet worden, en relatief grote onzekerheidsmarges zal kennen.

In tabel 4.11 wordt het verwachte aanbod van schoolverlaters naar beroepssector gepresenteerd, zoals dat op basis van het stromenmodel is bepaald. Het totale aanbod van schoolverlaters is $4,3 \%$. De ene beroepssector kent echter een veel groter aanbod van schoolverlaters dan de andere. Zo wordt er in de transportberoepen een aantal schoolverlaters verwacht dat slechts $1,5 \%$ van het totaal aantal werkenden in de sector uitmaakt, terwijl dit in de openbare orde- en veiligheidsberoepen ongeveer $9 \%$ is. Blijkbaar zijn lang niet alle sectoren even populair bij de schoolverlaters, of zijn er in sommige sectoren nauwelijks mogelijkheden voor schoolverlaters. De mate waarin schoolverlaters voor werkgevers van belang zijn, hangt immers ook samen met de behoefte van werkgevers aan pas opgeleide mensen. Zo zullen in beroepssectoren waarin veel technologische ontwikkelingen plaatsvinden schoolverlaters een veel grotere rol spelen dan in andere. Ook zullen sectoren waarin het werk fysiek belastend is in principe meer schoolverlaters een plek vinden. Zoals gezegd kunnen de percentages vanwege de gehanteerde methodiek ook beïnvloed zijn door de mogelijkheden die deze sectoren in het verleden boden.

Tabel 4.11

Instroom van schoolverlaters per beroepssector, 2001

\begin{tabular}{lrrl}
\hline & & & \\
Beroepssector & Aantal & Percentage & Typering \\
& & & \\
\hline & 8.500 & 2,4 & laag \\
Pedagogische beroepen & 3.000 & 2,6 & laag \\
Culturele beroepen & 9.000 & 3,7 & gemiddeld \\
Agrarische beroepen & 58.500 & 3,8 & gemiddeld \\
Technische en industrieberoepen & 6.000 & 1,5 & erg laag \\
Transportberoepen & 19.000 & 4,8 & gemiddeld \\
Medische en paramedische beroepen & 91.000 & 4,4 & gemiddeld \\
Economisch-administratieve beroepen & 12.500 & 5,4 & hoog \\
Informaticaberoepen & 12.000 & 6,1 & hoog \\
Sociaal-culturele beroepen & 63.000 & 6,1 & erg hoog \\
Verzorgende en dienstverlenende beroepen & 9.000 & 9,1 & erg hoog \\
Openbare orde- en veiligheidsberoepen & & & \\
& 291.000 & 4,3 & - \\
Totaal & & &
\end{tabular}

Bron: ROA

\subsection{Instroom van herintreders op de arbeidsmarkt}

In hoofdstuk 3 is al stilgestaan bij de mogelijkheden die er voor herintreders bestaan op de arbeidsmarkt. Hoewel niet duidelijk is welke plaats zij innemen in de voorkeuren van de werkgevers, blijken ze wel degelijk aan het werk te kunnen komen. Ofwel er zijn situaties waarin een herintreder beter voldoet dan een schoolverlater, ofwel de situatie op de arbeidsmarkt is dermate krap (aan het worden) dat werkgevers niet anders kunnen dan mensen aan te nemen die aan de zijlijn van de arbeidsmarkt staan. In paragraaf 3.5, waarin op basis van het Sociaal-Economisch Panel de instroom beschreven werd, bleek dat in de jaren '94 tot '96 de groep 
herintreders afkomstig uit werkloosheid of non-participatie ongeveer even groot was als de groep schoolverlaters. Herintreders vormen op het eerste gezicht in alle lagen van de arbeidsmarkt een bruikbaar potentieel en ook in opleidingsrichtingen met een minder goed perspectief blijken er nog vrij veel herintreders te zijn. Herintreders kenmerken zich over het algemeen wel door hun relatief lage opleidingsniveau, maar in hoofdstuk 3 bleek dat men er desondanks in slaagt werk te vinden in vrijwel alle beroepssectoren. De relatief lage scholingsgraad van de herintreders heeft waarschijnlijk wel tot gevolg dat ze voornamelijk in niet-specialistische beroepen terecht zullen komen.

Op basis van de waargenomen instroom uit de niet-participerenden kan voor het prognosejaar een verwachting opgesteld worden van het aantal herintreders per beroepssector en per opleidingssector. Omdat de prognoses gebaseerd zijn op de waargenomen intredekansen, gerelateerd aan kenmerken als leeftijd en opleiding, gaan we er van uit dat een dergelijke instroom zoals is waargenomen in het verleden ook in de toekomst gerealiseerd kan worden. Hierbij wordt dus deels voorbijgegaan aan het feit dat er tot een aantal jaren terug sprake was van een vrij groot 'stuwmeer' van niet-participerenden die over de juiste kwalificaties beschikten maar zich niet beschikbaar stelden voor de arbeidsmarkt. Dit stuwmeer is echter aan het 'leeglopen' waardoor de gemiddelde kwaliteit van de niet-participerenden waarschijnlijk aan het afnemen is. Voor zover deze kwaliteit weerspiegeld wordt door opleiding en leeftijd wordt het effect van deze kwaliteitsafname verrekend met de prognoses. Het feit dat binnen bepaalde opleidingscategorieën de besten al weg zijn wordt echter niet met de prognoses verrekend. Het gevolg van dit selectie-effect kan zijn dat het steeds minder goed mogelijk is om herintreders in te zetten in een bedrijf. Het gevolg daarvan kan weer zijn dat op de langere termijn het belang van de instroom van herintreders zal afnemen. Er zijn echter nog steeds vrij veel mensen - met name vrouwen - die ongeacht hun opleiding of ervaring de arbeidsmarkt verlaten om persoonlijke redenen. Deze uitstroom naar de niet-participerenden zal de kwaliteit van de groep niet-participerenden waarschijnlijk groot genoeg houden om ook voor de langere termijn de inzetbaarheid van herintreders te waarborgen.

In tabel 4.12 wordt het verwachte aanbod van herintreders gepresenteerd per beroepssector $^{13}$. In totaal is er een verwacht aanbod van $3,1 \%$ te zien. Dit is lager dan het aanbod uit de baanwisselaars dat $6,5 \%$ bedraagt. Het is ook lager dan het aanbod van schoolverlaters dat $4,3 \%$ van het aantal werkenden bedraagt. Als dit vergeleken wordt met de verhoudingen die in hoofdstuk 3 bepaald zijn op basis van de historische instroom, dan kan geconcludeerd worden dat er een verschuiving aan het optreden is. Over de afgelopen jaren bestond bijna $60 \%$ van de instroom uit baanwisselaars, $20 \%$ uit schoolverlaters en $20 \%$ uit herintreders. In de prognoses lijkt de verhouding van het aanbod anders te liggen: in het aanbod is vooral het belang van de schoolverlaters groter 'ten koste' van de baanwisselaars: in het

13. Merk op dat het strikt genomen het aantal niet-particperenden is dat bereid is om in het prognosejaar te gaan werken (zich 'aanbiedt' op de arbeidsmarkt). Pas zodra er van hun bereidheid gebruik gemaakt wordt door een werkgever en ze daadwerkelijk gaan werken kun je spreken van een herintreder. 
aanbod wordt $47 \%$ gevormd door baanwisselaars, $31 \%$ door schoolverlaters, en $22 \%$ door herintreders.

Tabel 4.12

Aanbod van herintreders per beroepssector, 2001

\begin{tabular}{|c|c|c|c|}
\hline Beroepssector & Aantal & Percentage & Typering \\
\hline $\begin{array}{l}\text { Pedagogische beroepen } \\
\text { Culturele beroepen } \\
\text { Agrarische beroepen } \\
\text { Technische en industrieberoepen } \\
\text { Transportberoepen } \\
\text { Medische en paramedische beroepen } \\
\text { Economisch-administratieve beroepen } \\
\text { Informaticaberoepen } \\
\text { Sociaal-culturele beroepen } \\
\text { Verzorgende en dienstverlenende beroepen } \\
\text { Openbare orde- en veiligheidsberoepen }\end{array}$ & $\begin{array}{r}8.000 \\
2.500 \\
7.500 \\
42.500 \\
10.000 \\
7.500 \\
46.000 \\
5.500 \\
5.500 \\
65.500 \\
0\end{array}$ & $\begin{array}{l}2,2 \\
2,1 \\
3,1 \\
2,8 \\
2,6 \\
1,9 \\
2,2 \\
2,3 \\
2,7 \\
6,4 \\
0,0\end{array}$ & $\begin{array}{l}\text { gemiddeld } \\
\text { laag } \\
\text { erg hoog } \\
\text { hoog } \\
\text { gemiddeld } \\
\text { laag } \\
\text { gemiddeld } \\
\text { gemiddeld } \\
\text { hoog } \\
\text { erg hoog } \\
\text { erg laag }\end{array}$ \\
\hline Totaal & 209.500 & 3,1 & - \\
\hline
\end{tabular}

Bron: ROA

Omdat herintreders met name vrouwen van middelbare leeftijd zijn, valt er een correlatie te verwachten tussen het aantal vrouwen dat in een sector werkt en het aanbod van herintreders. Dit zou leiden tot het grootste aanbod bij de 'typische vrouwenberoepen'. Hoewel over het algemeen de groep herintreders in hoge mate wordt gevormd door vrouwen, valt zo'n patroon echter niet te herkennen in de herintrede. Wel is er één sector die opvalt door een zeer hoog aantal herintreders: de sector verzorgende en dienstverlenende beroepen. Hier wordt een aanbod van $6,4 \%$ verwacht. De overige sectoren hebben een veel lager verwacht aanbod van herintreders, tussen de twee en drie procent. Het laagste aantal herintreders komt voor bij de medische en paramedische beroepen, die een instroom kennen van $1,9 \%$. Dit is waarschijnlijk het gevolg van het feit dat er voor zeer veel van deze beroepen sprake is van een hoge belasting (werkdruk), of moeilijkheden om het werk in deeltijd uit te voeren (o.a. verplegend personeel heeft daar zeer vaak moeite mee). Dit verlaagt de animo om zich als herintreder in zo'n sector aan te bieden aanzienlijk. Als men in dat geval al terugkeert op de arbeidsmarkt, zal men dat in een andere sector doen ${ }^{14}$. Voor de beroepen uit de beroepssector openbare orde en veiligheid geldt een zelfde redenering: daar komt ook nog bij dat in die sector de werkgevers waarschijnlijk een zeer sterke voorkeur hebben voor jongere werknemers, omdat deze fysiek sterker zijn. Merk op dat omdat de groep herintreders in de verzorgende en dienstverlenende beroepen erg groot is, ook het landelijke totaalpercentage erg hoog ligt. Doordat de typering van de percentages een relatieve typering is, heeft dit tot gevolg dat het

14. Het aantal herintreders bij de openbare orde- en veiligheidsberoepen ligt nog lager $(0,0 \%)$. De vraag is echter hoe betrouwbaar dit cijfer is: de groep is in het SEP erg klein, zodat er maar zeer weinig waarnemingen beschikbaar waren om de stromen op te schatten. Het gevolg is dat de betrouwbaarheidsmarges bij deze groep erg groot zijn. 
landelijk gemiddelde niet de typering 'gemiddeld' zou krijgen, maar de typering 'erg hoog'.

Er kan ook gekeken worden naar het aanbod van herintreders naar opleidingssector. Deze cijfers worden gepresenteerd in Tabel 4.13. Gezien het feit dat veel nietparticiperenden een relatief lage opleidingsachtergrond hebben, is het ook niet verwonderlijk dat het aanbod van herintreders zich ook concentreert op de lagere opleidingsniveaus. Vooral Basisondenwijs en VMBO economie kennen een groot aanbod van herintreders. Verder valt de hoge instroom voor VMBO verzorging en in mindere mate $M B O$ dienstverlening en gezondheidszorg op. In tegenstelling tot de instroom van herintreders naar beroepssector, kunnen we per opleidingssector dus aanmerkelijk beter een 'vrouwelijke' component herkennen. $\mathrm{Er}$ is ook een verband te zien tussen deze tabel en de vorige: de mensen uit deze beide opleidingen zullen zich in eerste instantie richten op de beroepen in de sector verzorgende en dienstverlenende beroepen. Het aanbod van herintreders op het HBO- en WO-niveau is veel lager, hetgeen vooral toegeschreven moet worden aan het feit dat er vrijwel geen niet-participerenden op dit niveau beschikbaar zijn. Voor zover deze er wel zijn, zien ze er blijkbaar van af om zich aan te bieden. Dit zou mede veroorzaakt kunnen worden door het feit dat ze ondervonden hebben geen kans te maken op de arbeidsmarkt, omdat werkgevers geen HBO-ers of WO-ers aannemen die in een periode van een krappe arbeidsmarkt gedurende langere tijd langs de zijlijn gestaan hebben.

Tabel 4.13

Aanbod van herintreders per opleidingssector, 2001

\begin{tabular}{lrrl}
\hline Opleidingssector & Aantal & Percentage & Typering \\
\hline Basisonderwijs & 43.000 & 9,9 & erg hoog \\
VMBO theorie & 19.000 & 4,4 & hoog \\
VMBO landbouw en techniek & 13.000 & 2,7 & gemiddeld \\
VMBO economie & 10.000 & 6,8 & erg hoog \\
VMBO verzorging & 12.500 & 6,7 & hoog \\
HAVONWO & 17.000 & 5,0 & hoog \\
MBO landbouw en techniek & 11.500 & 1,0 & erg laag \\
MBO economie & 15.000 & 1,8 & gemiddeld \\
MBO dienstverlening en gezondheidszorg & 26.500 & 3,6 & hoog \\
HBO landbouw en techniek & 4.500 & 1,5 & laag \\
HBO economie & 3.500 & 1,2 & laag \\
HBO onderwijs en sociaal-cultureel & 14.000 & 2,6 & gemiddeld \\
HBO paramedisch & 1.500 & 1,2 & laag \\
WO landbouw en techniek & 4.500 & 3,5 & gemiddeld \\
WO economie & 3.000 & 1,8 & gemiddeld \\
WO letteren en sociaal-cultureel & 4.500 & 2,7 & gemiddeld \\
WO medisch & 500 & 1,0 & laag \\
Totaal & 209.500 & 3,1 & \\
& & & \\
\hline Bron: ROA & & &
\end{tabular}

Bron: ROA

Het feit dat de meeste herintreders een lagere opleidingsachtergrond hebben betekent dat het grote reservoir aan niet-participerenden niet per definitie geschikt is om 
alle knelpunten op de arbeidsmarkt op te vullen. Deze groep kan namelijk geen soelaas bieden wanneer de problemen in de personeelsvoorziening zich voordoen op een middelbaar of hoger niveau. Willen de niet-participerenden op een geloofwaardige manier in aanmerking komen voor emplooi in hogere sectoren, dan zal men zich moeten om- en/of bijscholen om meer aan de gestelde eisen van de werkgevers te kunnen voldoen. In hoeverre men hiertoe bereid is, is moeilijk aan te geven. Een andere oplossing om door middel van lager opgeleiden de knelpunten op de hogere niveaus op te lossen is door gebruik te maken van het reeds meermalen genoemde cascademodel. Hierbij moeten werkgevers er voor zorgen dat zij intern werknemers van de lagere beroepsniveaus opleiden en door laten stromen naar de hogere niveaus. Dit zal er vervolgens in resulteren dat er plaatsen vrijkomen op het (lagere) aanvangsniveau. Omdat de eisen die nu aan de 'nieuwkomers' gesteld worden lager zijn, wordt het mogelijk om op deze plaatsen wel (lager opgeleide) herintreders te plaatsen. Nader onderzoek zou uit moeten wijzen in hoeverre de waargenomen instroom uit het verleden op deze wijze gerealiseerd is.

\subsection{Spanning op de arbeidsmarkt}

De informatie uit alle voorgaande tabellen kan samengenomen worden zodat een indicatie verkregen kan worden van de verwachte situatie op de arbeidsmarkt. De totale vraag naar arbeidskrachten is de som van de uitbreidingsvraag en de bruto vervangingsvraag. Omdat voor deze prognoses het perspectief voor alle werkzoekenden als uitgangspunt genomen is, wordt bij de uitbreidingsvraag ook de negatieve uitbreidingsvraag meegeteld, net zoals dit nu voor het bepalen van de indicator van de toekomstige knelpunten in de personeelsvoorziening (ITKP) in De arbeidsmarkt naar opleiding en beroep ook al gebeurt. De totale vraag naar arbeidskrachten kan dus negatief worden als de werkgelegenheidskrimp groter is dan de vervangingsvraag. Een dergelijke negatieve vraag zal leiden tot gedwongen ontslag of een verhoogde baanmobiliteit van mensen die dit ontslag niet afwachten. Tegenover de totale vraag staat het totale aanbod, dat bestaat uit de mensen die van baan veranderen, de schoolverlaters en de herintreders ${ }^{15}$. Deze totale vraag naar en het totale aanbod van arbeidskrachten kunnen dan met elkaar geconfronteerd worden teneinde een indicatie te krijgen van de spanning op de arbeidsmarkt.

De confrontatie van vraag en aanbod per beroepssector levert een indicatie op van de spanning op de arbeidsmarkt die er zich voor het desbetreffende beroep voor zal doen. In Tabel 4.14 staat voor het jaar 2001 de Indicator van de Spanning op de Arbeidsmarkt (ISA) weergegeven per beroepssector. Uit de laatste regel van de tabel valt op te maken dat er over de hele arbeidsmarkt - nog afgezien van de mismatch tussen vraag en aanbod voor de verschillenden sectoren - sprake zal zijn van een tekort aan arbeidskrachten: de ISA is (iets) kleiner dan 1, dus wordt er een (klein) tekort verwacht. Dit tekort doet zich niet in alle sectoren even sterk voor. Aan de ene kant zijn er sectoren met een groot tekort zoals de transportberoepen en in mindere

15. Tabellen met gegevens over totale vraag en totaal aanbod kunnen gevonden worden in de Statistische Bijlage die bij dit rapport behoort. 
mate de verzorgende en dienstverlenende beroepen. In deze twee sectoren zal zich een relatief groot tekort voordoen wat tot (zeer) grote knelpunten in de personeelsvoorziening zal leiden voor de werkgevers. Het directe gevolg hiervan is dat deze sectoren voor werkzoekenden (zeer) goede kansen op werk bieden, mits men natuurlijk over de juiste kwalificaties beschikt. Aan de andere kant zijn er ook sectoren waar een evenwicht of zelfs een klein overschot aan werkenden verwacht wordt. In de technische en industrieberoepen zijn vraag en aanbod naar verwachting even groot, net zoals in de informaticaberoepen en de beroepssector openbare orde en veiligheid. Voor de medische en paramedische beroepen wordt zelfs een klein overschot verwacht!

Tabel 4.14

Indicator Spanning op de Arbeidsmarkt (ISA) per beroepssector, 2001

\begin{tabular}{|c|c|c|c|}
\hline Beroepssector & ISA & $\begin{array}{l}\text { Knelpunten voor } \\
\text { de werkgever }\end{array}$ & $\begin{array}{l}\text { Perspectief voor de } \\
\text { werkzoekende }\end{array}$ \\
\hline $\begin{array}{l}\text { Pedagogische beroepen } \\
\text { Culturele beroepen } \\
\text { Agrarische beroepen } \\
\text { Technische en industrieberoepen } \\
\text { Transportberoepen } \\
\text { Medische en paramedische beroepen } \\
\text { Economisch-administratieve beroepen } \\
\text { Informaticaberoepen } \\
\text { Sociaal-culturele beroepen } \\
\text { Verzorgende en dienstverlenende beroepen } \\
\text { Openbare orde- en veiligheidsberoepen }\end{array}$ & $\begin{array}{l}0,99 \\
0,97 \\
0,99 \\
1,00 \\
0,95 \\
1,02 \\
0,98 \\
1,00 \\
0,99 \\
0,97 \\
1,00\end{array}$ & $\begin{array}{l}\text { enige } \\
\text { groot } \\
\text { enige } \\
\text { enige } \\
\text { zeer groot } \\
\text { vrijwel geen } \\
\text { groot } \\
\text { enige } \\
\text { enige } \\
\text { groot } \\
\text { enige }\end{array}$ & $\begin{array}{l}\text { redelijk } \\
\text { goed } \\
\text { redelijk } \\
\text { redelijk } \\
\text { zeer goed } \\
\text { matig } \\
\text { goed } \\
\text { redelijk } \\
\text { redelijk } \\
\text { goed } \\
\text { redelijk }\end{array}$ \\
\hline Totaal & 0,99 & enige & redelijk \\
\hline
\end{tabular}

Bron: ROA

Vooral dit verwachte overschot in de medische en paramedische beroepen roept vragen op, want de ervaring van werkgevers in de zorg is dat de mensen niet of nauwelijks te vinden zijn, en dat het aantal (zeer) moeilijk vervulbare vacatures erg hoog is. Diezelfde ervaringen heeft men ook in de technische sector. Er moeten bij deze cijfers dan ook een aantal zaken in het oog gehouden worden. Ten eerste wordt er bij de confrontatie van vraag en aanbod geen rekening gehouden met de kwalitatieve match tussen vraag en aanbod. Er kan dus achter de cijfers een kwalitatieve mismatch tussen vraag en aanbod schuilgaan als de mensen die zich aanbieden voor de diverse beroepen niet of in onvoldoende mate beschikken over de gevraagde en noodzakelijke kwalificaties. In dat geval lijkt er op basis van de getalsmatige match tussen vraag en aanbod geen sprake te zijn van knelpunten maar zijn ze er wel degelijk. Zoals zal blijken uit de resultaten per opleidingstype wordt het verwachte overschot in de medische sector veroorzaakt door aanbod van werkzoekenden die niet over de juiste opleidingsachtergrond beschikken en is het probleem voor de sector dus veel groter dan Tabel 4.14 suggereert. Deze kwalitatieve mismatch tussen vraag en aanbod per beroepsgroep maakt dat de cijfers per beroepsgroep met de nodige voorzichtigheid beschouwd moeten worden. Eigenlijk maakt dit duidelijk dat er per beroepsgroep een onderverdeling naar 
opleiding, en in ieder geval naar opleidingsniveau gemaakt zal moeten worden. Pas dan wordt duidelijk of het aanbod over de gevraagde kwalificaties beschikt. En ook kan dan duidelijk worden wat voor de diverse sectoren de meest effectieve manier is om de knelpunten op te lossen.

Een tweede kanttekening die bij de gepresenteerde tekorten gemaakt moet worden is dat de nu openstaande vacatures per beroep niet bij de vraag zijn meegeteld. Het gevolg hiervan is een mogelijke onderschatting van de vraag, waardoor er sprake lijkt te zijn van zeer beperkte tekorten die in de praktijk wel eens groter zouden kunnen zijn. Het opnemen van vacaturecijfers in het stromenmodel gaat de mogelijkheden van het model nu echter nog te boven, maar verdient op termijn wel alle aandacht. De derde kanttekening bij de cijfers is dat het hier geaggregeerde cijfers over alle beroepen binnen een sector betreft. Het gevolg hiervan is dat onevenwichtigheden in vraag en aanbod binnen de beroepssector verdwijnen. Om een voorbeeld te geven: het zou kunnen dat er in de medische beroepen een overschot is van 100 artsen en een tekort van 100 apothekersassistenten. Geaggregeerd zijn vraag en aanbod dan echter aan elkaar gelijk. In de Statistische Bijlage zijn ook cijfers gepresenteerd voor de afzonderlijke beroepen ${ }^{16}$. Bij nadere beschouwing van deze cijfers op laag aggregatieniveau lijkt er echter binnen de zorg geen sprake te zijn van een grote mismatch. Wel is het zo dat het overschot voor een groot deel toegeschreven moet worden aan het relatief grote aantal schoolverlaters en niet-participerenden die een baan als verpleeghulp of leerling-verpleegkundige zou willen hebben. Een vierde punt wat genoemd kan worden betreft de mobiliteit die in de diverse sectoren optreedt. Het kan zijn dat vraag en aanbod met elkaar in evenwicht zijn, maar er wel een erg hoge baanmobiliteit optreedt. Het gevolg hiervan is dat de werkgever voortdurend geconfronteerd wordt met een hoge uitstroom van personeel. Dit heeft tot gevolg dat er regelmatig sprake is van openstaande vacatures, zodat iedere individuele werkgever de indruk krijgt dat er sprake is van een zeer groot tekort aan werknemers. Het feitelijke, geaggregeerde tekort zou echter wel eens veel lager kunnen zijn dan het gepercipieerde tekort. Dit effect zal echter bij de medische beroepen slechts een kleine rol spelen, omdat daar juist sprake is van een relatief lage uitstroom.

Door per opleidingssector de vraag en aanbodcomponenten naast elkaar te zetten, krijgen we een beeld van de discrepanties per opleidingssector. Tabel 4.15 geeft het overzicht van de spanning op de arbeidsmarkt per opleidingssector. Ook nu is er uiteraard weer sprake van een klein geaggregeerd tekort. De verschillen per opleidingssector zijn nog kleiner dan de verschillen tussen de beroepssectoren. $\mathrm{Er}$ vallen eigenlijk maar twee sectoren op. Allereerst is dat de opleidingssector Basisonderwijs. Deze sector kent voor 2001 een groot overschot aan arbeidskrachten. Het gevolg hiervan is dat werkzoekenden die ongeschoold zijn zeer veel problemen

16. Bij deze cijfers op beroepsniveau moet bedacht worden dat ze afgeleid zijn van de cijfers op sectorniveau. De verschillen tussen de beroepen binnen de sectoren worden daardoor enigszins onderschat. Het gevolg hiervan is dat de cijfers op beroepsniveau een relatief grote onzekerheidsmarge hebben. Dit geldt ook voor de in de Statistische Bijlage gepresenteerde cijfers op het niveau van opleidingstype. 
zullen ondervinden met het vinden van een baan. Dit geldt ook voor de opleidingssector VMBO economie. Ook hier is sprake van een groot overschot aan (potentiële) arbeidskrachten. Dit lijkt in tegenspraak met het eerder geconstateerde feit dat er nog steeds een grote instroom van ongeschoolden op de arbeidsmarkt plaatsheeft, en dat er dus nog steeds mogelijkheden zijn. Het slechte perspectief voor werkzoekenden komt dan ook niet voort uit een lage vraag, maar veel meer uit een aanbod dat erg hoog is.

De grootste tekorten aan arbeidskrachten doen zich voor op het niveau van MBO en $\mathrm{HBO}$, de tekorten op WO-niveau daarentegen zijn relatief beperkt (ca. 1 à $1,5 \%$ van het totaal aantal werkenden). Vooral MBO landbouw en techniek en MBO dienstverlening en gezondheidszorg kennen een relatief groot tekort aan arbeidskrachten. Dit plaatst de cijfers uit de vorige tabel in een heel ander perspectief: er mag dan binnen de beroepssector medische en paramedische beroepen geen tekort zijn, er is een zeer groot tekort aan mensen met een medische of paramedische opleiding. Ditzelfde geldt dus ook voor de technische opleidingen op MBO niveau. Dit suggereert dat hoewel het aantal mensen dat zich richt op de diverse beroepssectoren groot genoeg is, zij absoluut niet over de juiste kwalificaties beschikken. Als in Tabel 4.1 $\mathrm{E}$ gekeken wordt wat de opleidingssectoren zijn die een tekort kennen dat lager ligt dan het gemiddelde is te zien dat dit de sectoren Basisonderwijs, VMBO economie, HBO economie en WO landbouw en techniek zijn. Mensen die een dergelijke opleiding gevolgd hebben, bieden zich blijkbaar 'vrij breed' op de arbeidsmarkt aan, wat bij de cijfers op beroepsniveau de - verkeerde - suggestie wekt dat er sprake is van een evenwicht. Aan de andere kant valt het in de tabel op dat een andere relatief lage en vrij algemene opleiding een tekort kent: VMBO theorie (de vroegere MAVO) kent een flink tekort. Naar alle waarschijnlijkheid liggen op deze plekken de beste mogelijkheden voor werkzoekenden met alleen Basisondenwijs.

Bij de tekorten zoals ze in deze paragraaf gepresenteerd zijn, moet ook bedacht worden dat er in het aanbod van arbeidskrachten een relatief grote groep herintreders is opgenomen (ca. $20 \%$ van het totale aanbod). Het aannemen van een herintreder is echter heel vaak het gevolg van een actieve wervingsstrategie van werkgevers. Met andere woorden, dit aanbod is geen aanbod 'dat vanzelf komt'. Heel vaak moeten niet-participerenden actief benaderd worden om ze er toe over te halen weer te gaan werken (een strategie die op het ogenblik in het onderwijs toegepast wordt). Ook zijn er soms aanpassingen nodig op het gebied van werktijden en arbeidsvoorwaarden. Zo kunnen veel vrouwen pas opnieuw intreden als de werktijden afgestemd kunnen worden op de thuissituatie, en als er voldoende kinderopvang aanwezig is. Dit zal betekenen dat 'flexibele arbeid' in toenemende mate zal betekenen dat niet alleen de werknemer 'zich schikt' naar de wensen van de werkgever, maar ook andersom: de werkgever zal zich in toenemende mate moeten laten leiden door de wensen van de (potentiële) werknemer! De cijfers in tabellen 4.16 en 4.17 laten weliswaar zien dat er geen grote tekorten zijn, maar dat betekent dus niet dat alles vanzelf gaat. Er zal dus zeker actie ondernomen moeten worden om de grote groep niet-participerenden die in principe kan gaan werken ook daadwerkelijk aan het werk te krijgen! 
Tabel 4.15

Indicator Spanning op de Arbeidsmarkt (ISA) per opleidingssector, 2001

\begin{tabular}{|c|c|c|c|}
\hline Opleidingssector & ISA & $\begin{array}{l}\text { Knelpunten voor } \\
\text { de werkgever }\end{array}$ & $\begin{array}{l}\text { Perspectief voor de } \\
\text { werkzoekende }\end{array}$ \\
\hline $\begin{array}{l}\text { Basisonderwijs } \\
\text { VMBO theorie } \\
\text { VMBO landbouw en techniek } \\
\text { VMBO economie } \\
\text { VMBO verzorging } \\
\text { HAVONWO } \\
\text { MBO landbouw en techniek } \\
\text { MBO economie } \\
\text { MBO dienstverlening en gezondheidszorg } \\
\text { HBO landbouw en techniek } \\
\text { HBO economie } \\
\text { HBO onderwijs en sociaal-cultureel } \\
\text { HBO paramedisch } \\
\text { WO landbouw en techniek } \\
\text { WO economie } \\
\text { WO letteren en sociaal-cultureel } \\
\text { WO medisch }\end{array}$ & $\begin{array}{l}1,10 \\
0,95 \\
1,00 \\
1,07 \\
0,97 \\
0,99 \\
0,97 \\
0,98 \\
0,98 \\
0,99 \\
1,00 \\
0,98 \\
0,96 \\
1,00 \\
0,99 \\
0,99 \\
0,98\end{array}$ & $\begin{array}{l}\text { geen } \\
\text { groot } \\
\text { enige } \\
\text { geen } \\
\text { groot } \\
\text { enige } \\
\text { groot } \\
\text { groot } \\
\text { groot } \\
\text { enige } \\
\text { enige } \\
\text { groot } \\
\text { groot } \\
\text { enige } \\
\text { enige } \\
\text { enige } \\
\text { groot }\end{array}$ & $\begin{array}{l}\text { slecht } \\
\text { goed } \\
\text { redelijk } \\
\text { slecht } \\
\text { goed } \\
\text { redelijk } \\
\text { goed } \\
\text { goed } \\
\text { goed } \\
\text { redelijk } \\
\text { redelijk } \\
\text { goed } \\
\text { goed } \\
\text { redelijk } \\
\text { redelijk } \\
\text { redelijk } \\
\text { goed }\end{array}$ \\
\hline Totaal & 0,99 & enige & redelijk \\
\hline
\end{tabular}

Bron: ROA

\subsection{Oplossingen voor de verwachte knelpunten}

Wanneer voor een bepaalde plaats geen of niet voldoende geschikt personeel beschikbaar is, dan zal een werkgever zich tot andere groepen op de arbeidsmarkt moeten richten, maar dit is natuurlijk geen garantie dat hiermee de problemen zijn opgelost. Het gegeven dat men zich van anderen zal moeten bedienen bij het invullen van vacatures alleen is namelijk niet voldoende. Het spreekt voor zich dat het geen zin heeft te verwachten dat je de laagst en meest algemeen opgeleiden snel en kosteloos kunt omvormen tot breed inzetbare, hoger opgeleiden. In deze paragraaf zal duidelijk worden dat een meer realistische en gematigde kijk op de mogelijkheden van om- en bijscholing wellicht verstandiger is.

Schema 4.1 is gebaseerd op een schema uit De Grip e.a. (1999a) en geeft aan welke mogelijke aanpassingsprocessen er in geval van knelpunten in de personeelsvoorziening kunnen worden gevolgd. Per mogelijkheid is tevens aangegeven in hoeverre de aanpassing effect heeft op de drie afzonderlijke aanbodgroepen (schoolverlaters, werklozen en niet-participerenden). Uiteraard zijn er ook andere mogelijkheden die niet in de sfeer van het personeelsbeleid liggen, maar meer op het gebied van de organisatie van het productieproces. Zo kunnen werkgevers ook overgaan tot functiesplitsing: het productieproces zo inrichten dat hoger opgeleiden (vrijwel) geen taken meer verrichten die ook door lager opgeleiden verricht kunnen worden. Op die manier is het ook mogelijk de vraag naar hoger opgeleiden zo laag mogelijk te houden en zo de knelpunten te verminderen. In deze paragraaf wordt verder alleen ingegaan op de aanpassingen in de sfeer van het personeelsbeleid. 
Schema 4.1

Mogelijke aanpassingsprocessen bij knelpunten in de personeelsvoorziening

Mogelijkheden

Doelgroepen

Schoolverlaters Werklozen Niet-

participerenden

Rekruteren werknemer die elders werkzaam is

Aantrekken van personeel uit het buitenland

Omscholing van het eigen personeel

Aannemen personeel met een andere opleidingsachtergrond

Bijscholing van het eigen personeel

Aannemen van te laag geschoold personeel

Aantrekken vanuit de 'stille reserve'

$\begin{array}{lll}0 /+ & 0 /+ & 0 /+ \\ 0 & 0 & 0 \\ 0 /+ & 0 /+ & 0 /+ \\ + & + & + \\ 0 /+ & 0 /+ & 0 /+ \\ 0 & + & + \\ 0 & 0 & +\end{array}$

0: $\quad$ Oplossing van de werkgever heeft geen effect voor de doelgroep

+ +: Oplossing van de werkgever heeft mogelijk een positief effect voor de doelgroep

0/+: Oplossing van de werkgever heeft mogelijk een indirect effect voor de doelgroep Bron: ROA

\section{Aantrekken van baanwisselaars}

Zoals het schema aangeeft is het aantrekken van geschikt personeel uit de groep werkenden één van de mogelijkheden. De werkenden hebben in principe alleen maar voordelen voor werkgevers: ze hebben de juiste opleidingsachtergrond, willen werken en hebben werkervaring. Deze potentiële werknemers hebben daarom geen (of aanzienlijk minder) om- of bijscholing nodig en zijn dus relatief goedkoop en vooral snel inzetbaar. Ze dienen slechts te worden overgehaald van werkgever te wisselen. Hiertoe zal de werkgever zich aantrekkelijker moeten presenteren. De werkgever kan dit proberen te bereiken via hogere beloningen, betere secundaire arbeidsvoorwaarden of intensieve wervingscampagnes. Het op deze wijze aantrekken van reeds werkenden van andere bedrijven lost voor de individuele werkgever het personeelsprobleem weliswaar op, maar het is vanzelfsprekend geen oplossing voor de arbeidsmarkt als geheel: het bestaande knelpunt wordt uitsluitend verlegd.

Als de werkende van bedrijf verandert en hetzelfde beroep blijft uitoefenen is er voor de arbeidsmarkt als geheel niets veranderd, en heeft het knelpunt zich alleen verplaatst naar een andere werkgever. Als de baanwisselaar wel van beroep verandert, ontstaat er een vacature voor een ander beroep dan de oorspronkelijke vacature. Als de nieuwe vacature een beroep betreft waar de knelpunten minder groot zijn, kan hij snel worden vervuld vanuit het beschikbare en direct inzetbare aanbod. Op deze wijze zou het knelpunt arbeidsmarktbreed zijn opgelost. Een dergelijk proces is denkbaar als de baanwisselaar in een periode van overschotten toetrad tot de arbeidsmarkt, en hij een baan heeft geaccepteerd in een 'tweede keus'-beroep. Zodra er zich vervolgens de mogelijkheid aandient - in een krappe arbeidsmarkt - om over te stappen naar het 'eerste keus'-beroep dan zal er een kans zijn dat hij dat alsnog doet. Dergelijke baanwisselaars hebben waarschijnlijk niet meer dan een korte opfriscursus nodig om weer in hun 'eigenlijke'-beroep aan het 
werk te kunnen. Op deze manier zouden werkgevers relatief eenvoudig hun problemen opgelost hebben. Op het ogenblik lijkt het onderwijs een beroepssector waar men werknemers die met de juiste opleiding elders werkzaam zijn weer terug wil halen voor de klas.

\section{Scholing}

Het bij- en omscholen van eigen personeel is een andere mogelijkheid die werkgevers kunnen gebruiken om knelpunten op te lossen, dan wel vóór te zijn. Zodra er binnen een bedrijf vraag ontstaat naar een bepaald type opleiding dat op de arbeidsmarkt niet voorhanden is, kan een werkgever intern personeel voor die functie opleiden. Als dit mogelijk is, lost dit het knelpunt voor de oorspronkelijke vacature op. Maar ook nu ontstaat er in principe een nieuwe vacature op de plaats waar de werknemer eerst werkzaam was. Als deze nieuwe vacature relatief eenvoudig vervuld kan worden omdat er voor deze functie geen knelpunten op de arbeidsmarkt bestaan heeft de werkgever zijn personeelsprobleem opgelost. De werkgever heeft zijn probleem ook opgelost als de doorgroei van de werknemer naar een andere functie niet leidt tot een nieuwe vacature. Dit is denkbaar in situaties van grote veranderingen in het productieproces. In dat geval worden er op een plaats binnen het bedrijf mensen 'overbodig' terwijl er tegelijkertijd elders nieuwe vraag ontstaat. Ook in dat geval is scholing van eigen personeel waarschijnlijk de eenvoudigste manier om knelpunten op te lossen.

Het aantrekken van personeel met een andere of te lage opleidingsachtergrond is een andere aanpassing waar de werkgever voor kan kiezen. Deze, snel beschikbare, groep zal dan vervolgens alsnog intern geschoold of getraind dienen te worden, om hen geschikt te maken voor het beroep en de vaardigheden van het beroep waarin zich oorspronkelijk het knelpunt voordeed. Feitelijk is deze optie om knelpunten tegen te gaan echter niet meer dan een variant van de voorgaande alinea. Zouden we het om- of bijscholen van eigen personeel als 'interne scholing in de enge zin' kunnen definiëren, dan is het aantrekken van minder geschikt personeel om dit vervolgens binnen het bedrijf geschikt te maken, eigenlijk benoembaar als 'interne scholing in de ruime zin'.

Een nadeel van scholing dat het tegengaan van zowel als het anticiperen op verwachte knelpunten bemoeilijkt, is het simpele feit dat scholing tijd kost. Daarom zal het scholen van werkenden, werklozen of niet-participerenden zeker niet direct de voorkeur zal genieten van de werkgever. Voordat de effecten van scholing namelijk zichtbaar zijn, is er enige tijd verstreken. De knelpunten kunnen in die tijd (in het gunstigste geval) zijn verdwenen, maar het is ook alleszins voorstelbaar dat de problemen zich - bij gebrek aan adequate aanpak - hebben verergerd. Dus voordat een werkgever besluit zich te bedienen van om- en bijscholingstrajecten, zij het intern dan wel extern, om in zijn toekomstige personeelsbehoefte te voorzien, moet hij zich duidelijk voor ogen houden dat scholing in geen geval een 'instant solution' is. Elke vorm van scholing heeft een zekere 'effectiviteitstermijn', de periode die nodig is om de scholing uit te voeren en de effectiviteitstermijn van scholing is daarbij langer 
naarmate het verschil tussen de gewenste en de feitelijke opleidingsachtergrond groter is.

\section{Mobiliseren van de 'stille arbeidsreserve'}

De laatste strategie die een werkgever, die zich geconfronteerd ziet met knelpunten in de personeelsvoorziening, kan volgen is het rekruteren vanuit de (aanzienlijke) groep werklozen en niet-participerenden. Deze zogenaamde 'stille reserve' wordt opgemaakt door de moeilijk bemiddelbaren en de anderszins niet-actieven. Deze groep kenmerkt zich over het algemeen door een grote(re) afstand tot de arbeidsmarkt en wil men hen op een bruikbare wijze laten deelnemen aan het arbeidsproces dan zijn daar de nodige kosten aan verbonden. In deze aanbodgroep vinden we ook de uitgetreden vrouwen en ouderen terug, twee groepen die vanwege hun uitstroomgedrag mede debet zijn aan de lage participatiegraad die Nederland onderscheidt van veel andere Europese landen. Het stimuleren van de hernieuwde participatie van deze uittreders kan een aanzienlijke toename van werkzoekenden opleveren. De cruciale vraag hierbij is natuurlijk wel of dit aanbod 'geschikt' is. Het is vanzelfsprekend weinig zinvol je als werkgever te richten op niet-participerenden die een achtergrond hebben - zowel in opleiding als ervaring - die te ver afstaat van de eisen die je stelt aan een werknemer. De stille arbeidsreserve is vanuit het oogpunt van de werkgever echter niet homogeen: er zullen zich zowel geschikte als minder geschikte krachten in zitten. De voorkeur van een werkgever zal vanzelfsprekend uitgaan naar mensen die niet actief maar wél geschikt zijn. Ten slotte geldt dat hoe geschikter de kandidaat is, des te sneller en goedkoper hij inzetbaar is.

In deze paragraaf hebben we een aantal opties aangestipt die de werkgever kan implementeren. Zijn uiteindelijke keuze zal afhangen van (zijn inschatting van) de kosten die zijn verbonden aan het aantrekken van de specifieke groepen en de mogelijkheden die er op de arbeidsmarkt bestaan in zijn specifieke beroep. Logischerwijs is er geen optimale keuze aan te geven die voor elke werkgever toepasbaar is. Beroep- en sectoreigen aspecten van het rekruteringsprobleem en het al dan niet bestaan van uitwijkmogelijkheden en additioneel aanbod op lagere niveaus zullen ervoor zorgen dat elk probleem zijn eigen, niet-overdraagbare oplossing heeft. Het is dan ook moeilijk om op basis van het beschikbare datamateriaal aan te geven hoe groot de mogelijkheden voor werkgevers zijn. In eerder onderzoek door het ROA is getracht om aan te geven in hoeverre knelpunten opgelost kunnen worden door scholingsmaatregelen en het inzetten van niet-participerenden (zie Borghans e.a., 1998b, en De Grip e.a., 1999). De methode die in die studies gebruikt werd, was het bepalen van de knelpunten per opleiding̣stype om vervolgens van de nietparticiperende groepen op de arbeidsmarkt ia te gaan in hoeverre deze beschikken over de desbetreffende opleiding. Borghans e.a. hebben daarnaast ook indicatief bepaald hoeveel om- en bijscholing er maximaal plaats zou kunnen vinden om de tekorten op te lossen. Beide genoemde studies baseren zich echter op netto stromen. Het nadeel daarvan is dat heel moeilijk aan te geven is welke groepen met scholing benaderd zouden moeten worden om de rendementen zo hoog mogelijk te maken. 


\subsection{Samenvatting}

In het vorige hoofdstuk is een overzicht gegeven is van de arbeidsmarktmobiliteit die in de afgelopen jaren is opgetreden. Deze informatie kan gebruikt worden om een inschatting te maken van de mobiliteit die het komende jaar zal optreden. Op basis van deze verwachte mobiliteit zijn prognoses opgesteld voor de vraag- en aanbodontwikkelingen in het komende jaar. In dit hoofdstuk zijn daarvan de resultaten gepresenteerd.

De verwachte uitbreidingsvraag is gebaseerd op de groei van de werkgelegenheid per bedrijfssector zoals die door het CPB is gepubliceerd in het CEP. Hiervan kan een uitbreidingsvraag per beroepssector en per opleidingssector worden afgeleid. De totale uitbreidingsvraag is $1,7 \%$. Deze groei is uiteraard niet gelijk verdeeld over de beroepssectoren. De meeste sectoren groeien, maar de agrarische beroepen zullen in 2001 met een half procent krimpen. Die krimp van $0,5 \%$ is overigens minder dan de krimp in de bedrijfssector landbouw en visserij: een gedeelte van deze krimp doet zich dus voor bij 'niet-agrarische beroepen' binnen deze bedrijfssector. De informaticaberoepen en de sociaal-culturele beroepen kennen de grootste groei: deze twee sectoren zullen het komende jaar groeien met ongeveer $4 \%$. Vooral de groei van de informaticaberoepen laat zien dat de groei van de ICT-sector nog steeds niet aan zijn eind is, en dat deze beroepen nog steeds met een 'inhaalslag' bezig zijn ten opzichte van de overige beroepen. Ook tussen de opleidingssectoren zijn er verschillen in uitbreidingsvraag. Vanaf MBO-niveau is er sprake van een bovengemiddelde vraag, terwijl daaronder juist een lager dan gemiddelde vraag wordt verwacht. Het proces van upgrading speelt niet alleen op de middellange en lange termijn een rol, maar de effecten hiervan zijn ook op korte termijn zichtbaar.

In hoofdstuk 3 werd getoond dat er nog steeds mogelijkheden zijn voor niet- of laaggeschoolden. Het aantal werkenden met deze opleidingen neemt echter ieder jaar af. Het moet dus geconstateerd worden dat deze mogelijkheden uitsluitend bestaan door een relatief hoge vervangingsvraag. Blijkbaar verlaten meer laaggeschoolden de arbeidsmarkt dan nodig is om de gewenste reductie van het aantal laaggeschoolden te bewerkstelligen. Het gevolg daarvan is dat er nog steeds een vraag bestaat naar deze arbeidskrachten. Vanwege de afname van het aantal werkenden met deze opleiding zal de vervangingsvraag echter steeds kleiner worden, waardoor ook de totale vraag naar deze opleiding zal afnemen. Aan de andere kant is vanwege de toename van het gemiddelde opleidingsniveau de groep lager opgeleiden relatief oud. Hierdoor zal er de komende jaren een hogere vervangingsvraag ontstaan vanwege de vergrijzing. Het is op voorhand onduidelijk welke van de twee effecten op de vervangingsvraag het sterkste zal zijn, en wat dus het totale effect op de vraag is. Feit is wel dat door de dalende werkgelegenheid de mogelijkheden voor lager opgeleiden steeds minder worden. De relatief slechte perspectieven zullen dus zeker niet beter worden, maar de vraag is in welk tempo ze nog verder zullen verslechteren. Een andere verklaring voor de relatief hoge instroom van laagopgeleiden in het verleden wordt gevormd door de hoge vraag naar hoger opgeleiden. Voor deze hoger opgeleiden is echter al enige tijd sprake van een krappe arbeidsmarkt. Het zou kunnen zijn dat een deel van de geobserveerde vraag 
naar lager opgeleiden in feite 'substitutievraag' is, waarbij werkgevers de vacatures al dan niet met behulp van een cascadeconstructie - vervullen met lager opgeleiden dan dat zij eigenlijk hadden willen hebben. Wanneer dat het geval is, zal de vraag naar lager opgeleiden ook afnemen wanneer het aanbod van hoger opgeleiden (met name op het HBO-niveau) zal toenemen.

Naast de uitbreidingsvraag is er ook sprake van een aanzienlijke bruto vervangingsvraag. Ook hier zijn grote verschillen zichtbaar tussen de sectoren: zo kennen de al genoemde medische en paramedische beroepen een erg lage vervangingsvraag van nog geen $8 \%$, terwijl de verzorgende en dienstverlenende beroepen een erg hoge vervangingsvraag kennen van bijna $21 \%$. Dit verschil in vervangingsvraag wordt mede veroorzaakt door het verschil in opleidingsniveau tussen beide sectoren: bij de verzorgende en dienstverlenende beroepen is het opleidingsniveau veel lager, hetgeen resulteert in een veel hogere uitstroom. Ook de transportberoepen vallen op door een hoge vervangingsvraag. Ook deze hoge vervangingsvraag moet voor een groot deel aan het gemiddelde opleidingsniveau worden toegeschreven. Dit is des te opmerkelijker daar beide sectoren waar deze hoge uitstroom zich voordoet te maken hebben met vrij grote problemen om voldoende personeel te vinden. Misschien dat een (gedeeltelijke) oplossing gevonden kan worden in het 'zuiniger' omspringen met het eigen personeel. De vervangingsvraag per opleiding kent geen duidelijk patroon: er zijn geen duidelijke 'uitschieters', wel is het zo dat er een lichte tendens lijkt te bestaan dat de lagere opleidingsniveaus een relatief hoge uitstroom kennen, de middelbare niveaus een lage uitstroom, en de hogere niveaus weer een hogere uitstroom.

Tegenover de vraag staat het aanbod. Dat aanbod bestaat uit drie componenten. De eerste daarvan is het aanbod van baanwisselaars. Het blijkt dan dat een groot deel van de bruto vervangingsvraag geen echte arbeidsmarktuitstroom is: $13,4 \%$ van de werkenden stroomt uit, maar $6,5 \%$ van de werkenden is baanmobiel. De netto uitstroom is dus 'slechts' $6,9 \%$ van het aantal werkenden, aanzienlijk lager dan de bruto uitstroom maar nog steeds een hoog percentage. Uitstroom en baanmobiliteit zijn niet onafhankelijk van elkaar: de twee sectoren met de hoogste uitstroom kennen ook de hoogste instroom uit baanmobiliteit: zowel de transportberoepen als de verzorgende en dienstverlenende beroepen kennen een hoge instroom uit baanmobiliteit, een instroom van ca. $8 \%$ van het aantal werkenden. Aan de andere kant staan de openbare orde- en veiligheidsberoepen die een instroom uit baanmobiliteit kennen van slechts $1,7 \%$. Gepresenteerd naar opleidingssector valt op dat zowel de hoge als de lage opleidingsniveaus een relatief hoge baanmobiliteit kennen. Het verschil tussen uitstroom en baanmobiliteit is echter groter voor de lagere niveaus, hetgeen er op duidt dat van hen een veel groter deel werkloos wordt als men zijn baan verlaat. Ook dit duidt weer op een relatief zwakke positie van laagopgeleide werkenden.

Naast de baanwisselaars zijn er schoolverlaters als aanbieders op de arbeidsmarkt. De prognoses voor het aantal schoolverlaters zijn niet gebaseerd op het stromenmodel, maar op het instroommodel dat ook voor de arbeidsmarktprognoses voor de middellange termijn wordt gehanteerd. Binnen dit model wordt, op basis van de 
Referentieramingen van het Ministerie van Onderwijs, Cultuur en Wetenschappen, een prognose gemaakt van de aantallen schoolverlaters die per jaar de arbeidsmarkt betreden. Hierin worden ook de aantallen schoolverlaters uit het niet-initieel onderwijs meegeteld. Omdat deze voor een zeer groot deel al werkzaam zijn en hun opleiding naast hun werk afronden, zou dit in het model tot een dubbeltelling leiden. Daarom worden de gegevens over de herkomst van de schoolverlaters uit het nietinitieel onderwijs gebruikt om hiervoor te corrigeren.

De totale instroom van schoolverlaters in 2001 zal ongeveer $4,3 \%$ van het aantal werkenden bedragen. $\mathrm{Er}$ zijn duidelijke verschillen tussen de opleidingssectoren. $\mathrm{Er}$ wordt een relatief hoge instroom verwacht vanuit studie voor de drie economische opleidingssectoren VMBO economie, HBO economie en WO economie. En ook de algemene, voorbereidende opleidingen VMBO theorie en HAVONWO geven hoge instroom op de arbeidsmarkt te zien. $\mathrm{Er}$ is daarentegen relatief weinig instroom vanuit de agrarische en medische opleidingssectoren. Voor de agrarische opleidingssectoren geldt waarschijnlijk dat dit het gevolg is van een teruglopende interesse in de opleiding die mogelijk mede is gebaseerd op de verwachting dat de werkgelegenheid in de agrarische sector kleiner aan het worden is. Voor de medische sectoren betekent deze lage instroom dat de problemen die al enige tijd duren, op de korte termijn zeker niet minder zullen worden. Op basis van het stromenmodel kan een prognose gemaakt worden van de beroepssector waarin de schoolverlaters zich zullen aanbieden. De ene beroepssector blijkt een veel groter aanbod van schoolverlaters te kennen dan de andere. Zo worden in de transportberoepen een aantal schoolverlaters verwacht dat slechts $1,5 \%$ van het totaal aantal werkenden in de sector uitmaakt, terwijl dit in de openbare orde- en veiligheidsberoepen ongeveer $9 \%$ is. Blijkbaar zijn lang niet alle sectoren even populair bij de schoolverlaters, of zijn er in sommige sectoren nauwelijks mogelijkheden voor schoolverlaters. Deze mogelijkheden hangen namelijk ook in hoge mate samen met de vraag van werkgevers naar schoolverlaters. Vooral in beroepssectoren met een hoge mate van technologische vernieuwing zal de vraag naar schoolverlaters met nieuwe kennis groot zijn. Omdat schoolverlaters zich tot op zekere hoogte laten leiden door de verwachte vraag, zal dit leiden tot een relatief groot aanbod in deze beroepssectoren.

Enige zorg wekt het grote aantal schoolverlaters dat met uitsluitend Basisonderwijs de arbeidsmarkt zal betreden. Hoewel het in de data niet is na te gaan, is het merendeel van deze ongeschoolde schoolverlaters te wijten aan uitval in de lagere opleidingen. In een tijd waarin gesproken wordt over de startkwalificatie voor alle schoolverlaters, is het bedenkelijk dat het onderwijssysteem er blijkbaar niet in slaagt deze mensen aan een opleiding op VMBO-niveau te helpen. Te vrezen valt dat het aantal drop-outs alleen maar toe zal nemen als de druk toeneemt om een MBO- in plaats van een VMBO-opleiding te gaan volgen. In dat geval zal een actie om meer mensen aan een MBO-diploma te helpen wel eens averechts uit kunnen pakken, omdat het voor een deel van de scholieren 'te veel gevraagd is' en ze de school zullen verlaten voordat ze hun opleiding afgerond hebben.

De laatste aanbodcomponent wordt gevormd door de herintreders. In totaal is er een verwacht aanbod van $3,1 \%$ te zien. Er is één beroepssector die opvalt door een zeer 
groot aantal herintreders: de sector verzorgende en dienstverlenende beroepen. Hier wordt een aanbod van $6,4 \%$ verwacht. De overige sectoren kennen een aanbod van herintreders van ca. $2 \%$ van het aantal werkenden. Het onderscheid tussen de opleidingssectoren is groter. Het aanbod van herintreders concentreert zich daarbij vooral op de lagere opleidingsniveaus. Met name Basisonderwijs en VMBO economie kennen een groot aanbod van herintreders. Verder valt de hoge instroom voor VMBO verzorging en in mindere mate MBO dienstvertening en gezondheidszorg op. Het aantal herintreders op de hogere niveaus (zowel HBO als WO) is daarentegen laag.

Het aanbod van herintreders is lager dan het aanbod uit de baanwisselaars dat $6,5 \%$ bedraagt. Het is ook lager dan het aanbod van schoolverlaters dat $4,3 \%$ van het aantal werkenden bedraagt. Als dit vergeleken wordt met de verhoudingen die in hoofdstuk 3 gegeven werden over de historische instroom, dan kan geconcludeerd worden dat er een verschuiving aan het optreden is. Over de afgelopen jaren bestond bijna $60 \%$ van de instroom uit baanwisselaars, $20 \%$ uit schoolverlaters en $20 \%$ uit herintreders. In de prognoses lijkt de verhouding van het aanbod anders te liggen: in het aanbod is het belang van de schoolverlaters groter: in het aanbod wordt $47 \%$ gevormd door baanwisselaars, $31 \%$ door schoolverlaters, en $22 \%$ door herintreders.

Het confronteren van de vraag naar en het aanbod van arbeidskrachten levert een indicatie op van de spanning op de arbeidsmarkt. Het blijkt dat er in totaal een (klein) tekort aan arbeidskrachten is: nog afgezien van een eventuele kwalitatieve mismatch is de totale vraag groter dan het totale aanbod. Dit tekort aan arbeidskrachten doet zich in bijna alle beroepssectoren voor, maar er zijn verschillen. Aan de ene kant zijn er sectoren met een groot tekort zoals de transportberoepen en in mindere mate de verzorgende en dienstverlenende beroepen. In deze twee sectoren zal zich een relatief groot tekort voordoen wat tot (zeer) grote knelpunten in de personeelsvoorziening zal leiden voor de werkgevers. Het directe gevolg hiervan is dat deze sectoren voor werkzoekenden (zeer) goede kansen op werk bieden, mits men natuurlijk over de juiste kwalificaties beschikt. Aan de andere kant blijken er ook sectoren te zijn waar een evenwicht of zelfs een klein overschot aan werkenden verwacht wordt. In de technische en industrieberoepen zijn vraag en aanbod naar verwachting even groot, net zoals in de informaticaberoepen en de beroepssector openbare orde en veiligheid. Voor de medische en paramedische beroepen wordt zelfs een klein overschot verwacht! Achter dit overschot blijkt een kwalitatieve mismatch tussen vraag en aanbod schuil te gaan: het aanbod is wel van voldoende omvang maar van onvoldoende kwaliteit. Er lijkt dus sprake te zijn van een evenwicht maar toch kunnen werkgevers slecht weinig goed gekwalificeerd personeel vinden. Daarnaast kan deze contra-intuïtieve bevinding mogelijk verklaard worden uit een verschil tussen de geaggregeerde tekorten aan personeel en de feitelijke tekorten. Als er geaggregeerd sprake is van slechts een klein tekort, maar de arbeidskrachten een zeer hoge baanmobiliteit kennen heeft een gemiddelde werkgever heel vaak een vacature, ondanks het feit dat er over de hele sector gezien maar een zeer klein tekort is. Dit effect zal echter bij de medische beroepen slechts een kleine rol spelen, omdat daar juist sprake is van een relatief lage uitstroom. 
De grootste tekorten aan arbeidskrachten doen zich voor op het niveau van MBO en $\mathrm{HBO}$, de tekorten op WO-niveau daarentegen zijn relatief beperkt. Vooral MBO landbouw en techniek en MBO dienstverlening en gezondheidszorg kennen een relatief groot tekort aan arbeidskrachten. Hier blijkt dus dat er bij vraag en aanbod in de medische en paramedische beroepen sprake is van een kwalitatieve mismatch. $\mathrm{Er}$ mag dan binnen deze beroepssector geen tekort zijn, er is een zeer groot tekort aan mensen met een medische of paramedische opleiding. Ditzelfde geldt ook voor de technische opleidingen op MBO niveau. Dit suggereert dat hoewel het aantal mensen dat zich richt op de diverse beroepssectoren groot genoeg is, zij absoluut niet over de juiste kwalificaties beschikken. Deze kwalitatieve mismatch tussen vraag en aanbod per beroepsgroep maakt dat de cijfers per beroepsgroep met de nodige voorzichtigheid beschouwd moeten worden. Eigenlijk maakt dit duidelijk dat er per beroepsgroep een onderverdeling naar opleiding, en in ieder geval naar opleidingsniveau gemaakt zal moeten worden. Pas dan wordt duidelijk of het aanbod over de gevraagde kwalificaties beschikt. Dan pas is ook duidelijk wat voor de diverse sectoren de meest effectieve manier is om de knelpunten op te lossen.

De vraag is dan ook hoe werkgevers omgaan met knelpunten in de personeelsvoorziening. Er zijn een aantal mogelijkheden, maar elk van die mogelijkheden heeft zijn eigen voor- en nadelen. De afweging van de werkgever zal in hoge mate afhangen van de specifieke vacature en de mogelijkheden om hierin te voorzien. Hierbij speelt natuurlijk ook de vraag op welke termijn de vacature moet zijn vervuld een grote rol. Het zonder meer naar een bepaalde beroepssector leiden van mensen is uitsluitend zinvol als deze mensen over de juiste kwalificaties beschikken, of zodanig geschoold kunnen worden dat zij op korte termijn daar over kunnen beschikken. Dit vereist een zeer duidelijk inzicht in de combinatie van beroep en opleiding waar een knelpunt zich voordoet. Er is dus informatie nodig over de vraag aan welke opleidingen en vooral aan welke specifieke vaardigheden binnen de beroepssectoren behoefte is. Als deze informatie beschikbaar is, kan zeer gericht getraind en bemiddeld worden. Helaas is de huidige versie van het model nog niet in staat om deze gegevens op een betrouwbare manier te genereren. 


\section{Regionale ontwikkelingen op de arbeidsmarkt}

\subsection{Inleiding}

Voor een groot aantal doeleinden zijn landelijke prognoses niet toereikend. De meeste werkgevers werven hun personeel, zeker voor de lagere functies, op de regionale arbeidsmarkt. Zo zoeken ook veel mensen in hun eigen regio naar werk. Ook opereren organisaties als Arbeidsvoorziening in hoge mate regionaal, en hebben dus voor hun scholings- en bemiddelingsprogramma's arbeidsmarktgegevens nodig over hun eigen regio, om op basis daarvan tot adequaat beleid te kunnen komen. De landelijke prognoses geven dan ook niet de informatie waar deze gebruikers behoefte aan hebben. De landelijke cijfers geven namelijk niet aan of er sprake is van een regionale mismatch: ze laten niet zien of vraag en aanbod zich op dezelfde plaats bevinden. Het kan namelijk zo zijn dat er op landelijk niveau sprake is van een evenwicht, terwijl tegelijkertijd alle regio's te maken hebben met knelpunten. Een extreem voorbeeld zou kunnen zijn dat er in het noorden van het land 100 monteurs werk zoeken maar niet kunnen vinden, terwijl er in het zuiden werkgevers 100 vacatures hebben voor monteurs maar deze niet vervuld kunnen krijgen. In dat geval zullen landelijke cijfers aangeven dat er sprak is van een evenwicht: de vraag is tenslotte even groot als het aanbod. Om zo goed mogelijk bij de regionale indeling van Arbeidsvoorziening aan te sluiten wordt een regionale indeling gehanteerd zoals die in schema 5.1 vermeld staat.

Schema 5.1

De gehanteerde regio-indeling bij de regionale arbeidsmarktprognoses

\begin{tabular}{|c|c|c|}
\hline Regionaam & Afkorting & RBA-gebieden \\
\hline $\begin{array}{l}\text { Noord-Nederland } \\
\text { Oost-Nederland } \\
\text { Noordwest-Nederland } \\
\text { Middenwest-Nederland } \\
\text { Zuidwest-Nederland } \\
\text { Zuidoost-Nederland }\end{array}$ & $\begin{array}{l}\mathrm{N} \\
\mathrm{O} \\
\mathrm{NW} \\
\mathrm{MW} \\
\mathrm{ZW} \\
\mathrm{ZO}\end{array}$ & $\begin{array}{l}\text { Groningen, Friesland, Drenthe } \\
\text { Overijssel, IJssel-Veluwe, Gelderland } \\
\text { Flevoland, Noord-Holland Noord, Zuidelijk Noord-Holland } \\
\text { Midden-Nederland, Rijnstreek, Haaglanden } \\
\text { Rijnmond, Zeeland, Midden- en West-Brabant } \\
\text { Noordoost-Brabant, Zuidoost-Brabant, Limburg }\end{array}$ \\
\hline
\end{tabular}

Bron: Arbeidsvoorziening

Om aan de informatiebehoefte op regionaal niveau tegemoet te komen, wordt in dit hoofdstuk een overzicht gegeven van regionale arbeidsmarktprognoses. Hoewel de hier gepresenteerde cijfers voorzien in een informatiebehoefte, moet er een aantal relativerende kanttekeningen bij geplaatst worden. In de methodiek is een aantal keuzen gemaakt die tot gevolg hebben dat de regionale cijfers tenderen naar de landelijke cijfers. De verschillen tussen de regio's kunnen daarom worden onderschat. Aan de andere kant zijn er ook een paar keuzen gemaakt die juist tot gevolg hebben dat bestaande verschillen tussen regio's in stand blijven. Het gevolg daarvan is juist dat verschillen mogelijk overschat worden. Het 'netto effect' van deze voorspelfouten is nog niet bekend. Hiervoor, en om de betrouwbaarheidsmarges in te schatten, is eerst een evaluatie van de prognoses en de nu voor het eerst gebruikte methodiek nodig. 
Een laatste kanttekening is dat het aan te raden is om de regionale cijfers altijd in samenhang met de landelijke cijfers te bezien. Als er in een bepaalde regio een groot tekort is, maar in een aangrenzende regio een overschot, zou het niet juist zijn om in de regio waar een tekort is extra mensen op te gaan leiden terwijl ze in de aangrenzende regio geen werk kunnen vinden. Het bevorderen van regionale mobiliteit ligt dan veel meer voor de hand. Dit kan men echter alleen zien als men naast de cijfers van een regio ook de cijfers van de andere regio's en de landelijke cijfers in de vergelijking betrekt.

De opbouw van dit hoofdstuk is als volgt. In paragraaf 5.2 wordt ingegaan op de regionale verdeling van de werkgelegenheid. Vervolgens geeft paragraaf 5.3 de prognoses voor de uitbreidingsvraag en gaat paragraaf 5.4 in op de prognoses voor de bruto vervangingsvraag. De aanbodcijfers worden in paragraaf 5.5 gepresenteerd, waarna de regionale knelpunten op de arbeidsmarkt in paragraaf 5.6 gepresenteerd worden. Paragraaf 5.7 bevat tot slot de conclusies en enkele afsluitende opmerkingen.

\subsection{Werkgelegenheid per regio}

Voordat in de rest van dit hoofdstuk de regionale prognoses getoond worden, is het nuttig om te weten hoe de werkgelegenheid over de regio's verdeeld is. Dit maakt het beter mogelijk de percentages uit de volgende paragrafen te beoordelen. Wel is het zo dat - net zoals dit voor de landelijke prognoses het geval is - de cijfers over de werkgelegenheid betrekking hebben op het jaar 1998, terwijl de percentages bepaald zijn op basis van de verwachte aantallen werkenden in het jaar 2000.

Tabel 5.1 laat het aantal werkenden in de zes regio's en het landelijk totaal zien per beroepssector. De regio's zijn duidelijk verschillend van omvang: het aantal werkenden in Noord-Nederland is met 632 duizend aanmerkelijk kleiner dan de aantallen werkenden in de overige regio's. De grootste regio is Middenwest-Nederland, met 1,3 miljoen werkenden. Het blijkt dat in de meeste regio's de structuur van de werkgelegenheid die van het landelijk totaal volgt. Er zijn echter sectoren die in bepaalde regio's sterker vertegenwoordigd zijn dan in andere. Zo zijn de culturele beroepen relatief sterker vertegenwoordigd in Noordwest-Nederland, terwijl ze van minder belang zijn in Noord-Nederland. Daarentegen zijn de technische en industrieberoepen juist relatief minder sterk vertegenwoordigd in Noordwest- en MiddenwestNederland vergeleken met de andere regio's. De noordelijke regio's kennen een werkgelegenheidsstructuur waarin de landbouw en de techniek belangrijk zijn, de informaticaberoepen en de economisch-administratieve beroepen zijn daar juist relatief van minder belang. Deze verschillen tussen de regio's in zowel omvang als samenstelling van de beroepsbevolking zullen tot gevolg hebben dat ontwikkelingen niet in alle regio's hetzelfde effect zullen hebben. Overigens zijn niet alleen de verschillen tussen de regio's wat omvang van de diverse sectoren een grond voor verschillen. Het is ook mogelijk dat er binnen sectoren verschillen bestaan tussen de regio's. Als binnen een sector de ene regio een relatief oud of laag opgeleid personeelsbestand heeft, zal die sector in die regio een andere ontwikkeling laten zien dan 
diezelfde sector in de overige regio's. In dat geval zullen de ontwikkelingen op de regionale arbeidsmarkten verschillen als gevolg van regionale verschillen in de opleidingsachtergrond en leeftijd van de beroepsbevolking.

Tabel 5.1

Werkgelegenheid per beroepssector, naar regio in duizenden, 1998

\begin{tabular}{|c|c|c|c|c|c|c|c|}
\hline \multirow[b]{2}{*}{ Beroepssector } & \multicolumn{5}{|c|}{ Regio ${ }^{a)}$} & \multicolumn{2}{|r|}{ Totaal } \\
\hline & $\mathbf{N}$ & 0 & NW & MW & ZW & ZO & \\
\hline Pedagogische beroepen & 31,5 & 67,0 & 55,5 & 78,5 & 61,5 & 50,5 & 344,5 \\
\hline Culturele beroepen & 9,5 & 20,0 & 34,5 & 34,0 & 18,5 & 13,0 & 129,5 \\
\hline Agrarische beroepen & 38,5 & 62,5 & 34,5 & 47,0 & 43,0 & 42,5 & 268,0 \\
\hline Technische en industrieberoepen & 161,5 & 316,5 & 207,5 & 225,0 & 302,0 & 265,51 & $1.478,0$ \\
\hline Transportberoepen & 36,0 & 67,0 & 61,0 & 66,5 & 82,0 & 60,5 & 373,0 \\
\hline Medische en paramedische beroepen & 37,5 & 66,5 & 65,5 & 82,0 & 71,5 & 55,5 & 378,5 \\
\hline Economisch-administratieve beroepen & 151,0 & 309,5 & 340,5 & 442,5 & 350,5 & 272,51 & $1.866,0$ \\
\hline Informaticaberoepen & 12,0 & 29,5 & 41,5 & 56,5 & 30,0 & 25,5 & 194,5 \\
\hline Sociaal-culturele beroepen & 19,5 & 36,5 & 33,0 & 47,0 & 36,0 & 27,5 & 199,0 \\
\hline $\begin{array}{l}\text { Verzorgende en dienstverlenende } \\
\text { beroepen }\end{array}$ & 113,5 & 190,5 & 175,5 & 195,5 & 192,0 & 165,51 & $1.032,0$ \\
\hline Openbare orde- en veiligheidsberoepen & 9,5 & 17,0 & 23,0 & 19,0 & 22,5 & 15,0 & 106,0 \\
\hline Totaal & Ju, & 06 & 093, & 1.322, & 200, & 1.018 & 6.504 \\
\hline
\end{tabular}

a) De afkortingen verwijzen naar de naamgeving zoals die in schema 5.1 gegeven wordt Bron: CBS/ROA

In tabel 5.2 wordt de omvang en samenstelling van de beroepsbevolking in de regio's getoond naar opleidingssector. De verschillen tussen de regio's laten zich voor een groot deel afleiden uit de vorige tabel. Omdat in de noordelijke regio's landbouw en techniek relatief belangrijker zijn dan de dienstverlening en de economisch-administrative beroepen, zijn in die regio's de technische en agrarische opleidingen veel sterker vertegenwoordigd dan de opleidingen die gerelateerd zijn aan de dienstverlening. Deze verschillen hebben ook gevolgen voor het gemiddelde opleidingsniveau in de diverse regio's. In Noord-Nederland en in Zuidwest-Nederland is het aantal mensen dat een opleiding lager dan MBO heeft het grootste, terwijl in Noordwest- en Middenwest-Nederland het aantal hoogopgeleiden veel groter is dan in de rest van Nederland: in die twee regio's is ca. $11 \%$ van de werkenden op WO-niveau geschoold, terwijl dit landelijk gezien slechts $8 \%$ is. Dit is vooral te wijten aan het feit dat in Noord-Nederland nog geen $5 \%$ een WO-opleiding gevolg heeft. Ditzelfde verschil doet zich ook voor op het niveau van $\mathrm{HBO}$, maar de verschillen tussen de regio's zijn hier aanmerkelijk kleiner.

De verschillen in de structuur van de werkgelegenheid zullen waarschijnlijk niet alleen tot gevolg hebben dat de verwachte ontwikkelingen tussen de regio's verschillen. Ze zullen ook gevolgen hebben voor de werking van de arbeidsmarkt in de diverse regio's. Zo kan het feit dat er in Noord-Nederland relatief weinig werkgelegenheid is voor mensen met een WO-opleiding er toe leiden dat mensen met een dergelijke opleiding niet snel naar Noord-Nederland zullen verhuizen. Er is daar voor 
hen slechts een beperkt aantal werkgevers, hetgeen hun loopbaanperspectief daar negatief kan beïnvloeden. Een zelfde argument wordt voor de regio Zuidoost-Nederland ook wel gehoord, met name als het gaat om de opleidingssectoren $\mathrm{HBO}$-economie en WO-economie: vanwege het beperkte aantal werkgevers in die regio is het geen aantrekkelijke regio voor mensen met een dergelijke achtergrond. Het gevolg hiervan is dat werkgevers mogelijk moeite kunnen ondervinden bij het vinden van voldoende goed opgeleid personeel op dit niveau.

Tabel 5.2

Werkgelegenheid per opleidingssector, naar regio in duizenden, 1998

\begin{tabular}{|c|c|c|c|c|c|c|c|}
\hline \multirow[b]{2}{*}{ Opleidingssector } & \multicolumn{6}{|c|}{ Regio } & \multirow[t]{2}{*}{ Totaal } \\
\hline & $\mathrm{N}$ & 0 & NW & MW & ZW & ZO & \\
\hline Basisonderwijs & 45,5 & 87,0 & 75,5 & 90,5 & 106,0 & 76,0 & 480,0 \\
\hline VMBO theorie & 41,0 & 78,0 & 83,5 & 102,0 & 84,5 & 68,0 & 456,5 \\
\hline VMBO landbouw en techniek & 62,5 & 108,0 & 63,5 & 76,0 & 104,0 & 83,0 & 496,5 \\
\hline VMBO economie & 14,5 & 29,5 & 27,0 & 28,0 & 33,5 & 24,0 & 156,5 \\
\hline VMBO verzorging & 18,0 & 36,0 & 24,0 & 31,0 & 38,5 & 35,0 & 182,5 \\
\hline HAVONWO & 26,5 & 48,0 & 74,5 & 86,5 & 59,5 & 47,0 & 342,0 \\
\hline MBO landbouw en techniek & 116,5 & 216,5 & 155,5 & 160,5 & 210,0 & 175,0 & $1.034,0$ \\
\hline MBO economie & 79,0 & 153,5 & 118,5 & 149,5 & 147,0 & 120,0 & 767,0 \\
\hline \multicolumn{8}{|l|}{ MBO dienstverlening en } \\
\hline gezondheidszorg & 81,5 & 134,5 & 111,5 & 126,5 & 121,5 & 110,0 & 685,5 \\
\hline HBO landbouw en techniek & 22,0 & 46,5 & 45,0 & 62,5 & 48,0 & 44,0 & 268,0 \\
\hline HBO economie & 20,0 & 45,5 & 48,0 & 63,5 & 49,5 & 39,0 & 265,5 \\
\hline \multicolumn{8}{|l|}{ HBO onderwijs en sociaal- } \\
\hline HBO paramedisch & 9,5 & 21,0 & 17,0 & 23,5 & 20,0 & 17,0 & 108,0 \\
\hline WO landbouw en techniek & 6,0 & 21,5 & 22,0 & 45,5 & 17,5 & 20,5 & 133,5 \\
\hline WO economie & 7,5 & 19,0 & 35,5 & 47,0 & 31,5 & 20,0 & 160,5 \\
\hline \multicolumn{8}{|l|}{ WO letteren en sociaal- } \\
\hline cultureel & 11,0 & 23,0 & 41,5 & 50,5 & 18,5 & 15,0 & 159,0 \\
\hline WO medisch & 5,0 & 9,5 & 13,5 & 16,5 & 9,5 & 8,0 & 62,5 \\
\hline Totaal & 632,0 & $1.206,0$ & $1.093,0$ & $1.322,5$ & $1.233,0$ & $1.018,5$ & $6.504,5$ \\
\hline
\end{tabular}

Bron: CBS/ROA

Daarnaast valt het te verwachten dat verschillen in werkgelegenheid tussen regio's ook de mate van mobiliteit beïnvloeden: meer mogelijkheden tot mobiliteit leiden doorgaans ook tot meer mobiliteit. Het is dus maar de vraag of mobiliteit van werkenden uitsluitend afhangt van hun eigen kenmerken, en niet ook voor een deel bepaald wordt door de sociale en economische verschillen tussen de regio's. In de volgende paragrafen gaan we er echter wel van uit dat de mobiliteit uitsluitend afhangt van de persoonlijke kenmerken. Nader onderzoek naar regionale verschillen in arbeidsmarktgedrag en de mogelijkheden om deze verschillen in het gebruikte stromenmodel op te nemen moet in de toekomst zeker verricht worden. 


\subsection{Uitbreidingsvraag per regio}

In hoofdstuk 4 is in tabel 4.1 aangegeven wat landelijk gezien de sectorale groei van de werkgelegenheid zal zijn in 2001. Op basis van de regionale prognoses van Arbeidsvoorziening (Arbeidsvoorziening, 2000) kan deze groei ook voor de zes afzonderlijke regio's bepaald worden. In tabel 5.3 staat de regionale groei per sector weergegeven, met in de laatste kolom nogmaals de landelijke groeipercentages.

Tabel 5.3

Procentuele groei per bedrijfssector voor de verschillende regio's, 2001

\begin{tabular}{lrrrrrrrr}
\hline & & \multicolumn{3}{c}{ Regio } & & & $\begin{array}{r}\text { Landelijk } \\
\text { totaal }\end{array}$ \\
Bedrijfssector & N & O & NW & MW & ZW & ZO & \\
\hline & & & & & & & \\
\hline Landbouw en visserij & $-1,5$ & $-1,5$ & $-0,6$ & $-0,6$ & $-1,1$ & $-1,2$ & $-1,1$ \\
Voeding & $-0,0$ & 0,8 & 0,4 & 0,0 & 0,6 & 1,0 & 0,5 \\
Chemie & 0,5 & 1,3 & 0,8 & 0,9 & 0,9 & 1,6 & 1,1 \\
Metaal en elektrotechniek & 1,0 & 1,4 & 0,8 & 1,0 & 1,2 & 1,5 & 1,2 \\
Overige industrie & 0,3 & 1,0 & 0,2 & 0,3 & 0,7 & 0,9 & 0,7 \\
Energie & 0,8 & 0,1 & 0,1 & $-0,1$ & $-1,0$ & 0,3 & $-0,1$ \\
Bouw en onroerend goed & 0,3 & 1,0 & 0,5 & 0,3 & 0,8 & 1,0 & 0,7 \\
Handel en reparatie & 2,3 & 2,9 & 3,0 & 2,8 & 3,2 & 2,9 & 2,9 \\
Transport en communicatie & 2,1 & 2,9 & 3,0 & 2,4 & 2,5 & 2,7 & 2,7 \\
Bank- en verzekeringswezen & 0,9 & 1,8 & 1,7 & 1,6 & 1,7 & 1,9 & 1,7 \\
Horeca en zakelijke dienstverlening & 3,0 & 4,0 & 3,0 & 3,0 & 3,5 & 3,8 & 3,3 \\
Kwartaire diensten & 2,5 & 2,8 & 3,0 & 2,5 & 2,8 & 3,0 & 2,8 \\
Overheid en onderwijs & 0,3 & 0,6 & 0,6 & $-0,0$ & 0,5 & 0,8 & 0,4 \\
Total & 1,2 & 1,8 & 1,9 & 1,6 & 1,8 & 1,9 & 1,7 \\
\hline Bron: CPB/Arbeidsvoorziening/ROA & & & & & & & &
\end{tabular}

In de laatste regel van de tabel is te zien dat er relatief weinig verschillen in uitbreidingsvraag tussen de regio's zijn. Alleen Noord-Nederland blijft duidelijk achter in groei. Als echter de sectoren afzonderlijk bekeken worden valt op dat er toch wel sprake is van grotere verschillen. Hoewel voor de meeste sectoren er in alle regio's sprake is van ofwel groei ofwel krimp (landbouw), valt de bedrijfssector energie op omdat hier sprake lijkt te zijn van een verschuiving van de werkgelegenheid zonder dat daar een landelijke groei of krimp mee gepaard gaat. In Noord-Nederland groeit deze bedrijfssector met bijna $1 \%$ terwijl in Zuidwest-Nederland er een krimp van $1 \%$ is. Maar ook de sectoren waarvoor de trend in alle regio's gelijk is kennen nog verschillen. Zo is bijvoorbeeld de werkgelegenheidsgroei in de sector landbouw en visserij naar verwachting minder ongunstig in Noordwest-Nederland en MiddenwestNederland. In Oost-Nederland groeit de bedrijfssector horeca en zakelijke dienstverlening met $4 \%$ sterker dan het landelijk gemiddelde dat op 3,3\% ligt. De over het algemeen kleine verschillen in de groeicijfers per regio, zijn indicatief voor het feit dat de werkgelegenheid(-sgroei) zich voor geen enkele beroepssector zal beperken tot één bepaald landsdeel. Hoewel niet in alle regio's dezelfde bedrijfssector verantwoordelijk is voor de groei kan er van een evenredig verdeelde landelijke groei gesproken worden. De enige regio enigszins achterblijt is Noord-Nederland, maar het simpele feit dat er hier minder groei wordt verwacht, wil natuurlijk niet zeggen dat 
dit problemen gaat opleveren. Een achterblijvende economische ontwikkeling is alleen maar dan problematisch als er op hetzelfde moment aan de aanbodzijde teveel werkzoekenden zijn. Dit komt in paragraaf 5.5 nader aan de orde.

Op basis van deze sectorale groeiverwachtingen per regio de uitbreidingsvraag per beroep en opleiding afgeleid worden op basis van het door het ROA ontwikkelde opleidings- en beroepenmodel. Hiervoor wordt hetzelfde model gebruikt dat ook voor de landelijke prognoses gehanteerd is. Hiervoor moet dan wel de veronderstelling gemaakt worden dat upgrading en verschuivingen in de beroepenverdeling binnen sectoren in alle regio's in gelijke mate optreden. In tabel 5.4 staat de uitbreidingsvraag per beroepssector zoals die op basis van het beroepenmodel bepaald is. Omdat het weinig zinvol is om per regio de aantallen te vergelijken zonder daarbij ook de omvang van de beroepsbevolking te betrekken, worden in deze tabel uitsluitend de procentuele groeiverwachtingen getoond. In de laatste kolom van de tabel staat weer het landelijke totaal genoemd. Zoals eerder in hoofdstuk 2 is aangegeven zijn de typeringen voor de regionale prognoses per regio bepaald. Dit maakt het onmogelijk deze typeringen tussen de regio's te vergelijken: ook de typeringen worden daarom niet in de tabel vermeld ${ }^{17}$. In de Statistische Bijlage kunnen per regio ook de aantallen en typeringen gevonden worden.

Tabel 5.4

Procentuele uitbreidingsvraag per beroepssector naar regio, 2001

\begin{tabular}{|c|c|c|c|c|c|c|c|}
\hline \multirow{2}{*}{ Beroepssector } & \multicolumn{5}{|c|}{ Regio } & \multicolumn{2}{|c|}{ Totaal } \\
\hline & $\mathrm{N}$ & 0 & NW & MW & ZW & ZO & \\
\hline Pedagogische beroepen & 0,5 & 0,7 & 0,8 & 0,1 & 0,7 & 0,9 & 0,6 \\
\hline Culturele beroepen & 2,3 & 2,0 & 1,2 & 1,4 & 2,4 & 3,7 & 1,9 \\
\hline Agrarische beroepen & $-1,1$ & $-0,8$ & 0,0 & $-0,3$ & $-0,5$ & $-0,5$ & $-0,5$ \\
\hline Technische en industrieberoepen & $-0,3$ & 0,3 & 0,1 & 0,0 & 0,2 & 0,3 & 0,2 \\
\hline Transportberoepen & 1,7 & 2,4 & 2,8 & 2,4 & 2,3 & 2,4 & 2,4 \\
\hline Medische en paramedische beroepen & 1,6 & 1,9 & 2,0 & 1,5 & 1,8 & 2,0 & 1,8 \\
\hline Economisch-administratieve beroepen & 2,3 & 3,0 & 2,7 & 2,2 & 2,8 & 3,1 & 2,7 \\
\hline Informaticaberoepen & 4,4 & 4,1 & 3,3 & 2,6 & 4,6 & 4,7 & 3,7 \\
\hline Sociaal-culturele beroepen & 4,8 & 3,7 & 4,0 & 4,6 & 3,6 & 3,9 & 4,0 \\
\hline Verzorgende en dienstverlenende beroepen & 1,6 & 2,4 & 2,4 & 2,4 & 2,4 & 2,4 & 2,3 \\
\hline Openbare orde- en veiligheidsberoepen & 0,5 & 0,9 & 0,7 & 0,2 & 0,7 & 1,2 & 0,7 \\
\hline Totaal & 1,2 & 1,8 & 1,9 & 1,6 & 1,8 & 1,9 & 1,7 \\
\hline
\end{tabular}

Bron: ROA

17. Bij de landelijke prognoses is er ook nog een verbijzondering gemaakt naar de afzonderlijke beroepen en opleidingen. De resultaten daarvan staan niet in dit rapport, maar wel in de bijbehorende Statistische Bijlage vermeld. Vanwege het lage regionale aggregatieniveau was het niet mogelijk om tot een betrouwbare verbijzondering binnen de beroeps- en opleidingssectoren te komen. De regionale prognoses worden zowel in het rapport als de Statistische Bijlage derhalve uitsluitend op dit hogere aggregatieniveau gepresenteerd. 
Zoals op basis van de werkgelegenheidsontwikkeling per bedrijfssector te verwachten valt, kennen de diverse beroepssectoren verschillen tussen de regio's en tussen de sectoren binnen de regio's. De verschillen tussen regio's per beroepssector lijken groter dan de verschillen per bedrijfssector. Dit wordt veroorzaakt door het feit dat naast de verschuivingen in werkgelegenheid tussen de bedrijfssectoren er nu ook sprake is van verschuivingen tussen beroepen. Landelijk gezien kent alleen de sector agrarische beroepen een krimpende werkgelegenheid. Met deze krimp worden alle regio's geconfronteerd met uitzondering van Noordwest-Nederland waar de werkgelegenheid in deze sector gelijk blijft. Ook beroepssectoren die landelijk gezien groeien doen dat niet in alle regio's even sterk. Zo kennen de technische en industrieberoepen landelijk gezien een kleine groei, maar in Noord-Nederland een kleine krimp. Het ontbreken van grote bevolkingscentra en een hogere vergrijzing dan landelijk leidt er verder toe dat ook de groei met name voor de twee dienstensectoren economisch-administratieve beroepen en verzorgende en dienstverlenende beroepen in Noord-Nederland beneden het landelijke cijfer blijft. Ook is het niet zo dat in alle regio's dezelfde sector de grootste groeier is: Zo zijn de informaticaberoepen in een drietal regio's (Oost-Nederland, Zuidwest-Nederland en ZuidoostNederland) de grootste groeier, terwijl landelijk gezien de sociaal-culturele beroepen de grootste groei doormaken. Ook blijkt dat niet voor alle sectoren dezelfde regio de grootste groei doormaakt: zo groeien de sociaal-culturele beroepen het hardst in Noord-Nederland terwijl de algehele werkgelegenheidsgroei in deze regio achterblijft bij de rest van Nederland. Toch lijkt de algemene conclusie gerechtvaardigd dat de verschillen tussen de sectoren in de diverse regio's het algemene beeld volgen dat in de onderste regel van de tabel te vinden is. Ook de verschillen tussen de sectoren in de regio's volgen het algemene beeld dat in de laatste kolom van de tabel vermeld staat.

De regionale verschillen in uitbreidingsvraag kunnen ook per opleidingssector bepaald worden. Deze cijfers zijn te vinden in tabel 5.5. Ook hier geldt weer dat op het eerste gezicht de ontwikkelingen binnen de diverse regio's een afspiegeling zijn van wat er zich op landelijk niveau afspeelt. Daar waar de regionale prognoses voor de uitbreidingsvraag per beroepssector nog duidelijke afwijkingen van het landelijke patroon laten zien, lijkt dat hier veel minder het geval te zijn. In alle regio's wordt de sector Basisondenwijs geconfronteerd met de grootste krimp, gevolg door het VBMO met een kleine krimp in de werkgelegenheid (met uitzondering van VMBO theorie dat zelfs in alle regio's een bescheiden groei kent). De grootste groei in de werkgelegenheid wordt verwacht in de sector WO economie (Noord-Nederland, Oost-Nederland, Zuidwest-Nederland en Zuidoost-Nederland) of de sector HBO paramedisch (Noordwest-Nederland en Middenwest-Nederland).

Toch doen zich ook in tabel 5.5 een aantal afwijkingen van het algemene patroon voor. Niet alle afzonderlijke sectoren volgen het landelijke beeld: zo groeit de sector WO economie zeer sterk in Noord- en in Oost-Nederland, met een percentage dat bijna twee keer het landelijk gemiddelde bedraagt, terwijl de totale groei in NoordNederland achterblijft bij de groei in de rest van Nederland. De verdeling van de groei van deze sector lijkt er op te duiden dat er een inhaalslag aan het plaatsvinden is in de verder van de Randstad gelegen gebieden. Opvallend is ook dat de sector WO 
landbouw en techniek in Noord-Nederland een zeer sterke groei laat zien (sterker dan in de andere regio's), terwijl zowel de beroepssector van de agrarische als de technische en industrieberoepen in die regio een krimp vertoont. Deze krimp is ook terug te zien in de opleidingssector landbouw en techniek die op vrijwel alle niveaus een kleinere groei of een grotere krimp kent in Noord-Nederland. De enige uitzondering daarop vormt dus de sector WO landbouw en techniek. Blijkbaar vindt er in deze sectoren in Noord-Nederland een duidelijke upgrading plaats waarbij bij een krimpende werkgelegenheid ook nog de lager opgeleiden vervangen worden door hoger opgeleiden ${ }^{18}$.

Tabel 5.5

Procentuele uitbreidingsvraag per opleidingssector naar regio, 2001

\begin{tabular}{|c|c|c|c|c|c|c|c|}
\hline \multirow[t]{2}{*}{ Opleidingssector } & \multicolumn{5}{|c|}{ Regio } & \multicolumn{2}{|c|}{ Totaal } \\
\hline & $N$ & 0 & NW & MW & ZW & ZO & \\
\hline $\begin{array}{l}\text { Basisonderwijs } \\
\text { VMBO theorie } \\
\text { VMBO landbouw en techniek } \\
\text { VMBO economie } \\
\text { VMBO verzorging } \\
\text { HAVONWO } \\
\text { MBO landbouw en techniek } \\
\text { MBO economie } \\
\text { MBO dienstverlening en gezondheidszorg } \\
\text { HBO landbouw en techniek } \\
\text { HBO economie } \\
\text { HBO onderwijs en sociaal-cultureel } \\
\text { HBO paramedisch } \\
\text { WO landbouw en techniek } \\
\text { WO economie } \\
\text { WO letteren en sociaal-cultureel } \\
\text { WO medisch }\end{array}$ & $\begin{array}{r}-4,2 \\
0,5 \\
-1,4 \\
-2,4 \\
-0,5 \\
4,2 \\
1,6 \\
1,4 \\
1,8 \\
2,3 \\
4,0 \\
2,0 \\
4,3 \\
6,3 \\
7,6 \\
3,3 \\
3,2\end{array}$ & $\begin{array}{r}-3,6 \\
1,2 \\
-0,9 \\
-1,9 \\
0,1 \\
5,2 \\
2,3 \\
2,1 \\
2,5 \\
2,7 \\
4,2 \\
2,4 \\
4,2 \\
3,8 \\
6,9 \\
3,4 \\
3,7\end{array}$ & $\begin{array}{r}-3,5 \\
1,0 \\
-0,8 \\
-2,0 \\
0,2 \\
3,2 \\
2,5 \\
2,4 \\
3,0 \\
2,8 \\
3,9 \\
2,2 \\
4,2 \\
3,0 \\
3,7 \\
2,1 \\
2,3\end{array}$ & $\begin{array}{r}-3,7 \\
0,7 \\
-1,1 \\
-2,4 \\
-0,1 \\
3,1 \\
2,5 \\
2,1 \\
2,8 \\
2,3 \\
3,1 \\
1,8 \\
3,8 \\
1,5 \\
3,2 \\
1,8 \\
2,0\end{array}$ & $\begin{array}{r}-3,0 \\
1,1 \\
-0,8 \\
-1,8 \\
0,2 \\
4,2 \\
2,2 \\
2,2 \\
2,8 \\
2,7 \\
4,2 \\
2,4 \\
4,3 \\
4,4 \\
4,5 \\
4,2 \\
3,6\end{array}$ & $\begin{array}{r}-3,4 \\
1,3 \\
-0,8 \\
-1,9 \\
0,3 \\
4,7 \\
2,4 \\
2,3 \\
2,6 \\
2,5 \\
4,3 \\
2,6 \\
4,1 \\
3,6 \\
5,8 \\
4,4 \\
3,6\end{array}$ & $\begin{array}{r}-3,5 \\
1,0 \\
-1,5 \\
-2,4 \\
0,2 \\
3,9 \\
2,2 \\
2,3 \\
2,3 \\
2,0 \\
3,4 \\
1,9 \\
4,3 \\
2,8 \\
4,3 \\
3,7 \\
1,6\end{array}$ \\
\hline Totaal & 1,2 & 1,8 & 1,9 & 1,6 & 1,8 & 1,9 & 1,7 \\
\hline
\end{tabular}

Bron: ROA

De opleidingssector VMBO verzorging lijkt als enige geconfronteerd te worden met een regionale 'herverdeling'. De landelijke groei is beperkt (slechts $0,2 \%$ ), en deze komt tot stand doordat er in een tweetal regio's (Noord-Nederland en MiddenwestNederland) sprake is van een krimpende werkgelegenheid, en in de overige vier regio's van een licht groeiende werkgelegenheid.

In tabel 5.5 is te zien dat voor een aantal van de kleinere opleidingssectoren de regionale cijfers niet in overeenstemming zijn met de landelijke cijfers. Om precies te zijn, de optelsom van de regionale uitbreidingsvraag geeft een landelijke uitbreidingsvraag die hoger is dan de uitbreidingsvraag die op landelijke niveau bepaald is. Zoals

18. Hierbij moet wel bedacht worden dat het hier bij de hoger opgeleiden om zeer kleine aantallen gaat, waarbij deze ook nog iets te hoog worden ingeschat als gevolg van de verdeelmethodiek (zie hiervoor ook paragraaf 2.4 die handelt over deze methodiek). 
in hoofdstuk 2 is uitgelegd is dat een gevolg van de afrondfouten die optreden bij het verbijzonderen van de opleidingsindeling die in het rekenmodel gebruikt wordt naar de indeling zoals die in de tabellen gehanteerd wordt. Omdat deze afrondfout zich met name voordoet bij de kleinere opleidingssectoren, is hier ook sprake van grote afwijkingen in de berekende percentages. Omdat de afrondfout zich echter wel in alle regio's in vergelijkbare mate voordoet, geeft de tabel ook voor de kleinere opleidingssectoren de juiste verhoudingen tussen de regio's weer.

\subsection{Bruto vervangingsvraag per regio}

De tweede component van de vraag is de bruto vervangingsvraag. Bij de landelijke cijfers was al aangegeven dat deze bruto vervangingsvraag (de totale uitstroom) een veel groter deel van de vraag vormt dan de uitbreidingsvraag. De uitstroom hangt af van zowel de beroepssector waarin iemand werkt als de opleiding die hij gevolgd heeft. Dat maakt dat de bruto vervangingsvraag verschilt per beroepssector of per opleiding. Als er regionale verschillen zijn in de opleidingstructuur van de beroepssectoren, of juist in de beroepsverdeling binnen de opleidingssectoren, kunnen deze verschillen een oorzaak zijn van regionale verschillen in de vervangingsvraag. Daarnaast hangt de uitstroom ook samen met de leeftijd en het geslacht van een werknemer. Deze afhankelijkheid van persoonlijke kenmerken is daarom ook een bron van regionale verschillen in de vervangingsvraag. Als bepaalde regio's meer dan anderen te maken hebben met een vergrijzend personeelsbestand, zullen in die regio's de uitstroomcijfers veel hoger zijn dan het landelijk gemiddelde.

Tabel 5.6

Procentuele bruto vervangingsvraag per beroepssector naar regio, 2001

\begin{tabular}{|c|c|c|c|c|c|c|c|}
\hline \multirow[t]{2}{*}{ Beroepssector } & \multicolumn{6}{|c|}{ Regio } & \multirow[t]{2}{*}{ Totaal } \\
\hline & $\mathrm{N}$ & 0 & NW & MW & $Z W$ & ZO & \\
\hline Pedagogische beroepen & 9,4 & 9,3 & 9,5 & 9,5 & 9,6 & 9,1 & 9,4 \\
\hline Culturele beroepen & 12,7 & 12,5 & 12,3 & 12,8 & 13,0 & 12,1 & 12,7 \\
\hline Agrarische beroepen & 13,2 & 12,9 & 13,6 & 13,9 & 15,2 & 14,1 & 13,7 \\
\hline Technische en industrieberoepen & 12,4 & 12,4 & 12,4 & 12,3 & 12,2 & 12,1 & 12,3 \\
\hline Transportberoepen & 16,0 & 15,5 & 16,6 & 16,3 & 15,4 & 15,1 & 15,7 \\
\hline Medische en paramedische beroepen & 8,0 & 8,0 & 7,9 & 7,9 & 8,0 & 7,8 & 7,9 \\
\hline Economisch-administratieve beroepen & 12,2 & 12,1 & 12,2 & 12,1 & 12,1 & 12,0 & 12,1 \\
\hline Informaticaberoepen & 11,4 & 11,3 & 12,1 & 11,1 & 11,4 & 11,7 & 11,5 \\
\hline Sociaal-culturele beroepen & 13,1 & 12,8 & 12,7 & 11,6 & 12,5 & 13,1 & 12,5 \\
\hline Verzorgende en dienstverlenende beroepen & 20,6 & 20,8 & 20,9 & 20,9 & 21,0 & 20,7 & 20,9 \\
\hline Openbare orde- en veiligheidsberoepen & 10,4 & 9,5 & 10,2 & 9,9 & 9,9 & 9,8 & 10,0 \\
\hline Totaal & 13,7 & 13,4 & 13,5 & 13,2 & 13,4 & 13,4 & 13,4 \\
\hline
\end{tabular}

Bron: ROA

Gebaseerd op de landelijk geschatte relaties tussen persoonlijke kenmerken en de uitstroom kan voor de diverse regio's de bruto vervangingsvraag bepaald worden. In tabel 5.6 wordt de procentuele vervangingsvraag gepresenteerd voor de zes regio's. Uit deze tabel blijkt dat de verschillen tussen de regio's erg klein zijn. Eigenlijk zijn er 
maar twee regio's die afwijken: Noord-Nederland, met een iets hoger dan gemiddelde vervangingsvraag, en Middenwest-Nederland, met een iets lagere vervangingsvraag. Ook hier geldt weer dat niet alle sectoren in dezelfde regio de hoogste of juist de laagste vervangingsvraag kennen. Zo springt Zuidwest-Nederland er uit voor de agrarische beroepen die een veel hogere vervangingsvaag kennen (ruim 15\%). $\mathrm{Bij}$ de transportberoepen daarentegen is het Noordwest-Nederland die de grootste vervangingsvraag kent (met $16,6 \%$ bijna een vol procentpunt boven het landelijk gemiddelde). Voor een aantal andere beroepssectoren zijn de regionale verschillen echter heel klein: er zijn bijna geen regionale verschillen in de medische en paramedische beroepen, en ook in de verzorgende en dienstverlenende beroepen zijn geen regionale verschillen aan te duiden. Opvallend is wel dat Noord-Nederland, die in totaal de hoogste vervangingsvraag kent, voor vrijwel geen enkele sector een duidelijk hogere vraag kent dan in de andere regio's.

Er zijn ook regionale verschillen zichtbaar in de vervangingsvraag naar opleidingssector. Er zijn sectoren waarbij er weinig regionale verschillen zijn: de sector Basisonderwijs kent een kleine spreiding, net zoals de sectoren MBO landbouw en techniek en MBO landbouw en techniek. Dit is opvallend omdat juist de agrarische beroepen wel relatief grote verschillen tussen de regio's lieten zien.

Tabel 5.7

Procentuele bruto vervangingsvraag per opleidingssector naar regio, 2001

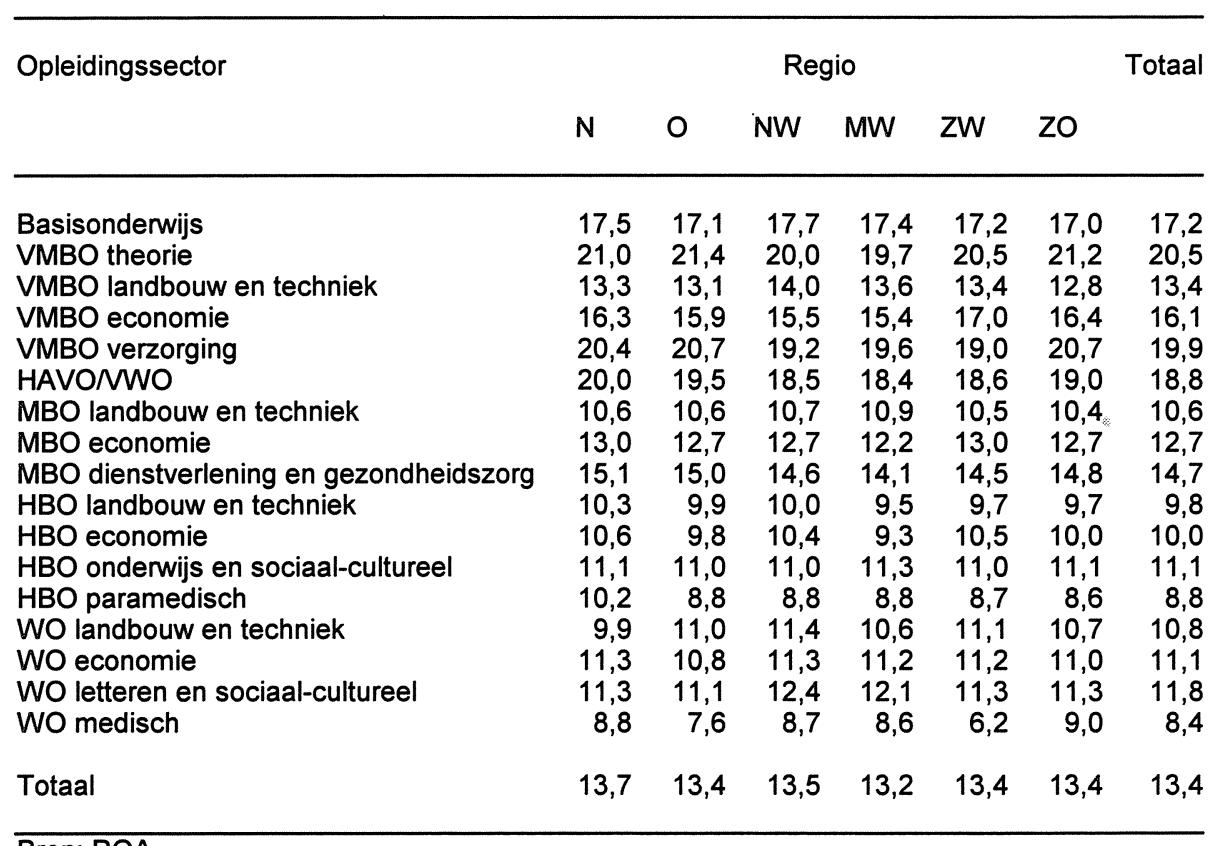

Bron: ROA

Daarentegen zijn er ook sectoren met relatief grote regionale verschillen: VMBO economie kent een vervangingsvraag van $17,0 \%$ in Zuidwest-Nederland, en $15,4 \%$ in Middenwest-Nederland. Opvallend is ook de relatief hoge vervangingsvraag van HBO paramedisch in Noord-Nederland. Dit is eigenlijk de enige 'medische' opleiding 
die grote regionale verschillen laat zien. Blijkbaar is er in Noord-Nederland sprake van een leeftijdsopbouw die een hoge uitstroom tot gevolg zal hebben. Ook de sector WO medisch kent grote verschillen, met een spreiding van $6,2 \%$ in ZuidwestNederland tot $9,0 \%$ in Zuidoost-Nederland. Ook voor deze opleidingssectoren geldt dat de 'bijbehorende' beroepssectoren juist geen grote regionale verschillen kennen. Blijkbaar worden deze verschillen dus in grote mate veroorzaakt door medische geschoolden die buiten de medische beroepen werkzaam zijn, terwijl de verschillen tussen de sectoren verminderd worden door niet-medisch geschoolden die werkzaam zijn in de medische beroepen. Hier blijkt dus ook uit dat voor een exacte analyse wat er nu 'precies' aan de hand is, de cijfers op ofwel beroeps- ofwel opleidingssector niet gedetailleerd genoeg zijn. Voor een beter beeld zijn cijfers per opleidingssector per beroepssector nodig. De data staan het betrouwbaar verkrijgen van dergelijke gedetailleerdere regionale informatie helaas niet toe.

\subsection{Totale vraag per regio}

De totale vraag per regio kan afgeleid worden uit de optelsom van de uitbreidingsvraag en de bruto vervangingsvraag. De resultaten daarvan staan vermeld in tabel 5.8 voor de totale vraag per beroepssector en in tabel 5.9 voor de totale vraag per opleidingssector. Er valt weinig toe te voegen aan datgene wat al over de afzonderlijke vraagcomponenten is gezegd.

Tabel 5.8

Procentuele totale vraag per beroepssector naar regio, 2001

\begin{tabular}{|c|c|c|c|c|c|c|c|}
\hline \multirow[t]{2}{*}{ Beroepssector } & \multicolumn{6}{|c|}{ Regio } & \multirow[t]{2}{*}{ Totaal } \\
\hline & $\mathrm{N}$ & 0 & NW & MW & $\mathrm{ZW}$ & $\mathrm{ZO}$ & \\
\hline $\begin{array}{l}\text { Pedagogische beroepen } \\
\text { Culturele beroepen } \\
\text { Agrarische beroepen } \\
\text { Technische en industrieberoepen } \\
\text { Transportberoepen } \\
\text { Medische en paramedische beroepen } \\
\text { Economisch-administratieve beroepen } \\
\text { Informaticaberoepen } \\
\text { Sociaal-culturele beroepen } \\
\text { Verzorgende en dienstverlenende beroepen } \\
\text { Openbare orde- en veiligheidsberoepen }\end{array}$ & $\begin{array}{r}9,9 \\
15,0 \\
12,1 \\
12,1 \\
17,7 \\
9,6 \\
14,5 \\
15,8 \\
17,9 \\
22,2 \\
11,0\end{array}$ & $\begin{array}{r}10,0 \\
14,5 \\
12,1 \\
12,7 \\
18,0 \\
9,9 \\
15,1 \\
15,4 \\
16,5 \\
23,2 \\
10,5\end{array}$ & $\begin{array}{r}10,3 \\
13,4 \\
13,6 \\
12,6 \\
19,5 \\
9,9 \\
14,9 \\
15,4 \\
16,7 \\
23,3 \\
10,8\end{array}$ & $\begin{array}{r}9,7 \\
14,2 \\
13,7 \\
12,3 \\
18,7 \\
9,4 \\
14,3 \\
13,6 \\
16,2 \\
23,3 \\
10,0\end{array}$ & $\begin{array}{r}10,3 \\
15,4 \\
14,8 \\
12,4 \\
17,6 \\
9,8 \\
14,9 \\
16,0 \\
16,1 \\
23,3 \\
10,6\end{array}$ & $\begin{array}{r}10,0 \\
15,8 \\
13,6 \\
12,5 \\
17,6 \\
9,8 \\
15,1 \\
16,4 \\
17,0 \\
23,1 \\
11,0\end{array}$ & $\begin{array}{r}10,0 \\
14,5 \\
13,2 \\
12,5 \\
18,1 \\
9,7 \\
14,8 \\
15,1 \\
16,5 \\
23,2 \\
10,7\end{array}$ \\
\hline Totaal & 14,9 & 15,2 & 15,4 & 14,8 & 15,2 & 15,3 & 15,1 \\
\hline
\end{tabular}

Bron: ROA

Het is in tabel 5.8 te zien dat, omdat de verdeling van de uitbreidingsvraag en de vervangingsvraag niet gelijk is over de regio's, de 'volgorde' van de regio's in deze tabel afwijkt van die in de tabellen voor de afzonderlijke vraagcomponenten. Zo kent Noord-Nederland de laagste uitbreidingsvraag, maar tegelijkertijd ook grootste vervangingsvraag. Voor de totale vraag komt deze regio daarmee uit in de buurt van het landelijk gemiddelde. Zo lijkt er ook bij de andere regio's een trend naar het 
gemiddelde te bestaan: er zijn geen duidelijke uitschieters meer aan te wijzen in de tabel. Er zijn eigenlijk maar twee sectoren die een 'uitschieter' kennen. Zo is de totale vraag voor de transportberoepen in Noordwest-Nederland veel groter dan het landelijk gemiddelde, voornamelijk als gevolg van een hoge uitbreidingsvraag. De vraag naar werknemers in de agrarische beroepen in Zuidwest-Nederland is juist hoog als gevolg van een grote vervangingsvraag voor deze beroepen. De vraag naar personeel in de informaticaberoepen in Middenwest-Nederland blijt achter bij het landelijk gemiddelde, vooral als gevolg van een lage uitbreidingsvraag, en een vervangingsvraag die iets onder het landelijk gemiddelde ligt.

Tabel 5.9

Procentuele totale vraag per opleidingssector naar regio, 2001

\begin{tabular}{|c|c|c|c|c|c|c|c|}
\hline \multirow[t]{2}{*}{ Opleidingssector } & \multicolumn{6}{|c|}{ Regio } & \multirow[t]{2}{*}{ Totaal } \\
\hline & $\mathbf{N}$ & 0 & NW & MW & $Z W$ & ZO & \\
\hline Basisonderwijs & 13,3 & 13,6 & 14,2 & 13,6 & 14,2 & 13,6 & 13,7 \\
\hline VMBO theorie & 21,5 & 22,6 & 21,0 & 20,4 & 21,6 & 22,5 & 21,5 \\
\hline VMBO landbouw en techniek & 11,9 & 12,2 & 13,3 & 12,5 & 12,7 & 12,0 & 11,9 \\
\hline VMBO economie & 13,9 & 14,0 & 13,5 & 13,0 & 15,2 & 14,5 & 13,8 \\
\hline VMBO verzorging & 19,9 & 20,8 & 19,4 & 19,6 & 19,2 & 20,9 & 20,1 \\
\hline HAVONWO & 24,2 & 24,8 & 21,7 & 21,5 & 22,8 & 23,7 & 22,7 \\
\hline MBO landbouw en techniek & 12,3 & 12,8 & 13,2 & 13,4 & 12,7 & 12,8 & 12,8 \\
\hline MBO economie & 14,4 & 14,8 & 15,2 & 14,3 & 15,2 & 15,0 & 15,0 \\
\hline $\begin{array}{l}\text { MBO dienstverlening en gezondheids- } \\
\text { zorg }\end{array}$ & 17.0 & 17,5 & 17.6 & 16.8 & 17,3 & 17,4 & 17.0 \\
\hline HBO landbouw en techniek & 12,6 & 12,6 & 12,7 & 11,8 & 12,3 & 12,2 & 11,8 \\
\hline HBO economie & 14,6 & 14,0 & 14,3 & 12,4 & 14,7 & 14,3 & 13,4 \\
\hline HBO onderwijs en sociaal-cultureel & 13,1 & 13,4 & 13,2 & 13,1 & 13,4 & 13,7 & 13,0 \\
\hline HBO paramedisch & 14,5 & 13,0 & 13,0 & 12,7 & 13,0 & 12,6 & 13,1 \\
\hline WO landbouw en techniek & 16,1 & 14,7 & 14,4 & 12,2 & 15,6 & 14,3 & 13,7 \\
\hline WO economie & 19,0 & 17,7 & 15,0 & 14,3 & 15,6 & 16,8 & 15,5 \\
\hline WO letteren en sociaal-cultureel & 14,7 & 14,5 & 14,5 & 13,9 & 15,5 & 15,8 & 15,5 \\
\hline WO medisch & 12,0 & 11,2 & 11,0 & 10,6 & 9,8 & 12,7 & 10,1 \\
\hline Totaal & 14,9 & 15,2 & 15,4 & 14,8 & 15,2 & 15,3 & 15,1 \\
\hline
\end{tabular}

Bron: ROA

In tabel 5.9 is te zien dat er voor de totale vraag per opleidingssector een nog veel sterkere tendens naar het landelijk gemiddelde optreedt. Alleen WO landbouw en techniek en WO economie vallen op omdat de totale vraag in Noord-Nederland erg hoog is. Dit is toe te schrijven aan de hoge uitbreidingsvraag voor deze sectoren. Zoals al in paragraaf 2.4 is gezegd, geven de cijfers een kleine overschatting van de totale vraag voor per opleidingssector, als gevolg van de gehanteerde verdeelmethodiek voor de uitbreidingsvraag. Het is dan ook in de tabel te zien dat voor sommige opleidingssectoren de totale vraag in vrijwel alle regio's hoger ligt dan de landelijke uitbreidingsvraag. Overigens betreft het kleinere afwijkingen dan deze cijfers suggereren: de regio's Noord-Nederland en Oost-Nederland zijn relatief kleine regio's. Als de vraagcijfers voor bijvoorbeeld de sector WO landbouw en techniek voor alle regio's opgeteld en vergeleken worden met de landelijke cijfers is de 'nominale afwijking' maar heel klein. 
Omdat de aanbodcijfers niet betrouwbaar per beroepssector berekend kunnen worden zullen in de komende paragrafen uitsluitend nog prognoses en knelpunten per opleidingssector getoond worden. Daarom is tabel 5.8 de laatste prognosetabel die per beroepssector gepresenteerd wordt.

\subsection{Aanbod per regio}

In deze paragraaf wordt de regionale verbijzondering van het aanbod van arbeidskrachten getoond. Het aanbod bestaat uit drie componenten. De eerste component wordt gevormd door de baanwisselaars. De tweede component van het aanbod wordt gevormd door de groep schoolverlaters, de derde door de potentiële herintreders. Van de eerste component, de baanwisselaars, kunnen we aannemen dat deze voor een groot deel in de regio blijven werken waar ze al werkzaam waren. Zeker voor oudere werknemers die zich al geruime tijd 'gesetteld' hebben in een plaats, lijkt dit geen onredelijke veronderstelling. Dezelfde veronderstelling lijkt ook gerechtvaardigd voor de potentiële herintreders. Zeker als het gaat om relatief laag opgeleide en/of oudere vrouwen zal heel vaak de werkkring van de man de woonplaats van het gezin bepalen. Bij het regionale aanbod van schoolverlaters is de veronderstelling van regionale binding veel lastiger te maken. De plaats waar men zijn opleiding volgt wordt heel vaak bepaald door ofwel de woonplaats van de ouders, dan wel de plaats waar de opleiding zich bevindt. Zeker bij de wat gespecialiseerdere, hogere opleidingen is er sprake van een zekere regionale concentratie. Het is in die gevallen heel moeilijk aan te geven waar men zich aan zal bieden op de arbeidsmarkt.

Zoals in de paragraaf over de methodiek is aangegeven, is er in de huidige prognoses voor gekozen om er van uit te gaan dat de schoolverlaters zich in eerste instantie aanbieden in de regio waar zij hun opleiding gevolgd hebben. Vanwege de relatief grote regio's en de landelijke spreiding van met name de lagere opleidingen, zal deze aanname zeker voor de lager opgeleiden niet zo'n vertekening van de feitelijke situatie opleveren. Zeker niet wanneer bedacht wordt dat de regionale mobiliteit van lager opgeleiden sowieso lager is dan die van hoger opgeleiden. Voor de hogere opleidingen kan deze manier van regionaal verbijzonderen echter wel tot 'vreemde' uitkomsten leiden, die niet noodzakelijkerwijs de feitelijke situatie weerspiegelen.

Omdat het regionaal verbijzonderen van het aanbod per opleiding al niet zonder problemen is, is er van afgezien om dit regionale aanbod vervolgens ook op te splitsen naar aanbod per beroep. De belangrijkste reden hiervoor is dat er in iedere beroepssector zowel hoog- als laagopgeleiden werkzaam zijn. De aanbodcijfers per beroepsgroep zullen dus vrij sterk beïnvloed worden door de manier waarop het aanbod van met name schoolverlaters regionaal verbijzonderd wordt. Het effect van de nu gehanteerde, niet optimale, methode is in de tabellen naar opleidingsniveau tot op zekere hoogte nog traceerbaar. Het effect zou echter niet meer traceerbaar zijn in de tabellen per beroepssector. De betrouwbaarheid van de cijfers is daarmee zo laag geworden dat presentatie geen zin meer heeft. 


\section{Regionaal aanbod van baanwisselaars}

In tabel 5.10 is het aanbod van baanwisselaars per regio gepresenteerd. Net zoals dit het geval was bij de bruto vervangingsvraag per regio (waar de baanwisselaars een deel van zijn), is te zien dat er slechts heel beperkte verschillen verwacht worden tussen de regio's. Alle regio's kennen een aanbod van baanwisselaars dat ongeveer gelijk is aan het landelijk gemiddelde, 6,5\% op jaarbasis. Er zijn daarbinnen geen opleidingssectoren of regio's aan te wijzen die duidelijk afwijken.

Overigens doet zich ook in tabel 5.10 het probleem van de afwijkingen tussen de gemiddelde regionale en de landelijke percentages voor. De oorzaak is ook hier weer dat het rekenmodel - noodgedwongen - in een andere opleidingsclassificatie rekent dan de voor presentatie in de tabellen gebruikte indeling. Het omrekenen van de ene naar de andere classificatie gaat gepaard met afrondfouten, die in de regionale cijfers relatief groter zijn dan in de landelijke cijfers.

Tabel 5.10

Procentuele aanbod van baanwisselaars per opleidingssector naar regio, 2001

\begin{tabular}{|c|c|c|c|c|c|c|c|}
\hline \multirow[t]{2}{*}{ Opleidingssector } & \multicolumn{5}{|c|}{ Regio } & \multicolumn{2}{|c|}{ Totaal } \\
\hline & $N$ & 0 & NW & MW & ZW & ZO & \\
\hline $\begin{array}{l}\text { Basisonderwijs } \\
\text { VMBO theorie } \\
\text { VMBO landbouw en techniek } \\
\text { VMBO economie } \\
\text { VMBO verzorging } \\
\text { HAVONWO } \\
\text { MBO landbouw en techniek } \\
\text { MBO economie } \\
\text { MBO dienstverlening en gezondheidszorg } \\
\text { HBO landbouw en techniek } \\
\text { HBO economie } \\
\text { HBO onderwijs en sociaal-cultureel } \\
\text { HBO paramedisch } \\
\text { WO landbouw en techniek } \\
\text { WO economie } \\
\text { WO letteren en sociaal-cultureel } \\
\text { WO medisch }\end{array}$ & $\begin{array}{l}7,6 \\
7,4 \\
5,5 \\
7,3 \\
7,0 \\
9,1 \\
5,4 \\
7,0 \\
7,2 \\
5,4 \\
6,6 \\
5,5 \\
5,3 \\
4,8 \\
7,7 \\
6,9 \\
5,1\end{array}$ & $\begin{array}{l}7,3 \\
7,8 \\
5,6 \\
6,9 \\
7,0 \\
8,9 \\
5,5 \\
7,0 \\
7,1 \\
5,5 \\
6,1 \\
5,5 \\
4,8 \\
6,0 \\
7,0 \\
6,9 \\
4,6\end{array}$ & $\begin{array}{l}8,2 \\
7,4 \\
5,7 \\
6,7 \\
6,6 \\
8,8 \\
5,2 \\
6,7 \\
6,9 \\
5,5 \\
6,4 \\
5,7 \\
4,8 \\
6,6 \\
8,1 \\
7,9 \\
4,8\end{array}$ & $\begin{array}{l}7,6 \\
7,2 \\
5,5 \\
6,8 \\
6,6 \\
8,6 \\
5,4 \\
6,6 \\
6,7 \\
5,0 \\
5,9 \\
5,6 \\
4,9 \\
6,1 \\
7,5 \\
7,4 \\
3,8\end{array}$ & $\begin{array}{l}7,7 \\
7,4 \\
5,6 \\
7,3 \\
6,5 \\
8,7 \\
5,3 \\
7,0 \\
7,1 \\
5,2 \\
6,4 \\
5,4 \\
4,8 \\
6,6 \\
7,8 \\
6,9 \\
3,6\end{array}$ & $\begin{array}{l}7,4 \\
7,6 \\
5,5 \\
7,2 \\
6,7 \\
8,8 \\
5,3 \\
7,0 \\
7,1 \\
5,4 \\
6,3 \\
5,5 \\
4,6 \\
6,2 \\
7,4 \\
6,7 \\
5,3\end{array}$ & $\begin{array}{l}8,1 \\
7,5 \\
5,6 \\
7,0 \\
6,7 \\
8,7 \\
5,4 \\
6,9 \\
7,0 \\
5,3 \\
6,2 \\
5,5 \\
4,8 \\
6,2 \\
7,7 \\
7,3 \\
4,8\end{array}$ \\
\hline Totaal & 6,5 & 6,4 & 6,6 & 6,4 & 6,4 & 6,4 & 6,5 \\
\hline
\end{tabular}

Bron: ROA

\section{Regionaal aanbod van schoolverlaters}

In tabel 5.11 is de regionale verbijzondering van de schoolverlaters getoond. Het is te zien dat er in deze tabel wel grotere regionale verschillen te zien zijn. Deze verschillen worden veroorzaakt door het aantal scholieren dat in een bepaalde regio staat geregistreerd voor deze opleidingssectoren, maar ook door het aantal werkenden met die opleiding (de percentages worden immers bepaald op basis van 
het aantal werkenden met een bepaalde opleiding). In de laatste regel van de tabel is te zien dat Noord-Nederland een relatief groot aantal schoolverlaters kent. Dit is voor een groot deel toe te schrijven aan het feit dat weliswaar een groot aantal opleidingen in deze regio vertegenwoordigd is maar dat afgestudeerden van deze opleidingen buiten de regio werk vinden. Hierdoor is het aantal schoolverlaters van deze opleidingen ten opzichte van het aantal werkenden hoog. Het meest opvallend hierbij zijn de sectoren $\mathrm{HBO}$ economie en WO economie.

Tabel 5.11

Procentuele instroom van schoolverlaters per opleidingssector naar regio, 2001

\begin{tabular}{|c|c|c|c|c|c|c|c|}
\hline \multirow[t]{2}{*}{ Opleidingssector } & \multicolumn{4}{|c|}{ Regio } & \multicolumn{3}{|c|}{ Totaa } \\
\hline & $\mathrm{N}$ & 0 & NW & MW & $Z W$ & ZO & \\
\hline Basisonderwijs & 5,4 & 4,7 & 4,7 & 5,1 & 3,7 & 4,0 & 5,1 \\
\hline $\begin{array}{l}\text { VMBO theorie } \\
\text { VMBO landbouw en techniek } \\
\text { VMBO economie } \\
\text { VMBO verzorging } \\
\text { HAVONWO } \\
\text { MBO landbouw en techniek } \\
\text { MBO economie } \\
\text { MBO dienstverlening en gezondheidszorg }\end{array}$ & $\begin{array}{r}6,1 \\
3,9 \\
5,6 \\
4,6 \\
10,2 \\
3,8 \\
5,2 \\
5,0\end{array}$ & $\begin{array}{r}5,2 \\
3,3 \\
6,2 \\
4,4 \\
10,5 \\
3,2 \\
4,3 \\
4,6\end{array}$ & $\begin{array}{l}4,5 \\
3,8 \\
7,2 \\
3,7 \\
6,3 \\
3,6 \\
3,8 \\
3,8\end{array}$ & $\begin{array}{l}4,2 \\
3,9 \\
5,5 \\
4,5 \\
7,1 \\
3,1 \\
4,3 \\
3,4\end{array}$ & $\begin{array}{r}5,3 \\
3,8 \\
10,5 \\
2,8 \\
7,7 \\
3,2 \\
4,1 \\
4,2\end{array}$ & $\begin{array}{l}5,4 \\
2,9 \\
5,2 \\
3,4 \\
8,9 \\
2,8 \\
3,3 \\
4,3\end{array}$ & $\begin{array}{l}5,0 \\
3,6 \\
7,0 \\
3,8 \\
8,0 \\
3,3 \\
4,1 \\
4,2\end{array}$ \\
\hline $\begin{array}{l}\text { HBO landbouw en techniek } \\
\text { HBO economie } \\
\text { HBO onderwijs en sociaal-cultureel } \\
\text { HBO paramedisch } \\
\text { WO landbouw en techniek } \\
\text { WO economie } \\
\text { WO letteren en sociaal-cultureel } \\
\text { WO medisch }\end{array}$ & $\begin{array}{r}5,4 \\
10,9 \\
3,9 \\
4,9 \\
5,3 \\
12,8 \\
6,5 \\
4,2\end{array}$ & $\begin{array}{l}4,8 \\
6,2 \\
3,5 \\
3,7 \\
6,7 \\
4,5 \\
5,0 \\
1,8\end{array}$ & $\begin{array}{l}3,3 \\
5,7 \\
2,6 \\
2,9 \\
1,7 \\
3,3 \\
4,2 \\
2,1\end{array}$ & $\begin{array}{l}3,9 \\
5,4 \\
3,0 \\
3,7 \\
5,3 \\
4,4 \\
5,3 \\
2,3\end{array}$ & $\begin{array}{l}3,6 \\
7,0 \\
3,0 \\
2,0 \\
3,4 \\
7,5 \\
5,0 \\
2,3\end{array}$ & $\begin{array}{l}4,0 \\
5,0 \\
2,7 \\
3,1 \\
3,2 \\
4,8 \\
2,6 \\
2,3\end{array}$ & $\begin{array}{l}4,0 \\
6,2 \\
3,0 \\
3,3 \\
4,4 \\
5,2 \\
4,8 \\
2,3\end{array}$ \\
\hline Totaal & 5,2 & 4,5 & 4,0 & 4,2 & 4,3 & 3,8 & 4,3 \\
\hline
\end{tabular}

Bron: ROA

Als gevolg van het feit dat er zich een universiteit in Groningen bevindt, kent deze sector een grote uitstroom van studenten in deze regio. Ook bij andere sectoren zijn verschillen tussen de regio's aan te wijzen. Zo valt het relatief grote aantal schoolverlaters VMBO economie in Zuidwest-Nederland op, net zoals het lage aantal voor deze sector in Zuidoost-Nederland. De sector HAVONWO kent een relatief groot aanbod in Noord- en Oost-Nederland ${ }^{19}$. Een erg laag aanbod kent de sector WO landbouw en techniek in Noordwest-Nederland, terwijl deze sector in OostNederland juist een relatief groot aanbod kent. $\mathrm{Er}$ zijn overigens meer opleidingssectoren waarbij Noordwest-Nederland het kleinste aanbod kent. Dit zal voor een groot deel veroorzaakt worden door het feit dat zich in de regio Amsterdam een zeer grote concentratie van de werkgelegenheid bevindt, waardoor bij gelijke

19. Merk op dat dit niet wil zeggen dat de meeste schoolverlaters voor deze sector in het noorden te vinden zijn! Het grootste nominale aantal voor deze opleiding is te vinden in het westen van het land. 
aantallen schoolverlaters in de regio's de percentages voor Noordwest-Nederland lager uit zullen vallen. Omdat de Universiteit in Maastricht zich vooral richt op de economische, juridische en medische vakken, is het aanbod in de sector WO sociaal-cultureel in Zuidoost-Nederland veel lager dan in de rest van Nederland.

De samenhang tussen individuele opleidingsinstituten en aantallen schoolverlaters geeft direct ook de zwakte van de verdelingsmethodiek aan: studenten uit de sector WO sociaal-cultureel die in Tilburg of Rotterdam gestudeerd hebben, zullen na hun afstuderen ook wel een baan in Zuidoost-Nederland willen accepteren. Er kunnen dus verschillen tussen regio's gesuggereerd worden die er in feite niet, of slechts in beperkte mate zijn. Ook het omgekeerde kan waar zijn: als alle schoolverlaters uit Noord-Nederland en Zuidwest-Nederland bij voorkeur een baan zoeken in Amsterdam zal er in deze regio's een veel groter tekort (of kleiner overschot) zijn dan de tabellen nu suggereren, terwijl in Noordwest-Nederland een aanbod zal zijn dat vele malen groter is dan de cijfers nu aangegeven.

\section{Regionaal aanbod van herintreders}

De laatste component van het aanbod wordt gevormd door de herintreders. Het aantal potentiële herintreders wordt vooral bepaald door het aantal niet-actieven in een regio en hun opleidingsachtergrond. In een regio waar relatief veel inactieven wonen zijn dus veel meer potentiële herintreders te verwachten.

Tabel 5.12

Procentuele aanbod van herintreders per opleidingssector naar regio, 2001

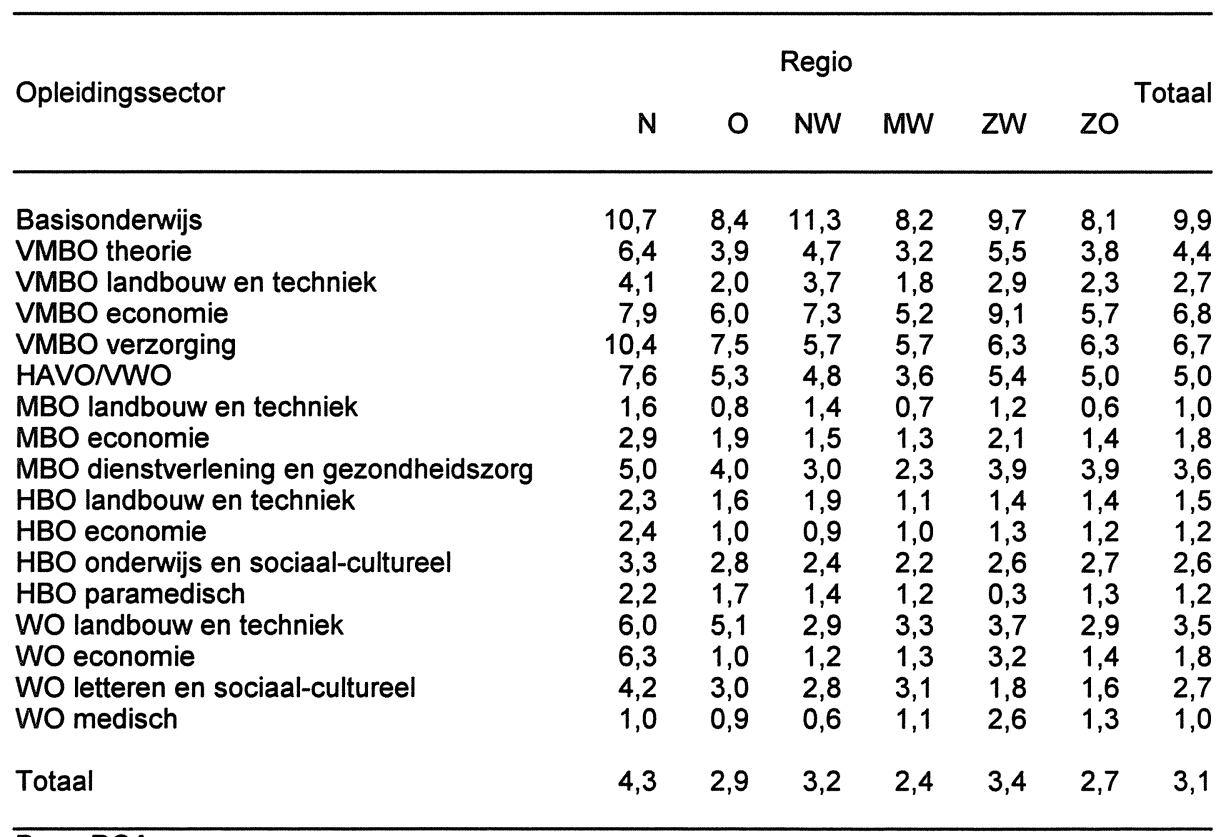

Bron: ROA 
In tabel 5.12 worden de regionale verschillen in aantal herintreders getoond. Uit de tabel is direct te zien dat de verwachte aantallen herintreders grote verschillen laten zien. In Noord-Nederland zijn het er relatief veel, terwijl in Middenwest-Nederland het er relatief weinig zijn. Dit suggereert dat in de regio's waar er al langer sprake is van tekorten op de arbeidsmarkt de 'voorraad' inactieven al behoorlijk aangesproken is, waardoor er in die regio's voornamelijk nog inactieven beschikbaar zijn die gegeven hun kenmerken heel erg weinig kans maken om 'uit zichzelf' er toe over te gaan zich aan te bieden op de arbeidsmarkt. In de regio's met overschotten daarentegen zijn er veel mensen die wel kunnen en willen participeren, maar daarvoor geen kans krijgen. Dit levert dus de relatief hoge aanbodcijfers voor de regio Noord-Nederland op.

Voor het overige laat de tabel weinig opvallende verschillen zien. Hoewel het aanbod van herintreders in Zuidwest-Nederland relatief hoog is, is het verwachte aantal herintreders voor de sector HBO paramedisch erg laag (slechts $0,3 \%$ ). Blijkbaar zijn er in die regio vrijwel geen inactieven die over deze opleidingsachtergrond beschikken, en zijn alle beschikbare arbeidskrachten in deze opleidingssector al ingezet. Dit geeft ook aan dat het vertrouwen op herintreders niet voor alle sectoren in alle regio's een oplossing zal kunnen zijn. Er moeten daarvoor door de werkenden soms grote (regio-overschrijdende) afstanden afgelegd worden: voor de sector HBO paramedisch bevindt zich het grootste procentuele aanbod in Noord-Nederland, maar die mensen zullen niet zo snel overwegen een baan in Zuidoost-Nederland te accepteren. Er zijn dus voor de opleidingssectoren waarvoor deze problemen spelen andere maatregelen nodig. Hierbij valt te denken aan omscholing van andere - in principe minder geschikte - kandidaten, of het actief werven in aangrenzende regio's. Door het actief werven in aangrenzende regio's kan een soort van 'regionaal cascademodel' ontstaan. Dat vereist echter wel dat bemiddelingsinstanties niet alleen goed op de hoogte zijn van wat er in hun eigen regio aan vraag bestaat, maar ook wat er in aangrenzende regio's gevraagd wordt. Anders zou het voor kunnen komen dat een werkzoekende met een bepaalde opleiding de raad krijgt zich om te scholen omdat er in de eigen regio geen werk te vinden is, terwijl er in de aangrenzende regio een tekort aan deze arbeidskrachten bestaat.

\subsection{Knelpunten per regio}

In paragraaf 5.5 werd de totale vraag getoond, in de vorige paragraaf werden de drie aanbodscomponenten getoond. Het is dus nu mogelijk om - voor de opleidingssectoren - vraag en aanbod met elkaar te confronteren. Op die manier kan er inzicht verkregen worden in de knelpunten die naar verwachting in 2001 in de diverse regio's op zullen treden. Hierbij moet natuurlijk wel bedacht worden dat met name de verbijzonderingsmethodiek voor het aanbod per regio's niet optimaal is. In de vorige paragrafen is daar ook al meermaals op gewezen. De gepresenteerde cijfers moeten dan ook als indicatief beschouwd worden, en altijd in samenhang met elkaar en de landelijke cijfers beschouwd worden.

In tabel 5.13 wordt de ISA (Indicator Spanning op de Arbeidsmarkt) gepresenteerd voor de regio's en per opleidingssector. In de laatste kolom staan de landelijke cijfers gepresenteerd, in de laatste regel staat de ISA voor de totale regio. Bij de landelijke 
cijfers wordt geen aandacht besteed aan de regionale mismatch tussen vraag en aanbod: een vraag in Limburg en een aanbod in Groningen die even groot zijn leiden tot een evenwicht op de arbeidsmarkt. De laatste regel in de tabel houdt geen rekening met de kwalitatieve mismatch: zolang vraag en aanbod nominaal even groot zijn is er sprake van een evenwicht. Dit is in zekere zin vergelijkbaar met de cijfers per opleidingssector die ook geen rekening houden met een mismatch binnen de sector: zolang vraag en aanbod binnen de sector even groot zijn is er sprake van een evenwicht. Het is dus zeer goed denkbaar dat er ook in sectoren waar er sprake lijkt van een evenwicht nog grote inspanningen nodig zijn om in voldoende personeel te voorzien.

Tabel 5.13

Indicator Spanning op de Arbeidsmarkt (ISA) per opleidingssector naar regio, 2001

\begin{tabular}{|c|c|c|c|c|c|c|c|}
\hline \multirow[t]{2}{*}{ Opleidingssector } & \multicolumn{6}{|c|}{ Regio } & \multirow[t]{2}{*}{ Totaal } \\
\hline & $\mathrm{N}$ & 0 & NW & MW & ZW & ZO & \\
\hline $\begin{array}{l}\text { Basisonderwijs } \\
\text { VMBO theorie } \\
\text { VMBO landbouw en techniek } \\
\text { VMBO economie } \\
\text { VMBO verzorging } \\
\text { HAVONWO } \\
\text { MBO landbouw en techniek } \\
\text { MBO economie }\end{array}$ & $\begin{array}{l}1,11 \\
0,98 \\
1,02 \\
1,07 \\
1,02 \\
1,03 \\
0,99 \\
1,01\end{array}$ & $\begin{array}{l}1,07 \\
0,94 \\
0,99 \\
1,05 \\
0,98 \\
1,00 \\
0,97 \\
0,98\end{array}$ & $\begin{array}{l}1,11 \\
0,96 \\
1,00 \\
1,08 \\
0,97 \\
0,98 \\
0,97 \\
0,97\end{array}$ & $\begin{array}{l}1,07 \\
0,94 \\
0,99 \\
1,05 \\
0,97 \\
0,98 \\
0,96 \\
0,98\end{array}$ & $\begin{array}{l}1,07 \\
0,97 \\
1,00 \\
1,12 \\
0,96 \\
0,99 \\
0,97 \\
0,98\end{array}$ & $\begin{array}{l}1,06 \\
0,95 \\
0,99 \\
1,04 \\
0,96 \\
0,99 \\
0,96 \\
0,97\end{array}$ & $\begin{array}{l}1,10 \\
0,95 \\
1,00 \\
1,07 \\
0,97 \\
0,99 \\
0,97 \\
0,98\end{array}$ \\
\hline $\begin{array}{l}\text { MBO dienstverlening en gezondheidszor } \\
\text { HBO landbouw en techniek } \\
\text { HBO economie } \\
\text { HBO onderwijs en sociaal-cultureel } \\
\text { HBO paramedisch } \\
\text { WO landbouw en techniek } \\
\text { WO economie } \\
\text { WO letteren en sociaal-cultureel } \\
\text { WO medisch }\end{array}$ & $\begin{array}{l}1,00 \\
1,00 \\
1,05 \\
1,00 \\
0,98 \\
1,00 \\
1,08 \\
1,03 \\
0,98\end{array}$ & $\begin{array}{l}0,98 \\
0,99 \\
0,99 \\
0,98 \\
0,97 \\
1,03 \\
0,95 \\
1,00 \\
0,96\end{array}$ & $\begin{array}{l}0,96 \\
0,98 \\
0,99 \\
0,98 \\
0,96 \\
0,97 \\
0,98 \\
1,00 \\
0,96\end{array}$ & $\begin{array}{l}0,96 \\
0,98 \\
1,00 \\
0,98 \\
0,97 \\
1,02 \\
0,99 \\
1,02 \\
0,97\end{array}$ & $\begin{array}{l}0,98 \\
0,98 \\
1,00 \\
0,98 \\
0,94 \\
0,98 \\
1,03 \\
0,98 \\
0,99\end{array}$ & $\begin{array}{l}0,98 \\
0,99 \\
0,98 \\
0,97 \\
0,96 \\
0,98 \\
0,97 \\
0,95 \\
0,96\end{array}$ & $\begin{array}{l}0,98 \\
0,99 \\
1,00 \\
0,98 \\
0,96 \\
1,00 \\
0,99 \\
0,99 \\
0,98\end{array}$ \\
\hline Totaal & 1,01 & 0,99 & 0,98 & 0,98 & 0,99 & 0,98 & 0,99 \\
\hline
\end{tabular}

Bron: ROA

In tabel 5.13 is te zien dat in alle regio's sprake is van tekorten, met uitzondering van Noord-Nederland, waar een klein overschot is. Dat overschot is echter voor een groot deel toe te schrijven aan het grote overschot in de sector Basisonderwijs, hoewel ook andere sectoren in Noord-Nederland een overschot kennen dat groter is dan in de andere regio's. De regio's Noordwest-, Middenwest- en Zuidoost-Nederland kennen de grootste tekorten. De regionale verschillen vertalen zich in bijna alle opleidingssectoren, net zoals de landelijke verschillen zich voordoen in bijna alle regio's. De enige uitzondering hierop wordt gevormd door de VMBO-opleidingen in Noordwest-Nederland. Deze kennen namelijk grotere overschotten dan het landelijk gemiddelde, terwijl de regio als geheel een groter tekort kent dan het landelijk gemiddelde. In Zuidoost-Nederland lijken de verschillen tussen de opleidingssectoren het kleinste, terwijl in de westelijke gebieden de verschillen veel geprononceerder zijn. 
Het feit dat de meeste regio's hetzelfde beeld vertonen als het landelijk gemiddelde is ten dele een gevolg van de gehanteerde methodiek, waarbij de regionale cijfers afgeleid zijn van de totaalcijfers. Het gevolg daarvan is dat deze regionale cijfers een tendens naar de landelijke cijfers vertonen. De cijfers in deze tabel moeten dan ook in hoge mate als indicatie gebruikt worden waarbij te zien is in welke regio's de tekorten relatief hoog en waar ze relatief laag zijn. De exacte waarde van de ISA is daarbij minder relevant. De exacte waarde van de 'regionale ISA' is ook minder relevant, omdat hij door een aantal afrondfouten in de methodiek beïnvloed wordt. Zo zijn bijvoorbeeld de tekorten in de sector WO medisch in vrijwel alle regio's hoger dan op landelijk niveau, hetgeen vooral te wijten is aan de afrondfouten in de regionale uitbreidingsvraag. Omdat deze fouten wel overal ongeveer even groot zijn, zijn de verschillen tussen de regio's in zekere zin informatiever dan de feitelijke waarde.

Het beschouwen van prognoses voor afzonderlijke regio's hoeft niet altijd tot de juiste interpretatie te leiden. Zo kent Noord-Nederland voor veel richtingen een overschot aan werkzoekenden. Dit leidt al snel tot de conclusie dat in die regio mensen met bv. VMBO landbouw en techniek zich beter om kunnen laten scholen tot VMBO theorie omdat er voor die opleidingssector een regionaal tekort is. Een veel logischer stap zou zijn om die werkzoekenden tot regionale mobiliteit te verleiden, omdat in de regio Oost-Nederland een tekort bestaat aan mensen met een opleiding VMBO landbouw en techniek. Daar waar de eerste oplossing (omscholen) het probleem in één regio vermindert, leidt de tweede oplossing (regio-mobiliteit) tot een oplossing van het probleem in twee regio's!

Ditzelfde geldt in zeer sterke mate voor de opleiding WO economie. In NoordNederland is er een overschot van ongeveer $8 \%$. Dit zou bij het beschouwen van de cijfers van alleen die regio al snel leiden tot het advies aan studenten om vooral een andere richting te kiezen: WO medisch kent tenslotte een tekort. Bij nadere beschouwing blijkt echter dat er voor WO economie landelijk gezien ook een tekort is, weliswaar kleiner dan dat voor WO medisch maar nog steeds aanzienlijk. Het is dus niet gunstig vanuit een landelijke optiek om mensen die graag economie studeren hiervan af te houden. Dat lijkt weliswaar het probleem in Noord-Nederland op te lossen, maar het zal niet bijdragen aan de oplossing van het landelijke probleem. Het zal ook de studenten waarschijnlijk niet gelukkiger maken: die wilden immers graag economie studeren. Het is dus veel beter om te benadrukken dat economie studeren een gunstig perspectief biedt (want er is een landelijk tekort), maar dat als men economie studeert in Groningen men daarna waarschijnlijk in een ander deel van Nederland werk zal moeten zoeken ${ }^{20}$.

20. Dit is natuurlijk wat er al gebeurt, maar deze regionale herverdeling van schoolverlaters was niet in de methodiek op te nemen. Het overschot in Groningen wordt derhalve al overschat. Dit neemt niet weg dat ook nu al geldt dat men elders werk moet zoeken, omdat het in het noorden in onvoldoende mate voorhanden is. 


\subsection{Samenvatting}

Voor een aantal doeleinden zijn landelijke prognoses niet toereikend. De meeste werkgevers werven hun personeel, zeker voor de lagere functies, op de regionale arbeidsmarkt. Zo zoeken ook veel mensen in hun eigen regio naar werk. Ook opereren organisaties als Arbeidsvoorziening in hoge mate regionaal, en hebben dus voor hun scholings- en bemiddelingsprogramma's arbeidsmarktgegevens nodig over hun eigen regio, om op basis daarvan tot adequaat beleid te kunnen komen. De landelijke prognoses geven dan ook niet de informatie waar deze gebruikers behoefte aan hebben. De landelijke cijfers geven namelijk niet aan of er sprake is van een regionale mismatch: ze laten niet zien of vraag en aanbod zich op dezelfde plaats bevinden. Vandaar dat in dit hoofdstuk een regionale verbijzondering van vraag en aanbod gepresenteerd is.

De regionale uitbreidingsvraag is gebaseerd op een regionale verbijzondering van werkgelegenheidscijfers per bedrijfssector. Het blijkt daarbij dat de groei van de meeste regio's gelijk is. Alleen Noord-Nederland blijt iets achter in de groei van de werkgelegenheid. Hoewel in de meeste bedrijfssectoren er in alle regio's sprake is van ofwel groei, ofwel krimp (landbouw), valt de bedrijfssector energie op omdat hier sprake lijkt te zijn van een verschuiving van de werkgelegenheid zonder dat daar een landelijke groei of krimp mee gepaard gaat. In Noord-Nederland groeit deze bedrijfssector met bijna $1 \%$ terwijl in Zuidwest-Nederland er een krimp van $1 \%$ wordt verwacht voor het komende jaar. Op basis van de bedrijfssectorgegevens kunnen prognoses voor de uitbreidingsvraag per beroeps- en per opleidingssector gemaakt worden, net zoals dit voor de landelijke prognoses is gedaan. De diverse beroepssectoren kennen duidelijke verschillen tussen de regio's en tussen de sectoren binnen de regio's. Landelijk gezien kent alleen de beroepssector agrarische beroepen een krimpende werkgelegenheid, alleen Noordwest-Nederland kent deze krimp niet. Sectoren die landelijk gezien groeien blijken dat niet in alle regio's even sterk te doen: de meest opvallende sector is hier technische en industrieberoepen, die landelijk gezien een kleine groei kent, maar in Noord-Nederland juist een kleine krimp. Ook is het niet zo dat in alle regio's dezelfde sector de grootste groeier is: zo zijn de informaticaberoepen in een drietal regio's (Oost-Nederland, ZuidwestNederland en Zuidoost-Nederland) de grootste groeier, terwijl landelijk gezien de sociaal-culturele beroepen de grootste groei doormaken. Tot slot blijkt dat de groei van regio als geheel niet hoeft samen te vallen met de groei van de afzonderlijke sectoren: zo groeien de sociaal-culturele beroepen het hardst in Noord-Nederland terwijl de algehele werkgelegenheidsgroei in deze regio achterblijt bij de rest van Nederland. De uitbreidingsvraag kan ook per opleidingstype bepaald worden. Maar daar waar de regionale prognoses voor de uitbreidingsvraag per beroepssector nog duidelijke afwijkingen van het landelijke patroon laten zien, lijkt dat hier veel minder het geval te zijn. In alle regio's wordt de sector Basisonderwijs geconfronteerd met de grootste krimp, gevolg door het VBMO met een kleine krimp in de werkgelegenheid (met uitzondering van VMBO theorie dat zelfs een bescheiden groei kent). De grootste groei in de werkgelegenheid wordt verwacht in de sector WO economie (NoordNederland, Oost-Nederland, Zuidwest-Nederland en Zuidoost-Nederland) of de sector HBO paramedisch (Noordwest-Nederland en Middenwest-Nederland). 
Naast de uitbreidingsvraag is er sprake van vervangingsvraag. Het blijkt dat - mede als gevolg van het gebruik van het landelijke model - de verschillen in vervangingsvraag tussen de regio's erg klein zijn. Eigenlijk zijn er maar twee regio's die afwijken: Noord-Nederland heeft een bovengemiddelde vervangingsvraag, en Middenwest-Nederland heeft een iets lagere vervangingsvraag. Voor een aantal beroepssectoren zijn de regionale verschillen echter heel klein: er zijn bijna geen regionale verschillen in de medische en paramedische beroepen, en ook in de verzorgende en dienstverlenende beroepen zijn geen regionale verschillen aan te duiden. Ook in de vervangingsvraag per opleidingssector zijn regionale verschillen zichtbaar, hoewel deze niet voor alle sectoren even groot zijn. De sector basisonderwijs kent een kleine spreiding, net zoals de sectoren MBO landbouw en techniek en $M B O$ landbouw en techniek, daarentegen zijn de regionale verschillen voor VMBO economie, HBO paramedisch en WO medisch een stuk groter.

De totale vraag naar arbeidskrachten kent minder regionale verschillen dan de afzonderlijke componenten. Er zijn eigenlijk maar twee sectoren die een 'uitschieter' kennen. Zo is er een hoge totale vraag voor de transportberoepen in NoordwestNederland en voor de agrarische beroepen in Zuidwest-Nederland. $\mathrm{Er}$ is daarentegen een lage totale vraag naar de informaticaberoepen in Middenwest-Nederland. De regionale verschillen in de totale vraag per opleidingssector zijn nog kleiner. Alleen de richtingen WO landbouw en techniek en WO economie vallen op, omdat de totale vraag in Noord-Nederland erg hoog is.

Tegenover de vraag naar personeel staat het aanbod. Op basis van de landelijke cijfers en een verdeelmethodiek over de regio's is een prognose gemaakt van het regionale aanbod per opleidingstype. Ook voor de regionale prognoses wordt dus een onderscheid gemaakt tussen baanwisselaars, schoolverlaters en herintreders. Net zoals dit het geval was bij de bruto vervangingsvraag per regio (waar de baanwisselaars een deel van zijn), blijkt dat er slechts kleine regionale verschillen zijn in het aanbod van baanwisselaars. Alle regio's kennen een aanbod van baanwisselaars dat ongeveer gelijk is aan het landelijk gemiddelde, $6,5 \%$ op jaarbasis. Er zijn daarbinnen geen opleidingssectoren of regio's aan te wijzen die duidelijk afwijken. De regionale verschillen in de verwachte aantallen schoolverlaters zijn groter: vooral Noord-Nederland kent een relatief groot aantal schoolverlaters. Dit is voor een groot deel toe te schrijven aan het feit dat weliswaar een groot aantal opleidingen in deze regio vertegenwoordigd is, maar dat afgestudeerden van deze opleidingen buiten de regio werk vinden. Hierdoor is het aantal schoolverlaters van deze opleidingen ten opzichte van het aantal werkenden in de regio hoog. Het meest opvallend hierbij zijn de sectoren $\mathrm{HBO}$ economie en WO economie. Ook bij andere sectoren zijn verschillen tussen de regio's aan te wijzen. Zo valt het relatief grote aantal schoolverlaters $V M B O$ economie in Zuidwest-Nederland op, net zoals het lage aantal voor deze sector in Zuidoost-Nederland. De sector HAVONWO kent een relatief groot aanbod in Noord- en Oost-Nederland. Een erg laag aanbod kent de sector WO landbouw en techniek in Noordwest-Nederland, terwijl deze sector in Oost-Nederland juist een relatief groot aanbod kent. Tot slot zijn er ook prognoses gemaakt voor de aantallen herintreders per regio. Van de drie componenten laat deze groep grootste regionale 
verschillen zien. In Noord-Nederland zijn het er relatief veel, terwijl in MiddenwestNederland het er relatief weinig zijn. Dit suggereert dat in de regio's waar er al langer sprake is van tekorten op de arbeidsmarkt de 'voorraad' inactieven al behoorlijk aangesproken is, waardoor er in die regio's voornamelijk nog inactieven beschikbaar zijn die gegeven hun kenmerken heel erg weinig kans maken om 'uit zichzelf' er toe over te gaan zich aan te bieden op de arbeidsmarkt. In de regio's met overschotten daarentegen zijn er veel mensen die wel kunnen en willen participeren, maar daarvoor geen kans krijgen. Dit levert dus de relatief hoge aanbodcijfers voor de regio Noord-Nederland op.

Als per opleidingssector en per regio vraag en aanbod met elkaar geconfronteerd worden, blijkt dat er in alle regio's sprake is van tekorten, met uitzondering van de regio Noord-Nederland, waar een klein overschot is. Dat overschot is echter voor een groot deel toe te schrijven aan het grote overschot in de sector Basisonderwijs, hoewel ook andere sectoren in Noord-Nederland een overschot kennen dat groter is dan in de andere regio's. De grootste tekorten doen zich voor in Noordwest-, Middenwest- en Zuidoost-Nederland. De regionale verschillen vertalen zich in bijna alle opleidingssectoren, net zoals de landelijke verschillen zich voordoen in bijna alle regio's. De enige uitzondering hierop wordt gevormd door de VMBO-opleidingen in Noordwest-Nederland. Deze kennen namelijk grotere overschotten dan het landelijk gemiddelde, terwijl de regio als geheel een groter tekort kent dan het landelijk gemiddelde. In Zuidoost-Nederland lijken de verschillen tussen de opleidingen het kleinste, terwijl in de westelijke gebieden de verschillen veel geprononceerder zijn.

Bij de regionale prognoses moet nogmaals gewezen worden op het risico van verkeerde conclusies als de regionale cijfers niet gerelateerd worden aan de landelijke cijfers. Het is mogelijk dat er regio's zijn waar overschotten voor bepaalde opleidingen verwacht worden, terwijl er tegelijkertijd regio's zijn waarvoor er tekorten voor deze opleidingen zijn. Het is onjuist om te constateren dat deze opleiding in deze 'overschotregio' een slecht perspectief heeft en dus valt af te raden. Veel beter zou het zijn om mensen met deze opleiding tot regionale mobiliteit te verleiden. Daar waar omscholen het probleem in slechts één regio vermindert, leidt regiomobiliteit tot een oplossing van het probleem in twee regio's! Pas zodra er voor een bepaalde opleiding zowel een regionaal als een landelijk overschot is, biedt deze opleiding echt geen perspectief. In alle andere gevallen impliceert een keuze voor een dergelijke opleiding een grote noodzaak tot 'regionale mobiliteit' na afronden van de opleiding. Aan de andere kant: als een werkgever in een regio tekorten verwacht voor een zekere opleiding, is het misschien niet de beste strategie om direct mensen met een andere opleidingsachtergrond om te gaan scholen. Het kan best zo zijn dat in een aangrenzende regio wel overschotten, of kleinere tekorten, verwacht worden. In dat geval is het waarschijnlijk veel goedkoper om personeel uit een andere regio te halen. 


\section{Samenvatting en voorstellen voor ontwikkeling}

\subsection{Inleiding}

In dit rapport is een overzicht gegeven van de arbeidsmarktprognoses voor de korte termijn, zoals die dit jaar voor het eerst door het ROA gemaakt zijn. In dit hoofdstuk wordt in paragraaf 6.2 een korte samenvatting gegeven van de voorafgaande hoofdstukken. Omdat dit de eerste keer is dat het ROA een rapport uitbrengt met op een stromenmodel gebaseerde prognoses wordt er daarnaast in dit hoofdstuk uitgebreid stilgestaan bij mogelijke uitbreidingen van de informatievoorziening en mogelijke aanpassingen en uitbreidingen van de gehanteerde methodiek. In paragraaf 6.3 wordt aangegeven op welke punten de huidige informatievoorziening uitgebreid kan worden. Tot slot van dit hoofdstuk wordt in paragraaf 6.4 een aantal suggesties gedaan over de verdere ontwikkelingen die plaats kunnen vinden in het kader van het stromenmodel en de prognosemethodiek.

\subsection{Samenvatting}

\section{Achtergrond van de prognoses}

Als gevolg van veranderende omstandigheden op de arbeidsmarkt is er in toenemende mate belangstelling voor arbeidsmarktprognoses voor de korte termijn. In de ruime arbeidsmarkt van de 80 -er en de eerste helft van de 90 -er jaren hadden de prognoses vooral tot doel om de 'transparantie' van de arbeidsmarkt voor studiekiezers te vergroten. Deze prognoses geven een beeld van de verwachte arbeidsmarktpositie voor schoolverlaters op het moment dat zij hun opleiding afgerond hebben. Dit leidt dus tot de keus van de prognosetermijn van ongeveer vijf jaar (de gemiddelde studieduur). Op het ogenblik is er echter in toenemende mate sprake van een krappe arbeidsmarkt, hetgeen betekent dat vooral de werkgevers problemen hebben of krijgen met het vinden van voldoende goed opgeleid personeel. Het gevolg hiervan is dat men in toenemende mate gaat zoeken onder andere groepen op de arbeidsmarkt dan alleen de schoolverlaters, zoals bijvoorbeeld de werklozen en de herintreders. Om- en bijscholing van dat deel van de (potentiële) beroepsbevolking dat niet onmiddellijk inzetbaar is, kan namelijk een effectief middel zijn om de discrepanties tussen vraag en aanbod, en daarmee de knelpunten in de personeelsvoorziening, te verminderen. Het type scholingsprogramma's dat door bv. de Arbeidsvoorzieningsorganisatie gehanteerd wordt om knelpunten te voorkomen of te verminderen is echter meestal niet gericht op de middellange, maar juist op de korte termijn (dat wil zeggen: één, hooguit twee jaar vooruit).

Tegelijk met de toenemende belangstelling voor de korte termijn is er ook een verschuiving ontstaan in de specifieke informatiebehoefte. De prognoses voor de middellange termijn zijn helemaal gericht op netto ontwikkelingen in vraag en aanbod op de arbeidsmarkt. De informatiebehoefte verschuift echter steeds meer naar de onderliggende bruto bewegingen. Het groeiende bewustzijn dat problemen van vraag en aanbod opgelost zouden kunnen worden door beleid op heel specifieke doel- 
groepen te richten, maakt het noodzakelijk dat er informatie over deze groepen aanwezig is. Voordat namelijk duidelijk is of voor bepaalde beroepen instroombevorderende of uitstroomremmende maatregelen effectief zijn, moet bekend zijn hoe groot de bruto in- en uitstroom voor deze beroepen is. Daarnaast wordt, vanuit het aspect van de voorlichting, loopbaanoriëntatie gericht op werkzoekenden en werkenden steeds belangrijker. Ook dit vereist meer inzicht in de bewegingen op de arbeidsmarkt die gegeven iemands beroep en/of opleiding te verwachten zijn. Met andere woorden, ook vanuit een voorlichtingsperspectief is er behoefte aan een beter inzicht in de bruto stromen op de arbeidsmarkt.

\section{Methodiek}

Er is voor de prognoses voor de korte termijn uitgegaan van een bruto stromenbenadering. Met bruto stromen wordt hierbij bedoeld de optelsom van alle individuele veranderingen op de arbeidsmarkt: daar waar bij de netto-stromenaanpak iemand die zijn baan verlaat gecompenseerd wordt door zijn opvolger (een netto stroom van nul), wordt dus in de huidige aanpak expliciet een uitstroom van 1 en een instroom van 1 onderscheiden. Deze benadering heeft als voordeel dat zowel inzicht verkregen wordt in de bewegingen die plaatsvinden op de arbeidsmarkt, alsook in de mate waarin deze bewegingen afhangen van bv. opleidingsniveau en -richting van de betrokkenen.

De prognoses richten zich op de ontwikkelingen binnen de groep werkenden. Vanuit deze groep vindt uitstroom plaats naar de groep scholieren en de groep nietparticiperenden, er vindt baanmobiliteit plaats binnen de groep werkenden, of men verdwijnt - bv. door pensioen - buiten de potentiële beroepsbevolking. Aan de andere kant vindt er in deze groep instroom plaats, uit de groep scholieren (aangeduid als schoolverlaters), uit de groep niet-participerenden (aangeduid als herintreders), maar ook door baanmobiliteit (aangeduid als baanwisselaars). In deze bruto stromenbenadering is het dus mogelijk om de totale uitstroom op te splitsen in vier groepen, en om de totale instroom op te splitsen in drie groepen. Om zoveel mogelijk aansluiting te zoeken en te vinden bij de prognoses voor de middellange termijn, zijn ook in dit rapport prognoses gegeven voor de uitbreidingsvraag, vervangingsvraag en de arbeidsmarktinstroom. Hierbij moet dus wel bedacht worden dat zowel de vervangingsvraag als de instroom veel breder gedefinieerd zijn dan bij de prognoses voor de middellange termijn. De prognoses voor de uitbreidingsvraag zijn gebaseerd op de werkgelegenheidsprognoses voor bedrijfssectoren van het Centraal Planbureau. Vanwege de nadruk op de korte termijn is hierbij uitgegaan van de arbeidsmarktprognoses voor de korte termijn afkomstig uit het Centraal Economisch Plan 2000. Net zoals bij de arbeidsmarktprognoses voor de middellange termijn zijn ook de arbeidsmarktprognoses voor de korte termijn aangepast voor verschuivingen in de beroepenstructuur binnen de onderscheiden bedrijfssectoren.

De prognoses voor de vervangingsvraag en de instroom van baanwisselaars en herintreders zijn gebaseerd op het stromenmodel dat geschat is op basis van het Sociaal-Economisch Panel (de gegevens over 1994 tot en met 1996) in combinatie met gegevens over de (potentiële) beroepsbevolking uit de EBB (gegevens over 
1997 en 1998). De prognoses voor het aantal schoolverlaters zijn gebaseerd op het schoolverlatersmodel dat ontwikkeld is voor de prognoses voor de middellange termijn. Binnen dit model wordt, op basis van de Referentieramingen van het Ministerie van Onderwijs, Cultuur en Wetenschappen, een prognose gemaakt van de aantallen schoolverlaters die per jaar de arbeidsmarkt betreden. Hierin worden ook de aantallen schoolverlaters uit het niet-initieel onderwijs meegeteld.

De prognoses zijn in eerste instantie opgesteld voor een relatief hoog aggregatieniveau van 11 beroepssectoren en 17 opleidingssectoren, maar daar waar mogelijk zijn de prognoses gegeven voor in totaal 121 beroepsgroepen en 97 opleidingstypen, gespreid over de volle breedte van de arbeidsmarkt. Deze cijfers op laag aggregatieniveau zijn echter niet in dit rapport opgenomen, maar uitsluitend in de bijbehorende Statistische Bijlage. In veel gevallen wordt in dit rapport en de bijbehorende Statistische Bijlage naast een getalsmatige indicatie ook een kwalitatieve typering gegeven van de prognose. Dit vereenvoudigt enerzijds de interpretatie van de cijfers, terwijl het anderzijds de onzekerheidsmarges waarmee het opstellen van prognoses gepaard gaat reduceert.

Door de verwachte vraag- en aanbodstromen met elkaar te confronteren wordt een indicatie verkregen van de knelpunten die op de arbeidsmarkt op zullen gaan treden. Deze knelpunten worden weergegeven door middel van een indicator die de spanning op de arbeidsmarkt weergeeft (ISA: Indicator Spanning op de Arbeidsmarkt). Deze indicator is niet geconstrueerd met het oog op een bepaalde groep (aanbieders of vragers), maar met het oog op de situatie op de arbeidsmarkt als geheel. De indicator geeft aan wat de situatie is op de arbeidsmarkt en de daaruit volgende implicaties voor vragers en aanbieders van arbeid. Als er sprake is van een ruime arbeidsmarkt, betekent dit minder goede perspectieven voor werkzoekenden, maar ook minder knelpunten voor werkgevers. Een krappe arbeidsmarkt daarentegen leidt tot betere perspectieven voor werkzoekenden en een grotere kans op knelpunten voor de werkgevers.

\section{Stromen op de arbeidsmarkt}

Inzicht in de stromen die zich op de arbeidsmarkt voordoen helpt om de prognoses beter te interpreteren, maar geeft ook een idee waar eventuele knelpunten door kunnen ontstaan. Is het een hoge uitstroom van personeel dat een tekort veroorzaakt, of juist een achterblijvend aanbod? En als het een hoge uitstroom is, wat kan dan de oorzaak zijn van die uitstroom? Kennis over deze dynamiek op de arbeidsmarkt kan dus de aanzet vormen tot een meer gerichte analyse van mogelijke oplossingen voor de problemen in de diverse sectoren.

De bruto vervangingsvraag (totale uitstroom) is de eerste stroom die van belang is. Het blijkt dat de uitstroom zeer sterk gerelateerd is aan leeftijd en geslacht van de betrokken werknemers. Jongeren kennen als gevolg van o.a. zoekmobiliteit een hoge uitstroomkans. Naarmate men ouder wordt, wordt de uitstroomkans lager. Pas zodra de VUT of pensioen weer in zicht komen, stijgt de uitstroomkans weer. Daarnaast is er een duidelijk verschil tussen mannen en vrouwen: de uitstroomkans van 
vrouwen is bijna twee keer zo groot als die van mannen. De oorzaak daarvan moet worden gezocht in het zogenaamde 'kinderdal': vrouwen onderbreken hun loopbaan om zich te wijden aan het krijgen en opvoeden van kinderen. Juist in die leeftijdscategorie (35-40 jaar) is het verschil tussen mannen en vrouwen in uitstroomkans het grootst. Behalve een verschil naar leeftijd en geslacht is er ook een verschil in uitstroomkans naar opleidingsniveau. De mobiliteit is het laagste op de laagste opleidingsniveaus. De hogere opleidingsniveaus kennen een hogere uitstroom, waarbij die op het WO-niveau nog iets lager is dan die op het HBO-niveau.

Als men uitstroomt zijn er drie mogelijkheden, ofwel men gaat naar een andere baan (doorstroom), ofwel men wordt niet-actief (werkloos of niet-participerend), ofwel men gaat (terug) naar school. De doorstroom blijkt de belangrijkste bestemming: van de totale uitstroom gaat bijna de helft naar een andere baan, wordt iets meer dan $10 \%$ werkloos, $34 \%$ verlaat de arbeidsmarkt, terwijl ca. $10 \%$ aan een opleiding begint. Deze verhouding is echter in hoge mate gerelateerd aan de kenmerken van de betrokken persoon. Hoe ouder men wordt, des te groter de kans dat men de arbeidsmarkt verlaat. $\mathrm{Er}$ is ook een duidelijk verschil tussen mannen en vrouwen: als zij van arbeidsmarktpositie veranderen gaan mannen veel vaker naar een andere baan, terwijl vrouwen veel vaker de arbeidsmarkt definitief verlaten of zich in ieder geval voor langere tijd terugtrekken van de arbeidsmarkt. Ook blijkt ook hier de opleiding weer een belangrijke factor te zijn: de baanmobiliteit is aanzienlijk hoger voor de hoger opgeleiden, terwijl het percentage laagopgeleiden dat de arbeidsmarkt verlaat relatief hoog is. De uitstroom naar werkloosheid is op alle opleidingsniveaus ongeveer gelijk. Behalve verschillen in het mobiliteitspatroon als gevolg van verschillen in persoonlijke kenmerken zijn er ook vrij grote verschillen in mobiliteit tussen de beroepssectoren. Het is met name het niveau van de uitstroom dat sterk verschilt tussen de beroepssectoren.

In geval van baanmobiliteit blijkt de meerderheid - ongeveer driekwart - een volgende baan binnen de sector te vinden. Jongeren veranderen relatief vaak van sector - waarschijnlijk als gevolg van zoekmobiliteit - terwijl dat op middelbare leeftijd veel minder gebeurt. De oudere baanwisselaars tussen de 40 en de 45 daarentegen veranderen weer relatief vaker van sector. Daarnaast blijkt dat zowel de ongeschoolden als de hoogopgeleiden relatief vaak van sector veranderen, terwijl de niveaus daartussen in driekwart van de gevallen mobiel zijn binnen hun eigen beroepssector. Tot slot lijkt de ene sector veel beter in staat te zijn personeel vast te houden dan de andere. Van de mensen die werkzaam waren in de informaticaberoepen is vrijwel iedereen mobiel binnen de sector. Ook voor de medische en paramedische beroepen, de economisch-administratieve beroepen en de verzorgende en dienstverlenende beroepen blift de grote meerderheid binnen de sector. Deze mensen blijven natuurlijk niet noodzakelijkerwijs in hetzelfde beroep werkzaam: zo kent bijvoorbeeld de zorgsector veel beroepen waarvoor het zeer lastig blijkt om werknemers vast te houden.

Tegenover de uitstroom staat de instroom. De instroom wordt gevormd door drie groepen, de baanwisselaars, de schoolverlaters en de herintreders. De baanwisselaars zijn hierboven als onderdeel van de uitstroom al ter sprake gekomen. De 
schoolverlaters verschillen eigenlijk uitsluitend in opleidingsniveau: het merendeel van de instroom van schoolverlaters wordt gevormd door de schoolverlaters van het MBO en het HBO. Het aantal schoolverlaters dat zich op de arbeidsmarkt aanbiedt met een kwalificatie onder het niveau van de 'startkwalificatie' is nog vrij groot (15\%). Binnen deze groep is zelfs nog een relatief grote groep schoolverlaters met uitsluitend Basisonderwijs. Deze laatste groep moet waarschijnlijk toegeschreven worden aan de uitval in het VMBO en het MBO. Dit hoge aantal wekt enige zorg. Hoewel het in de data niet is na te gaan, is het merendeel van deze ongeschoolde schoolverlaters te wijten aan uitval in de lagere opleidingen. In een tijd waarin gesproken wordt over de startkwalificatie voor alle schoolverlaters, is het bedenkelijk dat het onderwijssysteem er blijkbaar niet in slaagt deze mensen aan een opleiding op VMBO-niveau te helpen. Te vrezen valt dat het aantal drop-outs alleen maar toe zal nemen als de druk op leerlingen om een MBO- in plaats van een VMBO-opleiding te gaan volgen toeneemt. In dat geval zal een actie om meer mensen met een startkwalificatie de arbeidsmarkt te laten betreden averechts uit kunnen pakken, omdat een MBO-opleiding voor een deel van de scholieren eenvoudigweg 'te veel gevraagd is' en ze de school zullen verlaten voordat ze hun opleiding afgerond hebben. Overigens blijkt ook uit de prognoses dat dit probleem zeker niet minder zal worden.

De groep herintreders die instroomt is veel minder homogeen dan de groep schoolverlaters. Er zijn binnen deze groep veel grotere verschillen in leeftijd en opleidingsniveau. Gemiddeld genomen zijn de herintreders aanzienlijk ouder dan de schoolverlaters, en zijn er relatief veel vrouwen in deze groep. Daarnaast blijkt de groep ook vrij laag opgeleid: bijna de helft van de herintreders beschikt niet over een zogenaamde 'startkwalificatie' en is ongeschoold ofwel laag geschoold. Ondanks het feit dat er altijd gezegd wordt dat een dergelijke startkwalificatie noodzakelijk is, is er blijkbaar toch wel ruimte op de arbeidsmarkt voor de mensen die niet over deze kwalificatie beschikken. De vraag is alleen wat voor hen het perspectief op langere termijn is, zeker gegeven de kans op baanverlies voor laaggeschoolden.

Gezien de omvang van de drie groepen kan gesteld worden dat er blijkbaar voor alle drie categorieën ruimte en mogelijkheden zijn op de arbeidsmarkt. Ruim de helft van de instroom bestond uit mensen die al elders werkzaam waren. Omdat deze instroom echter gepaard gaat met een even grote uitstroom, kan door de baanwisselaars nooit een groei van het aantal banen gecreëerd worden. Hiervoor is een instroom van 'nieuwkomers' op de arbeidsmarkt nodig. De totale instroom van 'nieuwkomers' op de arbeidsmarkt bestond voor ongeveer de helft uit schoolverlaters en voor de helft uit herintreders. Voor de vervulling van banen op een laag opleidingsniveau spelen schoolverlaters echter nauwelijks een rol en worden veel baanwisselaars en herintreders aangenomen. De vraag daarbij is natuurlijk of de relatief belangrijke positie van de herintreders hierin het gevolg is van de voorkeuren van de werkgevers, of dat ze 'noodgedwongen' is. Er zijn tal van redenen te bedenken waarom werkgevers de voorkeur geven aan anderen in plaats van aan schoolverlaters. Voor het vervullen van hogere functies zullen ze al snel geneigd zijn om ervaring als selectiecriterium te gebruiken. Daarnaast kan het zo zijn dat ze vacatures op een laag functieniveau hebben, waarvoor een oudere ongeschoolde werknemer voldoende is. De vraag blijft echter in hoeverre de relatief grote instroom 
van oudere relatief laag opgeleide herintreders een gevolg is van de heersende krapte op de arbeidsmarkt.

\section{Landelijke prognoses}

De verwachte uitbreidingsvraag is gebaseerd op de groei per bedrijfssector zoals die door het CPB is gepubliceerd in het CEP. Hiervan kan een uitbreidingsvraag per beroepssector en per opleidingssector worden afgeleid. De totale uitbreidingsvraag is $1,7 \%$. Deze groei is uiteraard niet gelijk verdeeld over de beroepssectoren. De meeste sectoren groeien, maar de agrarische beroepen zullen in 2001 met een half procent krimpen. De grootste groeiers doen zich voor bij de informaticaberoepen en de sociaal-culturele beroepen. Deze twee sectoren zullen het komende jaar groeien met ongeveer $4 \%$.

Ook tussen de opleidingssectoren zijn er verschillen in uitbreidingsvraag. Vanaf MBO-niveau is er sprake van een bovengemiddelde vraag, terwijl daaronder juist een vraag wordt verwacht die lager is dan het gemiddelde. Blijkbaar speelt het proces van upgrading niet alleen op de middellange termijn een rol, maar zijn de effecten hiervan ook op korte termijn goed zichtbaar. Deze verdeling van de vraag naar opleidingsniveau geeft aan dat de geconstateerde mogelijkheden voor lager opgeleiden voornamelijk het gevolg zijn van een hoge vervangingsvraag. Blijkbaar verlaten meer laaggeschoolden de arbeidsmarkt dan nodig is om de gewenste reductie van het aantal laaggeschoolden te bewerkstelligen. Als gevolg van een teruglopende werkgelegenheid voor de lager opgeleiden zal deze vervangingsvraag op termijn afnemen, maar gezien het grote belang van deze groepen op dit moment zal het nog lang duren voor deze opleidingen van de arbeidsmarkt verdwenen zijn. Een andere verklaring voor de relatief hoge instroom van laagopgeleiden in het verleden wordt gevormd door de hoge vraag naar hoger opgeleiden. Voor deze hoger opgeleiden is echter al enige tijd sprake van een krappe arbeidsmarkt. Het zou kunnen zijn dat een deel van de geobserveerde vraag naar lager opgeleiden in feite 'substitutievraag' is, waarbij werkgevers de vacatures - al dan niet met behulp van een cascadeconstructie - vervullen met lager opgeleiden dan dat zij eigenlijk hadden willen hebben. Wanneer dat het geval is, zal de vraag naar lager opgeleiden ook afnemen wanneer het aanbod van hoger opgeleiden (met name op het HBO-niveau) zal toenemen. Beide verklaringen zijn op langere termijn echter 'slecht nieuws' voor de laag opgeleiden.

Naast de uitbreidingsvraag is er ook sprake van een aanzienlijke bruto vervangingsvraag. Landelijk gezien bedraagt deze vervangingsvraag $13,4 \%$ in het jaar 2001 . Ook hier zijn grote verschillen zichtbaar tussen de sectoren: zo kennen de al genoemde medische en paramedische beroepen een erg lage vervangingsvraag van nog geen $8 \%$, terwijl de verzorgende en dienstvertenende beroepen een erg hoge vervangingsvraag kennen van bijna $21 \%$. Ook de transportberoepen vallen op door een hoge vervangingsvraag. Dit is des te opmerkelijker daar deze beide sectoren te maken hebben met vrij grote problemen om voldoende personeel te vinden. Misschien dat een (gedeeltelijke) oplossing gevonden kan worden in het 'zuiniger' omspringen met het eigen personeel. De vervangingsvraag per opleiding kent geen duidelijk patroon: 
er zijn geen duidelijke 'uitschieters', wel is het zo dat er een lichte tendens lijkt te bestaan dat de lagere opleidingsniveaus een relatief hoge uitstroom kennen, de middelbare niveaus een lage uitstroom, en de hogere niveaus weer een hogere uitstroom.

Tegenover de vraag naar staat het aanbod van arbeidskrachten. Dat aanbod bestaat uit drie componenten. De eerste daarvan is het aanbod van baanwisselaars. Het blijkt dan dat een groot deel van de bruto vervangingsvraag geen echte arbeidsmarktuitstroom is: $13,4 \%$ van de werkenden stroomt uit, maar $6,5 \%$ van de werkenden is baanmobiel. De netto uitstroom is dus $6,9 \%$ van het aantal werkenden, aanzienlijk lager dan de bruto uitstroom maar nog steeds een groot aantal. Uitstroom en baanmobiliteit zijn niet onafhankelijk van elkaar: de twee sectoren met de hoogste uitstroom kennen ook de hoogste instroom uit baanmobiliteit: zowel de transportberoepen als de verzorgende en dienstverlenende beroepen kennen een hoge instroom uit baanmobiliteit. Gepresenteerd naar opleidingssector valt op dat zowel de hoge als de lage opleidingsniveaus een relatief hoge baanmobiliteit kennen. De netto uitstroom is echter hoger voor de lagere opleidingsniveaus. Ook dit duidt weer op een relatief $z$ wakke positie van de laagopgeleiden.

Naast de baanwisselaars zijn er ook schoolverlaters die zich als arbeidskrachten aanbieden. De totale instroom van schoolverlaters in 2001 zal ongeveer $4,3 \%$ van het aantal werkenden bedragen. Er wordt een relatief hoge instroom verwacht vanuit studie voor de drie economische opleidingssectoren VMBO economie, HBO economie en WO economie. Ook de algemeen voorbereidende opleidingen VMBO theorie en HAVONWO geven een hoge instroom van schoolverlaters op de arbeidsmarkt te zien. Daarentegen is er relatief weinig instroom vanuit de agrarische en medische opleidingssectoren. Op basis van het stromenmodel kan een inschatting gemaakt worden van de beroepssector waarin de schoolverlaters zich zullen aanbieden. De ene beroepssector blijkt een veel groter aanbod van schoolverlaters te trekken dan de andere. Blijkbaar zijn lang niet alle sectoren even populair bij de schoolverlaters, of zijn er in sommige sectoren nauwelijks mogelijkheden voor schoolverlaters. Zo wordt in de transportberoepen een aantal schoolverlaters verwacht dat slechts $1,5 \%$ van het totaal aantal werkenden in de sector uitmaakt, terwijl dit in de openbare ordeen veiligheidsberoepen ongeveer $9 \%$ is.

De laatste aanbodcomponent wordt gevormd door de herintreders. Er is één beroepssector die opvalt door een zeer hoog aantal herintreders: de sector verzorgende en dienstverlenende beroepen kent een aanbod van 6,4\%. De overige sectoren hebben een veel lager aanbod. Het aanbod van herintreders concentreert zich voornamelijk op de lagere opleidingsniveaus. Vooral Basisonderwijs en VMBO economie kennen een groot aanbod van herintreders. De hogere opleidingsniveaus (HBO en WO) kennen een veel lager aanbod. Dit wordt voornamelijk veroorzaakt door het feit dat er vrijwel geen niet-participerenden zijn met een dergelijk opleidingsniveau.

In totaal is er een verwacht aanbod van herintreders te zien van $3,1 \%$. Dit is lager dan het aanbod uit de baanwisselaars dat $6,5 \%$ bedraagt. Het is ook lager dan het 
aanbod van schoolverlaters dat $4,3 \%$ van het aantal werkenden bedraagt. In het aanbod wordt dus $47 \%$ gevormd door baanwisselaars, $31 \%$ door schoolverlaters, en $22 \%$ door herintreders. Dit laat zien dat het belang van schoolverlaters in het totale aanbod aan het groeien is: over de afgelopen jaren bestond immers bijna $60 \%$ van de instroom uit baanwisselaars, $20 \%$ uit schoolverlaters en $20 \%$ uit herintreders.

Het confronteren van vraag en aanbod levert een indicatie op van de spanning op de arbeidsmarkt. Nog afgezien van een eventuele kwalitatieve mismatch is de totale vraag groter dan het totale aanbod. Dit tekort aan arbeidskrachten doet zich in bijna alle beroepssectoren voor, maar er zijn verschillen. Aan de ene kant zijn er sectoren met een groot tekort zoals de transportberoepen en in mindere mate de verzorgende en dienstverlenende beroepen. In deze twee sectoren zal zich een relatief groot tekort voordoen wat tot (zeer) grote knelpunten in de personeelsvoorziening zal leiden voor de werkgevers. Het directe gevolg hiervan is dat deze sectoren voor werkzoekenden (zeer) goede kansen op werk bieden, mits men natuurlijk over de juiste kwalificaties beschikt. Aan de andere kant blijken er ook sectoren te zijn waar een evenwicht of zelfs een klein overschot aan werkenden verwacht wordt. In de technische en industrieberoepen zijn vraag en aanbod naar verwachting even groot, net zoals in de informaticaberoepen en de beroepssector openbare orde en veiligheid. Voor de medische en paramedische beroepen wordt zelfs een klein overschot verwacht!

De grootste tekorten aan arbeidskrachten doen zich voor op het niveau van MBO en $\mathrm{HBO}$, de tekorten op WO-niveau daarentegen zijn relatief beperkt. Vooral MBO landbouw en techniek en MBO dienstverlening en gezondheidszorg kennen een relatief groot tekort aan arbeidskrachten. Er mag binnen de beroepssector medische en paramedische beroepen dan geen tekort verwacht worden, er is een wel een zeer groot tekort aan mensen met een medische of paramedische opleiding. Ditzelfde geldt ook voor de technische opleidingen op MBO niveau. Dit suggereert dat hoewel het aantal mensen dat zich richt op de diverse beroepssectoren groot genoeg is, zij absoluut niet over de juiste kwalificaties beschikken. $\mathrm{Er}$ is dus sprake van een kwalitatieve mismatch tussen vraag en aanbod: het aanbod is wel van voldoende omvang maar van onvoldoende kwaliteit zijn.

\section{Regionale verbijzonderingen}

Naast de landelijke cijfers is er voor veel gebruikers ook behoefte aan meer regionaal gerichte prognoses. Verschillende bedrijfssectoren zijn niet gelijk verdeeld over de regio's, maar ook blijkt dat werkzoekenden niet altijd even mobiel zijn tussen de regio's. Werkgevers zullen hun personeel in eerste instantie regionaal werven, werkzoekenden zullen zich oriënteren op de regionale arbeidsmarkt. Dit kan er toe leiden dat er op landelijk niveau sprake is van een evenwicht tussen vraag en aanbod, terwijl in feite in een deel van het land sprake is van tekorten, en in een ander deel sprake is van overschotten. Maar ook organisaties als Arbeidsvoorziening hebben hun bezigheden ten aanzien van scholing en bemiddeling regionaal georganiseerd. Vanwege deze behoefte aan regionale informatie wordt in dit rapport een overzicht gegeven van de regionale verbijzonderingen van de landelijke prognoses. 
Hierbij is een indeling in zes regio's gehanteerd, die gebaseerd is op de RBA-indeling van Arbeidsvoorziening. Bij gebruik van zes regio's lijken de data nog van voldoende kwaliteit, is de regionale mobiliteit waarschijnlijk geen grote verstorende factor, en zijn de resultaten nog voldoende regiospecifiek om bruikbaar te zijn. De methodiek die voor de regionale prognoses wordt gebruikt volgt in zeer grote lijnen de methodiek die voor de landelijke prognoses gebruikt wordt.

Het blijkt bij de landelijke prognoses al dat het niet eenvoudig is om aanbodprognoses per beroep te maken. Vandaar dat er van af is gezien om de aanbodcijfers per beroep regionaal te verbijzonderen. Wel is een regionale verbijzondering per beroepssector van de vraagcijfers gemaakt. Vanwege het lage regionale aggregatieniveau was het niet mogelijk om deze cijfers op een betrouwbare manier te desaggregeren over de opleidingstypen en beroepsgroepen. Vandaar dat alle prognoses voor de regio's uitsluitend gegeven zijn op het hoge aggregatieniveau van beroeps- en opleidingssectoren.

De regionale uitbreidingsvraag is gebaseerd op een regionale verbijzondering van werkgelegenheidscijfers per bedrijfssector. Het blijkt daarbij dat de groei van de meeste regio's ongeveer gelijk is. Alleen Noord-Nederland blijft iets achter in de groei van de werkgelegenheid $(1,2 \%)$, terwijl Zuidoost-Nederland de hoogste groei kent met $1,9 \%$. Hoewel in de meeste bedrijfssectoren er in alle regio's sprake is van ofwel groei, ofwel krimp (landbouw), valt de bedrijfssector energie op omdat hier sprake lijkt te zijn van een verschuiving van de werkgelegenheid zonder dat daar een landelijke groei of krimp mee gepaard gaat. In Noord-Nederland groeit deze bedrijfssector met bijna $1 \%$, terwijl in Zuidwest-Nederland er een krimp van $1 \%$ wordt verwacht voor het komende jaar.

Op basis van het landelijke model kunnen ook voor de afzonderlijke regio's de prognoses voor vraag en aanbod opgesteld worden. Het blijkt dat voor vrijwel alle vraagen aanbodcomponenten geldt dat de regionale verschillen beperkt zijn. Afgezien van een aantal uitzonderingen zijn de sectorverschillen in de regio's vergelijkbaar met de landelijke verschillen. Ook is het zo dat per sector de verschillen tussen de regio's vergelijkbaar zijn met de geaggregeerde verschillen tussen de regio's. Dit geldt zowel voor de prognoses per beroeps- als per opleidingssector.

Als per opleidingssector en per regio vraag en aanbod met elkaar geconfronteerd worden, blijkt dat er in alle regio's sprake is van tekorten, met uitzondering van de regio Noord-Nederland, waar een klein overschot is. Dat overschot is echter voor een groot deel toe te schrijven aan het grote overschot in de sector Basisonderwijs, hoewel ook andere sectoren in Noord-Nederland een overschot kennen dat groter is dan in de andere regio's. De grootste tekorten doen zich voor in Noordwest-, Middenwest- en Zuidoost-Nederland. In Zuidoost-Nederland lijken de verschillen tussen de opleidingen het kleinst, terwijl in de westelijke gebieden de verschillen veel geprononceerder zijn.

Bij de regionale prognoses moet er op gewezen worden dat deze niet los van de landelijke cijfers bezien kunnen worden. Het is namelijk mogelijk dat er regio's zijn 
waar overschotten voor bepaalde opleidingen verwacht worden, terwijl er tegelijkertijd regio's zijn waarvoor er tekorten voor deze opleidingen zijn. Het is dus onjuist om te constateren dat deze opleiding in de 'overschotregio' een slecht perspectief biedt en daarom valt af te raden. Veel beter zou het zijn om mensen met deze opleiding tot regionale mobiliteit te verleiden. Daar waar de eerste oplossing (omscholen) het probleem in één regio vermindert, leidt de tweede oplossing (regiomobiliteit) tot een oplossing van het probleem in twee regio's! Pas zodra er voor een bepaalde opleiding zowel een regionaal als een landelijk overschot is, biedt deze opleiding echt geen perspectief. In alle andere gevallen impliceert een keuze voor een dergelijke opleiding een grote noodzaak tot 'regionale mobiliteit' na voltooien van de opleiding. Het is ook voor een werkgever in een regio waar tekorten verwacht voor een zekere opleiding waarschijnlijk niet de beste strategie om mensen met een andere opleidingsachtergrond om te gaan scholen. Het kan best zo zijn dat in een aangrenzende regio wel overschotten, of kleinere tekorten, verwacht worden. In dat geval is het waarschijnlijk veel goedkoper om personeel uit een andere regio te halen.

\subsection{Uitbreiding van de informatievoorziening}

De huidige rapportage beperkt zich voornamelijk tot het laten zien van de verwachte ontwikkelingen en de daar uit voorkomende knelpunten naar opleiding en beroep op de arbeidsmarkt. In hoofdstuk 4 is al betoogd dat dit - met name bij de knelpunten naar beroep - tot vreemde conclusies kan leiden als de gevraagde opleidingsachtergrond en de opleidingsachtergrond van het aanbod niet overeenkomen. $\mathrm{Er}$ is dus eigenlijk per beroepssector behoefte aan een overzicht van vraag en aanbod per opleidingssector. De aanwezige data en het model laten in principe ook het genereren van deze nog gedetailleerdere informatie toe: het model rekent immers met beroep-opleidingscombinaties. Het huidige model is dus in staat, zeker voor de landelijke cijfers op hoog aggregatieniveau, om per beroepssector de knelpunten naar opleidingssector weer te geven. De andere invalshoek is ook mogelijk: het per opleidingssector presenteren van de knelpunten per beroepssector. Voordat dit kan gebeuren is het echter aan te raden om eerst na te gaan in hoeverre deze nog gedetailleerdere informatie betrouwbaar is.

Een tweede uitbreiding op de nu gepresenteerde gegevens is denkbaar op het gebied van de oplossing van knelpunten. Het model geeft prognoses voor verwachte overschotten en tekorten per opleidingssector en beroepssector. Het geeft echter geen informatie over de manier waarop deze knelpunten opgelost kunnen worden, en uit welke doelgroepen werkgevers nog kunnen rekruteren. Deze informatie kan echter wel gegenereerd worden op basis van de beschikbare stroomcijfers. Het is namelijk op basis van deze cijfers bekend welke mensen de afgelopen jaren aangenomen zijn in diverse beroepen en opleidingen. Als deze gegevens beschouwd worden als indicatie van de voorkeuren van werkgevers kunnen ze gebruikt worden om na te gaan of er nog werkzoekenden of niet-actieven zijn die over deze kenmerken beschikken en dus als potentieel kunnen dienen om de knelpunten op te lossen. In feite leidt dat tot een analyse die vergelijkbaar is met die van Borghans e.a. (1998b) maar die behalve met de opleidingsachtergrond van de werkenden ook rekening houdt met de voorkeuren van werkgevers. Dergelijke knelpuntanalyses 
kunnen ook gebruikt worden om informatie te genereren over de behoefte aan scholingsprogramma's. Op basis van bovenstaande gegevens is duidelijk voor welke beroepen er zich knelpunten zullen voordoen, en wat de gevraagde kwalificaties voor deze beroepen zijn. Zodra dit bekend is kan veel gerichter dan nu het geval is bepaald worden welke mensen om-, her- of bijgeschoold kunnen worden om in deze knelpunten te voorzien. Deze gegevens kunnen voor onderwijsinstellingen of de scholingsprogramma's van de Arbeidsvoorzieningsorganisatie van groot belang zijn.

Het is voor werkgevers in een (beroeps)sector niet alleen van belang is om te weten wat de verwachte tekorten zijn, en hoe die eventueel opgelost kunnen worden. Het is daarnaast ook van belang om te weten hoe groot de mobiliteit in een sector is. Dit geeft namelijk aan hoe groot de kans is dat een werkgever met een vacature geconfronteerd gaat worden. Ook is de mate van mobiliteit van belang om de ernst van een tekort in te kunnen schatten. Als er sprake is van een klein tekort en geen baanmobiliteit, heeft een klein deel van de werkgevers te maken met zeer lang openstaande vacatures. Als er in diezelfde situatie echter sprake is van een hoge baanmobiliteit, zal het kleine tekort 'verdeeld' worden over alle werkgevers in de vorm van een aantal kortdurende vacatures. Dit maakt het tekort voor de sector niet kleiner, maar de problemen voor de individuele werkgever wel. Ook zal het zo zijn dat meer baanmobiliteit binnen een sector (i.e. langere vacatureketens) zal leiden tot meer aanpassingsmogelijkheden. Werkgevers kunnen bij meer mobiliteit putten uit een groter aantal potentiële werknemers, terwijl het vacaturebestand waaruit werkzoekenden hun baan moeten zoeken sneller wisselt, zodat zij meer kans maken om een geschikte baan te vinden. Op basis van de verhoudingen tussen bruto uitstroom, doorstroom en instroom kan een indicatie verkregen worden van de mate waarin er interne mobiliteit in beroepssectoren optreedt, hoeveel vacatureketens er optreden, en hoe lang deze gemiddeld zullen zijn.

Wat betreft de regionale arbeidsmarkten is de nu geboden informatie beknopt. De regionale prognoses in dit rapport zijn gemaakt uitgaande van de veronderstelling dat de regionale arbeidsmarkten uitsluitend van elkaar verschillen wat betreft de samenstelling van de beroepsbevolking. In hoofdstuk 5 is echter al aangegeven dat er redenen zijn om te veronderstellen dat er veel meer verschilt tussen de regio's. Het is mogelijk, en misschien wel waarschijnlijk, dat de mobiliteit op de arbeidsmarkt gerelateerd is aan de kenmerken van de locale arbeidsmarkt zoals de samenstelling van de beroepsbevolking, groei van de werkgelegenheid, etc. In dat geval zal het mobiliteitspatroon in de regio's verschillen zelfs als er rekening gehouden wordt met verschillen in leeftijdsopbouw en opleidingsachtergrond. De regionale informatie kan daarom uitgebreid worden met beschrijvende statistieken over de mobiliteit en de daaruit voortvloeiende ontwikkelingen in de afzonderlijke regio's. Daar waar de vorige suggesties uitgevoerd kunnen worden op basis van de nu beschikbare gegevens, vereist dit punt echter dat er meer individuele gegevens op regionaal niveau beschikbaar komen.

Een laatste suggestie met betrekking tot de presentatie van de resultaten is dat het mogelijk is om het rapport aan te vullen met een thematisch hoofdstuk. Dit wordt ook in De arbeidsmarkt naar opleiding en beroep gedaan. De voordelen van een dergelijk 
thematisch hoofdstuk zijn duidelijk. Er zijn veel aspecten van de arbeidsmarkt die binnen de context van het bruto-stromenmodel geanalyseerd kunnen worden. Het opnemen van een themahoofdstuk geeft de mogelijkheid om naast de vaste kern van informatie die in iedere rapportage opgenomen is een aantal van deze aspecten nader te belichten. In een aantal gevallen kunnen de bevindingen welke zijn opgedaan bij het samenstellen van een themahoofdstuk in de volgende versies van het rapport opgenomen worden. Op die manier kan het opnemen van themahoofdstukken ook bijdragen aan een stapsgewijze ontwikkeling van de methodiek en de rapportage. Als onderwerpen voor een themahoofdstuk kan gedacht worden aan zaken die de mobiliteit op de arbeidsmarkt beïnvloeden zoals de effecten van beloningsverschillen tussen sectoren, de effecten van vergrijzing van de beroepsbevolking, maar ook aspecten van werkdruk en carrièremogelijkheden. Daarnaast leent een themahoofdstuk zich ook zeer goed tot het nader bestuderen van arbeidsmarkt in de diverse regio's, omdat het de mogelijkheid biedt om zonder direct voor alle regio's resultaten te geven, wel na te gaan in hoeverre er sprake is van gescheiden regionale arbeidsmarkten.

\subsection{Suggesties voor een verdere ontwikkeling}

Tot slot van dit hoofdstuk worden in deze paragraaf een aantal suggesties gedaan om de kwaliteit van de prognoses na te gaan, en daar waar mogelijk te verbeteren. Zoals altijd bij prognoses zal het noodzakelijk zijn om de kwaliteit van deze prognoses te evalueren op het moment dat de daartoe benodigde data beschikbaar zijn. Op basis daarvan kan dan nagegaan worden op welke punten het model onvoldoende verklaringskracht biedt voor de ontwikkelingen. Bijstelling van het model zal dan in de toekomst tot betere prognoses kunnen leiden.

Maar niet alleen een evaluatie kan tot betere prognoses leiden, ook zonder evaluatie is al een aantal punten aan te geven waarop de methodiek aangepast kan worden. Mobiliteit van werkenden is waarschijnlijk zeer sterk gekoppeld aan de situatie op de arbeidsmarkt: hoe meer mogelijkheden tot mobiliteit, des te groter de mobiliteit zal zijn. Het huidige model kent zo'n interactie tussen de huidige en/of verwachte arbeidsmarktsituatie echter niet. Het modelleren van een dergelijk samenhang vergt echter data over een langere periode. Door omstandigheden konden nu echter slechts drie jaargangen van het Sociaal-Economisch Panel gebruikt worden, en dat was te weinig om dynamische effecten te modelleren. Het in de toekomst gebruiken van langere tijdreeksen zal het steeds beter mogelijk maken om ook dynamische effecten en de samenhang tussen economische ontwikkelingen en de mobiliteit te modelleren.

Overigens is niet alleen de mobiliteit van werkenden gekoppeld aan conjuncturele ontwikkelingen. Ook de schoolkeuze die scholieren maken is voor een deel gerelateerd aan arbeidsmarktfactoren. De schoolkeuze die men na de basisschool maakt, zal voor een zeer groot deel gebaseerd zijn op iemands capaciteiten. De keuze voor het niveau is daarmee dus ook voor een groot deel exogeen bepaald. Echter, de initiële keuze die men maakt wat betreft de opleidingsrichting, zal voor een deel gebaseerd zijn op endogene factoren. Behalve individuele voorkeuren (die 
exogeen bepaald zijn), zullen 'studiekiezers' zich laten leiden door huidige of verwachte arbeidsmarktperspectieven voor de verschillende opleidingen. Borghans e.a. (1996) laten zien dat zowel baankansen als verwacht inkomen een effect hebben op de studiekeuze. Het opnemen van dergelijke terugkoppelingen in het model kan de kwaliteit van de prognoses van de instroom van schoolverlaters verbeteren.

Daarnaast zijn de prognoses waarschijnlijk te verbeteren door het beter op elkaar afstemmen van de gebruikte data. Met name de gehanteerde opleidingsclassificatie heeft voor problemen gezorgd. De ROA-indeling is gebaseerd op een 5-cijferige SOIindeling, terwijl het gebruikte micro-bestand (SEP) het opleidingsniveau slechts op een 3-cijferig niveau registreert. Dit heeft op een aantal punten tot extra onnauwkeurigheden in het model geleid. Het was nu ook onmogelijk om gebruik te maken van regionale informatie in het gebruikte micro-bestand. $\mathrm{Er}$ was derhalve geen mogelijkheid om regionale verschillen in mobiliteitspatronen te modelleren en te gebruiken voor de regionale verbijzonderingen van de prognoses. Beide problemen zouden uitsluitend opgelost kunnen worden door een nauwere samenwerking met het CBS die de leverancier van de data voor deze prognoses is.

Ook bij de regionale prognoses is waarschijnlijk nog winst te behalen. Er spelen hier twee afzonderlijke aspecten. Enerzijds geldt dat binnen de huidige methodiek vooral de inbedding van de regionale prognoses in de landelijke prognoses nog aandacht vraagt. Er zijn hierbij twee problemen geconstateerd die opgelost moeten worden. Ten eerste bleek het vanwege de problemen om de landelijke aanbodcijfers per beroepssector te bepalen niet mogelijk om dit ook betrouwbaar op regionaal niveau te doen. Ten tweede zijn - voornamelijk door afrondfouten - de landelijke en de regionale cijfers nu nog niet overal consistent. De grootste winst op dit laatste punt valt te behalen als aan het bovengenoemde dataprobleem ten aanzien van de opleidingen tegemoet gekomen kan worden. Anderzijds geldt dat de huidige methodiek misschien fundamenteler aangepast moet worden vanwege het feit dat er sprake is van regionale arbeidsmarkten die niet met een model beschreven kunnen worden. In de vorige paragraaf is al gesuggereerd om in een volgend rapport een themahoofdstuk te wijden aan de regionale arbeidsmarkten. Als daaruit blijkt dat er inderdaad sprake is van grote regionale verschillen in mobiliteitsgedrag, zal dit moeten leiden tot aanpassingen van de methodiek teneinde tot betere regionale prognoses te komen. Het punt van de consistentie tussen de landelijke en de regionale prognoses wordt daarmee zeker niet onbelangrijker.

Een laatste punt van aandacht is dat van de samenhang tussen de informatie over de korte en de lange termijn. Dit punt is minder van belang voor de kwaliteit van de prognoses, maar veel meer voor de gebruikers die zowel de prognoses voor de korte als de middellange termijn gebruiken. De in dit rapport gepresenteerde prognoses geven aan bij welke beroepen en opleidingen op korte termijn een tekort zal ontstaan. De noodzakelijke maatregelen zullen in een aantal gevallen echter langer duren dan de termijn waarop het tekort zal ontstaan. De feitelijke duur van de verschillende niet-initiële scholingsactiviteiten varieert van slechts enkele weken tot zelfs veel langer dan een jaar. In dat laatste geval is de vraag in hoeverre de ontwikkelingen die op middellange termijn plaatsvinden in de prognoses voor de 
korte termijn moeten worden verdisconteerd. Het probleem dat zich hierbij voordoet is dat de prognoses voor de middellange termijn gebaseerd zijn op andere CPBaannamen dan die gehanteerd zijn voor de prognoses voor de korte termijn. Dit maakt de beide prognoses ten ene male onvergelijkbaar. Maar eigenlijk is dit vanuit het boven genoemde probleem van de gebruiker ongewenst. De vraag is echter hoe dit probleem op te lossen is: het niet gebruiken van nieuwe informatie bij het samenstellen van de prognoses is zeker geen optie!

Het model heeft de potentie om uit te groeien tot een betrouwbaar prognose-instrument, naast de modellen die nu al door het ROA gehanteerd worden. Het is zelfs denkbaar dat het model verder uitgewerkt wordt zodanig dat er - eenvoudige beleidssimulaties mee uitgevoerd kunnen worden. Voordat het echter zo ver is, zullen er eerst een aantal van de bovenstaande uitbreidingen en aanpassingen plaats gehad moeten hebben! 


\section{Literatuur}

Arbeidsvoorziening (2000), 'Regionale arbeidsmarktprognoses 2000-2005', Zoetermeer.

Borghans, L., A. de Grip, H. Heijke (1996), Labour Market Information and the Choice of Vocational Specialization, Economics of Education Review, Vol. 15, no. 1, pp. 59-74.

Borghans, L., F. Cörvers, M. de Steur, J.D. Vlasblom, H. Vermeulen, K. de Vos, J. Weltevrede (1998), Stromen op de arbeidsmarkt in de Zorgsector, OSA-rapport, Den Haag.

Borghans, L., J. Delmee, P. Marey, J.D. Vlasblom (1998), Toekomstverkenning Arbeidsmarkt en scholing tot 2007, Ministerie van Sociale Zaken en Werkgelegenheid, Den Haag.

Centraal Planbureau (2000), Centraal Economisch Plan 2000, Sdu Uitgevers, Den Haag.

Diephuis, B.J., H. Heijke, J.D. Vlasblom (te verschijnen), Determinants of labour market outflow and occupational mobility, a study on Dutch micro-data, Mimeo.

Eijs, P. van, A. de Grip (1998), De ontwikkeling van het project onderwijs en arbeidsmarkt 19861998, ROA-W-1998/7, Maastricht.

Grip, A. de (1993), Regionaal Arbeidsmarkt Informatie Systeem Limburg. Een verkennende analyse, ROA-R-1993/6, Maastricht.

Grip, A. de, A. Jacobs, J.D. Vlasblom (1999), De inzet van niet-direct inzetbaar arbeidsaanbod bij knelpunten op de arbeidsmarkt, ROA-W-1999/2, Maastricht

Grip, A. de, J.D. Vlasblom (1999), Toekomstverkenning arbeidsmarkt apothekersassistenten in de openbare apotheek, ROA-R-1999/7, Maastricht.

Hofman, W.H.A., A.F.M. Nieuwenhuis, R.J. in 't Veld (1991), 'Het cascademodel: scholing als werkbare oplossing voor marktimperfecties tussen vraag en aanbod', Tijdschrift voor Arbeidsvraagstukken, vol. 7, pp. 30-40.

Maddala, G.S. (1983), Limited and Dependent Variables in Econometrics, Cambridge.

Researchcentrum voor Onderwijs en Arbeidsmarkt, (1997), De Arbeidsmarkt naar Opleiding en Beroep tot 2002, ROA-R-1997/7, Maastricht.

Researchcentrum voor Onderwijs en Arbeidsmarkt (1999a), De Arbeidsmarkt naar Opleiding en Beroep tot 2004, ROA-R-1999/8, Maastricht.

Researchcentrum voor Onderwijs en Arbeidsmarkt (1999b), De Arbeidsmarkt naar Opleiding en Beroep tot 2004, Statistische Bijlage, ROA-R-1999/8B, Maastricht.

Researchcentrum voor Onderwijs en Arbeidsmarkt (2000), Werkgelegenheid en scholing 1999, ROA-R-2000/5, Maastricht.

Vlasblom, J.D., B.J. Diephuis (2000), Methodiek voor korte-termijn arbeidsmarktprognoses op basis van een stromenmodel, ROA-W-2000/4, Maastricht.

Wieling, M.H., A. de Grip., E.J.T.A. Willems (1990), Een systematische kwalitatieve typering van arbeidsmarktinformatie, ROA-W-1990/8, Maastricht.

Willems, E., L. Borghans, A. de Grip (1997) Exit or no entry: replacement demand and shrinking employment, paper gepresenteerd op EALE 1997, Aarhus. 
